Historic, Archive Document

Do not assume content reflects current scientific knowledge, policies, or practices. 

62.09

TMDEX 5:

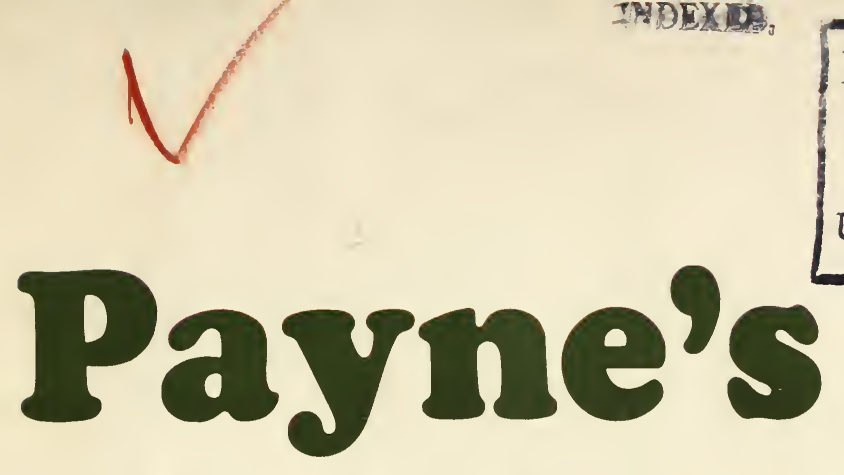

Garden Guide

\section{Seeds, Plants and Trees}

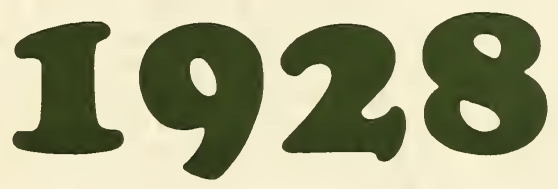

25th Annual Catalog of Seeds. Plants Shrubs - Trees with cultural directions for the planting and care

LIB F A R 8 Rechervan * FEB 111928 * U. S. Dopurtent of Actoritore.

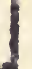




\section{Observe when Ordering Seeds}

All prices quoted on flower, tree, palm and vegetable seeds are postpaid anywhere in the United States, unless otherwise noted. Add $14 \mathrm{c}$ per pound for foreign orders.

\section{Plants and Bare Root Stock}

All prices quoted on Roses, Flowering Plants, Small Fruits, Grape Vines and Hedge or Border Plants do not include postage or express. If requested sent via parcel post, add packing charge of $15 \%$ of the total of the order and also add postage as follows:

Within 150 miles of Los Angeles add $5 c$ to every dollar of your purchase Within 600 miles of Los Angeles add 10c to every dollar of your purchase Within 1800 miles of Los Angeles add 15c to every dollar of your purchase Over 1800 miles of Los Angeles add 20c to every dollar of your purchase NOTE-1t is impractical to give definite information on parcel post rates. The above rates
will cover most orders; charges or refunds will be made in exceptional cases.

If requested sent by express, add packing charge only. We advise express shipments on bare root stock whenever possible. We do not ship plant orders of less than one dollar.

\section{Trees and Shrubs}

All prices quoted on Deciduous and Citrus Fruit Trees, Ornamental Trees, Shrubs and Vines are F.O.B. Los Angeles, and can be sent only by express or freight. Add $15 \%$ of the total amount of the order for packing charges. Minimum packing charge $25 \mathrm{c}$.

\section{Terms of Sale}

All orders must be accompanied with cash or satisfactory references. Remit all money by post office or express money order, bank draft or check, and small sums by registered letter. Postage stamps accepted in amounts up to one dollar.

All prices are subject to change without notice, and all orders accepted subject to prior sale.

Theodore Payne gives no warranty, express or implied, as to the purity, description, quality, productiveness or any other matter of any seeds, bulbs, plants or trees he sells and will not be in any way responsible for the crop.

Address all correspondence to

\section{TheOdoRe Payne \\ 345 South Main Street \\ Los Angeles, Cal.}

Twenty five years of responsibility in back of each order 


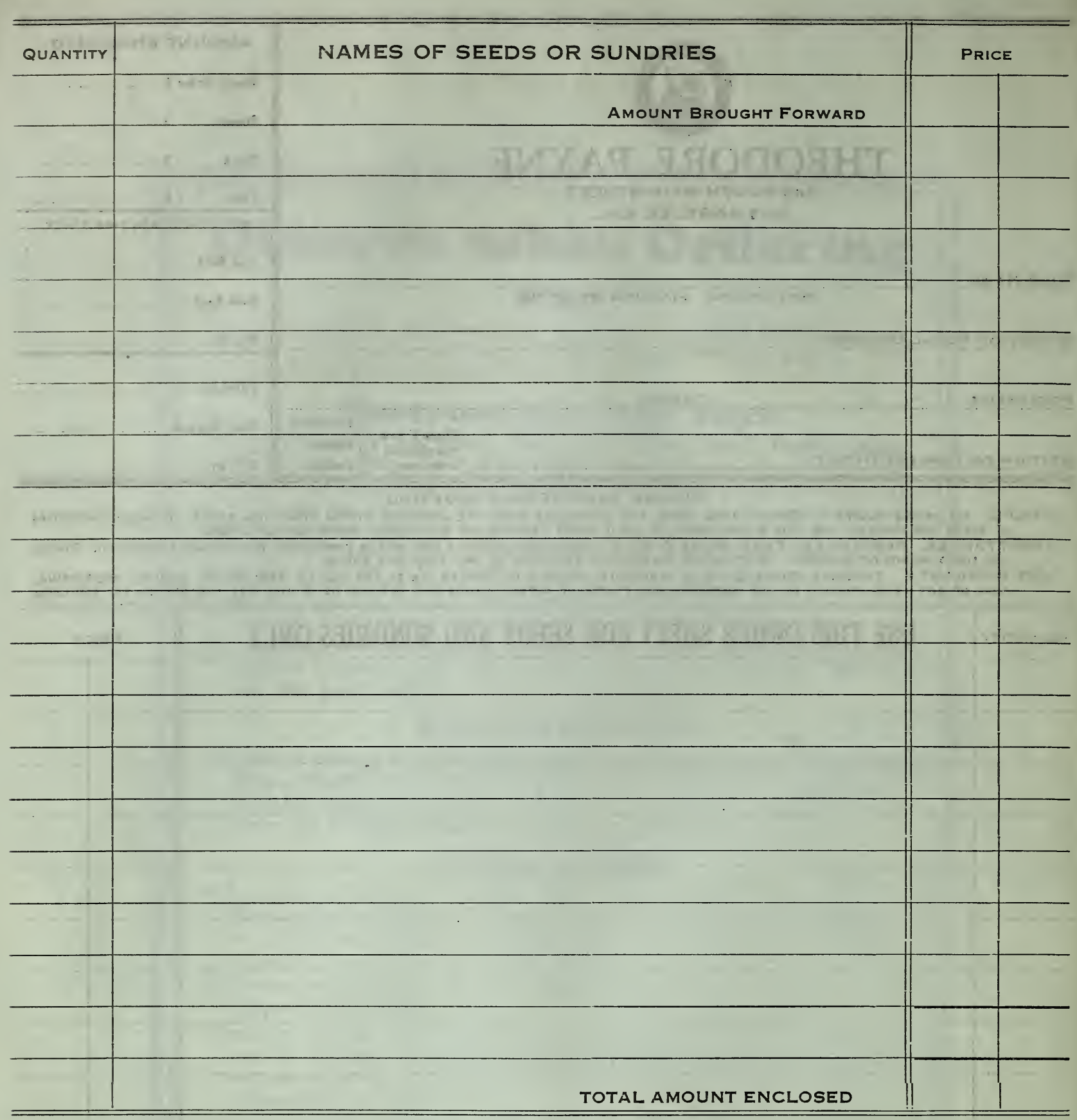

We would consider it a great favor if you would give us the names and addresses of your friends whom you think would be interested in receiving a copy of our catalog. 


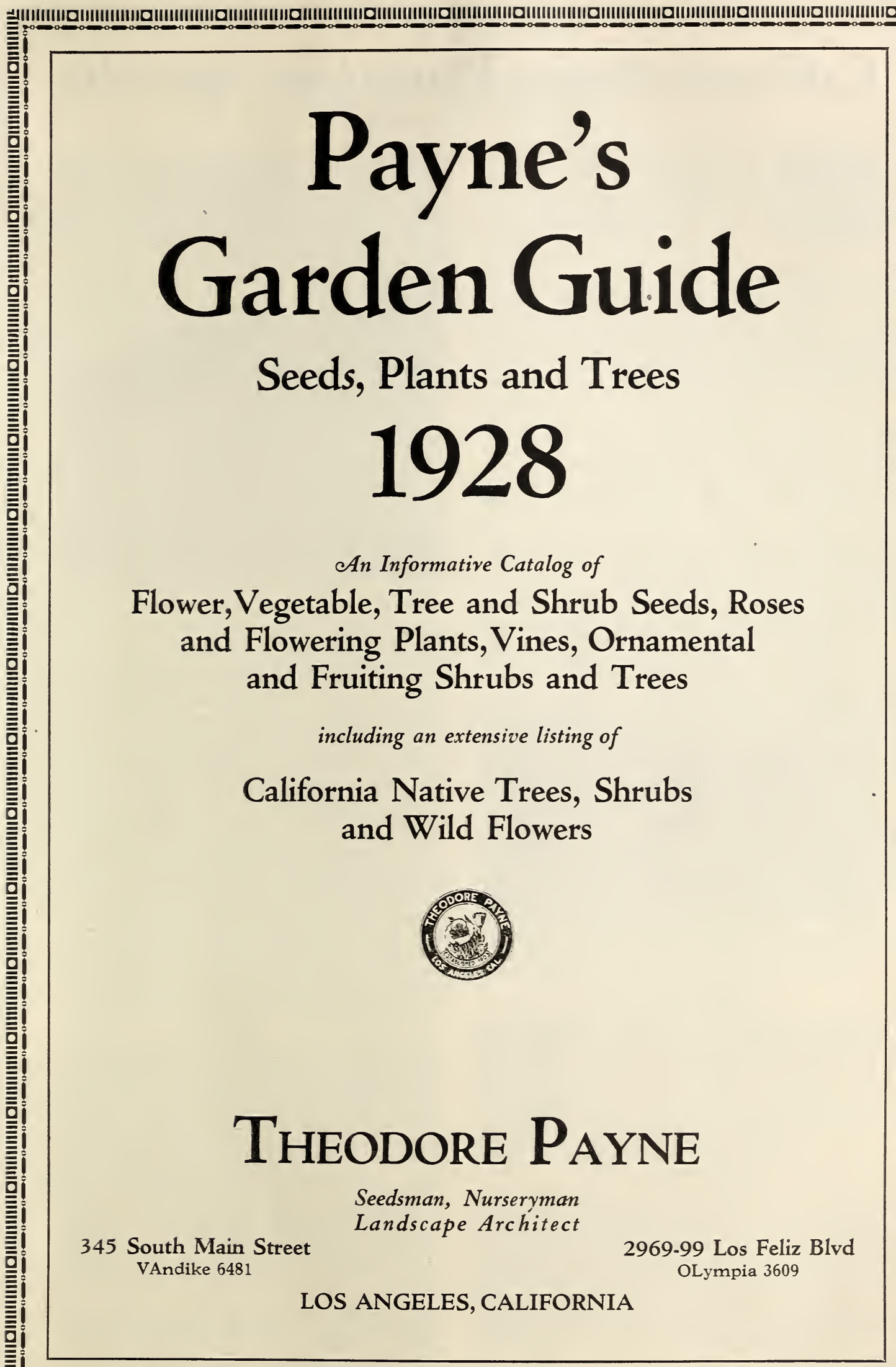




\section{California Native Plants Our Specialty \\ SEE DESCRIPTIONS ON PAGES 47 TO 52}

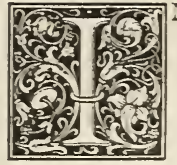

considering the native plants of California one is liable to be prejudiced by reason of associating the native vegetation as seen in the wild with what one may expect in the garden. It must be lemembered that every plant is a native of somewhere and many of the most commonly used and admired are the mult of many years of isolation from their native environment, and that it is only within this past thirty year's that any attempt was made to isolate and scientifically propagate the native plants of Califormia. A native plant in its native environment and one that has been isolated and scientifically propagated are two distinct and hardly comparable plants, whether their nativity be China, South Africa or California. It must be leadily conceded that California has a generous share of the world's plants that she can call hel own and the major portion of their development for use in domestic gardens has come about within the last ten years. A comparison of a native plant in its native environment with one of nursery origin will prove en lightening and very gratifying.

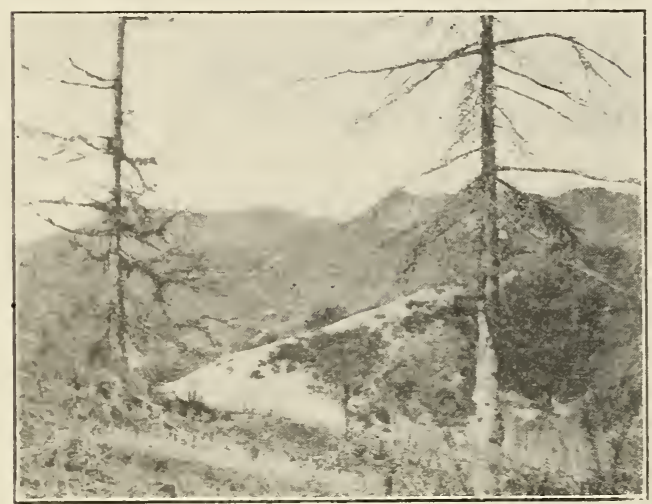

The use of native trees in hillside planting eliminates the possibility fictured in the illustration. They not only live but thrive under these rigorous conditions.

\section{The Hillside Garden}

In the planning of an attractive hillside gar den there are a few important considerations to be met that decide the success or failure of the ultimate effect. As a choice among the many different methods of treatment the use of California native trees, shrubbery and flowers should be the basis of all operations, as they meet the severe conditions imposed and enable the creation of a garden that combines the three essential points of beauty adaptability and economy in maintenance.

The use of the "soft" or exotic group of plants leads in most instances to disappointment, as they are little suited for the rigorous conditions to be met and they place the owner in the uncomfortable position of caring for a fanily of invalid plants. The exotic or imported species will live under average hillside conditions but they have an unhappy existence both for themselves and for their owner. An unhappy plant is neither a thriving one nor is it beautiful-yet one does not like to throw away a living thing, hence the hillside garden oftell presents a bedraggled, appearance and places the owner in an unpleasant and unprofitable position of perpetually nursing a collection of hopeless invalids.

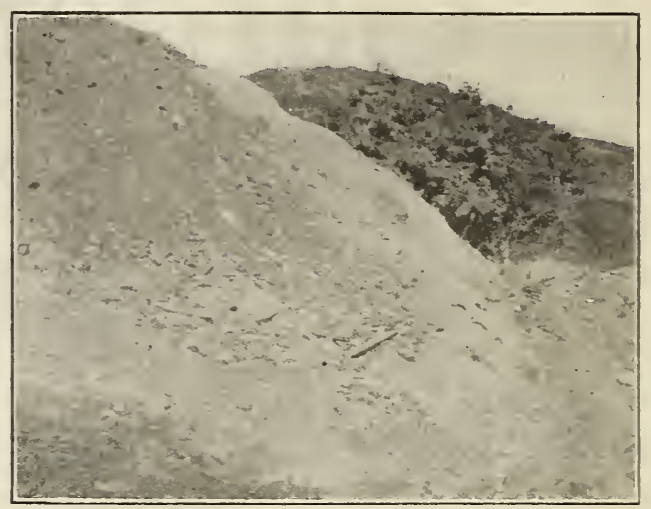

Baren slopes can be made most attractive by pianting in harmony with existing growth, adding just enough color to relieve monotcny.

It is true that, in the making of a hillside garden, a degree of success may be realized with the exotic or imported group of plants by general application of top soil from the lowlands. It is equally true that some of the hardier species of exotic plants will do well in certain portions of the hillside garden, and with these a happy combination of native and exotic can be secured if so desired. The hillside garden planted entirely to native species is not only possible but very practical, as any type of foliage, color of flower or habit of growth can be affected with equal attraction in comparison to the exotic group. The ideal arrangement is secured by the use of native plants in the poor soil or abrupt contour areas and the exotic species in the protected areas that can be easily reached and cared for. thereby enabling the gratification of individual preference for certain plants or flowers without disappointment in growth or appearance.

In the treatment of bare slopes in arid sections and the covering of slides or steep banks caused by the energetic steam shovel the native shrubbery and creepers constitute the only practical remedy. They are impervious to soil conditions, thriving in sand, shale or adobe with equal vigor and requiring neithel water or care after becoming established. They blend with existing natural growth. corering in complete harmony in a few short months an area which would require years of natural growth. Features in color of foliage and flower are easily obtained to suit individual taste; hillsides, ravines or open areas whose natural growth lacks color or perspective can be interplanted with very pleasing lesult; bare fields can be transformed into beauty spots by sowing California wild flower seeds - all with a minimum of initial expense and practically with no maintenance cost. 


\section{GARDEN CALENDAR}

\section{JANUA R I}

Flower Garden.- lf the ground has not been worked over this season, spread a good thick dressing of stable manure over the surface, and dig as deeply as possible. Sow acroclinium, alyssum, antirrhinum, cal endula, calliopsis, candytuft, centaurea, annual chrysanthemum, clarkia, collinsia, cosmos, eschscholtzia, gallardia, larkspur, linum, lupinus, mlgnonette, nemophila, nigella, poppies and sweet peas. Continue to plant narcissus, jonquils, a nemones, ranunculus, German Iris, Japanese iris, Lilium auratum. L. speciosum and L. humboldtil, also calla lilies, gladiolus, amaryllis, agapanthus, lily-of-the-valley, spiraea and dielytra. been worked over this season, spread a good thick been worked over this season, spread a good thick
dressing of stable manure, and dig deeply, working the dressing of stable manure, and dig deeply, working the surface down finely with a rake. Sow beet, early cabkohl rab1, leek, lettuce, mustard, onion, parsley, parsnip, peas, radishes, spinach and turnip. Prepare hot beds and sow peppers and tomatoes. Plant potatoes, asparagus, horseradish and rhubarb roots also cabbage plants.

\section{FEBRUARY}

Flower Garden.-This is a good month to plant roses and all kinds of ornamental trees and shrubs. Sow acroclinium, alyssum, antirrhinum, calendula, calliopsis, cosmos, eschscholtzia, gallardia, larkspur, linum, lupinus, mignonette, nemophila, nigella, popples and sweet peas, in the open ground; also balsam, begonla, gloxinia, lobelia, pyrethrum, scabiosa, verbena. petunia and salvia in seed pans or boxes for transplanting and salvia in seed pans or boxes for transplanting man iris, fapanese iris, Lilium auratum and L. speciman iris, Japanese iris, Lilium auratum and L. specicaladium, gloxinia and tuberose.

Fruit Trees.-All deciduous fruit trees can be planted this month.

Vegetable Garden.-Sow beet, early cabbage, carrot, corn salad, cress, dandelion, endive, kale, kohl rabi, leek, lettuce, mustard, onion, parsley, parsnip, peas, radish, rhubarb, salsify, spinach, turnip, also egg plant, peppers and tomatoes on hot beds. Plant potatoes, asparagus, horseradish and rhubarb roots and cabbage plants.

\section{MARCF}

Flower Garden.-Continue to plant roses and ornamental trees and shrubs. Hardy annuals as mentioned for February and the previous months may still be sown the early part of this month, also sweet peas. Sow amaranthus, aster, balsam, begonia, celosia, centaurea, cobaea, dahlla, gloxinla, hellanthus, hellotrope, humulus, hunnemannia, malope, mandevillea, marigold, mina lobata, nasturtium, pyrethrum, salplglossis, salvia, scablosa, verbena and zinnia. This is the best month in which to sow most kinds of tree seeds. Plant gladiolus, begonia, tuberose and dahlia bulbs.

Fruit Trees.-Planting of all deciduous fruit trees should be completed during this month. Citrus and other evergreen fruit trees may also be planted now.

Vegetable Garden.-Sow artichoke, asparagus, beans, Vegetable Garden,-Sow artichoke, asparagus, beans,
beets, late cabbage, carrot, celery, chervil, chicory, corn salad, sweet corn, cress, cucumber, dandelion, egg plant, endive, kale, kohl rabi, leek, lettuce, musk melon, watermelon, mustard, okra, onlon, parsley, parsnip, peas, pepper, potatoes, radish, rhubarb, salsify, Plant out cabbage, tomato and pepper plants.

\section{APRIL}

Flower Garden.-Sow amaranthus, aquilegia, aster balsam, celosla, cobaea, morning glory, centaurea, cos mos, cypress vine, dahlia, fuchsia, helianthus, heliotrope, humulus, hunnemannia, ipomoea mandevillea African and French marigolds, maurandia, mandevillea, ta, nasturtium, Iceland poppy, orlental poppy, portulaca, polyanthus, salplglossis, scablosa, Shasta daisy laca, polyanthus, salpiglossis, scablosa, Shasta daisy begonla, tuberose and dahlla bulbs; also chrysanthenum and aster plants.

Vegetable Garden.- Sow artichoke, asparagus, beans, beets, brussels sprouts, late cabbage, carrot, celery, chervil, late cauliflower, chicory, corn salad, swee corn, cress, cucumber, dandelion, egg plant, endive, kohl rabi, leek, lettuce, musk melon, waterm , endive, tard, okra, onlon, parsley, parsnip, weas, toes, pumpkin, radish, rhubarb, salsify, sorrer, potasquash, tobacco, tomato and turnip. Plant out cabbage, egg plant, pepper and tomato plants.

\section{MA Y}

Flower Garden.-Sow amaranthus, aquilegla, balsam, celosia, centaurea, cosmos, morning glory, cam panula, cypress vine, delphinlum, digitalis, helianthus humulus, hunnemannia, ipomoea, African and French marigolds, maurandia, mina lobata, nasturtium, por tulaca. Plant tuberose and dahlia bulbs, also aster and
chrysanthemum plants.
Vegetable Garden.-Sow artichoke, asparagus, beans, beets, brussels sprouts, carrot, late cabbage and caullflower, chervil, chicory, corn salad, sweet corn, cress, eucumber, dandelion, egg plant, ondive, lettuce, musk nelon. watermelon, mustard, okra, onion, parsley, parsnip, peas, peppers, potatoes, pumpkin, radish, salsify, cabbage, brussels sprouts, egg plant, pepper, tomato and sweet potato plants.

\section{J UNE}

Flower Garden.-Sow centaurea, cosmos, nasturtium and portulaca. Plant dahlia, chrysanthemum, aster. petunia, pentstemon and salvia plants.

Vegetable Garden.- Sow beans, beets, brussels sprouts, late cabbage and caullflower, corn salad, sweet corn, cress, cucumber, dandelion, egg plant, endive, lettuce, musk melon, watermelon, mustard, okra, onion parsley, peas, pepper, pumpkin, radish, spinach and squash. Plant out brussels sprouts, cabbage, cauliflower, egg plant, pepper, tomato and sweet potato plants.

JULY

Flower Garden.-Sow cosmos, nasturtium and portulaca seed.

Vegetable Garden.-Sow beans, beets, brussels sprouts, cress, cucumber, dandelion, endive, kale, kohl rabi, lettuce, mustard, okra, onion, parsley, peas, pumpkin, radish, spinach and summer squash. Plant
out brussels sprouts, cabbage and cauliflower plants.

\section{A UUST}

Flower Garden.-Sow calceolaria, cineraria, pansy. primula, stocks and Christmas flowering sweet peas. Vegetable Garden.-Sow beans, beets, brussels sprouts, early varieties of cabbage and cauliflower, cress, dandelion, endive, kale, kohl rabl, lettuce, mustard, onion, parsley, peas, potatoes, radish and spintions. Plant out brussels sprouts plants.

\section{SEPTEMBER}

Flower Garden.-Sow calceolaria, campanula, cineraria, pansy, pentstemon, primula, oriental poppy, Shasta daisy, stocks and Christmas flowering sweet peas. Plant bulbs of Lllium harrisil and $\mathrm{L}$. candidum.

Vegetable Garden.-Sow beets, early cabbage and cauliflower, carrot, corn salad, cress, dandellon, endive, parsnip, peas, potatoes, radish and spinach, also tomato for winter crop in frostless sections.

\section{OCTOBER}

Flower Garden.-This is a good month in which to sow hardy annuals in the open ground. Sow acroclinium, alyssum, bartonia, calendula, candytur, annual chrysanthemum, clarkia, collinsia, cosmos, eschscholtzia, godetia, larkspur, linum, lupinus, mignon-; ette, nemophila, poppies, sweet peas, pansy and stocks; also California Wild Flowers. Plant hyacinth

Vegetable Garden.-Sow beets, early cabbage, car rot, corn salad, cress, dandelion, endive, kale, koh rabi, leek, lettuce, mustard, onion, parsiey, parsnip. peas, potatoes, radish, spinach and turnip.

\section{NOVEMBER}

Flower Garden.-Sow hardy annuals in the open ground, such as acroclinlum, alyssum, bartonia, calendula, candytuft, annual chrysanthemum, clarkia, collinsia, cosmos, eschscholtzia, godetia, larkspur, linum. lupinus, mignonette, nemophlla, poppies, sweet peas, pansy and stocks; also Callfornia Wil tinue to plant hyacinths, tullps, narcissus and other utch bulbs.

Vegetable Garden.-Sow beets, early cabbage, carrot, corn salad, cress, dandelion, endive, kale, kohl rabl, potatoes, radish, spinach and turnip.

\section{DECEMBEF}

Flower Garden.-This is a good month in which to spade over the ground, spread a good thick dressing of stable manure over the surface and dig the ground as deeply as possible. Continue to sow hardy annuals in the open ground, acroclinium, alyssum, bartonia, in the open ground, acroclinium, alyssum, bartonia, calendula, candytuft, annual chrysanthemum, clarkia, collinsia, cosmos, eschscholtzia, godetia, larkspir, linum, lupinus, inignonette, nemophila, poppies, swee peas, pansy and stocks; also California

Vegetable Garden.-This is a good month in which to spade over the ground, spread a good thick dressing of stable manure over the surface, and dig the ground as deeply as possible. Sow beets, early cabbage, carrot, corn salad, cress, dandelion, endive, kale, koh peas, potatoes, radish, spinach and turnip. 


\section{FLOWERS AND PLANTS}

FOR DIFFERENT PURPOSES AND SITUATIONS, WHICH CAN BE GROWN FROM SEED

FLOWERING ANNUALS

Including some perennials which flower the first season from seed. Those marked ${ }^{*}$ are the best for massing in

Abronls

Acroclinium

- Ageratum

Anchusa

Antirrbinum

Arctotis

Argem

Baeria

Balsam

Begonis

Bellis

Brachycom

Browallia

- Calliopsia

- Candytuft

- Celosia

-Centaurea

- Chrysanthemum

- Cineraria

Collinsia

- Convolvulu.

- Coreopsis (native upec.

- Cornflower

- Cosmos

Dahlia

-Daianthus

"Dimorphothece

-Eschscholtzi

Floerkis beds and borders.

\begin{tabular}{|c|}
\hline $\begin{array}{l}\text {-Gafllardia } \\
\text { "Gilia } \\
\text { "Godetia } \\
\text { Gomphrens } \\
\text { Gypsophila } \\
\text { Helianthus } \\
\text { Helichrysum } \\
\text { "Hunnemannis } \\
\text { Jacobses } \\
\text { - Larkspur } \\
\text { Lavatera } \\
\text { Layla } \\
\text { Linaria } \\
\text { - Linanthus } \\
\text { "Linum } \\
\text { Lobelis } \\
\text { Love-lies-bleedin } \\
\text {-Lupinus } \\
\text { Jalope }\end{array}$ \\
\hline
\end{tabular}

- Marigold
Meconopsis
- Mentzelia
Mesembryanthemum
Mignonette
Mimoss
Mimulus
Mirsbllis
Myosotis
- Nasturtium
Nemesia
Nemophils
Nicotians
- Nigella
Oenothers
Pansy
Petunia
Phacelis
Phlox

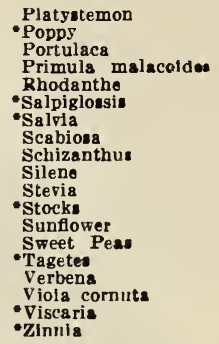

FLOWERING PERENNIALS

$\begin{array}{ll}\text { Agathaes } & \text { Coreopsis } \\ \text { Anchusa } & \text { Cyclamen } \\ \text { Aquilegis } & \text { Cynoglossum } \\ \text { Aurteuls } & \text { Daisy } \\ \text { Begonis } & \text { Dahlia } \\ \text { Bellis } & \text { Delphinium } \\ \text { Campanuis } & \text { Digitalis } \\ \text { Canna } & \text { Eryngium } \\ \text { Carnation } & \text { Erysimum } \\ \text { Chrysanthemum } & \text { Gaillardia } \\ \text { Clianthus } & \text { Gerbers }\end{array}$

Geranium
Myosotis
Nierembergis
Oenothers
Gypsophila
Heliotropium
Henchera
Hollyhock
Hunnemannis
Lupinus

Lobelis

Petunia

Phlox

Polyanthu:

Poppy, Iceland

Rompy,

Salpia

Scrbicas cancerte

Scabiosa columbaria

\section{FLOWERS FOR SHADED AND PARTIALLY SHADED PLACES}

Aquillegis

Begonia, Tuberous Collinsi

Clarkia
Collinsia
Cyclame:

Daisy
Digitalis
Floerkis

Lobelia cardinalis

Mimulu:

\section{Oenothers \\ Polysinthu}

Nemophila

Violes.
Annuals

Cardinal Climber
Convoivulus
Cucumber, Wild
Cypress Vine
Humulus
IDomoes

Humulus

Acroclinium

Antirrhinum

aquilegis

Arctoti:

Bider

Bartonia

Mins
Momordics
Nasturtium
Sweet Peas
Thunbergia
Tropaeolum

\section{CLIMBING VINES}

Perennials

\begin{tabular}{|c|c|c|}
\hline $\begin{array}{l}\text { Ampelopsis, se } \\
\text { Antigonion } \\
\text { Australian } \mathrm{Pe} \\
\text { Cobaea } \\
\text { Ipomoea }\end{array}$ & $\begin{array}{l}\text { see page } 36 \\
\text { vine }\end{array}$ & $\begin{array}{l}\text { Maucievilles } \\
\text { Maurandis } \\
\text { Smilax } \\
\text { Tacsonis } \\
\text { Wisteria, see nage } 42\end{array}$ \\
\hline
\end{tabular}

FL.OWERS FOR CUTTING PURPOSES

$\begin{array}{llll}\text { Calliopsis } & \text { Cosmos } & \text { Jacobaea } & \text { Salplglosis } \\ \text { Candytuft } & \text { Dahlia } & \text { Larkspur } & \text { Scabiosa } \\ \text { Carnation } & \text { Delphinium } & \text { Marigold } & \text { Sliasta Dais } \\ \text { Chinese Wool Flower } & \text { Gaillardia } & \text { Matricaria } & \text { Statice } \\ \text { Centaurea } & \text { Gerbers } & \text { Mentzelia } & \text { Stocks } \\ \text { Chrysanthemum } & \text { Gypsophila } & \text { Mignonette } & \text { Sunflower } \\ \text { Coreopsis } & \text { Pentstemon } & \text { Sweet Peas } \\ \text { Cornflower } & \text { Hunnthus } & \text { Poppies } & \text { Zinnis }\end{array}$

EDGING AND BORDER PLANTS

Agathaea

Ageratum

Alysum

Begonia, ever-bloomin

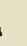

Candytuft, dwarf
Centaures candidissima

Daisy

Dimorphothecs

Marigold, French, Leg-

Myosotis
Nasturtium, Tom Thumb Nemophila

Pansies
Petunia, Rosy Morn
Phlox, Drummond
Polyanthus
Pyrethrum
Tagete

FRAGRANT FLOWERS

$\begin{array}{ll}\text { Abronia } & \text { Carnation } \\ \text { Alyenum } & \text { Centaurea } \\ \text { Candytuft } & \text { Cyclamen } \\ \text { Heliotroplum }\end{array}$

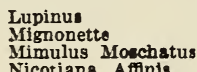

Mimulus Moschatu

Yolyanthus
Scabioss
Stocks Peas
Sweet Peas

Sweet William

iVallfower
ORNAMENTAL FOLIAGE PLANTS

$\begin{array}{ll}\text { Amaranthu } & \text { Kochia } \\ \text { Centaurea candidissima } & \text { Pyrethrum } \\ \text { Cineraria maritima } & \text { Ricinus } \\ \text { Coleus } & \end{array}$

PLANTS FOR HANGING BASKETS, ETC.

$\begin{array}{ll}\text { Alyssum } & \text { Maurandia } \\ \text { Asparagus Sprengerl. See } & \text { Nasturtium } \\ \text { page 43 } & \text { Nierembergia } \\ \text { Begonia } & \text { Petunis } \\ \text { Convolvulus mauritanicus } & \text { Smilas } \\ \text { Linaria cymballaris } & \text { Thunbergis } \\ \text { Lobelia } & \text { o }\end{array}$

\section{EVERLASTING FLOWERS}

Acrolinium $\quad \begin{aligned} & \text { Helichrysum } \\ & \text { Gomphrena }\end{aligned}$

$\begin{array}{ll}\text { Gomphrena } & \text { Rhodanthe } \\ \text { Gypsophila paniculats } & \text { Statice }\end{array}$

\section{HEDGE PLANTS}

$\begin{array}{ll}\text { Acacia armata } & \text { Ligustrum } \\ \text { Coprosma } & \text { Iyrtus } \\ \text { Crataegus } & \text { Prunus ilicifolla } \\ \text { Cupressus macrocarps } & \text { Pittosporum } \\ \text { Laurestinus } & \text { Privet } \\ & \text { Ules } \\ & \text { Viburnum }\end{array}$




\section{Flower Seed Novelties and Specialties}

\section{Antirrhinums or Snapdragons}

Snapdragons are among the most popular flowers rrown in CaHfornia. In the last few years great advancement has been made in the development of these lovely Lowers, both increasing the size of the blossoms and adding many new and delicate shades. The intermediate or semi-dwarf varieties grow from 15 to 24 inches high and are the most desirable for bedding. The tall varietles are the most desirable for bedang. 24 to 30 inches high and occount of their long stems are particularly valuable for cut flowers. Below stems are particularly valuable for cut flowers. Bevarietles of recent introduction.

\section{NEW GIANT SNAPDRAGONS}

Antirrhinum maximum

A new race of Giant Snapdragons producing flowers of enormous size on long spikes. Invaluable for cutting and also for display in the garden.

Apple Blossom. Delicate pink, white throat. Pkt. 25c. Canary Bird. Canary yellow. Pkt. 25c.

Copper King. Coppery scarlet. Pkt. 25c.

Gotelind. Light copper, old rose throat. Pkt. 25c.

Maralda. Coppe-y carmine. Pkt. 25c.

Nymph. Rosy lilac, white throat. Pkt. 25c.

Old Gold. Rich golden yellow. Pkt. 25c.

Purple King. Deep velvety purple. Pkt. 25c.

Wallflower. Brownish orange and copper red. Pkt. 25c.

SPECIAL OFFER. Full collection of the above ten rarieties, one packet of each, for $\$ 2.50$.

\section{TALL LARGE FLOWERED VARIETIES}

\section{Cardinai, Dazzling scarlet.}

Golden KIng. Large clear yellow.

LIIac Queen. White suffused with pale lilac.

Moonllght. Golden apricot and old rose.

Orange KIng. Orange scarlet, pink throat.

othello. Deep claret color.

Princess Patricia. Pale rose overlaid chamois.

Queen VIctorla. Very large pure white.

Rose Queen. Soft rose.

Venus. Pink on white ground, white throat.

The above varieties each, per pkt., 10c.

SPECIAL OFFER. Full collection of the above ten varieties, one packet of each, for 85 cents.

\section{INTERMEDIATE VARIETIES}

Amber Queen. Canary yellow, shaded chamois pink.

Bonfire. Orange buff, shaded scarlet.

Cottage Mald. Coral pink with white throat.

Empress. Rich velvety crimson.

Gmpress. Rich velvety crimson.

Mauve Beauty. Rosv mauve.

Old Rose. Soft blush pink, suffused terra cotta.

Purity. Pure white.

Silver PInk. Pearly pink, extra fine.

The Fawn. Terra cotta pink, suffused yellow.

The above varieties, each, per pkt., luc.

SPECIAL OFFER. Full collection of the above ten varieties. one packet of each, for 85 cents.

\section{Long Spurred Hybrid Aquilegias}

A magnificent strain of hybrid Columbines producing an abundance of very large flowers, with long spurs and borne on tall, graceful stems. The colors range in al shades of blue, lavender, mauve, yellow, orange, scarlet, rose-pink and white.

Mrs. Scott Elliott's Strain. An extra fine strain producing large flowers of the most delicate shades. Pkt. $25 \mathrm{c}$.

Rose Queen. Soft rose with white center. Pkt. 25c. Long Spurred Hybrids mixed. Pkt. $15 \mathrm{c}$.

\section{Improved Crego Giant, or Ostrich Plume Aster}

This magnificent strain is without doubt the best of the late flowering asters for our climate. They grow from 2 to $2 \frac{1}{2}$ feet high, and form strong, much-branched bushy plants. The flowers are produced in large quantities, on long wiry stems, and are of immense size, often four or five inches across; they are of the most perfect form, with long. hroad and curled petals. For cutting purposes this strain has no equal. I offer them in 6 different colors: White, Shell Pink, Deep Rose, Crimson, Lavender, Purple, or mixed. Each pkt. $15 \mathrm{c}, 1 / 8$ oz. $35 \mathrm{c}$.

SPECIAL OFFER. Full collection of the above 6 colors, one packet of each, for $75 \mathrm{c}$.

\section{Payne's California Giant Aster}

A new giant strain of Aster combining the tall branching habit of the American Beauty with the large flowers of the Ostrich Plume type. The plants grow 2 to 3 feet high and produce blossoms often 5 to 6 inches in diameter. The flowers stand shipping well and on account of their large size and long stems are highly recommended for cutting purposes. In four colors: Peach Blossom, Light Blue, Deep Rose, Deep Purple, or mixed. Each per pkt. $25 \mathrm{c}$.

\section{Payne's Single Comet Aster}

Single Asters on account of their simple grace and exquisite beauty are becoming more popular each season. For making a display in the garden it is hard to imagine anything more lovely than these single Asters, while as cut flowers for indoor decoration they have no equal. The plants of this strain are of branching habit and produce a wealth of large flowers with beautifully curled or twisted petals. White, PInk, Lavender or mixed. Each per pkt. $15 \mathrm{c}$

\section{American Beauty Aster}

This grand new Aster is one of the most valuable introductions of recent years and is quite distinct from any other variety. It is similar in growth to the Iate Branch. ing Aster but differs in that the blossoms are produced on longer and heavier stems. Some of these stems will measure over 2 feet in length. The flowers are produced in succession over a long period, they are very large, perfectly double and especially valuable for cutting purposes. In six colors: Peach Blossom, Pale Pink, Rose, Lavender, Purple, White, or mixed. Each per pkt. 25c, $1 / 8$ oz. $50 \mathrm{c}$.

Special Offer. Full collection of the above 6 colors, one packet of each, for $\$ 1.25$.

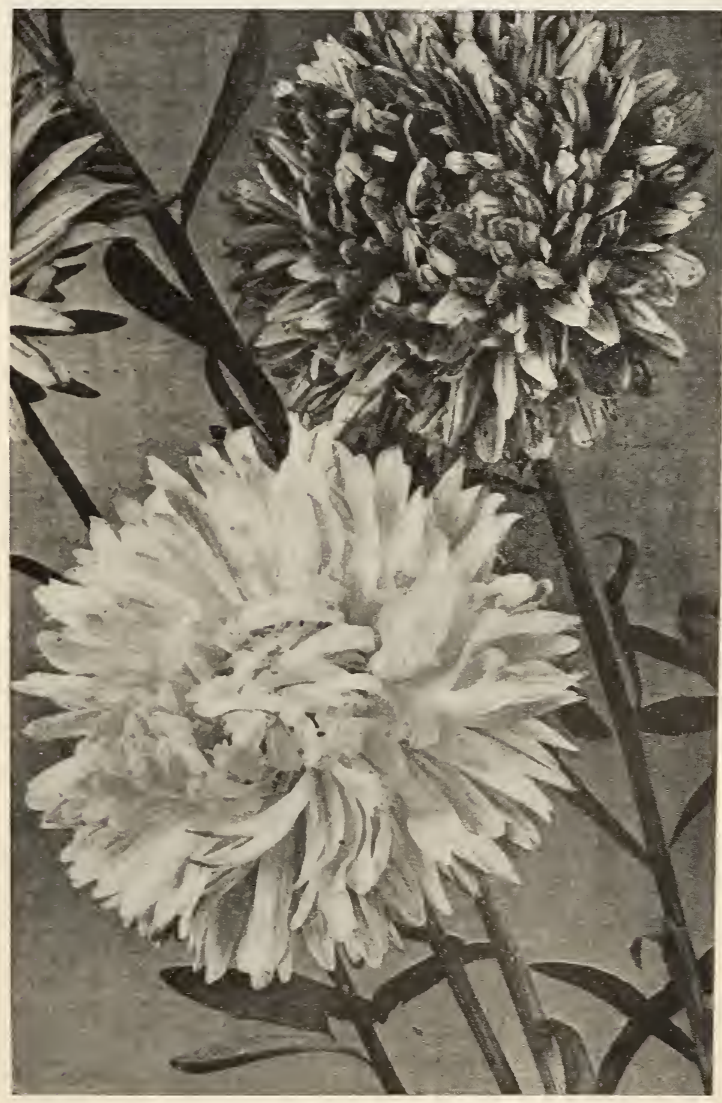

American Beauty Aster 


\section{Anchusa italica, Dropmore}

This beautiful perennial plant is of recent introduction and should be planted in every garden. The plants grow 4 to 5 feet high and are remarkable for their free and continuous blooming. The flowers, which are produced In long spikes, are of a rich gentian-blue shade. Pkt., $15 \mathrm{c}$.

\section{Bidens dahlioides}

A hardy perennial producing large quantities of single. Cosmos-like flowers of a beautiful light pink shade. The flowers keep well in water and are excellent for cutting of March the plants will flower the first season. Pkt., 25c

\section{Calendula, The Ball}

An extra fine strain of Calendula of upright growth bearing very large, uniformly double flowers. The color is deep orange passing to a lighter shade toward the center. The flowers are produced on very long, stiff stems and are especially desirable for cutting. Pkt. 25c.

\section{Carnation, Chabaud's Giant}

This new strain is a great acquisition in Carnations. The plants come into bloom 6 months from seed and continue to flower all summer. They throw up from 10 to 20 stalks bearing large flowers of good form and come $90 \%$ double and true to color.

Jeanne Dionis. Pure white. Pkt. 25c.

Legion of Honor. Copper red. Pkt. $25 \mathrm{c}$

Marie Chabaud. Yellow. Pkt. 25c.

Nero. Very deep crimson. Pkt. 25c.

Sparkler. Cardinal red. F'kt. 25c.

The Pearl. Rose pink. Pkt. 25c.

\section{Cardinal Climber}

A new and absolutely distinct annual climber, being the result of a cross between Ipomœa quamoclit, "Cypress Vine," and Ipomœa coccinea. I consider this the most brilliant and beautiful annual vine ever introduced. It will no doubt attract universal attention, not only for we ers, but for its hardiness, its quick growth, reaching a height of 20 to 25 feet in a short time, and also for its height of 20 to 25 feet in a short time, and also for its rich green, laciniated foliage, which resembles that of a fine Japanese Maple. The flowers, which are about $1 \frac{1}{2}$
inches in diameter, the tube being about $11 / 4$ inches in length, are borne in clusters of from 5 to 7 , and their vivid cardinal-red color against the abundant dark green foliage is most effective. This vine thrives best in a good soil and a warm, sunny situation. Sow the seed in the open ground as soon as the weather is warm and settled. Pkt.. 15c.

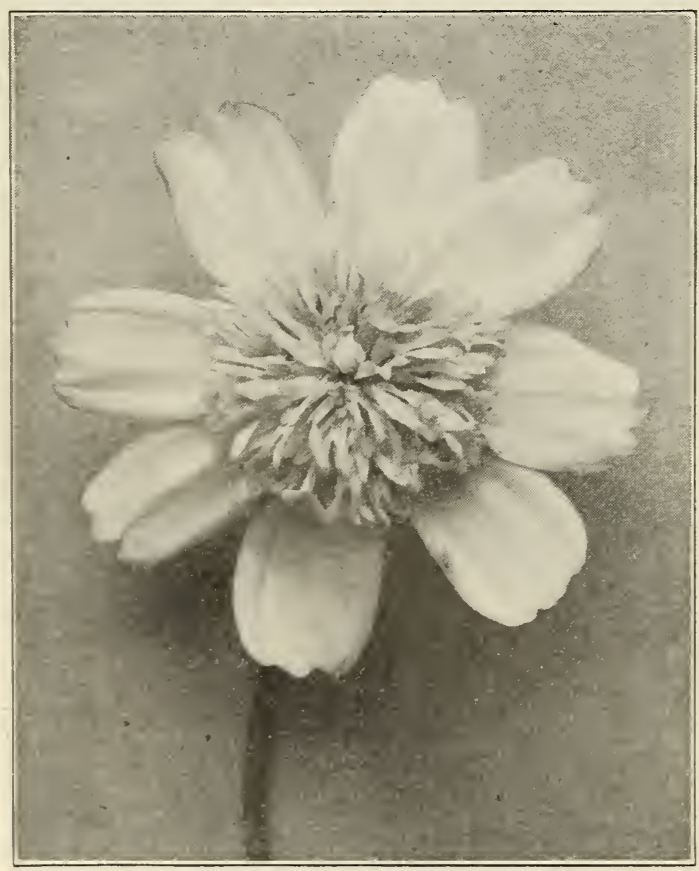

Anemone Flowered Cosmos

\section{Payne's Large Flowered Cineraria}

Cinerarias have become very popular of recent years not only as greenhouse plants but also for out-door culture in sheltered and shady situations, and we regard them as one of the most valuable plants for making a display in the garden during the late winter and spring months. For early flowering, sow the seed in May or June and later sowings up until September. Sow the seed in seed pans of finely screened soil, composed of leaf mold and sand. pot off the leaf mold and sand. As soon as large enough pot off the young seedlings and later transfer to larger
pots until ready to plant out into the open ground.

Azure Blue. Pkt. 50c

Matador. Scarlet. Pkt. 50c.

Old Rose. Pkt. 50c.

Royal Blue. Pkt. $50 \mathrm{c}$

Extra Choice Mixed. Pkt. 50c.

\section{Cineraria}

STELLATA AND CRUENTA HYBRIDS

This strain is especially desirable for making a display In the garden and is very hardy, succeeding with little care. It forms strong, pyramidal plants, 2 to 3 feet high covered with hundreds of star-shaped flowers. The seed I am offering has been carefully selected and will be found to contain a large percentage of blue shades. found to

\section{Anemone Flowered Cosmos}

Though not exactly a double flower, on the disk flowers chere is produced a thick beard-like growth, giving the flower a full or double appearance in the center, as seen In the accompanying illustration. While they do not come altogether true from seed, a large percentage of the plants produce flowers with this peculiar phenomenon more or less in evidence, the remainder bearing large more or less in evidence, the remainder bearing large hlossoms of the ordinary type. I offer them in four dis15c; Crimson King, pkt., 15c; Malmaison Pink, pkt., $15 \mathrm{c}$; mixed, pkt., $15 \mathrm{c}$.

\section{Cynoglossum amabile \\ "Chinese Forget-me-not"}

A beautiful perennial from Southwest China which sucA beautiful perennial from southwest China which suchigh, producing great quantities of flowers of a true Forget-me-not blue. It makes a splendid display in the garden and is also desirable for cutting purposes. Pkt. $25 \mathrm{c}$.

\section{Chinese Wool Flower}

This celosia from China is a novelty of great merit and attracted a great deal of attention during the past season The plant grows from 2 to 3 feet high and has an im mense globe-shaped flower head of crimson-scarlet color resembling a large ball of wool, often 7 or 8 inches in diameter. Besides the main central stem the plant throws out numerous side branches each terminating in a ball of crimson wool. It blooms profusely during summer late in the late in the season. Very effective for planting in bed
and borders, also valuable for cutting purposes. Pkt., $25 \mathrm{c}$

\section{Giant English Cyclamen}

A great improvement on the ordinary Giant Cyclamen The plants are of robust growth with rich heavy foliage. The flowers are very large and produced in great profusion and come in many rich colors. The seed I am offering is imported from a specialist in England.

DUKE OF FIFE. Deep lilac rose. Pkt. $50 \mathrm{c}$. GIANT CRIMSON. Brilliant crimson. Pkt. 50c. SALMON KING. Bright salmon pink. Pkt. 50c. GIANT WHITE. Pure white. Pkt. 50c. GIANT MIXED. Pkt., 25c.

\section{Delphinium Belladonna}

This magnificent strain of Delphinium is now in great demand. The plants grow from 2 to 3 feet high, and from demmerous stems from the crown, but require no staking. numerous stems frorn the crown, but require no staked the spike so that they stand out boldly from the main on the spike so that they stand out boldy from the main stem presenting a most graceful appearance, especially desirable for cutting. Perhaps the most valuable feature of these plants is their extreme free flowering qualities. It well cared for, and the old stems are kept cut off, they will flower almost the year round

Belladonna. Light blue. Pkt., 25c; 1/8 oz., 60c.

Bellamosa. Dark blue. Pkt.. 25c; 1/8 oz., $60 \mathrm{c}$.

Belladonna hybrids. Various shades of light and dark blue. Pkt., 25c; $1 / 8$ oz. $75 \mathrm{c}$. 


\section{Delphinium Chinense, Tom Thumb}

A very dwarf variety of Chinese Delphinium bearing a great profusion of large ultramarine blue flowers. The dwarf habit, free flowering qualities and intense blue bedding purpose. Pl.t. $25 \mathrm{c}, 1 \mathrm{~s}$ oz. $50 \mathrm{c}$.

\section{"Queen Ann's Blue Lace" \\ Didiscus Coeruleus}

Though not new this valuable annual has only recently been introduced into California. The plants are of upright growth and produce numerous heads of sky blue flowers. It succeeds well in the open ground and also makes an excellent pot plant. Pkt. $25 \mathrm{C}$

\section{Digitalis, The Shirley}

A very fine strain of Foxglove raised by the late Rev. W. Wilks of Shirley Vicarage, England, originator of the famous Shirley Poppy. The plants grow 5 to 6 feet high and produce enormous spikes of large flowers. The color: range from white and shell pink to deepest rose, beautifully spotted and blotched with crimson or chocolate brown. Pkt., 25c.

\section{Freesia hybrida Ragionieri}

This is without doubt one of the most remarkablo novelties of late years. The fragrant blossoms are pro. duced in the most exquisite shades of rose, pink, blue purple, violet, yellow, orange and brown, often delicately purple, violet, yellow, orange and brown, often delicatel. veined and spotted. The culture is the same as for the or eight months from the seed. Pkt., $15 \mathrm{c}$.

\section{"Scarlet Transvaal Daisy" Gerbera Jamesonii}

This beautiful plant from South Africa thrives quite well in our California climate, and is becoming very popular here. The plants require a good rich soil, with plenty of drainage and a sunny location. The flowers resemble a marguerite in shape, but are of an intens scarlet-crimson color. They are produced on long stems and last a long time when cut. The seed should be sowr in seed pans of light, well-drained soil, and kept in 8 in seed pans of light, well-drained soil, and kept in glass house or frame, and the young plants can after-
wards be transplanted to the open ground. Pkt., $25 \mathrm{c}$.

\section{Gerbera Jamesonii hybrida}

The flowers of these magnificent hybrids of the Trans vaal Daisy are of about the same size as those of the parent, but range in all shades from pure white, yellow. orange, salmon, rose, cerise, ruby-red to violet. Pkt., 25c

\section{New Yellow Geum-Lady Stratheden}

Without doubt this is one of the finest introduction of late years. The flowers are just as large and double as those of the popular variety Mrs. Bradshaw, but are of a deep, rich golden yellow. It makes a fine display in the garden and is excellent for cutting. Plants from see mer. in the fall

\section{"Payne's Tree Lupine" Lupinus Paynei}

A native California species discovered by the writer in the foothills near Santa Susana and named in his hono by Dr. Anstruther Davidson, the "well known botanis of Los Angeles.

I believe this is the most wonderful Tree Lupine in the world. It forms large round topped shrubs 4 to 8 fee high from a trunk-like base 3 to 4 and sometimes inches in diameter. One large specimen measured inches through the trunk, $8 \frac{1}{2}$ feet high and $131 / 2$ feet through the crown and when in blossom had over 500 flower spikes in bloom at one time.

The foliage is very handsome and silvery green, and the flowers are produced in racemes 8 to 15 inches long. They remind one of wistaria blossoms and appear in many beautiful shades: hardly two plants are just alike: some are pale blue others lavendor plants are just alike: purple, rose pink, flesh pink or white; all with a beaupurple, rose pink, flesh pink or white; all with a beautiful yellow blotch on the standard. The blossoms are deliciously fragrant, a few flowers being sufficient to perfume a whole house. The plants bloom in the spring and the whole bush blossoms simultaneously. They grow in over night and plant about one inch deep in the open eround where the plants are to remain. Pkt. $25 \mathrm{c}$

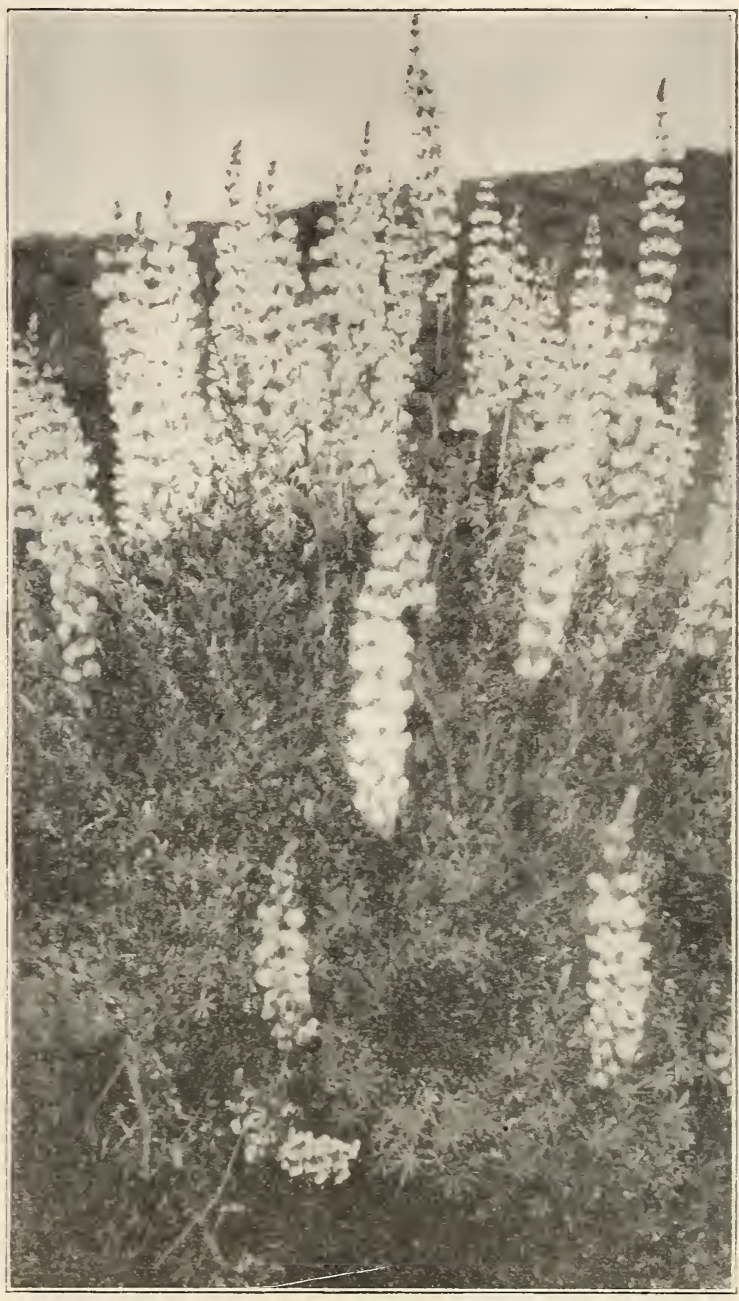

Luplnus Paynel

\section{Texas Blue Bonnets}

\section{(LUPINUS TEXENSIS)}

Everyone who has ever lived or traveled in Texas is no doubt familiar with the Texas Blue Bonnets which ir many places cover the plains with masses of rich blue flowers. This season I have been fortunate enough to secure direct from Texas a limited quantity of seed of this beautiful plant. Pkt., 10c; oz.. 50c; $1 \mathrm{~b} . \$ 6.00$

\section{Nemesia strumosa suttonii Hybrids} A veautiful annual of recent introduction which suc,
ceeds quite well in California and is especially valuable
for winter blooming. The plants grow about i foot high for winter blooming. The plants grow about 1 foot high and produce large quantities of orchid-like blossoms in scarlet, beautifully marked and shaded. In three colors, orange, rose, scarlet or mixed. Each per plit.. 25c.

\section{Nemesia Dwarf, Blue Gem}

One of the most valuable introductions of recent years. 1 very dwarf, compact variety, with bright blue flowers produced in great profusion. Very desirable for beds, for edgings or as a ground cover for bulb beds, a good winter bloomer. Pkt. $25 \mathrm{c}$.

\section{Payne's Royal Exhibition Pansy}

This is undoubtedly the most superb strain of Pansies ever offered on this coast. The plants are of vigorous crowth, and are particularly free flowering. The blossoms are very large, and of fine, velvety texture inblotched, spotted and margined. Pkt., 25c; 1/8 oz., $\$ 1.25$. 


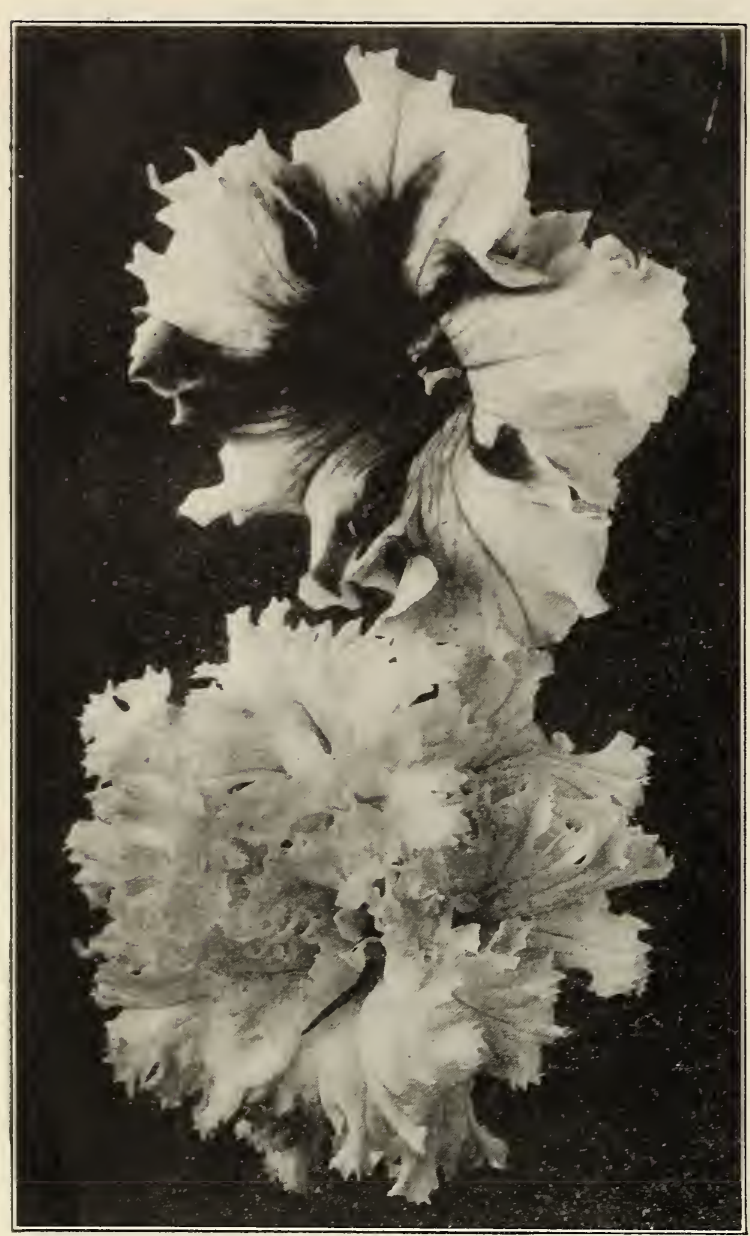

Payne's Giant Petunias

\section{Petunia, Payne's Giant Double Paeony Flowered}

This is without doubt the finest strain of double Petunias ever offered and produces as high as $70 \%$ double flowers. The blossoms are of immense size, often double flowers. The 4 or 5 inches in diameter, cory and of every conceivable color. Pkt. 50c.

\section{Petunia, Payne's Giants of California Ruffled and Fringed}

The Petunia is one of the most popular plants in Calicornia gardens. This superb giant strain I am offering cornia gardens. This superb glant strain I am oflering produces Immense flowers of great substance, often 4 or of the petals beautifully ruffled and fringed. They include all the richest colors and combinations of colors, many of them beautifully veined, mottled or striped. many of

\section{New Petunia, Triumph}

For a long time there has existed a demand for a Petunia of the giant ruffled type in a good shade of pink and I believe this new variety will fill that want. The flowers are large, beautifully ruffled and of a clear bright pink. The plants are of strong growth and very free blooming. This new variety will be especially valuable color scheme. Pkt. $25 \mathrm{c}$.

\section{Giant Petunia, Steel Blue}

A very desirable variety of the giant ruffled type flowers very large, steel blue veined with black, quite a unique shade. Pkt., $25 \mathrm{c}$

\section{Giant Petunia, Romany Lass}

This is one of the finest introductions in petunias of recent years. The flowers are very large and beautifully ruffled; color a rich bright crimson (Hoosier Beauty shade) with purple throat. The plants are very free flowering and produce a great display of color when planted in masses. Pkt., 25c.

\section{Western Poppy}

A very rare native poppy of exquisite beauty. The plants are of slender fragile growth reaching a height of 1 to 2 feet and succeed best in partial shade. Flowers orange-scarlet with pale yellow center. It is an annual and the seed should be sown in the open ground in fall or very early spring. Pkt. $25 \mathrm{c}$.

\section{New Poppy, Ryburgh Hybrids}

This splendid new strain of annual poppy produces plants of bushy habit, carrying quantities of longstemmed flowers in charming shades of flesh salmon. orange, pink, rose and carmine. The flowers are double and semi-double and last well when cut. Pkt., 25c.

\section{New Poppy, Eldorado}

A lovely strain of annual poppies of the Shirley typo, producing in great abundance, large double flowers measuring about 3 inches across. They come in the most delicate and brilliant colors. ranging from palest pink through shades of rose and salmon to rosy scarlet. Some are white with salmon-pink or crimson margins, others are white with salmon-pink or crimson margins, others scarlet shaded white, cherry red and white or scarlet with white center. They attain a height of about 2 feet and are of great decorative value for cutting. Pkt., 25c.

\section{The Flanders Poppy}

The Wild Red Poppy so familiar to those who served in the recent European conflict, and to those who hold other memories of that continent. All through Western Europe this poppy grows wild in the fields and along the roadsides. Scattered through ricening wheat its faming red blossoms show in striking and beautiful contrast to the clear, golden yellow of the maturing grain, making a picture of country-side loveliness ing grain, making a picture of country-side loveliness that is never to be forgotten. It is from this wild poppy that the Rev. W. Wilks of Shirley Vicarage, England, produced the well-known Shirley poppy and from which many other
nated. Pkt. $15 \mathrm{c}$, oz. $75 \mathrm{c}$.

\section{Primula malacoides}

This valuable introduction from China has proved to This ve the most free-flowering species and especially ue one of the most free-flowering species and especially is quite hardy and is one of the best winter flowering plants we have. It is also well suited for pot culture. The flowers are of a delicate shade of lilac. Seed sown in August produces plants which flower throughout the winter months. Pkt., 25c.

\section{Schizanthus Wisetonensis}

One of the daintiest of annual flowering plants and adapted for sowing in beds or borders. The seeds germinate quickly and the plants flower in a remarkably minate quick When in bloom the foliage is almost com. short time. When in bloom the foliage is almost completely hidden by the immense number of delicate butterrose. Makes an admirable pot plant for house or conservatory. Pkt., $15 \mathrm{c}$.

\section{Schizanthus, Gärraways Hybrids}

A new select strain, especially desirable for forcing, splendid range of colors. Pkt., $25 \mathrm{c}$.

\section{Scabiosa caucasica}

A beautiful perennial Scabiosa. The plants grow 2 to 21 feet high and produce large lavender flowers 3 to 4 inches across on long wiry stems. They last well in water and are very desirable for cutting. The plants are very free flowering, blooming continuously from the end of June until late in the fall. Pkt., 25c.

\section{Scabiosa columbaria}

A perennial Scabiosa from South Africa and one of the best introductions of recent years. The plants grow 11/ to 2 feet forming bushes often 2 feet across. The flowers are pale lavender 2 to $2 \frac{1}{2}$ inches in diameter and produced in great profusion from early spring to fall. Pkt. $25 \mathrm{c}$. 


\section{Scabiosa grandiflora, Peach Blossom}

Quite a new shade in the annual Scabiosa. The flowers are very large, perfectly double and on long stems; color a beautiful shade of peach blossom pink, very desirable as a cut flower. Pkt., 25c.

\section{NICE GIANT STOCKS}

The Nice stock has proved to be pre-eminently the stock for Southern California and has become very popular of late, so much so, that I have discontinued listing lar of late, so much so, that I have discontinued listing many of the of large double plants about 2 feet high, producing spikes or large double flowers not tightly clustered but borne along the entire stem. They are very graceful and especially desirable for cutting. The plants are extremely free flowering, continuing in blossom for a long time. For winter flowering sow the seed in July and August. In transplanting stocks care should be taken to save the small or weak growing plants, as these generally produce double flowers, while the strong, robust growing seedlings ofter eome single. The seed I am offering here is from one of the best specialists, and contains several new varieties of great merit.

Beauty of Nice. Flesh pink. Pkt., 15c; 1/8 oz., $65 \mathrm{c}$. Belle d'Napies. Old rose. Pkt., 15c; 1/8 0z., $75 \mathrm{c}$

Cote d'Azur. Deep lilac. Pkt., 15c; $1 / 8$ oz., $75 \mathrm{c}$.

Hear, deep rose shading to pale pink and chamois toward center, large spike, extra fine. pink and chamois toward

Madame Joseph Paquet. New, deep cream-color overlaid chamois. Pkt., 25c; 1/8 oz., $\$ 1.00$.

Queen Alexandra. Lilac rose. Pkt., 15c; 1/8 oz., 65c.

Queen of the Belgians. Silvery lavender, very large spike, extra fine. Pkt., 25c; 1/8 0z., $\$ 1.00$.

Snowdrift. New, improved pure white, extra fine. Pkt., $25 \mathrm{c}$; $1 / 8$ oz., $\$ 1.00$.

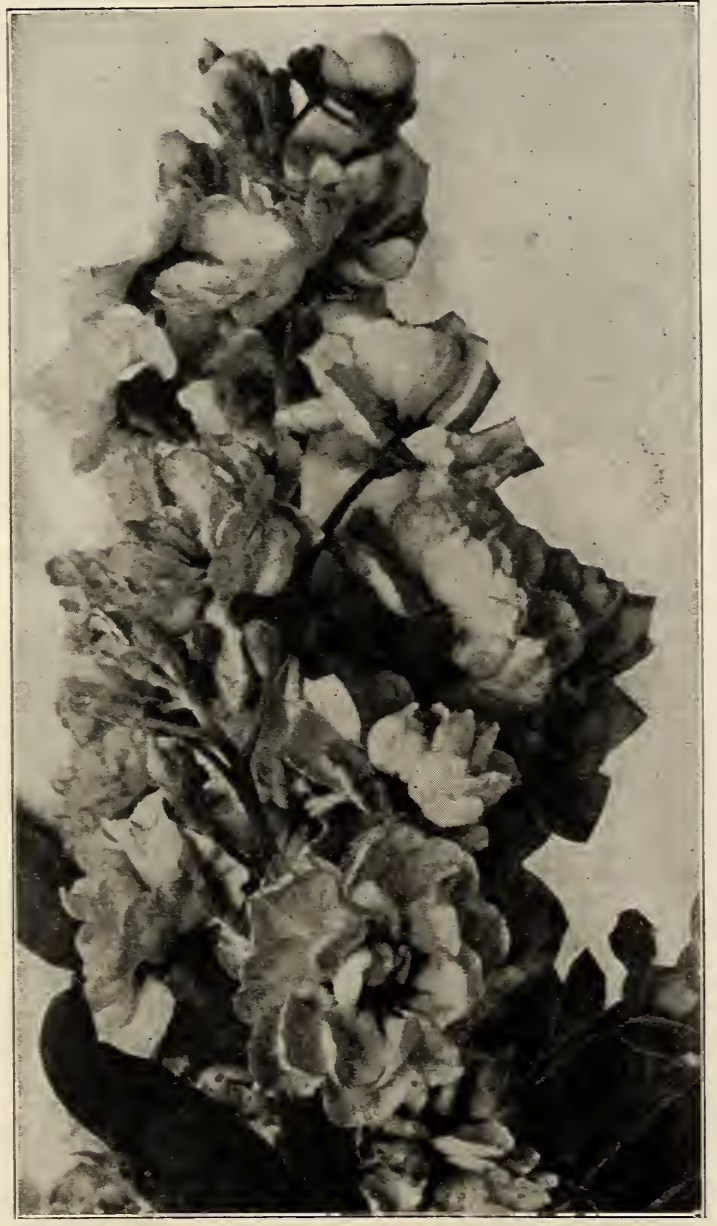

Nice Giant steck
Souvenir de Monaco. Crimson. Pkt., 15c; 1/ oz., 75c. Souvenir de Monte Cario. Cream color. Pkt., 15c; 1/8 oz., $75 \mathrm{c}$.

Summer Night. Deep purple. Pkt., 15c; 1/8 oz., $75 \mathrm{c}$.

Nice Giant. All colors mixed. Pkt., 15c; 1/8 oz., 50c.

Nice Giant, Payne's Special Mixture of Pastei Shades. Pkt., 25c; 1/8 oz., $\$ 1.00$.

\section{Bismarck or Giant Imperial Stocks}

This class of Giant-Ten-Week Stocks is of great merit and only needs a trial to be thoroughly apprecialed by every flower grower. The plants grow from 2 to $2 \frac{1}{2}$ feet high and are of branching habit, producing numerous large spikes measuring 12 to 16 inches long. They are especially desirable for cutting and produce a high percentage of double flowers. I offer them in 9 distinct colors. White, Cream-color, Chamols, Fiesh Pink, Rose, Blood Red, Lilac, Lavender, Deep Purple, or mixed. Each, per pkt., $25 \mathrm{c}$.

\section{"Mexican Sunflower"}

Tithonia Speciosa

A rare plant from Mexico. Annual throwing up from the root many stout, woody stems furnished with rather large foliage. The flowers are large and remind one of an immense single zinnia; color dazzling orange scarlet It forms a large shrubby plant, flowers for a long period and is especially desirable for planting among shrubs or in the background of wide borders. Pkt., $15 \mathrm{c}$.

\section{Verbena hybrida gigantea}

This splendid new strain of verbena is one of the finest introductions of recent years. The plants are of robust, compact habit and particularly free flowering. The flower trusses are of immense size and the individual florets an inch or more in diameter. In 4 colors. Blue with white eye, scarlet with white eye, flame pink, pure white or mixed. Each per pkt., $25 \mathrm{c}$.

\section{Viola cornuta, Papilio}

Though not as large as the regular pansy, this variety is so free flowering that it is far superior for bedding purposes. The plants begin to bloom when quite young and produce a never ending succession of delph blue flowers. It is ideally adapted for lining along walks or for bordering beds of other annuals. For making a display in the winter and spring months there is no variety play in the winter and spring month

\section{Winter Flowering Wallflower}

A very desirable plant, producing great quantities of flowers all through the winter and spring. The flowers are fragrant and come in a great variety of colors, ranging from cream color to primrose, sulphur yellow, golden yellow, lilac, mauve, purple and violet. Cannot be equaled for display of color in the winter garden. It succeeds best in a shady or partially shady place, but will also thrive in the full sunlight. Plants from seed sown early in fall will bloom the following winter. Pkt., 25c.

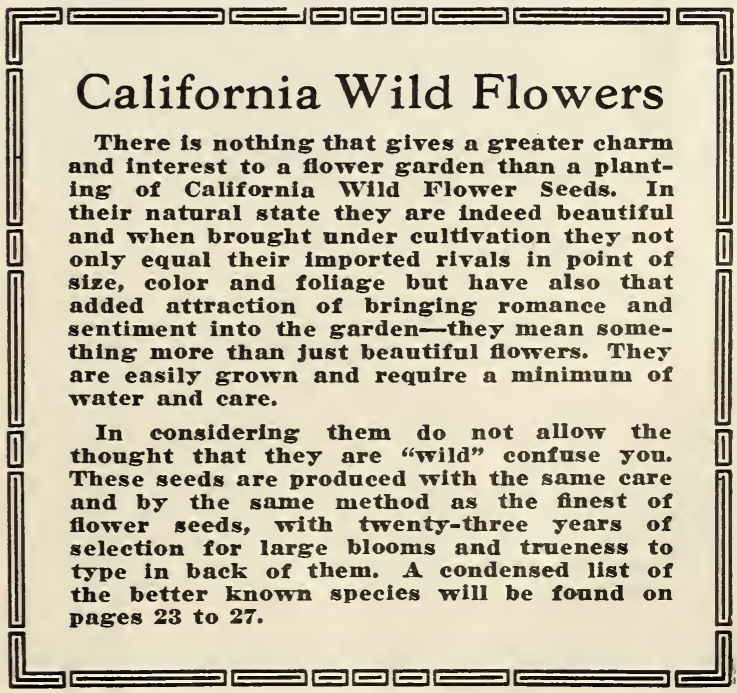




\section{Payne's Giant Double Zinnia}

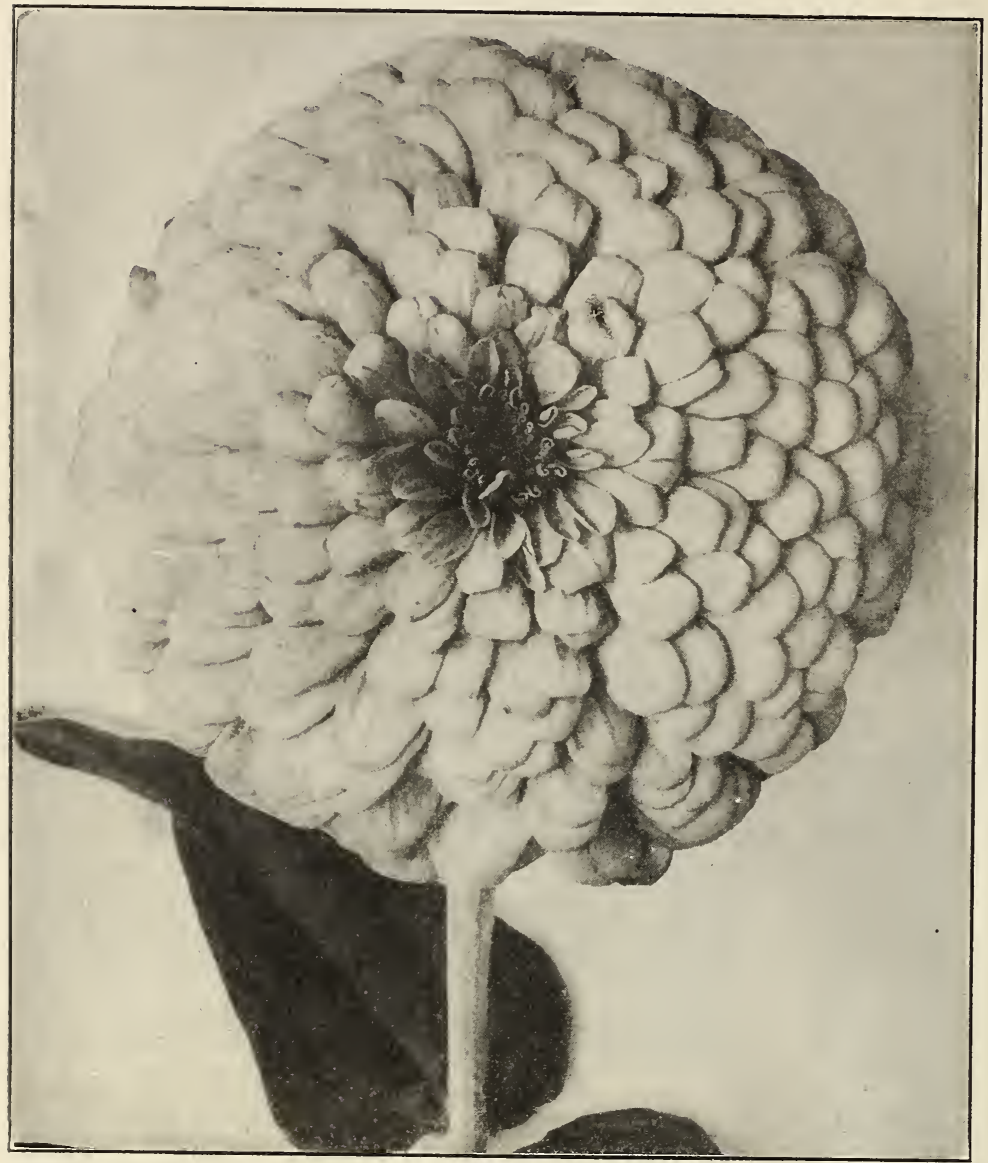

Payne's Giant Double Zinnia

\section{New Dahlia Flowered Zinnia}

A new and distinct race of Zinnia which is very popular. Plants are of which is very popular. Plants are of sturdy growth forming bushy plants 2 immense double flowers on long stems. Blossoms are the largest of any Zinnia ever grown and when fully developed often measure 4 inches in depth and 6 inches in diameter. Petals are larger and broader than the ordinary giant zinnia and give the flower a resemblance to a show dahlia. In the color of the flowers there is a wonderful range, including golden yellow, burnt range, including golden yellow, burnt orange, old rose, cerise, mauve, terra charming shades.

Exquisite. Light rose, center deep rose, of true dahlia flowered type. The most pleasing of collection. Pkt. 25c, $1 / 8$ oz. $75 \mathrm{c}$.

Old Rose. Beautiful old rose shade. ery large. Pkt. 25c; $1 / 8$ oz $75 \mathrm{c}$.

Crimson Monarch. Rich crimson, immense flowers. Pkt. $25 \mathrm{c}, 1 / 8$ oz. $75 \mathrm{c}$. Giant Attraction. Brick red, form ing immense ball of color. Pkt. 25c, $1 / 8$ oz. $75 \mathrm{c}$.

Golden State. Rich orange yellow. Plkt. 25c, 1/8 oz. $75 \mathrm{c}$.

Scarlet Flame. Bright scarlet, blended orange. Pkt. 25c, 1/8 oz. $75 \mathrm{c}$.

Meteor. The darkest shade of red. very large. Pkt. $25 \mathrm{c}, 1 / 8$ oz. $75 \mathrm{c}$.

Oriole. Orange and gold, immense flower, very beautiful. Pkt. 25c, 1/8 oz. $75 \mathrm{c}$.

Dream. Deep lilac, turning to mallow purple. Pkt. $25 \mathrm{c}, 1 / 8$ oz. $75 \mathrm{c}$.

Canary Eird. Beautiful light yellow. Pkt. 25c, $1 / 8$ oz. $75 \mathrm{c}$.

Dahlia-Flowered Mixed. Pkt. 25c, $1 / 8$ Oz. $50 \mathrm{c}$.

SPECIAL OFFER. Collection of any six of the above, one pkt. each. for $\$ 1.25$. Collection of the whole 10 colors, one pkt. each, for $\$ 2.00$.

\section{Payne's Giant Double Zinnia}

Zinnias are among the most popular of the summel flowering annuals, producing a grand display of brilliant and dazzling colors for many months, with little care and attention. The plants of this giant strain are of extremely robust growth, attaining a height of from 2 to $21 / 2$ feet; bearing immense flowers, often 5 inches in diameter, very double, and of the most striking colors I offer this superb strain in 14 distinct shades.

Apricot Yellow. Pkt., 15c; 1/8 oz., 35c.

Buff. Pkt., $15^{\circ} \mathrm{c}$; $1 / 8$ oz., $40 \mathrm{c}$.

Bright Rose. Pkt., 15c: 1/8 oz., 35c.

Burnt Orange. Pkt., $15 \mathrm{c} ; 1 / 8$ oz., $40 \mathrm{c}$.

Canary Yellow. Pkt., 15c; 1/8 oz., 35c.

Crimson. Pkt., $15 \mathrm{c}$; $1 / 8$ oz., $35 \mathrm{c}$

Flesh Pink. Pkt., $15 \mathrm{c} ; 1 / 8$ oz., $40 \mathrm{c}$.

Orange King. Pkt., 15c; 1/8 oz., $50 \mathrm{c}$

Purple. Pkt., 15c; 1/8 Oz., 35c.

Rose King. Pkt., 15c; $1 / 8$ oz., $40 \mathrm{c}$.

Rose Queen. Pkt., 15c; 1/8 oz., 50c.

Salmon Pink. Pkt., $15 \mathrm{c}$; $1 / 8$ oz., $40 \mathrm{c}$.

Scarlet. Pkt., 15c; 1/8 oz., 35c.

Shrimp Pink. Pkt., 15c: 1/8 oz., 40c.

All Colors Mixed Pkt., 15c; $1 / 8$ Oz., $25 \mathrm{c}$.

SPECIAL OFFER. Collection of any six of the above, one pkt. each, for 75c. Collection of the whole 14 colors,

\section{Payne's Giant Double Zinnia Special Mixture of Pastel Shades}

The Zinnia is one of the most desirable of our summer and fall flowers for cutting purposes. They last a long time in water and are very decorative. However, many of the colors are too dazzlingly bright, and though we may admire them in the garden, they are not suited to produce artistic effects in the house. On the other hand, many of the lighter shades are very delicate and desirable for decorative purposes. Of late years there has been a great demand for Zinnias in the pastel shades, and this season I am offering a very carefully made up mixture which will be found to include all the most delicate art tints. Pkt., 15c: $1 / 8$ oz., $40 \mathrm{c}$.

\section{Zinnia elegans pumila}

The best type of zinnia for bedding purposes, making a great display of color when planted in masses. The plants grow $1 \frac{1 / 2}{2}$ to 2 feet high, of bushy habit, and plants grow 1/2 to summer. The flowers are of meflower throughout the summer. The flowe stems: desirable for cutting as well as for display in the garden.

Bright Scarlet. Pkt., 10c; $1 / 4$ oz., $40 \mathrm{c}$

Canary Yellow. Plkt., 10c; $1 / 4$ oz., $35 \mathrm{c}$

Canary Yellow. 10., $1 / 4$ oz., $35 \mathrm{c}$.

Golden Yellow. Pkt., 10c; '1/4 oz, 40c.

Golden Yellow. Pkt., 10c; $1 / 4$ oz., $40 \mathrm{c}$

All Colors Mixed. Pkt., $1 \mathrm{Cc}$; $1 / 4$ oz., $30 \mathrm{c}$.

SPECIAL OFFER. Collection of the above five colors, pret each for $40 \mathrm{c}$ 


\section{General List of Choice Flower Seeds}

In sowing flower seeds in California it must be remembered that the conditions are entirely afferent from those existing in the Eastern States. There the time for sowing all hardy and half hardy annuals is in the spring, while in California the majority of them a best when sowmence to grow early part of the Winter; this being the sea to plant most annuals in our gardens. There are, however, some exceptions to this rule, such as Asters, Zinnia, Portulaca, etc., which are distinctly Summer flowering plants. In the following pages I have endeavored to give the Fall and Winter months are the best time.

ACROCLINIUM. "Everlasting Flower." Annual 1 to 13/2 feet high. Pretty daisy-like flowers, very effec$13 / 2$ feet high. tive for bouquets eith long stems, just as the flower For drying, cut with lie in bunches and hang up, commences to open, tie in bunches and hang up, with the flower downwards, for 4 or 5 weeks until thoroughly dry. It succeeds best in California when grown in the winter season.

Rose, white, or mixed. Each per pkt., 10c; oz., $75 \mathrm{c}$.

A GATHAfa CoELESTIS. "Blue Daisy." Perennial, 1 to $11 / 2$ feet high. A pretty little plant blooming almost the year round. Flowers skyblue with yellow centers. Useful for beds, borders, rock gardens and window boxes. Sow the seed in fall or early spring in seed boxes and wh.

GERATUM MEXICANUM. Annual, 9 to 12 inches GERATUM MEXICANUM. Annual, 9 to in clusters, high. A favorite bedding plant; flowers of brush-like appearance; very free flowering and in bloom nearly all through the season. Seed sh. Imperial Dwarf Blue. Light blue. Pkt. $10 \mathrm{c}$. Blue Perfection. Deep blue. Pkt. $15 \mathrm{c}$.

ALYSSUM. Free flowering annual, useful for beds, edgings, etc.

maritimum. "Sweet Alyssum." White; height 6 to 9 inches. Pkt. $10 \mathrm{c}$. oz. $40 \mathrm{c}$.

Little Gem. Dwarf, 4 to 6 inches. Pkt., $10 \mathrm{c}$; oz., $60 \mathrm{c}$. Carpet of Snow. Very dwarf. Pkt., 10c; oz., $75 \mathrm{c}$. Lilac Queen. This new and distinct variety is of Lilac Queen. This new and distinct variety is of dwarf compact habit and produces flowers of a pure lilac shade. The plants when in full bloom $\mathrm{r}$
a miniature candytuft. Pkt., $15 \mathrm{c} ;$ oz., $\$ 1.00$.

Iutescens. Creamy yellow. Pkt., 15c; oz., $\$ 1.00$

ALYSSUM SAXATILE COMPACTUM. "Gold Dust." Perennial 9 to 12 inches high. Excellent for beds and edgings. Sow in spring or early fall, in seed boxes and when large enough transplant. Pkt. 10c.

AMARANTHUS. Annual, ornamental follaged plants succeeding well in California, especially in the sum-
mer season. Sow the seed in spring in a seed box mer season. Sow the seed in spring

tricolor. "Joseph's Coat." Leaves red, yellow and green, height 3 ft. Pkt.. 10c.

ANCHUSA CAPENSIS. "Cape Alkanet." Annual $1 \frac{1}{2}$ to 2 feet high, of easy culture; flowers forget-menot blue. Pkt. 15c.

ANCHUSA. Italica, Dropmore. See page 6

ANTIGONON LEPTOPUS. "Rosa de Montana." A beautiful perennial climber, producing immense clusters of rose-colored flower-bracts. Sow in pots as early as possible and afterwards transplant. Pkt. 15c.

early as possible and afterwards transplant. Pkt. 15c. ing the first season from seed and generally treated in California as an annual. Showy plants for borders or large beds.

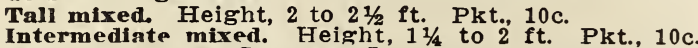
Intermediate mixed. Height

AQUILEGIA. "Columbine." Magnificent perennial plants growing from 2 to $3 \mathrm{ft}$ high and flowering in spring and early summer. The seed should be sown in spring in seed pans or boxes and afterwards transplanted to the open ground. They succeed best in a molst shady situation.

californiea hybrida. Very large yellow flowers with californiea hybrida. Very large yellow flowers chrysantha. Rich canary yellow. Pkt. 15c. coerulea. (Rocky Mountain Columbine), pale blue and white. Pkt. $15 \mathrm{c}$.

Long Spurred Hybrids. See Novelties, page 5.

ARCTOTIS GRANDIS. Aniual forming large, bushy. much branched plants, 2 to 3 feet high. Flowers large, white on the upper surface, the reverse of petals pale lilac-blue. Of easy culture and remark. ably free flowering. Pkt. 10c.

AURICULA. Perennial, 6 inches. Sow in seed pans and keep in house or frame; can be grown as a po plant or planted out in sheltered border. Seed saved from splendid collection of mixed sorts. Pkt $25 \mathrm{c}$.
A USTRALIAN PEA VINE. (Dolichos lignosus.) A very rapid growing vine, with pretty follage and rose and purple pea-shaped flowers. Valuable for covering up fences quickly; stands the heat well. hours before sowing soaked in hot water about 12 ing. Pkt., $10 \mathrm{c}$

ASTER. A popular annual, largely grown for cut flowers; also for beds, etc. Sow the seed from March to May in seed pans or boxes, and when large enough transplant to rich, well worked soil.

American Beanty. See Flower Seed Novelties, page 5 King. A large late flowering variety in great demand for cutting. The plants are of upright habit $11 / 2$ to 2 feet high, producing large double flowel: white, rose, crimson, lavender, violet, or mixed. Each, per pkt., $10 \mathrm{c}$; $1 / 4-\mathrm{oz} ., 50 \mathrm{c}$.
Crego Giant. See Flower Seed Specialties, page 5.

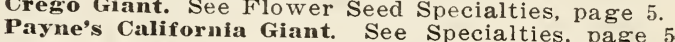
Payne's California Giant. See Specialties, page
Payne's Single Comet. See Specialties, page 5.

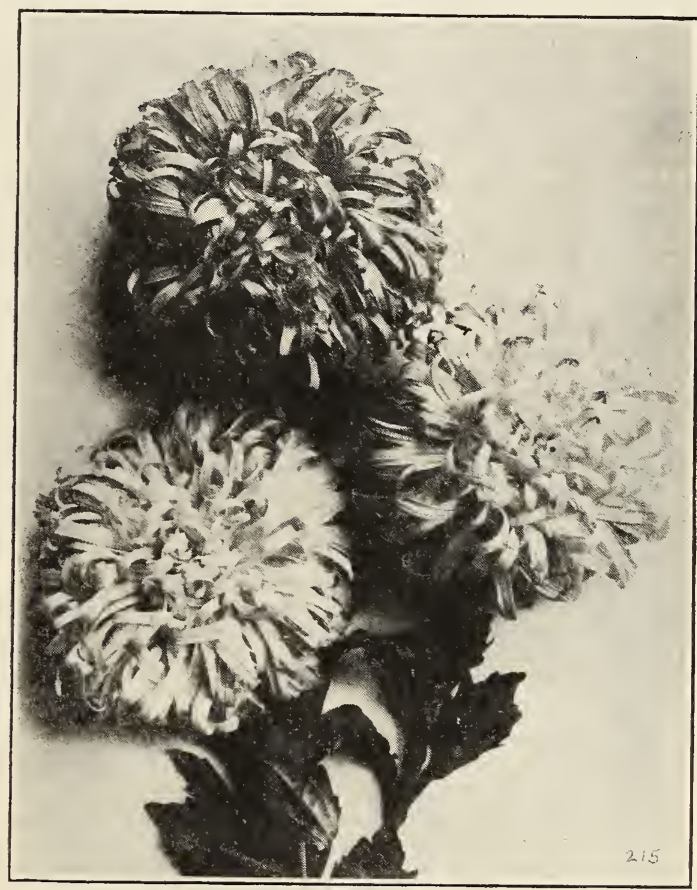

Crego Giant Aster

BALSAM. "Touch-me-not." Annual 1 to $11 / 2$ feet high Valuable for summer flowering. Sow the seed in boxes in early spring and afterwards transplant to beds of rich, well prepared soll.

Camellia-flowered. Double mixed. Pkt. 10c.

BARTONIA AUREA. Annual 1 to $1 \frac{1 / 2}{2}$ feet high. Large golden yellow flowers opening during the sunshine.

BEGONIA TUBEROUS-ROOTED. Beautiful perennia plants blooming the first season if sown early. Much used as pot plants; also for planting out in sheltered places. The seed should be sown in well drained seed pans, using a mixture of loam, leaf-mould and sand; press down firmily, sow the seed on the surface and do not cover, but press firmly with the hand; water with a fine spray. When the plants are large enough, pot off into small pots. Single varieties. Splendid mixed. Pkt. 50c. 
BEGONIA EVER-BLOOMING BEDDING VARIETIES. Perennials flowering the first season from seed. Very popular bedding plants dolng well in the full sunilght, also in shady and partially shady situasunlight, also in shady and partially shady situations, flowering for a long period. The plants grow about 1 foot high, forming dense, compact bushes, flowers. They are also admirable for pot culture or window boxes. Sow the seed the same as the tuberous rooted begonias.

gracllis. Delicate rose-color. Pkt. 15c.

Primadonna. Pale rose, large flowers. Pkt. 25c.

luminosa. Deep flery scarlet, very fine. Pkt. $25 \mathrm{c}$.

Vernon. Rich orange, dark red follage. Pkt. 15c.

Bellis Perennis. "Double Daisy." Perennial, but flowering the first season from seed. Favorite plant for edgings, low beds, etc. Height 6 inches.

Fine mixed. Pkt., $10 \mathrm{c}$.

Iontrosa. A new strain of strong, robust growth with abundance of imense very double flowers. Rose, red, white or mixed. Each, per pkt. $15 \mathrm{c}$.

BIDENS DAHLIOIDES. See Novelties, page 6.

BRACHYCONE IBERIDIFOLIA. "Swan River Dalsy." Annual 1 to $1 \frac{1}{2}$ feet, forming a close, compact plant with immense numbers of large single blue or white flowers, in bloom nearly all the year.

Blue. Pkt., 10c. Mixed. Pkt., $10 \mathrm{c}$.

BROWALLIA ELATA. Annual, 1 to $1 \frac{1}{2}$ feet high. A charming plant for beds and borders, with rich blue flowers, especially valuable in California for winter and spring blooming. Sow the seed in August or and spring blooming. Sow the seed in August or

CALCEOLARIA HYBRIDA GRANDIFLORA. A magnificent greenhouse perennial, blooming the first season. Large pocket-like flowers of the most brilliant shades of yellow, maroon, crimson, etc., spotted and blotched in the most unique fashion. The strain offered here is from one of the most celestrain offered here is from one of the most celequality. Sow in August or September in seed pans quality. Sow in August

Large flowered. Tigered and spotted. Pkt.. 50c.

CALENDULA OFFICINALIS. "Pot Marigold." Annual, 1 foot. The "Marygold" of Shakespeare. Exceedingly showy and free flowering plants of easy ing nearly all the year and most valuable for large ing nearly all the year and most valuab

Meteor. Yellow, striped orange. Pkt., 10c; oz., $40 \mathrm{c}$. Orange King. Deep orange. Pkt., $10 \mathrm{c} ;$ oz., $50 \mathrm{c}$. Lemon Queen. Sulphur yellow. Pkt., 10c: oz., $40 \mathrm{c}$. The Ball. See Flower Seed Specialties, page 6 .

CALliopsis. Annual, \& to 3 feet. Showy and free flowering plants of easy culture, doing best in a sunny situation and blooming for a long period. Flowers large, are splendid for cutting purposes. bicolor. Golden yellow with black centers. Pkt., $10 \mathrm{c}$; oz., $50 \mathrm{c}$.

Golden Wave. Deep golden yellow. Pkt., 10c; oz., $50 \mathrm{c}$. Fine Mixed. ...Pkt., $10 \mathrm{c}$; oz., $40 \mathrm{c}$.

CAMPANULA MEDIUM. "Canterbury Bells." Biennial, $21 / 2$ to 3 feet. Old-fashioned favorite flowers of easy cultivation. The seed may be sown late in spring or early in fall, in seed beds or boxes, and when large enough, transplant to where they are to fower. The pl.

Calreanthema. "Cup and Saucer Canterbury Bells." Calycanthema. "Cup and Saucer Canterbury Bells." Differs from the ordinary type in having an extra giving the appearance of a cup and saucer.

Cup and Saucer, Blue, Rose, White or mixed. Each, per pkt., $15 \mathrm{c}$.

Single, Blue, Rose, White or Mixed. Each, pkt., 10c. Double, Blue, Rose, White or Mixed. Each, pkt., $15 \mathrm{c}$

CANDYTUFT. Old-fashioned free nowering annuals growing 1 to $11 / 4$ feet high, very desirable for borders and masses.

Carmine. Bright rosy carmine. Pkt., 10c; oz., 50c.

Crimson. Dark crimson. Pkt., 10c; oz., 500.

Empress. White, long spikes. Pkt., $10 \mathrm{c}$. Oz, $80 \mathrm{c}$

Flesh Pink. A beautiful shade. Pkt., 10c; oz., $50 \mathrm{c}$ Lilac. Rosy lilac. Pkt., $10 \mathrm{c}$; oz., $50 \mathrm{c}$

Rose Cardinal. Pkt., $10 \mathrm{c}$; oz., $60 \mathrm{c}$.

Choice Mixed. Pkt., $10 \mathrm{c}$; oz., $40 \mathrm{c}$.

New Dwarf. Crimson, Flesh color, Rose, Lilac White or Mixed. Each per pkt., 15c: oz., $\$ 1.50$.

CANNA. Perennial, 3 to 6 feet high. Most effective plants for massing in large beds or for borders. making a great display of color. The plants bloom from early spring till late in the fall and the large. from early spring till late in the fall and the large. heavy, handsome foliage. Soak the seed in hot water

a few hours before sowing.

CARDINAL CLIMBER. See page 6.
Carnation. Perennial, $1 \frac{1}{2}$ to 2 feet high. Well known favorite flowers much used for high. Well poses. Sow in seed pans or boxes, and when large enough, pot off and afterwards transplant to the enough, pot off and afterwards transplant to the year; as they bloom they should be carefully marked, year; as they bloom they should be carefully marked. saving only the best double flowered ones and
carding the small and single flowered plants.

Marguerite. Scarlet, white, Yellow or Mixed. Each per pkt. 10c.

Perpetual or Tree, fine mixed. Pkt., $25 \mathrm{c}$.

Redondo. Choice mixed. Pkt., 15c

Carnation, Chabaud's Giant. See page 6.

CELOSIA CRISTATA. "Cockscomb." Annual, 1 loot high. Valuable as pot plants; also very effective for large beds and borders. They succeed best in a rather light, warm soll. The seed can be sown early in spring in seed pans or boxes and afterwards potted or transplanted to the open ground where they are to flower.

Glasgow Prize. The finest strain; combs of deep crimson color and immense size. Pkt., $15 \mathrm{c}$.

Fine mixed. Pkt., $15 \mathrm{c}$.

Celosia Plumosa. "Feathered Cockscomb." Annual, 2 to 3 feet high. Magnificent plants for large beds or groups. Producing large plume-like flowers, which can be cut and dried for winter bouquets. The seeds should be started in the same way as the other "Cockscombs" mentioned above. pyramidalis Thompsoni. Plumes of the most brilpkt. $10 \mathrm{c}$.

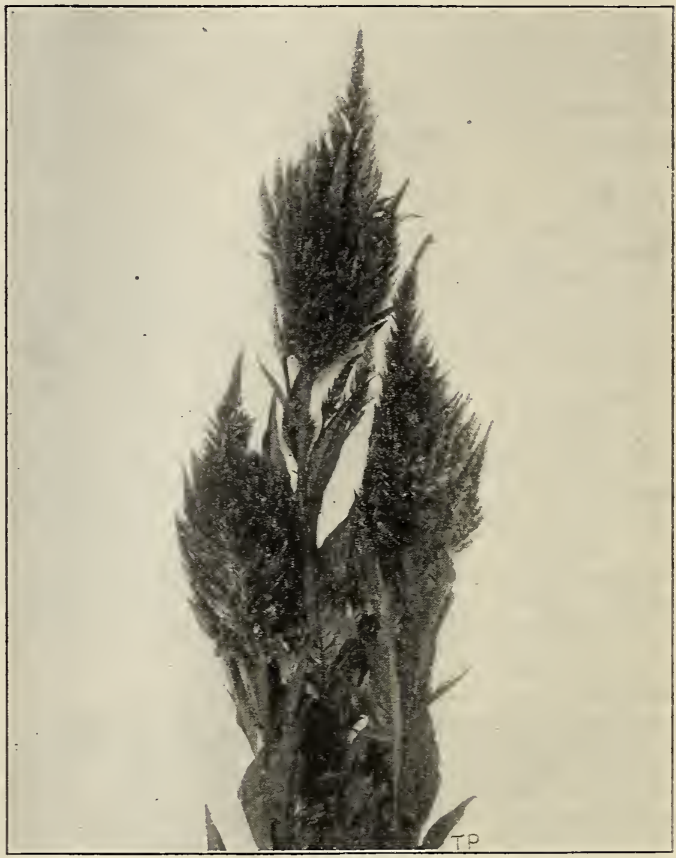

Celosia Pyramidalis Thompsoni

CENTAUREa CANDIDISSiMa. "Dusty Miller." Perennial, 1 to $11 / 2$ feet. A beautiful plant with white silvery leaves and used for beds and edgings. The seeds should be sown in seed boxes and afterwards transplanted. Pkt., 10c.

OENTAUREA IMPERIALIS. "Royal Sweet Sultan." Annual, 2 to 3 feet. A great improvement on the old strain of "Sweet Sultan": flowers resemble the "Cornfor florists' use, lasting a long time when cut.

Giant Amaranth Red. New, Pkt., 10c; oz., $\$ 1.00$.

Giant Brilliant Rose. Pkt. $10 \mathrm{c}, 0 z . \$ 1.00$.

Giant Delicate Llac. Pkt. $10 \mathrm{c}$, oz. $\$ 1.00$.

Giant Deep Lavender. Pkt. 10c, oz. $\$ 1.00$.

The Bridegroom. Hellotrope. Pkt. 10c, oz. $\$ 1.00$.

Giant White. Pkt. $10 \mathrm{c}, 0 z$. $75 \mathrm{c}$.

Giant Purple. Pkt. $10 \mathrm{c}$, oz. $75 \mathrm{c}$

Glant Rose. Pkt. 10c, oz. $75 \mathrm{c}$.

Glant Mixed. Pkt. $10 \mathrm{c}, 0 \mathrm{z} .75 \mathrm{c}$

unaveolenn. "Yellow Sweet Sultan." Annual, 11/ to 2 feet high. Flowers beautiful sulphur yellow. Largely grown for cut flowers. Pkt. 10c. 


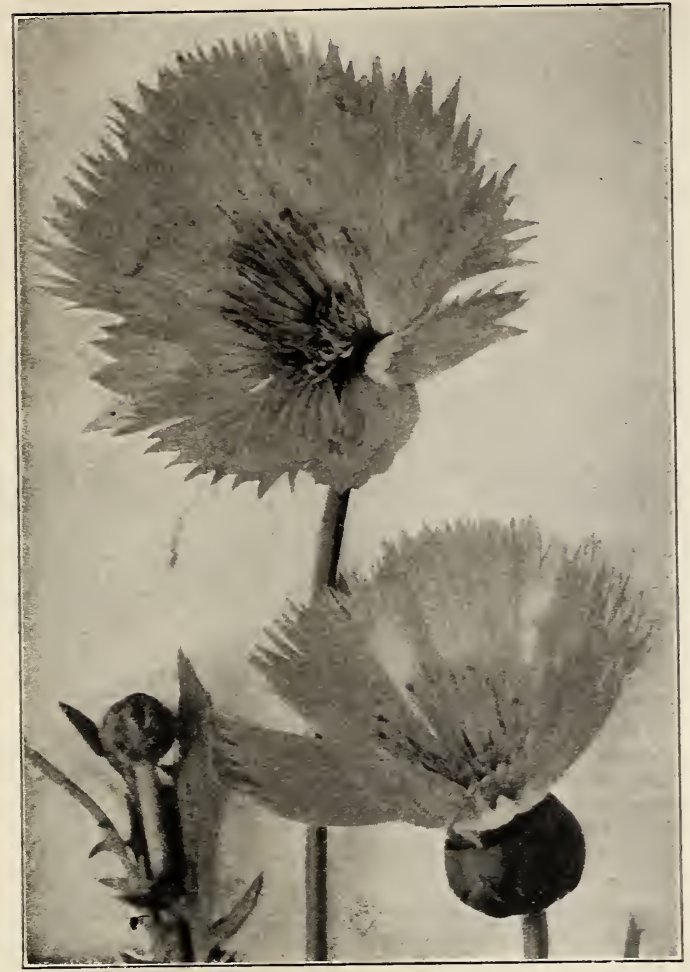

Centaurea imperialis

CFNTA UREA CYANUS. "Cornflower." Annual, $11 / 2$ to 2 feet high. A well-known annual, much used for bedding and borders, giving a wonderful show of color during Spring and Summer. Very fine for cut flowers and worthy of a place in every garden.

Double Blue. Pkt., 10c; oz., 70c.

Double Rose. Pkt., $10 \mathrm{c}$; oz., $70 \mathrm{c}$.

Double Mixed. Pkt., $10 \mathrm{c}$; oz., $60 \mathrm{c}$

CHINESE WOOL FLowER. See Novelties, page 6 .

CHRYSANTHEMUM. Annual varieties 1 to 3 feet high. Very showy for beds and also useful for cut flowers.

Northera Star. Large, white with soft yellow zone and dark eye. Pkt., $10 \mathrm{c}$.

Morning Star. Beautiful pale yellow. Pkt., 10c.

Evening Star. Golden yellow, large. Pkt., $10 \mathrm{c}$

Burridgeanum. White and red. Pkt., $10 \mathrm{c}$.

W. E. Gladstone. Rich crimson. Pkt.. $10 \mathrm{c}$.

Single Mixed. Pkt., $10 \mathrm{c}$; oz., $50 \mathrm{c}$.

Coronarium. Double yellow. Pkt., 10c.

Coronarium album. Double white. Pkt., 10c.

CHRYSANTHEMUM JAPONICUM. Perennial, 3 to leet. Well known plants, flowering in the fall and early winter. Seed should be sown in seed boxes early in the spring, and when large enough transplanted to the open ground. The plants will bloom the following fall.

Hybrids. Fine mixed. Pkt., 15 c.

CHRYSANTHEMUM FRUTESCENS. "White Marguerite." Perennial, 3 to 4 leet high. A well-known flower. Sow the seed in the same way as the Japan. ese varieties. Pkt., $10 \mathrm{c}$.

OINERARIA HYBRIDA GRANDIFLORA. Biennial, but treated as an annual in California. Height $1 \frac{11}{2}$ to 2 feet. Magniflcent plant for pot culture in green houses, or may be planted out in sheltered and houses, or may bituations. Sow the seed in Aug. partially shamber in seed pans, and as soon as large ust or September in seed pans, and as soon as large enough pot off into small pots and afterwards transfer to larger pots as required. The strain I am offering is the very best, procured direct from may be relied upon to produce large flowers of the most exquisite colors. Pkt., 50c.

Separate Colors. See Flower Seed Specialties, page 6 . stellata. See Flower Seed Specialties, page 6.
Crarkis. Annual, 2 to 1 feet high. Free flowering and of easy culture.

elegans. Fine mixed. Pkt., 10c; oz., 40c.

elegans rosea. Rose pink. Pkt. $10 \mathrm{c}$

elegans, Salmon Queen. Double, salmon pink $10 \mathrm{c}$

elegans, Scarlet Queen. Double scarlet. Pkt. 10c pulchella. Red. Pkt., 10c.

CLIANTHUS DAMPIERI. "Australian Desert Pea." Perennial, \& feet high. Bearing clusters of drooping pea-shaped flowers, 3 inches or more in length, of a brilliant rich scarlet color marked with a large black blotch in the center. The plants prefer a dry, sunny situation. Pkt., 15c.

puniceus. "New Zealand Glory Pea." Perennial, 1 feet; large bunches of showy red flowers. Pkt., 10c.

COBAEA SCANDENS. Perennial climbing vine attain. ing $a$ helght of 30 feet or more and blooming freely the first season. Valuable for covering trellises, arbors, etc. Large bell-shaped flowers. Sow the seed early in the spring in seed boxes, and as soon as large enough transplant Pkt., 10c.

ColeUs. Perennial, $1 \frac{1 / 2}{\text { to } 2}$ leet high. Magnificent foliage plant. For pot culture or for planting out foliage plant. For pot culture or for planting out seed pans, covering very lightly, and as soon as large enough pot of into small pots.

New large-leaved varieties. The finest strain procurable. Producing large leaves of the most brilliant and showy colors. Pkt., 25c.

Fine mixed. Pkt., $15 \mathrm{c}$.

COLLINSIA BICOLOR. "Innocence." Annual, 1 to feet high. Of slender, graceful habit, with bright green foliage. Flowers in clusters regularly disposed, suggesting rows. Upper lip white or lilae, lower rose-purple. Pkt., $10 \mathrm{c} ; 0 z ., 35 \mathrm{c}$; 1b., $\$ 4.00$.

CONVOLVULUS MAJOR. "Morning Glory." Annual climbing vine attaining a helght of about 15 feet Useful for covering fences, trellises, etc. Soak the seeds in warm water a few hours before planting. White, rose crimson, dark blue, or mixed. Each, per pkt., $10 \mathrm{c}$

minor. "Dwarf Morning Glory." Annual, 1 foot. Flowers similar to the "Morning Glory," but smaller and remaining open all day in fne weather. Very pretty for borders or grown in masses in beds. All pretty for borders or grown

mauritanicus. Perennial trailing plant. Valuable for rock work or hanging baskets. Flowers a rich shade of lavender. Soak the seeds a few hours in hot water before planting. Pkt., 15c.

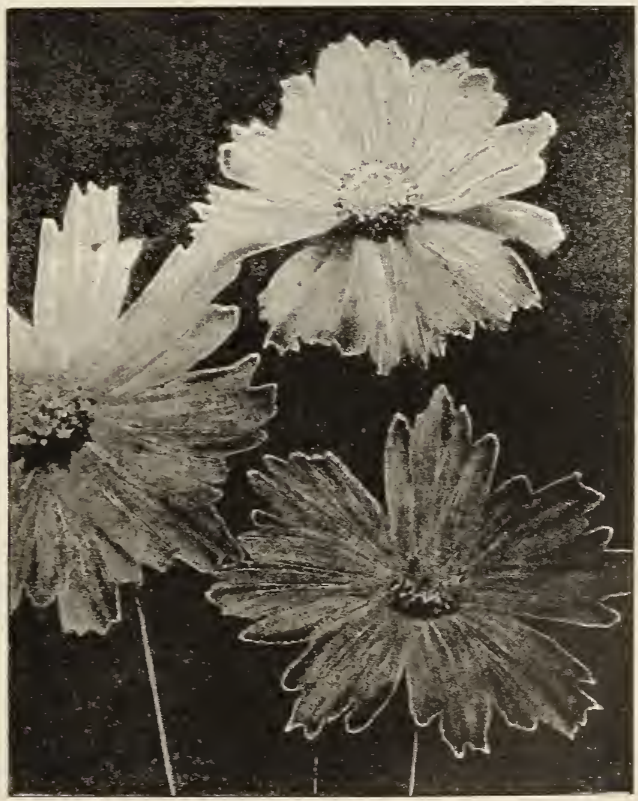

Coreopsis lanceolata COREOPSIS LANCEOLATA. Perennial, 2 feet high
Large, showy, bright yellow flowers produced in great abundance, giving a brilliant show of color when planted in masses; also very attractive when used as a border. Much used for cutting purposes. Pkt., 10c. 
CORNFlower. See Centa UREa.

CosMos. Annual, producing large single flowers much used for cutting purposes. The plants vary in helght according to the time of year at which they are planted. If sown in the spring they grow very planted. If sown ln the spring flow in the fall. tall, if the seed is sown in the fall, about October, but if the seed is sown in the rall, about they will flower in about 2 months and the plants will be dwarf, from $11 / 2$ to 2 feet high and are very pretty for massing in beds. Seed sown in Decem

Mammoth perfection, white, dark pink, crimson, or mixed. Each, per pkt, 10c: oz., $40 \mathrm{c}$.

Lady Lenox. Very large flowers; a lovely shade or Lady Link. Pkt $10 \mathrm{co}$, $50 \mathrm{c}$

Lady Lenox, White. Very large flowers, pure white. Pkt., 10c; oz., $50 \mathrm{c}$.

Anemone Flowered. See Novelties page 6.

CosMos KLONDYKE. Annual, 2 to 3 feet. Deep orange-colored flowers 2 to $21 / 2$ inches in diameter, blooming in the fall. Pkt., $15 \mathrm{c}$

CUCUMBER WILD. (Echinocystis lobata.) A quick growing annual vine for covering trellises, te. Pkt. $10 \mathrm{c}$.

CYClanen Persicum. Perennial, 8 to 10 inches. Charming plants with rich colored, fragrant flow. ers. Blooming in winter and spring. Generally grown as a pot plant. The seed may be sown in the spring or early in the fall in seed pans of rich soil mixed with leaf-mould and sand and potted on when large enough

cianterime Fine mirer Pkt, 950

Giant English. See Flower Seed Specialties, page 6 .

CYPRESS VINE. A popular annual climbing vine with delicate fern-like foliage and masses of small stardelicate flowers. Sow early in spring; soak the seed in warm water a few hours before sowing. Scarlet, white or mixed. Each, per pkt., $10 \mathrm{c}$.

DAISY. See BELLIS.

AHLIA. Perennial, 4 to 6 feet, flowering the first season from seed. Well known plants with large, showy flowers, useful for beds and masses. Sow the seed early in spring in seed boxes and afterwards transplant to the open ground. Dahlias like a rich soll with plenty of well rotted manure and shoul be watered freely. In raising Dahlias from seed many of them will come semi-double, although the seed is saved from the very best double varieties. The best varieties should be marked when in flower and at the end of the season the poor ones dis. carded and the better ones can be taken up and divided and again replanted.

Cactun. Double, with long polnted petals; seeds aved from one of the finest collections. Mixed colors. Pkt., $15 \mathrm{c}$.

Double, Large Flowered. Mixed colors, Pkt, 15c. Paeony Flowered. Large, mixed colors. Pkt. $15 \mathrm{c}$ gingle. All colors; splendid mixed. Pkt., $10 \mathrm{c}$.

DELPHINIUM. "Perennial Larkspur." Perennial, 3 to 5 feet high. Beautiful summer flowering plants with long spikes of showy flowers. Sow the seed in spring or early fall in seed boxes and afterwards transplant to open grounn

Belladonna. See Flower Seed Specialties, page 6 . Gold Medal Hybrids. Extremely large flowers in all the richest shades of blue. Pkt., 15c.

Blue Butterfly. Distinct varlety growing about 18 inches high, flowering first season from seed. Plants produce freely splkes of large, single, Salviahlup Antwars. Pkt. 15 .

Delphinium chinense, Tom Thumb. See page 7 . cardinale. "Scarlet Larkspur" A native Calleornia specles, with long spikes of scarlet flowers. Pkt., $10 \mathrm{c}$.

DIANTHUS CHINENSIS. Biennial, but generally treated as an annual; 1 foot high. Charming freeflowering plants with flowers of the most brilliant colors. Very effective for planting thickly in beds. chinensis. Fine mixed. Pkt., $10 \mathrm{c}$.

Heddewigt. Single fine mixed. Pkt., $10 \mathrm{c}$

Crimmon Belle. Single crimson. Pkt., 10c.

Eantern Queen. Single, marbled carmine-rose mauve and lilac. Pkt., $10 \mathrm{c}$

hybridum. Double mixed. Pkt., 10c.

laciniatus. Single fringed, fine mixed. Pkt., 10c. plamarias. Perennial, 1 foot high. A beautiful singlo pina. Flowers with fringed edge. white with

DIGITALIS. "Foxglove." Perennial, 3 to 5 leet. An old-fashioned flower with long suikes of tubular. shaped flowers. Sow the seed in spring or fall in seed pans and afterwards transplant.

gloxiniacfiora. Beautleully spotted. mixed. Pkt. 10c. The Shirley. See Flower Seed Novelties, page 7 .
DIMORPHOTHECA AURANTIACA. "African Orange Daisy." Annual, 12 to 15 inches high. One of the very best winter flowering plants yet introduced. By sowing the seed in September or October, it can be had in bloom as early as January and will flower continually until late spring or early summer. The marguerite-like blossoms, about two and a half inches in diameter, are of a unique, glossy orangegold, this brilliant coloring being rendered more cound us by the Hybrida. Splendid new hybrids, colors range from white, lemon yellow, golden yellow, orange to salmon. Pkt., $15 \mathrm{c}$.

ERYSIMUM PERofSKiANUM. Annual, 1 to $1 \frac{1}{2}$ feet high, resembles the wallflower and produces in winter and spring great quantities of orange colored flowers; effective in masses. Pkt., 10c; oz., 60c.

ERYNGIUM AMETHYSTINUM. "Sea Holly." Perennial, 2 to 3 feet, producing in summer quantities of summer or early fall in seed boxes and transplant. Pkt., $15 \mathrm{c}$

ESCHSCholtzia CALIFornica. "Callornia Poppy." Annual, 1 to $11 / 2$ feet high. A well known native Yellow, orange, white, or mixed. Each, pkt., $10 \mathrm{c}$; oz., $35 \mathrm{c}$

Burbank's Crimson-flowering. Crimson. Pkt., $10 \mathrm{c}$. Rose Cardinal. White and rose. Pkt., 10c. Carmine King. Carmine rose. Pkt., 10c.

Golden West. Canary-yellow with orange blotch at base of each petal. Pkt., 10c.; oz., $40 \mathrm{c}$.

Mandarin. Inside of petals rich orange, outside orange-scarlet. Pkt, 10c.

Mikado. Brilliant orange-crimson. Pkt., 15c.

Orange Flame. New, orange scarlet. Pkt., $25 \mathrm{c}$.

Scarlet Beauty. New, deep scarlet. Pkt., 25c.

Tango. New, bronzy red and terra cotta. Pkt., 25c. The Geisha. Gold and orange crimson. Pkt., 15c. Vesuvius. Wallflower red. Pkt., $15 \mathrm{c}$.

New Hybrids mixed. Pkt., $15 \mathrm{c}$.

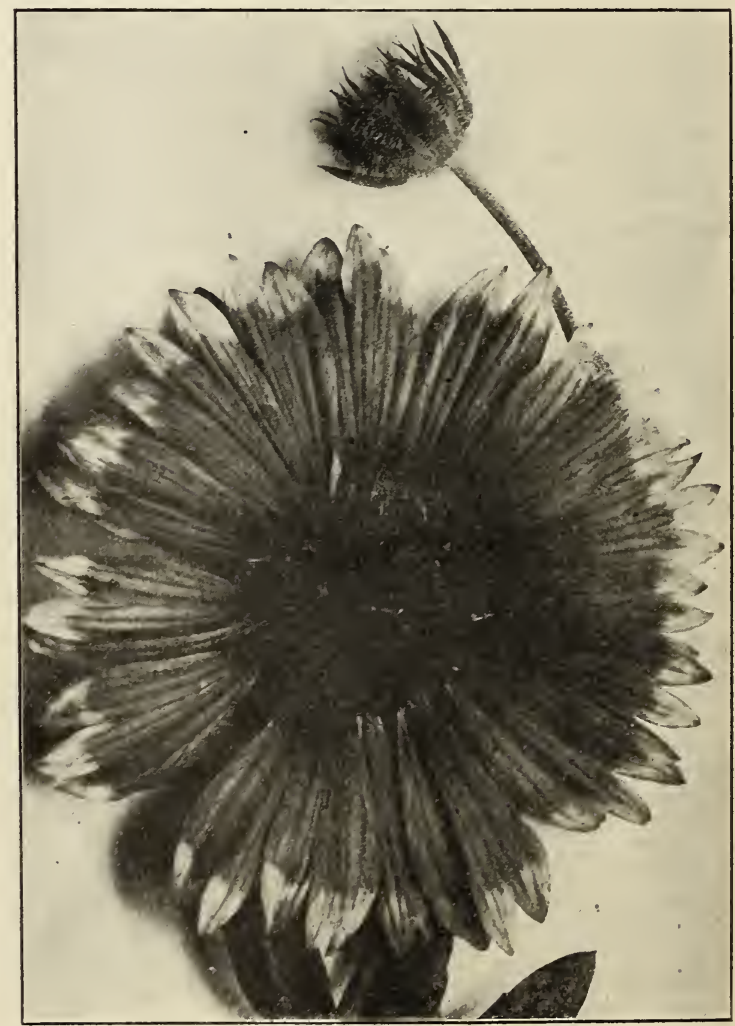

Gaillardia grandiflora 


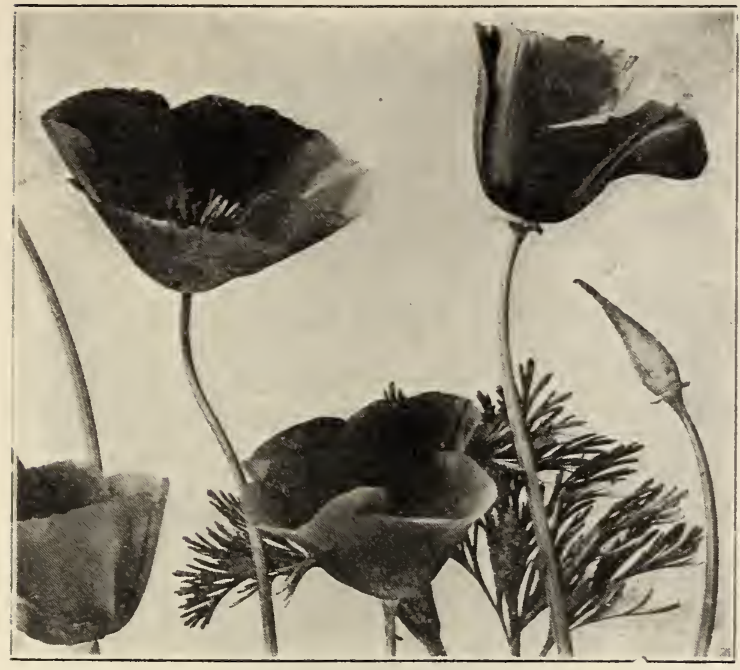

Eschscholtzia californica. "California Poppy"

FrEEsi. See Flower Seed Specialties, page $i$.

GAILLARDI. I'ICTA. Annual, 1 to $1 \frac{1}{2}$ feet high. Bright colored flowers in great profusion; fine for bedding or border. Sow in early spring.

picta. Crimson and orange. Pkt.. 10c.

picta Lorenziana. Double mixed colors. Pkt., $15 \mathrm{c}$.

GAILLARDIA GRANDIFLORA. Perential $1 / 1 / 2$ Papt Tery popular on account of its large flowers on long stems. Fine for cut flowers and especially attractive in large masses. Large flowered varieties, fine mixed.
Pkt., 10c.

GERANIUM. Well known perennial, single varieties. splendid mixed. Pkt., $15 \mathrm{c}$.

GERBERA. See Flower Seed Specialties, page 7.

GEUM COCCINEUM, Mrs. Bradshaw. Splendid perennial which blooms for the greater part of the year Grows $1 \frac{1}{2}$ to 2 leet high and produces a profusion of large double bright scarlet flowers. Pkt. 15c. Lady Stratheden. See Flower Seed Novelties, page $;$.

GILIA TRICOLOR. "Bird's Eyes," Annual, 9 inches to 1 foot high. Flowers pale lilac, yellow toward the center, with five purple spots. Charming comthe center, with five purple spots. Charming
bination of colors. Pkt., 10 c.; oz., $40 \mathrm{c}$; $1 \mathrm{~b}$., $\$ 5.00$.

GLOXINIA HYBRIDA. Beautiful perennial greenhouse plant, height about 8 inches, with large handsome foliage and immense trumpet-shaped flowers which are of a texture like velvet, of the most brilliant shades of violet, purple, crimson, scarlet, pink and lavender. Often burple, crimson, scarlet, pink ted. Sow the seed in February or March in seed pans of light soil mixed with leaf-mould in seed pans of light soil mixed with leaf-mould. Do not cover the seed, but sow on the surface and press
down firmly with the hand and water with a fine spray. Keep in a greenhouse; when plants are large enough, pot off as required. All colors, splendid mixed. Pkt., $25 \mathrm{c}$.

GODETIA. Annual, 1 to 2 reet high, with large, showy flowers. Especially valuable for sowing in partially shady places.

Duchess of Albany. Pure white. Pkt. $10 \mathrm{c}$

Crimson Glow. Rich deep crimson Pkt.

Lady Albemarle. Large, brilliant crimson. Pkt., $10 \mathrm{c}$. Lady Satin Rose. Bright carmine. Pkt., $10 \mathrm{c}$.

Rosy Morn. Double, deep rose. Pkt., $15 \mathrm{c}$.

Hybrids, Mixed Culors. Hkt., 10c: oz, $50 \mathrm{c}$

GOMPHRENA GLOBOSA. "Globe Amaranthus." Annual, $1 \frac{1}{2}$ to 2 leet high. Producing numerous flow ers resembling clover heads, which are cut and dried as an everlasting flower. White, pink, purple and

GYPSOPHILA ELEGANS. Annual, $1 \frac{1 / 2}{2}$ to 2 leet high. Much used for bouquets for mixing with carnations and other flowers. Flowers small, white; blooming best in the winter season. Pkt., 10c; oz., 40c.

paniculata. Perennial, 2 leet high. Flowers smaller than the preceding. White and used for bouquets. Blooms during the summer season. Pkt.. $10 \mathrm{c}$.

Double Snow White. A new variety producing about 50 per cent double flowers. Pkt., 25c.
HELIANTHUS. "Sunflower." Annual, 6 to 7 leet. Well known showy plants for summer flowering. Sow the seeds in the spring in the open ground where they are to remain and flower.

Chrysanthemum Fowered, Double. Very large, perfect flowers resembling giant chrysanthemums. Flowers on long stems, golden yellow and double. Flowers

New Red Sunflower. Flowers vary greatly in size, from 4 to 8 inches across. Color of the flowers also varies, some are solid red, others with petals tipped and other pleasing combinations of red and gold. Planted for a background or a temporary hedge, they are very showy Pkt 150 .

cucumerifolius, Stella. Single, extra fine. Pkt., 10c. IIniature Excelsior hybrids. Single, light or dark yellow with narrow zones of blood red, purple or brown, mixed. Pkt., 15c.

angustifolius. "A utumn Glory." Produces great quantities of single yellow flowers in fall. Pkt., $15 \mathrm{c}$.

HELICHKXSUM MUN'TKUSUM. "Straw Flower." Annual, 2 to 3 feet. A well known "everlasting" flower. Double, fine mixed. Pkt., $10 \mathrm{c}$.

HELIOTROPIUM. Perennial, 4 to 5 feet. A lavorite flower on account of its delighteul fragrance. Sow the seed in the spring in seed boxes and transplant. Large flowered varieties mixed. Pkt.. $10 \mathrm{c}$.

HEUCHERA SANGUINEA. "Coral Bells." Perennial with heart-shaped leaves from which rise numerous slender graceful stems about 1 foot high bearing quantities of small coral-red bell-shaped flowers. Very effective for borders and rock gardens. Sow in seed boxes early in the fall and transplant. Pkt., $15 \mathrm{c}$.

HOLLYHOCK. Perennial, 6 leet high. An old-lashloned favorite flower. Sow the seed in boxes late in summer and transplant. The plants will bloom the following summer.

Chater's superl) strain, finest double. Newport pink, salmon, rose, scirlet, yellow or mixed. Each, per pkt., $15 \mathrm{c}$.

single. Choice mixed. Pkt. $10 \mathrm{c}$.

HUMULU JAPONICUS VARIEGATUS. "Japanese Hop." A beautiful annual climbing plant. Leaves mop. A beautiful annual climbing plant. Leaves marbled and splashed with white on light and dark green ground. Sery efrective lor screens, arbors, warm and settled. Pkt., $10 c$.

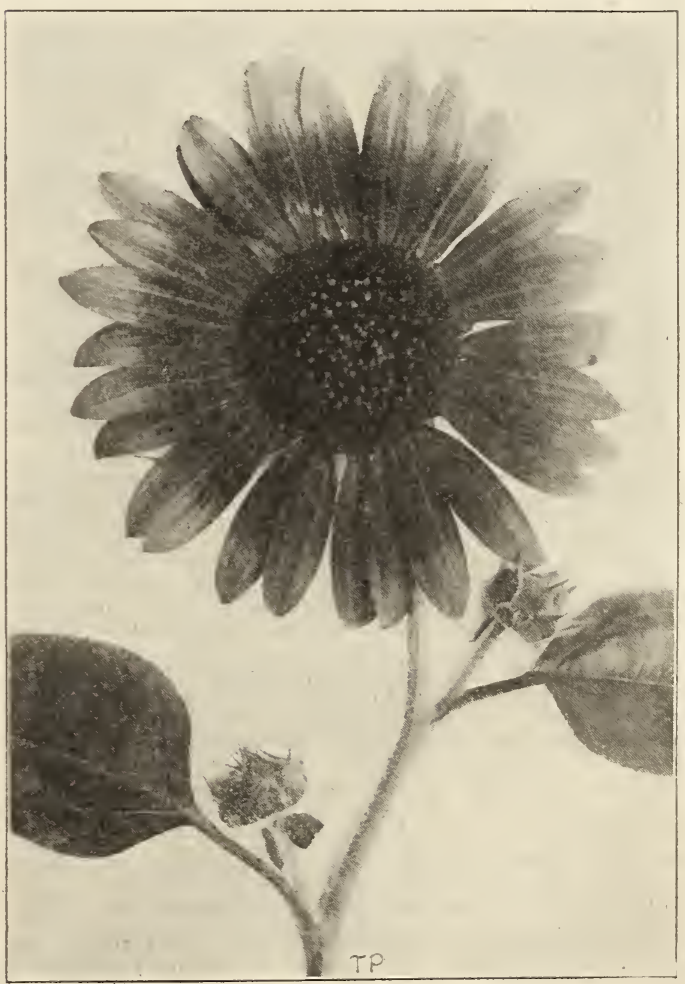

Helianthus, New Red Sunfiower 
huNNEMANNIA Fumariageotia. "Mexican Poppy." Perennial, 2 to 3 feet. Large flowers resembling the Californla poppy, but more bowl-shaped and of light canary-yellow color. Very free flowering and especially valuable for cutting purposes, the blooms lasting a long time in water. Blooms freely the lasting a long time in water sown in the spring greater part of the season. or summer will bloom with.

IPONOEA LEARI. "Blue Dawnflower." Perennial ONOEA LEARI. to 40 feet. Ilkes a warm, sunny climbing vine, 30 to 40 feet. Likes a warm, sunny situation. Soak the seed in hot water a few hours before planting and sow in spring

is warm and settled. Pkt., 15c. grandifiora alba. "White Moonfow wite erannial climbing vine, 15 to 20 peet. Large white, Iragrant flowers 5 inches in diameter. Treat the seed the game as the above variety. Pkt., 15c. Heavenly Blue. Annual, 15 reet. Flowers large, skyall. Treat the seed the same as the above. Pkt., $10 \mathrm{c}$. imperialis. "Imperial Japanese Morning Glory." Annual, 15 to 20 feet. Flowers large, varying in color from pure white to carmine, through blues and purples of every shade to almost black. Pkt., 10c.

KOCHIA TRICHOPHYLLA. "Summer Cypress." Annual, 3 to 4 feet high. Forms very decorative, compact bushes with fine light green follage, which turns deep red in the fall. Very ornamental for planting as a background or temporary hedge. Sow in spring. Pkt. $10 \mathrm{c}$.

JACOBAEA. (Senecio elegans.) Free flowering annual, 1 to $11 / 2$ feet high producing dense heads of small double flowers; very desirable for cutting. Flesh color, Red, Lilac, or mixed. Each, Pkt.,15c.

LAKKSPUR. Annual, 3 feet high. Free flowering plants. Useful for beds and also for cutting

tall stock-flowered, branching double. Azure blue, dark blue, shell pink, lustrous carmine, white or mixed. Each, per pkt., 10c; oz., $60 \mathrm{c}$.

Tall, Exquisite Pink. New. Pkt., $25 \mathrm{c}$.

dwarf rocket. Height 2 feet. Mixed. Pkt., 10c.

LATHYRUS LATIFOLIUS. "Everlasting Pea." Perennial vine, 4 feet. Free flowering plants, mixed colors. Pkt. 10c,

White Pearl. Very large, snowy white blossoms on long stems. Very hardy and grows quickly. Pkt. $15 \mathrm{c}$.

Plnk Beauty. Large flowers, bright pink. Pkt. 15c.

LAVATERA TRIMESTRIS. Annual, 3 feet high, producing large saucer-shaped flowers. Sow in spring. Rose color or white. Each, per pkt., $10 \mathrm{c}$.

LINARIA CYMBALLARIA. "Kenllworth Ivy." A charming little perennial tralling plant. Useful for baskets, rock work, etc. The flowers are like a minlature Snap-Dragon; color lavender and purple, and contrast well with the small ivy-shaped leaves. Pkt., $15 \mathrm{c}$.

LINARIA MAROCCANA. Annual, 12 to 15 inches high Very pretty in masses. Mixed hybrids. Pkt., 10c; oz. $\$ 1.00$.

LINUM GRANDIFLORUM RUBRUM. "Scarlet Flax." Annual, 1 to 2 feet high. Very effective for planting in masses in large beds; also for sowing broadcast on waste ground. Pkt., $10 \mathrm{c}$; oz., $35 \mathrm{c}$. perenne. Perennial, 1 to $1 \frac{1}{2}$ feet, bright blue flowers. Pkt., $10 \mathrm{c}$.

LOBELIA. Annual, 4 to 6 inches, forming compact, free flowering plants much used for edgings, etc. Sow the seed in February in seed pans of fine light soll. Do not cover the seed, but sow on the surface and press down firmly with the hand and water with a fine spray. As goon as large enough to be handled, the seedlings may be pricked out into shallow boxes and afterwards transplanted to the open ground.

Crystal Palace compacta. Rich deep blue, dark follage. The finest dark blue for bedding. Pkt., 10c.

Light Blue. Compact growing. Pkt., 10c.

erinum xpeciona. Dark blue, dark follage. Tralling. Useful for hanging baskets. Pkt., 10c.

hybrida Sapphire. New, deep blue, with white eye Of tralling habit, valuable for hanging baskets and window boxes. Pkt.. $15 \mathrm{c}$.

LOBELIA CARDINALIS. Queen Victoria. Perennial 3 feet. Dark bronze follage and brilliant scarlet flowers. Sow same as annual varieties. Pkt., 15c.

LOVE-LIES-BLEEDING (Amaranthus caudatus). Annual, 2 feet high, with large drooping panicles of blood-red flowers. Seed should be sown in the spring the plants bloom during summer. Pkt., 10c.

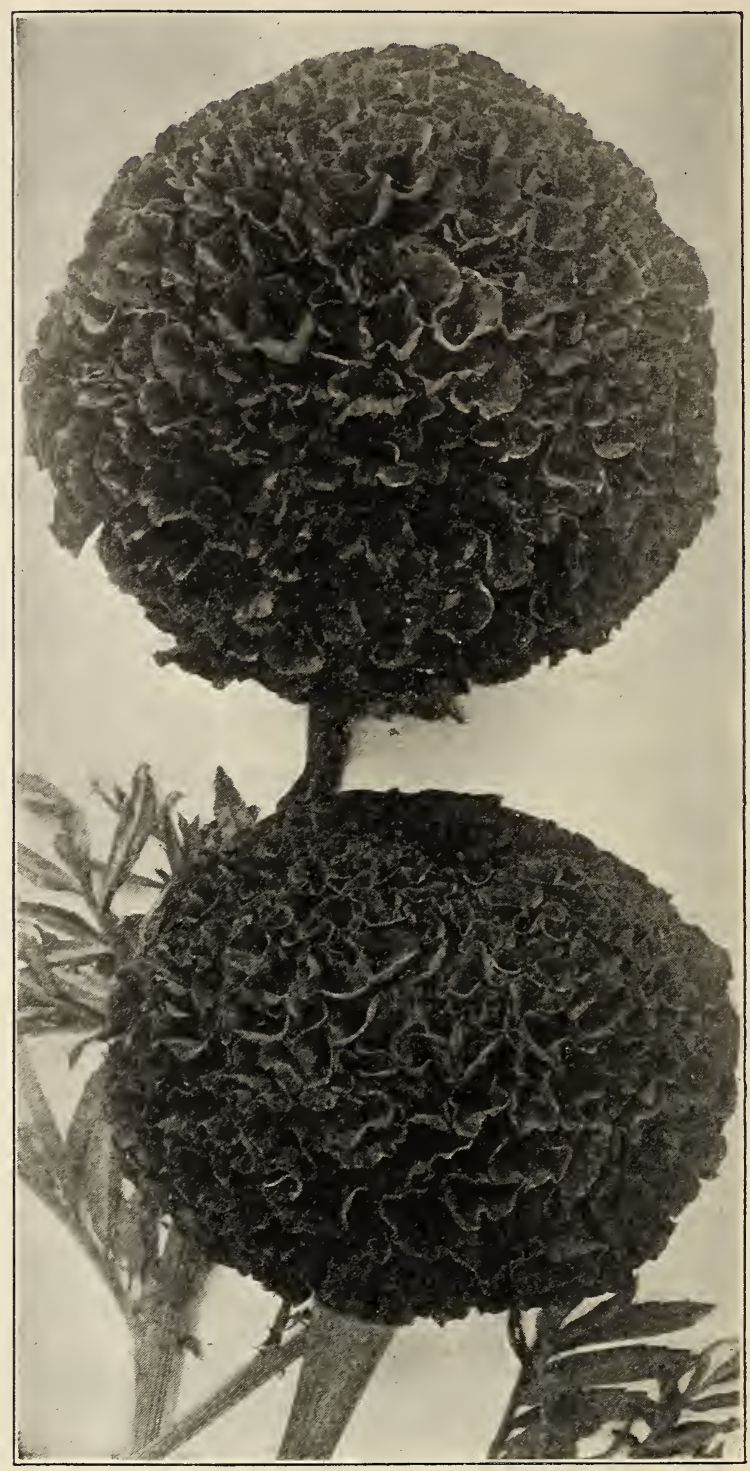

Afrlcan Marlgold, Orange Ball

LUPINUS, ANNUAI VARIETIES MIXED. 1 to 3 feet high. Well known free flowering plants. Pkt., 10c. nanus. Dwarf blue; useful for edging and borders. Pkt., 10c; oz., 40c.

Hartwegi. Annual 2 to 3 feet. Long spikes of large flowers. Sky blue, dark blue, pink, white, or mixed. Each, per pkt., 15c

LUPINUS ARBOREUS, SNOW QUEEN. Perennial, 4 feet. A magnificent variety, producing long spikes of pure white flowers. Sow in fall elther in the open ground where the plants are to remain, or in pots, and afterwards transplant. Plst., $15 \mathrm{c}$.

New Hybrids. A splendid new strain, producing large flowers in different colors. Pkt., $15 \mathrm{c}$.

polyphyllus roseus. Rosy pink, extra fine. Pkt., 15c. Paynel. See Flower Seed Novelties, page 7.

Malope GRANDiFlora PURPUREA. Annual, 2 feet high. Flowering well during the summertime. Large crimson flowers. Pkt., $10 \mathrm{c}$. alba. White. Pkt., $10 \mathrm{c}$.

MANDEVILLEA SUA VeOLENS. "Chill Jasmine." Perennial vine, 15 feet. Large white fragrant flower. Sow in spring in seed boxes and pot off when ready. Pkt., 15c. 
F A A towering in summer And arge, double and very showy. Sow in spring.

Lemon Ball. Soft lemon-yellow. Pkt., 15c; $1 / 2 \mathrm{oz}, 60 \mathrm{c}$. Orange Ball. Deep orange. Pkt., 15c; t/ oz., 60c Double fine mixed. Pkt., $10 \mathrm{c}$; $1 / 2 \mathrm{oz} ., 40 \mathrm{c}$.

MARIGOLD, FRENCH. Annual, 1 to 2 feet high. Sow in spring.

Gold triped. Very double; deep brownish-red striped with golden yellow. Pkt., 10c.

Double golden yellow. Pkt., $10 \mathrm{c}$.

Dwarf double mixed. Pkt., $10 \mathrm{c}$.

Legion of Honor. "Little Brownle." A compact crowing single variety. Golden yellow marked witb grape spot of crimson velvet on each petal. Pkt., $10 \mathrm{c}$.

MATRICARIA EXIMIA. "Feverfew." Annual, 1/2 feet of easy culture. Fine for cutting. Double white. Pkt., $10 \mathrm{c}$.

MA URANDiA. Perennial climber, 6 feet. Delicate foliage and pretty trumpet-shaped flowers. Sow early in oling and the plants will bloom the first season. Mixed colurs. Pkt., 10c.

MESEMBRYANTHEMUM. Dware, trailing, annual. Blooming during the summer. Sow the seed in spring in a warm, sunny situation.

plowers white. Foliage has the appearance of being coated with ice. Pkt.,10c.

MIGNONETTE. Annual, 8 inches to 1 foot high. An old-fashioned flower much prized for its fragrance. Large Flowering. Sweet scented. Pkt., 10c; oz., $30 \mathrm{c}$. Machet. Of dware pyramidal habit. Very eragrant. Pkt., 10c; oz., 50c.

Allen's Defiance. A large variety with immense spikes. Pkt., 10c; oz., 60c.

Goliath. Bright red, large spikes. Pkt., 10c; oz., $\$ 1.00$.

MIMosa PUdiCA. "Sensitive Plant." Annual, 2 leet. A curious plant with pinnate leaves which close up immediately when touched. Sow in seed pans early in spring. Pkt., 10c.

MIMULUS. Perennial plants of great beauty, succeeding best in a moist, shady place. Sow the seed in the fall in seed pans of light soll mixed with learmould; sow the seed on the surface and water with a fine spray. Pot off the plants when large enough, and later plant out in the open ground."

ticrinue grandifiorus. "Monkey Flower"” Helght lieet, spotted and blotched varieties, flne mized. $1 / 2$ reet,

cardinalls. "Scarlet Monkey Flower." Perennial, 1 to 3 feet. A beautiful native species with pale green leaves and bright scarlet flowers, with yellow throat. Pkt., $15 \mathrm{c}$.

monchatus. "Musk Plant." Fine for hanging baskets and pots. Small yellow flowers, fragrant. Pkt., 15c.

MINA LOBATA. Beautiful annual climbing vine at taining a height of 10 to 12 feet. Flowers in long. graceful spikes: color bright red, changing to orange and cream. Sow in spring in a warm, sunny situation. Pkt., $10 \mathrm{c}$

MIRA BILIS JALAPA. "Marvel of Peru" or "Fouro'clock." Free flowering annual of bushy habit, o'clock." Free flowering annual of bushy habit, growing 3 to 4 feet high and flowering thr
the summer. All colors mixed. Pkt., $10 \mathrm{c}$.

MOMORDICA BALSAMINA. "Balsam Apple." Annual climbing vine, 8 to 10 feet, with large leaves making a dense shade. The flowers are followed by curious a dense shade. The flowers are followed by curious the seed and its brillant carmine covering. Pkt., 10c.

MYOSOTIS. "Forget-me-not." Perennial, 6 to 10 inches, succeeding best in a shady, moist situation. inches, succeeding best in a shady, moist situation. plant. alnestris. Bright blue. Pkt., 10c.

Royal Bine. Indigo blue, extra fine. Pkt. 15c.

NASTURTIUM, TOM THUMB. Annual, 8 inches to 1 foot: useful for bedding and borders, flowering through the summer and also through the winter in locations where they are not cut by the frost.

Lady Bird. Orange-yellow, red spots. Plst., 10c. Ruby King. Light ruby-red. Pkt., 10c.

King Theodere. Almost black, dark foliage. Pkt., 10c. Golden King. Indian yellow, dark follage. Pkt., 10c. King of Tom Thumbs. Scarlet, dark follage. Pkt., $10 \mathrm{c}$ Empress of India. Crimson, dark follage; dwarf and compact; eftective for beds and edging. Pkt., 10c. compact; effective for beds and edging Yellow. Pkt., 10c.

A1l colors mixed. Pkt., 10c; oz., 20c; 1b., $\$ 2.00$.
NASTURTIUM TAIL. Climbing annual, 6 to 10 reet, of easy culture Useful for covering fences, trellises, etc. and also very effective when allowed to run on the ground.

Butterfiy. Sunflower yellow, spotted salmon pink. Pkt., $10 \mathrm{c}$.

Dunnett's Orange (Sunlight). Yellow. Pkt., 10c.

King Theodore. Almost black, dark foliage. Pkt.10c. Rose. Salmon rose. Pkt., $10 \mathrm{c}$

Scarlet. Bright scarlet. Pkt., $10 \mathrm{c}$

Crimson. Velvety crimson. Pkt., $10 \mathrm{c}$.

Fordhook Fashion. Terra cotta on yellow ground. Pkt., $10 \mathrm{c}$.

Moonlight. Creamy white. Pkt., 10c.

Edward otto. Brownish lilac. Pkt., $10 \mathrm{c}$.

Vemuvius. Salmon rose, dark follage Pkt. $10 \mathrm{c}$

Prince Henry. Yellow marbled with scarlet. Pkt., 10c.

Juplter. Very large, rich yellow. Pkt., $10 \mathrm{c}$.

Fine mixed. Pkt., 10c; 0z., $20 \mathrm{c} ; 1 \mathrm{~b} ., \$ 2.00$.

NEMESIA. See Flower Seed Specialties, page 7

NEMOPHILA. A beautiful native annual, 4 to 6 inches high and flowering in 8 or 9 weeks from the time of sowing.

Insigniø. "Baiby Blue Eyes." A delicate little plant; flowers clear azure blue. Pkt., 10c; oz., 35c; 1b., $\$ 4.00$.

maculata. White spotted with purple. Pkt., 10c: oz., $35 \mathrm{c}$; ib., $\$ 4.00$.

NICOTIANA. Annual, 2 to 4 feet. Sow the seed in the spring in seed boxes and transplant.

afinis. Large white, fragrant flowers, 3 inches across. Pkt., 10c.

Sanderac hybrids. Splendid plants, flowers in great variety of colors. Pkt., $10 \mathrm{c}$.

NIEREMBERGIA CALYCINA. Slender growing perennial plant, 1 to $11 / 2$ feet. Desirable for hanging boxes. Flowers white tinted with lavender. Pkt. 15c.

NIGELLA DAMASCENA. "Love-in-a-Mist." Annual; height $1 \frac{1 / 2}{2}$ feet, with finely cut foliage; curious looking flowers of a pale blue color.

Mlss Jekyll. Flowers of a beautiful corn-flower blue, fine for cutting. Pkt., $10 \mathrm{c}$.

OENOTHERA DR UMMOND. "Evening Primrose." Annual, 2 to 3 feet, with large yellow flowers, Succeeds well in a partially shaded place. Pkt., $10 \mathrm{c}$.

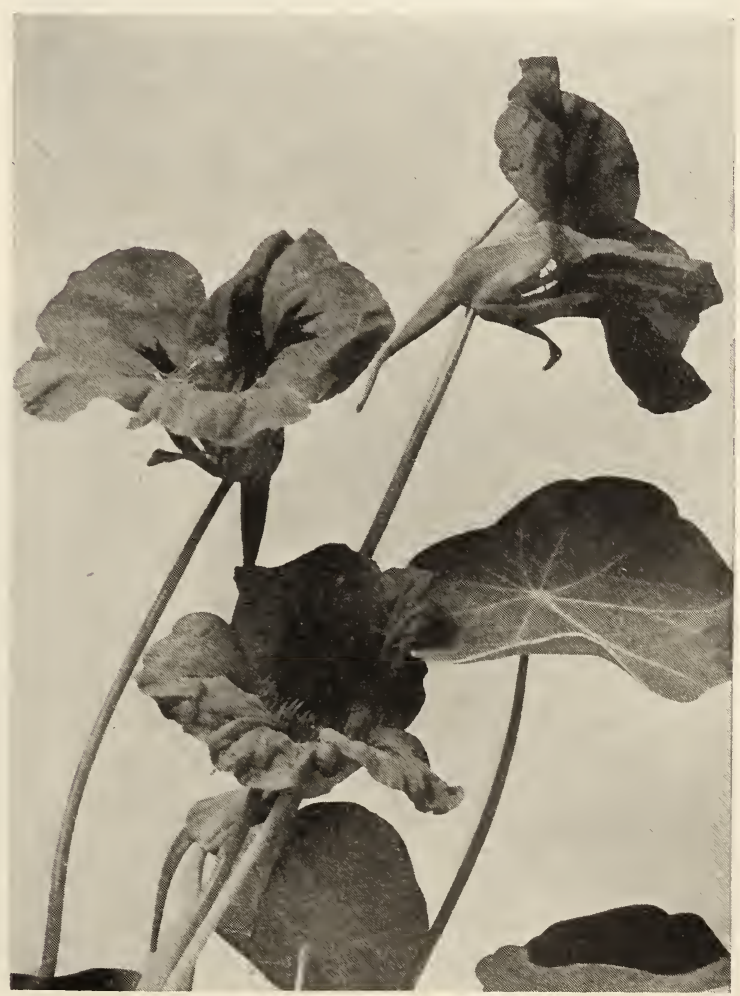

Tall Nasturtium 


\section{Pansies}

Truly speaking, a perennial, but an annual in California. To obtain the best results the seed should be sown in August, September, or early part of October. Prepare a bed in the open ground in the following manner: Dig up the ground and level off the surface. Take some good garden soil and run it the surface. Take some good garden a sieve, mix this with some good rotted manure and sand, which has also been screened, using about two parts of soil to one of manure and on it down seed broad-cast, coverig it with about an eighth of an broad-cast, coverig it with about an eighth of an
inch of the same soil, and again press the surface down with a board. Take a piece of burlap the size of the bed and stretch it out over the ground. Place some pieces of wood around the edge to keep the burlap from blowing away, and keep it well watered, burlap from blowing away, and a sine spray. As soon as the seed has using a fine spray. As soon as the seed has wooden framework the same size as the bed. Support this at each end by two small posts and a cross piece, placing this frame about one foot from the ground. After about a week, remove this framework, ground. After about a week, remove this fring the hottest part of the day. In two or three weeks it can be discarded entirely. When the plants are large enough to handle, transplant to beds of rich, well prepared soil, and cover the surface with a layer of well rotten, sifted manure. Pansies wrefer a rather heavy soil with plenty of well rotted manure; this is very essential. Indeed, it is almost manure; this is very essential. the richer the soil the larger and more perfect will be the flowers. Later sowings may be made up to the beginning of February, but they will not do as well as those sown early in the fall and the blooming period will be much shorter.

Payne's Royal Exhibition. Without question the Coast. See Flower Seed Specialties, page 7 .

Bugnot's Superb Blotched. Extra large, rich colors, each petal having a broad, deep blotch, many of them beautifully lined or penciled. Pkt., 50c.

Cassier' Large Flowered Blotched. A splendid strain; flowers beautifully blotched, of richest shades. Pkt., 25c.

Masterpiece. "Frilled Pansy." A grand new class, each petal being conspicuously waved or curled, giving the flower a double or globular appearance. Rich colors, mostly of the dark, velvety shades. Pkt., 25c.

Steele's Mastodon. This well known strain is universally popular on account of its immense flowers in mixed colors. Pkt., $25 \mathrm{c}$; $1 / 8$ oz., $\$ 1.25$.

Giant Trimardeau. Large flowered, mixed. Pkt., 15c. English Show or Faced Pansy. Mixed. Pkt., $15 \mathrm{c}$.
GIANT PANSIES, SEPARATE COLORS The following varieties, per pkt., $15 \mathrm{c}$; $1 / 8$ oz., $65 \mathrm{c}$.

Giant Bridesmaid. White and shining rose, beautifully blotched.

Giant Bright Blue. Ultramarine blue.

Giant Dark Blue. Darkest blue.

Giant Golden Yellow, Five Spotted, a beautiful flower of Cassier type.

Glant Golden Queen. Pure yellow.

Giant King of the Blacks. Velvety black.

Giant Light Blue. Pale blue.

Giant Lord Beaconsfield. Violet, upper petals shading to white.

Giant Madame Perret. Beautiful wine shades on white ground.

Giant Peacock. Royal purple and peacock blue.

Giant Snowflake. Pure white.

Giant mixed.

PeTUnia. Perennial, 1 to $1 \frac{1 / 2}{2}$ feet. Charming plants for large beds and borders, succeeding well in a sunny situation and blooming for the greater part of the year. Sow the seed in February in seed pans or boxes of light soil, cover the seed very lightly or boxes of light soil, cover the seed very lighty large enough, transplant to the open ground.

Note.-Seed saved from the most carefully hybridized flowers, produce about 30 per cent double flowers, the balance being singles of unusually fine quality. The weaker seedlings should be carefully saved, as these invariably produce the double flowsared as the the ers. sorts, the mall, weak seeding the largest and finest flowers, while the large, strong seedlings usually turn out to be the most common
types.

Double Fringed. Large flowered, mixed. Pkt., 50c. Payne's Giant Double Paeony Flowered. See page 8. Payne's Single Giants of California Ruffled and Fringed. See Flower Seed Specialties, page 8 .

Triumph. See Flower Seed Specialties, page 8.

Giant, Romany Lass. See Specialties, page 8 .

Giant, Steel Blue. See Specialties, page 8.

Blue. New, deep violet blue. Pkt., 25c.

Balcony Petunias. A new strain, very free flowering, desirable for window boxes, rock work, banks, beds and borders. Flowers large and of good subbeds and
stance.

Balcony Crimson. Pkt., $25 \mathrm{c}$.

Balcony White. Pkt., $25 \mathrm{c}$

Balcony Rose. Pkt., 25c.

Balcony Blue. Pkt., 25c.

Balcony Mixed. Pkt., 25c.

Rosy Morn. A dwarf, compact variety with rosecolored flowers, especially desirable for bedding. Pkt., 15c.

Rose of Heaven. Very dwarf, rose pink, desirable for bedding. Pkt., $15 \mathrm{c}$.

Single. Choice mixed. Pkt., $10 \mathrm{c}$

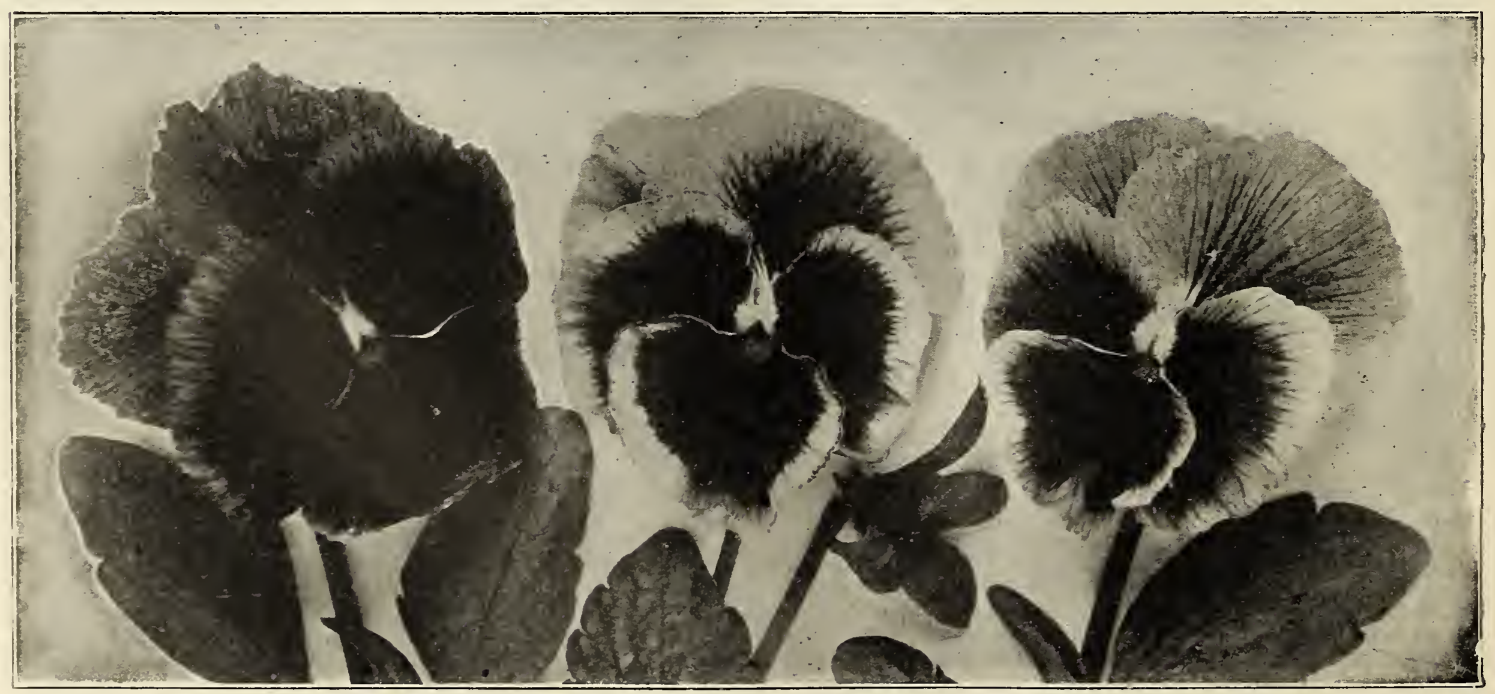

Payne's Royal Exhibition Pansies 


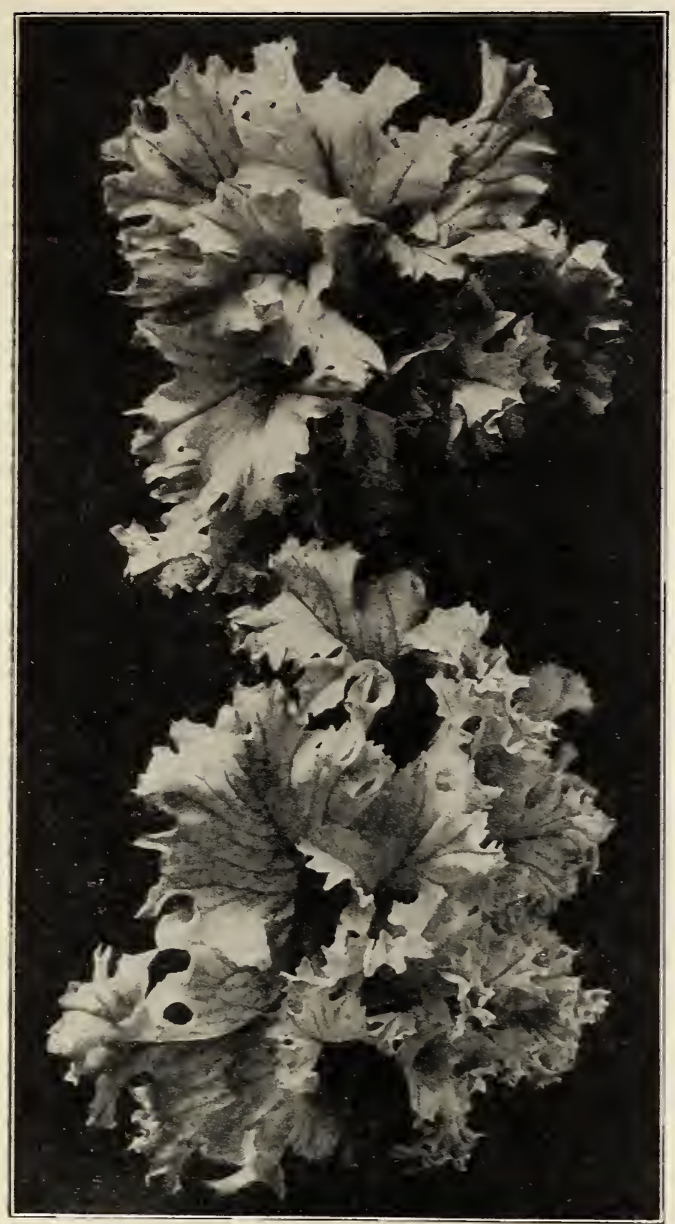

Double Fringed Petunia

PENTSTEMoN. Perennial, 2 to 3 feet. Free flowering plants for borders or beds. Colors in various shades of white, pink, red and purple; beautifully spotted or wow the seed in spring or early fall in seed boxes and when large enough, transplant.

Sensation. Large flowered, superb, mixed. Pkt., 15c.

PHLOX DRUMMONDI GRANDIFLORA Beautiful annuals, growing about 1 foot high with brilliant colored flowers, producing a dazzling display of color when planted in masses, in large beds or borders wow in seed boxes and when large enough transSow in seed boxes and

Primrose. Pkt., 10c; 1/8 oz., 35c.

Flesh Pink. Pkt., 10c; $1 / 8$ oz., $35 c$.

Scarlet. Pkt., 10c; 1/8 oz., 35c.

Crimson. Pkt., $10 \mathrm{c}$; $1 / 8$ oz., $35 \mathrm{c}$.

Lilac. Pkt., 10c; 1/8 oz., 35c.

Violet with white eye. Pkt., $10 \mathrm{c} ; 1 / 8$ oz., $35 \mathrm{c}$.

All Colors Mixed. Pkt., 10c; oz., 30c.

PHLOX DECUSSATA. "Perennial Phlox." This splendid, free flowering perennial is deserving of a place in every garden. The plants grow about 3 feet ligh and produce large heads of flowers of the most beautiful shades. Sow the seed in the fall in seed pan and afterwards transplant. All colors splendid mixed. Pkt., $15 \mathrm{c}$.

POLYANTHUS. (Primula elatior.) Perennial, 6 to inches; succeeding best in a partially shaded place and flowering during winter and early spring. Sow the seed in spring in seed boxes and transplant Large flowered choice mixed. Pkt., 15c.

Giant Munstead Strain. Very large flowers in beautiful light shades. Pkt., 25c.
POPPY, ANNUAL SORTS. Showy flowers for beds and borders, also very effective for sowing broadcast on waste pieces of ground. The best results will be obtained by sowing in fall or early winter.

Shirley. Single flowers of the most delicate crepelike texture and every conceivable shade of color from white, flesh-color, pink, rose, carmine, scarlet to deep crimson. Pkt., 10c; oz., 50c.

Shirley, Blue Shades. Grey-blue. Pkt., $15 \mathrm{c}$.

Shirley, American Leglon. New, brilliant orange scarlet. Pkt., 25c.

Shirley, Apricot Shades. Pkt., $15 \mathrm{c}$.

Barr's Double Queen. Select strain of double Shirley. Mixed colors. Pkt., 25c.

Tulip. Large single tulip-like flowers, color dazzlin scarlet. Height $1 \frac{1}{2}$ to 2 feet. Pkt., 10c; oz., $50 \mathrm{c}$

Admiral. Large single flowers, pure white with a broad band of brilliant scarlet around the upper part of the flower. Pkt., 10c.

Danebrog or Danish. Large single flower, brilliant scarlet with silvery white spot on each petal form ing a white cross. Height 3 feet. Pkt., $10 \mathrm{c}$

Umbrosum. Single flowers, rich vermilion with deep. black spot at base of petal. Height 2 feet. Pkt., 10c. Miss Sherwood. Large single flowers, satiny-whito, the upper half of petals chamois rose. Height 3 feet Pkt., 10c.

King Edward. Large single flowers; deep scarlet, shaded crimson, with large black blotch on lower half of each petal. Height 3 to 4 feet. Pkt. 10c.

Carnation Flowered. Large double fringed flowers, mixed colors. Height 3 to $4 \mathrm{ft}$. Pkt., 10c; oz., $40 \mathrm{c}$. White, Rose and Scarlet. Each, per pkt., $10 \mathrm{c}$

Paeony Flowered. Large double globular flowers, mixed colors. Height 3 to 4 feet. Pkt., $10 \mathrm{c}$.

Ranunculas Flowered. Double flowers about 2 inchen in diameter and of every imaginable shade of color. Height 2 feet. Pkt.. 10c; oz., 50c.

Ryburgh Hybrids. See page 8 .

New Poppy, Eldorado. See page 8.

POPPY, FLANDERS. See page 8.

POPPY, ICELAND. (Papaver nudicaule.) A perennial, blooming the first season from seed. Pretty, grayish fern-like follage, formed in tufts, from which rise numerous slender stems about 1 foot high, bearing single bright colored flowers. Sow the seed in seed boxes and transplant. Tew Giant Hybrids mixed. Plit., $15 \mathrm{c}$.

POPPY, ORIENTAL. (Papaver orientale.) A perennial producing many thick, leafy stems. 3 to 4 feet high, with large, deep crimson flowers, having a high, with large, deep crimson flowers, having a the seed in spring or early in the fall in seed boxes: when large enough, pot up into small pots and later transrlant to the open ground. Pkt., 15c.

Oriental Hybrids. Splendid hybrids of the Oriental Poppy, producing immense flowers, 6 inches or more in diameter and of many beautiful shades of pink, in diameter and of many beautiful shades of pink salmon, orange, scarlet, etc. Treat the
same as the preceding variety. Pkt., $15 \mathrm{c}$.

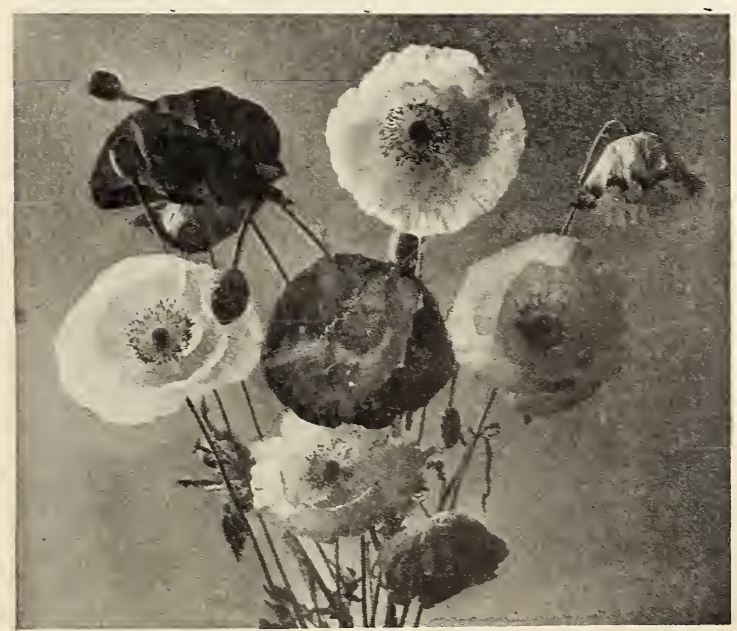

Shirley Poppies 
PORTULACA. A low spreading annual about 6 inche: high, flowering in a short time from seed and blooming through the entire summer season. Very effective for massing in beds, producing a perfect carpet of brilliant colors. Sow the seed in spring after the weather has become warm and settled.

Single, White, Yellow, Pink, Crimson or Mixed. Each, per pkt., 10c; 1/4 oz., $50 \mathrm{c}$.

Double, fine mixed. Pkt., $15 \mathrm{c}$.

PRIMULA SINENSIS FIMBRIATA. "Chinese Primrose." Beautiful greenhouse plants, blooming in winter and spring. Sow the seed in August or September in pots or seed pans of rich loam mixed with sand, cover the seed lightly and keep in a grenhouse; when large enough, pot into small pots and later to larger pots as required. The seed offered here is of the finest strains, imported direct from one of the best European growers.

Bright Rose. Large. Pkt., $25 \mathrm{c}$.

Detiance. Rich red, with dark eye. Pkt., $25 \mathrm{c}$

Holborn Blue. A unique shade. Pkt., 25c.

Snow Queen. Pure white, extra fine. Pkt., 25c.

Choice mixed. Pkt., 25c.

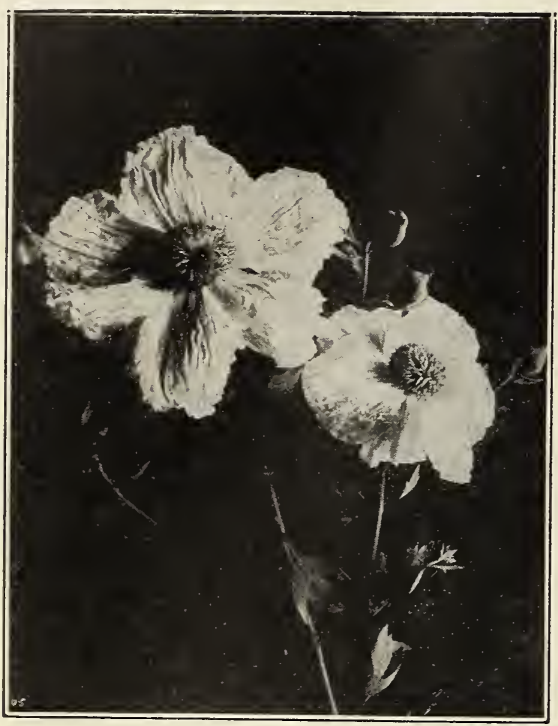

Romneya Coulteri

PRIMULA SINENSIS STELLATA. "Star Primroses." A new strain of Primula, though the flowers are slightly smaller than P. sinensis fimbriata the plants are of more robust growth and produce flowers much more freely.

Choice mixed. Pkt., 25c.

PRIMULA KEIVENSIS. Yellow, very desirable for outdoor culture. Pkt., 25c.

PRIMULA OBCONICA GIGANTEA. A charming little plant for pot culture. Perennial but blooming in a few months from seed; height 6 to 8 inches. A profuse bloomer, bearing heads of 10 to 15 flowers on long stems. Sow the seed in August or September in pots or seed pans of light, rich loam and keep in a frame or greenhouse, pot up when ready. Mixed colors. Pkt.. 25c.

PRIMUla maLACoInEs. See page 8.

PYRETHRUM. "Golden Feather." Pretty foliage plants with deeply cut leaves, useful for edgings; perennial, 6 to 9 inches. The plants should be kept trimmed and all flowers cut off as they appear. Sow the seed in boxes, covering very lightly, and when large enough, transplant.

aureum. Golden yellow foliage. Pkt., 10c.

PYREThRUM RoseUM. Perennial 1 to 2 feet. Fernlike foliage and large marguerite-like flowers, very desirable for cutting.

Roseum. Rose pink. Pkt., $15 \mathrm{c}$

Roseum, New Hybrids. Mixed colors. Pkt., 15c.

RHODANTHE. A graceful little "Everlasting Flower," annual, 1 foot high. Treat the same as Acroclinium. Pink, rose, white, crimson, etc. mixed. Pkt. 10c.
RICINUS. "Ornamental Castor Bean." Rapid growing plants with immense, rich colored leaves, producing a sub-tropical effect planted on lawns or in clumps. Height 6 to 10 feet. Sow in spring when the weather has become warm and settled.

Cambodgensis. Main stem and leaf stalks rich, shining ebony; leaves large, maroon with red veins. Pkt., 10c.

Gibwoni. Dark purplish red foliage and stems. Pkt., 10c.

Zanzibariensia. Very large, dark leaves, with reddish stems. Plants grow to immense size. Pkt., 10c.

ROMNEYA COULTERI. "Matilija Poppy." A native of California; perennial, 6 to 10 feet high and of shrubby growth. The queen of California flowers; truly a majestic plant. The plant throws up ers; truly a majestic plant. The plant throws up fumerous woody stems with handsome gray-green blossoms are often 6 to 7 inches in diameter, of 8 blossoms are often 6 to 7 inches in diameter, of a yellow centers. The seed is hard to germinate; some claim to have had success by soaking the seed in a week solution of lye. Pkt., 15c.

SALPIGLOSSIS GRANDIFLORA. Annual, 1 1/2 feet. Free flowering plants for beds and borders; succeeding best in a sunny situation and blooming all summer. The plants are large, funnel-shaped and produced in great profusion; colors yellow, pink, rose, crimson, brown, steel blue, purplish violet, etc.; beautifully velned and penciled. Sow the seed early in spring in seed boxes and transplant when large enough. Mixed colors. Pkt., 10c.

SALVIA SPLENDENS. "Scarlet Sage." For producing a dazzling mass of color all through the summer months there is probably no other flower that can equal the "Scarlet Sage." It is a perennial, but blooms in a short time from seed. Much used for bedding and succeeding best in a sunny situation. Sow the seed in February or March in seed boxes and when large enough, transplant.

plendens. Long spikes of vivid scarlet flowers; height 2 to 3 feet. Pkt., 10c.

"Bonfire." Forms compact, bushy plants about 2 feet high by 2 feet in diameter. The flower opikes stand erect, often bear 20 to 30 blossoms and 200 of these spikes on a plant is not unusual; color vivid scarlet. Pkt., 15c.

SALVIA PATENS. "Blue Sage." Perennial, 2 feet, flowering the first season from seed, succeeding best in a partially shaded situation. Flowers the most perfect shade of bright blue. Sow the seed the same as the preceding varieties. Pkt., $15 \mathrm{c}$.

SALVIA FARINACEA. Perennial, 2 to $3 \mathrm{feet,} \mathrm{flower-}$ ing the first season from seed and succeeding best in a sunny situation. Flowers light lavender. Sow the seed same as the preceding varieties. Pkt.,15c.

SCABIOSA. "Sweet Scabious." "Mourning Bride." Annual, 2 to 3 feet, flowering in summer and eariy fall. Flowers on long stems, produced in great profusion and especially valuable for cutting, lasting a long time in water. Sow the seed from February to April in seed boxes and transplant. The strain I April in seed boxes and transplant. Thent on the oldam offering here is a great improvement on the oldinches in diameter, double and of the most exquisite Inches

Large-flowered donble. Azure Fairy, Crimson, Flesh Pink. Red, Rose, or Mixed. Each, per pkt., $10 \mathrm{c}$.

Peach Blossom. See page 9.

SCABIOSA CAUCASICA. See page 8 .

SCABIOSA COLUMRARIA. See page 8.

SCHIZANTHUS. Annual, $1 \frac{1}{2}$ to 2 feet, producing pretty, butterfly-like flowers in great profusion, exquisitely spotted and marked, resembling some orchids in coloring. Large flowered mixed. Pkt. $10 \mathrm{c}$

SCHIZANTHUS WISETONENSIS. See page 8

SHASTA DAISY. One of the most popular of Mr. Burbank's productions. Perennial, about 2 feet high, flowering for the greater part of the year, but at its best in spring and early summer. Desirable for beds or borders and especially valuable for cutting purposes, flowers lasting a long time in water. Sow in spring or early fall in seed boxes, covering the seed very lightly; when large enough transplant.

Alaska. Flowers often 4 inches across, purest glistening white, with yellow centers; broad overglistening white, with yellow centers

SILENE PENDULA COMPACTA. Annual, forms compact little plants about 6 inches high, flowers rosecolored; useful for edgings, etc. Pkt., 10c.

SMILAX. Perennial climbing vine, 6 to 8 feet, thriving best in a partially shadea place. Largely grown for decorating purposes. Soak the seed in hot water for a few hours before sowing. Pkt., 10c. 
STATICE LATIFolia. "Sea Lavender." Perennial, $11 / 2$ feet, producing panicles of small lavender blue flowers, which can be cut and dried and used for bouquets. Sow the seed late in spring or early in the fall, in seed boxes, and transplant. Pkt., 10c; oz., $\$ 1.50$.

macrophylla. Large, deep blue. Pkt., 10c; oz., 60c. caspla. New, pale blue, extra fine. Pkt., 10c; oz. $\$ 2.00$.

Sinuata. Annual, Blue. Pkt., 10c.; oz., 60c.

Bonduelli. Annual, yellow. Pkt., 10c; oz, 60c.

Perezi. Perennial. Deep blue. Pkt., 10c; oz., $\$ 2.00$ suworowi. Annual, pink flowers. Pkt., $15 \mathrm{c}$.

STEVIA SERRATA. Perennial, 2 feet, flowering the first season from seed, furnishing quantities of uable for cutting. Pkt, 10c.

STOCKS. "Gilliflower." A favorite annual, succeeding best in California during the winter season. Largely grown for cut flowers, lasting a long time in water. Very effective for planting in beds or borders. To obtain the best results the seed should be sown in August, September, or early part of October, in seed boxes of rather light soll, and afterwards to the open ground. In transplanting stocks care should be taken to save the small or weak growing plants, as these generally produce double flowers, while the strong, robust growing tained from one of the best specialists and can be tained from one of the best specialists and can be flowers.

Nice Giant. See Flower Seed Specialties, page 9.

Bismarck. See Flower Seed Specialties, page 9.

SUNFLOWER. SE HELIANTHUS.

SWEET WILLIAM. Perennial, 1 foot. An old-fashloned flower for beds or borders, producing a great display of showy and varied colors. Sow the

Auricula-flowered. Beautifully ringed and marAuricula-fowered, Beautifully
gined, mixed colors. Pkt., $10 \mathrm{c}$.

Newport Pink. Bright pink. Pkt., $15 \mathrm{c}$.

Sinele, all colors mixed. Pkt.. 10c.

Double, all colors mixed. Pkt., 15c.

Anuual sweet IIlliam. A new strain flowering in a short time from seed. Mixed colors. Pkt., 10c.

TACSONIA MANicata. "Scarlet Passion Vine." A magnificent perennial climber, producing an abundance of large scarlet blossoms. Sow the seed in pots or seed pans and transplant. Pkt.. 25c.

Mollissima. "Pink Passion Vine." Perennial climber large rose-pink flowers. Sow seed same as the preceding species. Pkt., 15c.

TAGETES Signata PUMiLA. A miniature Marigold, forming compact little plants 6 to 8 incnes high, and completely covered with flowers, which are bright yellow with brown stripe down the center of each petal. Annual fowering during the summer season, very striking for edgings. Sow the seed in spring in boxes and transplant. Pkt., $10 \mathrm{c}$.

THA LICTR UM DIPTER OCA RPUM. Perennial, 2 to 3 feet. Beautiful foliage resembling maidenhair fern: tall graceful stems with small panicles of lilac blossoms. Very desirable for cutting. Pkt., $25 \mathrm{c}$.

THUNBERGIA ALATA. A anual climbing vine 5 to 6 feet, useful for low fences; also for hanging baskets. Sow the seed in spring. Flowers white, yellow, orange and hufr. with dark centers, mixed. Pkt., $10 \mathrm{c}$.

TITHONIA SPECIOSA. See page 9.

TRUPA EOLUM CANARIENSE, "Canary Bird Flower." Annual, climbing vine 8 to 10 feet. It does best in California in a rather moist, partially shaded situation. Pretty pale green, deeply cut follage and canary yellow, fringed flowered. Sow early in spring. Pkt., 10c.

VERBENA. Perennial of reclining habit, height 9 to 12 inches. The plants bloom the first season erom seed and are unsurpassed for bedding where a display of color is desired. After they are established play of color is desired. After they are established they grow with scarcely any attention and a small the seed in winter or early spring in seed boxes and when large enough, transplant.

Mammoth, White, pink. blne, purple or Scarlet Defiance, each, per pkt., $10 \mathrm{c}$; $1 / 4$ oz., $60 \mathrm{c}$

Mammoth, all colors mixed. Pkt., $10 \mathrm{c} ; 1 / 4$ oz., $50 \mathrm{c}$

Lucifer. New brilliant scarlet with no eye; compact growth. Pkt. 15c.

VERBENA ERINOIDES. "Moss Verbena." Perennial of trailing habit with finely cut foliage and great quanities of purple flowers; especially useful for planting in parkings and requires very little water. Pkt. $15 \mathrm{c}$.

VERBENA HYBRIDA GIGANTEA. See page 9.

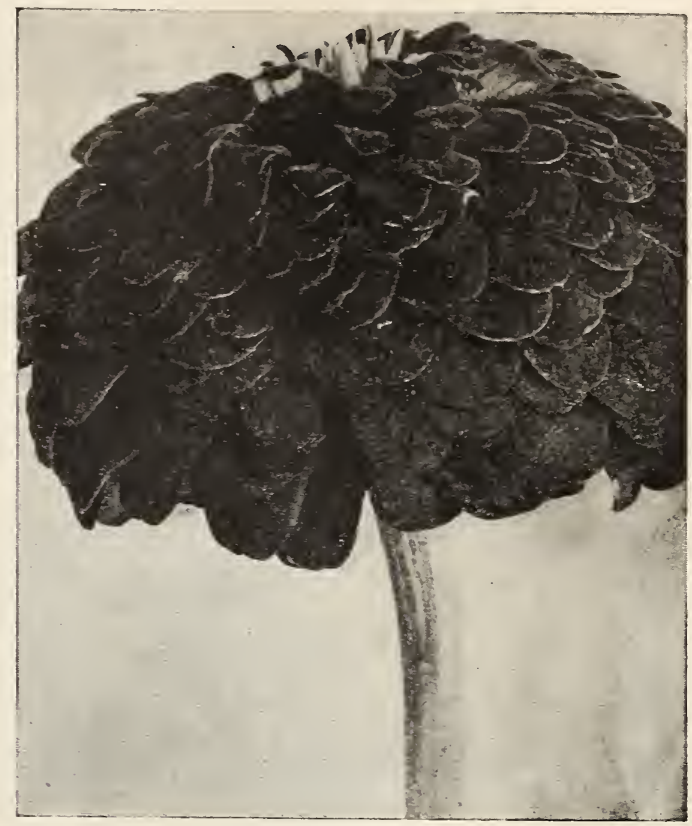

Giant Zinnia

VISCARIA. Free flowering annual growing about 3 foot high. Very effective for planting in masses making a great display for many months. The flowers come in various shades of pink, rose, carmine, blue and white.

cardinalis. Bright carmine. Pkt., 10c.

oculata coerulea. Blue. Pkt., $10 \mathrm{c}$.

oculata mixed. Pkt., $10 \mathrm{c}$.

oculata, dwarf, Loyalty. Blue. Pkt., $15 \mathrm{c}$.

VIOLA ODORATA. "Sweet Violet." A favorite fra. grant flower, perennial, 6 inches. Succeeding best in a rather shady situation. Sow the seed in winter or early spring, in seed boxes of good loam mixed with some leaf-mould, covering the seed lightly, or they may be sown in a well-prepared bed in a shady situation. Violet seed is slow to germinate.

odorata. The old-fashioned Sweet Violet. Pkt., 10C.

VIOLA CORN UTA. "Tufted Pansies." Though the flowers are not as large as the regular pansies, they bloom so freely that many people consider them superior where a mass of color is desired. The plants bloom for a long period and the colors are particularly clear and distinct. The flowers are light and graceful, and not so stiff as those of the regular pansy. Sow the seed from August to January in pansy. Sow the seed from August to Janua. Admiration. Deep purple. Pkt., $15 \mathrm{c} ; 1 / 8-0 z ., 75 \mathrm{c}$. Papilio. See Flower Seed Specialties, page 9 Lutea splendens. Clear yellow. Pkt., $15 \mathrm{c} ; \%$ oz., $75 \mathrm{c}$. Mixed colors. Pkt., $15 \mathrm{c}$; $1 / 8$ oz., $75 \mathrm{c}$.

VIRGINIAN STOCK. A charming little annual growing about 6 inches high, covering the ground with a perfect mass of flowers. Desirable for beds and borders. Crimson King, Deep crimson. Pkt., 10c; oz., 50c. Fairy Queen. Bright red. Pkt., 10c; oz., 50 c.

Yellow. Pkt., $10 \mathrm{c}$; oz., $50 \mathrm{c}$

Mixed colors. Pkt., $10 \mathrm{c}$; $0 \mathrm{z} ., 35 \mathrm{c}$

WALLFLOWER. An old-fashioned fragrant flower biennial, 1 to 1 1 feet. Sow the seed in spring and transplant. plants will flower the following winter Blood red. Dwarf compact plants. Pkt., 10c. Single mixed. Pkt., 10c.

Double mixed. Pkt., $15 \mathrm{c}$.

Annual. Single mixed. Pkt., $10 \mathrm{c}$

Winter Flowering. See page 9

ZINNIA ELEGANS. A favorite summer flowering annual for beds and borders, thriving best in a sunny situation. The seed can be sown early in spring in seed boxes and transplanted, or later on in the open grnund.

Tall Double Mixed. Height, 2 to 3 feet. Pkt., 10c; 1/4 oz., $30 \mathrm{c}$.

pumila. See page 10 .

Lilliput. Dwarf, very small, perfectly double flowers; mixed colors. Pkt., 10c; $1 / 4$ oz., $50 \mathrm{c}$.

Payne' Fiant Double. See specialties page 10. New Dahlia Flowered Zinnia. See page 10. 


\section{Payne's Sweet Peas}

Can be sown at any time from September to March; early planting will produce the best results. They require an open situation, good rich soil and plenty of water. Sow in drills covering the seed about 2 " deep or a trifle more in light soils. When about a foot high draw the earth up to the stems with a hoe. They should have brush, sticks or wire netting to climb over. By keeping the flowers gathered and any dead flowers cut off, the plants will bloom for a long period

\section{New Winter Flowering or Long Season Spencer Sweet Peas.}

A new race of Sweet Peas, having the large waved flowers of the Spencer type, but flowering fully two months earlier, they also continue in flower for a much longer period. For Christmas flowering sow in September; later sowing may be made up until March.

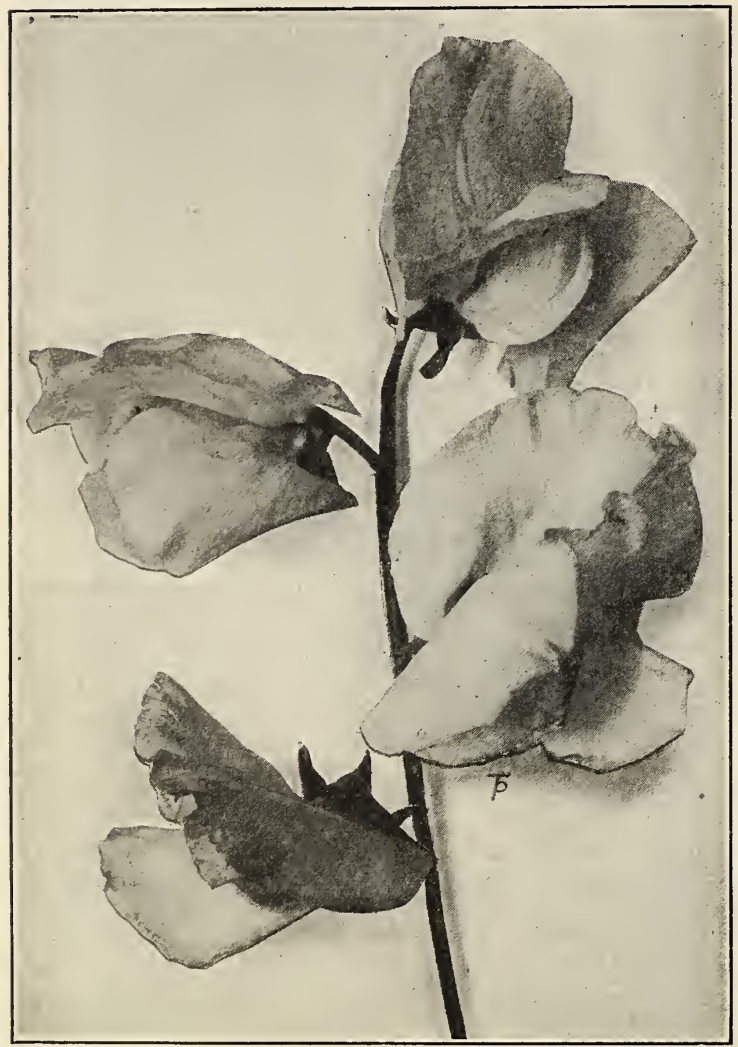

Winter Flowering Sweet Pea "Fair Maid"

All White. Pure white, large flowers. Pkt., 25c oz., $\$ 1.00$.

Amethyst. Royal purple. Pkt., 25c; oz., \$1.00.

Aviator. Dazzling crimson scarlet. Pkt., 25c; oz., $\$ 1.00$.

Bluebird. Violet blue. Pkt, 25c; oz., $\$ 1.00$.

Columbia. Pink and white, large. Pkt., 25c; oz., $\$ 1.00$.

Fair Maid. Blush pink and salmon. Pkt., 25c; oz., $\$ 1.00$.

Glitters. Glowing scarlet cerise. Pkt., 25̃c; oz., $\$ 1.00$.
Grenadier. Dazzling scarlet. Pkt., 25c; oz., $\$ 1.00$.

Harmony. Clear lavender. Pkt., 25c; oz., $\$ 1.00$.

Hereules. Rosy pink, very large. Pkt., 25c; oz., $\$ 1.00$. Miss Louise Gude. Brilliant pink. Pkt., 25c; oz. $\$ 1.00$.

Mrs. Kerr. Salmon buff. Pkt., 25c; oz., $\$ 1.00$.

Rose Charm. Bright rose, large. Pkt., 25c; oz., $\$ 1.00$.

Rose Dore. Rose pink, suffused orange. Pkt., 25c; oz., $\$ 1.00$.

Sweet Lavender. Pure lavender. Pkt., 25c; oz., $\$ 1.00$. Zvolanek's Rose. Rose pink, F'kt. 25c oz. $\$ 1.00$

Early Choice mixed. Pkt., 25c; oz., 75c.

SPECIAL OFFER.-Five varieties Payne's New Winter Flowering Sweet Peas in separate packets for $\$ 1.00$

\section{Payne's Spencer Sweet Peas}

The Spencer Sweet Peas have large, round, open flowers of extraordinary size, often 2 inches across, with wavy standard and wide-spreading wings, large number of the flowers coming four on a stem. lis the old large flowered yereat improvedint in discarded many of the older varieties for newer and better ones. The following list contains the very best varieties of each color to date.

Barbara. Salmon pink. Pkt., 10c; oz., 40c.

Crimson King. Rich deep crimson. Pkt., 10c; oz., $40 \mathrm{c}$.

Edna May Improved. Pure white. Pkt., 10c; oz., 40c. Elfrida Pearson. Shell pink. Pkt., 10c; oz., 40c.

Fiery Cross. Brilliant orange cerise. Pkt., 10c; oz.

Hawlmark Pink. Bright rose pink, shaded salmon. Pkt., 10c; oz., 40c

Hercules. Rosy pink, immense flower. Pkt., 10c; oz., $40 c$

IIluminator. Brilliant orange scarlet. Pkt., 10c; oz. 40c.

Margaret Atlee. Rich pink suffused with salmon. Pkt., 10c; oz., $40 \mathrm{c}$

Matchless. Cream. Pkt., 10c; oz., 40c.

Mrs. Tom Jones. Bright delphinium blue. Pkt., 10c; oz., $40 \mathrm{c}$.

Pleture. Delicate pink on cream ground. Pkt., 10c; oz., $40 \mathrm{c}$.

R. F. Felton. The best lavender. Pkt., 10c; oz., 40c. Rosabelle. Light rose pink, very large. Pkt., 10c; oz., 40c.

Royal Purple. Deep rich purple. Pkt., 10c; oz., 40c. Royal scott. Glowing orange scarlet. Pkt., 10c; oz., $40 \mathrm{c}$

Tangerine Improved. Glowing orange. Pkt., 10c oz., $40 \mathrm{c}$.

The Cardinal. Intense poppy scarlet. Pkt., 10c; oz., $40 \mathrm{c}$.

Warrior. Deep rich maroon. Pkt., 10c; oz., 40c.

Wedgewood. Light blue, extra fine. Pkt., 10c; oz., $40 \mathrm{c}$.

Spencer Mixed. Pkt., 10c; oz., 30c; 1/4-1b., $\$ 1.00$.

SPECIAL OFFER. Six varieties Payne's Spencer Sweet Peas in separate packets for $50 \mathrm{c}$.

We have in stock at all times a greater assortment of flower seeds than will be found in any seed store west of Chicago. An enviable reputation gained through 25 years of consistent effort to procure the best that can be grown is your assurance of fresh, reliable seeds. 


\section{California Wild Flower Seeds}

The extent and beauty of California's native flowers is just becoming established in the mind of the average home gardener. For many years they were thought of only as "wild flowers," not suitable for planting in anyone's garden, and it is only upon the noticeable lack of them that the thought occurs they were beautiful after all, and well worthy of a place under our particular sun. Their charm lies not only in their exquisite colors and delicate texture but in the romance and personality they give to a garden-they mean something beyond "some flowers."

Abronia umbellata. "Sand Verbena." Perennial, low triling bena. Thrives best in sandy soil. Pkt., 10c; oz., $70 \mathrm{c}$.

Abronia villosa. "Desert Sand Verbena." Annual of low trailing habit. Flowers lavender pink. Found abundantly on the sands at Palm Springs and other places on the desert. Pkt., 10c; oz., 70c.

Agoseris major. "Morning Radiance" Annual, 8 to 12 inches high. Flowers large, on single stems, deep golden yellow. The blossoms open at daylight but gold present a brilliant display. Pkt., 15c; 1/4 oz., $\$ 1.00$.

Amsinkia douglasiana. "Woolly Breeches." Annual, 1 to 3 feet high. Small orange colored flowers produced in great quantities. Often seen in great masses producing a vivid patch of color on the hillsides. Pkt. $15 \mathrm{c}$; oz., $\$ 1.00$.

Antirrhinum coulterianum. "White Snapdragon." Annual, 3 to 5 feet high. Small white flowers in sikes often 2 feet long. Pkt., 15c.

Antirrhinum glandulosum. "Pink Snapdragon." Perennial, 3 to 5 feet high, branching from a stout woody base. Flowers rose pink in long spikes. Pkt., $15 \mathrm{c}$.

Aquilegia truncata. "Columbine." Perennial, 2 to 3 feet high. Flowers scarlet tipped with yellow. Succeeds best in a moist, shady place. Pkt., 15c; $1 / 8$ oz., $75 \mathrm{c}$.

Argemone platyceras hisplda. "Prickly Poppy." Annual, $11 \%$ to 3 feet high. Flowers white with yellow center. Pkt., $10 \mathrm{c}$.

Baeria gracilis. "Sunshine." Annual, 4 to 8 inches high. Golden yellow, star-shaped flowers. Pkt., 10c: OZ.s $\$ 1.00$.

Calandrinia mensiesii. "Red Maids." Annual, of spreading habit; flowers rose-red, opening in the sunlight. Pkt., 15c; $1 / 4$ oz., 50c

Castilleja californica. "Indian Paint Brush." Perennial, 1 to 2 feet high. Flower bracts deep scarlet. Pkt., 15c.

Cirsium coulteri. "Scarlet Thistle," Biennial, 5 to 8 feet high. A showy plant with whitish green foliage and large crimson-scarlet flowers. Pkt., 15c; oz. $\$ 2.00$.

Clarkia concinna, "Red Bibbons." Annual, 8 inches to 2 feet high. Flowers rose-pink with crimson sepals Prefers a shady spot. Pkt., 10c; oz., \$1.00.

Clarkia elegans. "Clarkia" Annual, 3 to 6 feet. A slender growing plant; flowers purple with white and slender growing plant; flowers purple with white and oz., $40 \mathrm{c} ; 1 \mathrm{~b} ., \$ 5.00$.

Collinsia bicolor. "Innocence." Annual, 1 to 2 feet hich shady situation. Pkt., 10c; oz., 35c; lb., \$4.00.

Collinsia grandiflora. "Blue Collinsia." Annual 6 to 10 inches high. Flowers deep violet blue. Prefers a shady situation. Pkt., 10c; oz., $50 \mathrm{c}$.

Coreopsis donglasil. "Yellow Daisy." Annual, 6 to 12 inches. A graceful little plant with bright yellow daisy-like flowers. Pkt., 15c; oz., \$1.50.

Coreopsis stllimani. "Yellow Mountain Daisy." Annual, 9 to 12 inches high. Bright jellow, daisy-like flowers. Pkt., 15c; oz., \$1.50.

Coreopsis maritima. "Sea Dahlia." Perennial, 2 to $2 \frac{1}{2}$ feet high. Flowers large, light canary yellow. Pkt., $15 \mathrm{c}$.

Delphinium cardinale. "Searlet Larkspur." Perennial, 3 to 6 feet. Produces long spikes of bright scarlet flowers. Pkt. 10c; 1/4 0z., 75c.,

Delphinium parryi. "Blue Larkspur." Perennial, 1

to 3 feet high. Flowers large, rich blue Pkt $15 \mathrm{c}$ $1 / 8$ oz., $75 \mathrm{c}$.

Dendromecon rigidum. "Tree Poppy." Perennial shrub, 4 to 8 feet high. Bright yellow flowers, 3 inches or more in diameter. Seed is hard to germinate. Pkt., or more in diam 15 oz. $\$ 1.00$.
Dicentra chrysantha. "Golden Ear Drops." Perennial, 3 to 5 feet high. Finely cut glaucous foliage and rich yellow flowers. Pkt., 15c; 1/4 oz., \$1.00.

Dodecatheon clevelandi. "Shooting Star." Perennial, 1 to $11 / 4$ feet high. Flowers in shape like a cyclamen, delicate lilac and white. Pkt., 15c; 1/8 oz., $75 \mathrm{c}$.

Emmenanthe penduliflora. "Whispering Bells." Annual, 1 to 2 feet high. Produces large quantities of bell-shaped. pendulous flowers, cream-colored or yellow. Pkt., 10c; oz., \$2.00.

Encelia californica. "Bush Sunflower." Perennial shrub, 2 to 6 feet high; found on dry banks, blooming in the spring and early summer. Flowers bright yellow with dark centers. Pkt., 10c.

Erysimum asperum. "Wild Wallfower." ..Perennial, 2 to 4 feet high. Long spikes of large, orange-colored, fragrant flowers. Pkt., 15c., oz., \$1.50.

Eschscholtzia californica. "California Poppy." Annual, 1 to $1 \frac{1}{2}$ feet. The most noted of California Wild Flowers. Orange-yellow, with a beautiful glossy sheen. Pkt., 10c; oz.. 35c; 1b., \$3.00.

Floerkia douglasil. "Meadow Foam." Annual, of low spreading habit; flowers cream-colored. Prefers a moist location. Pkt., 10c; oz., 50c.

Frasera parryi. Perennial, $1 \frac{11 / 2}{\text { to } 21 / 2}$ feet high. Pro duces loose clusters of star-shaped flowers, brown yellow and green, mottled and blended. Pkt., $15 \mathrm{c}$.

Gilia abrotanifolia. Annual, $1 \frac{11}{2}$ to $2 \frac{1}{2}$ feet $\mathrm{high}$. Large heads of very pale blue flowers. Pkt., 10c; oz., $40 \mathrm{c}$; 1b., $\$ 5.00$.

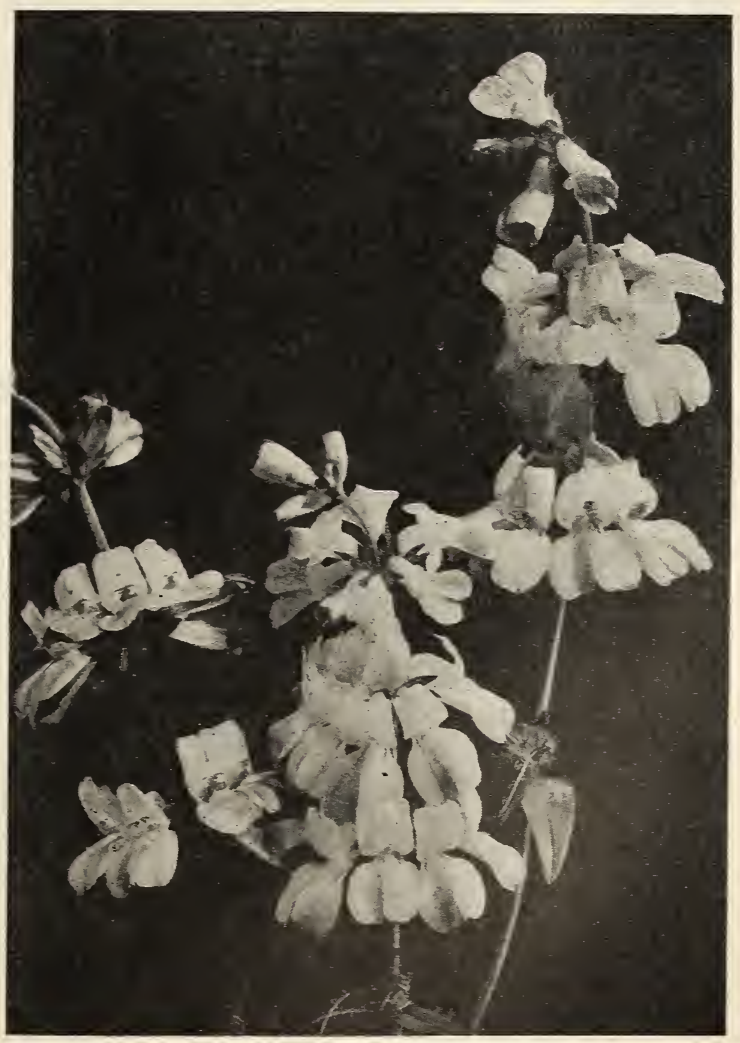

Collinsia bicolor. "Innocence" 


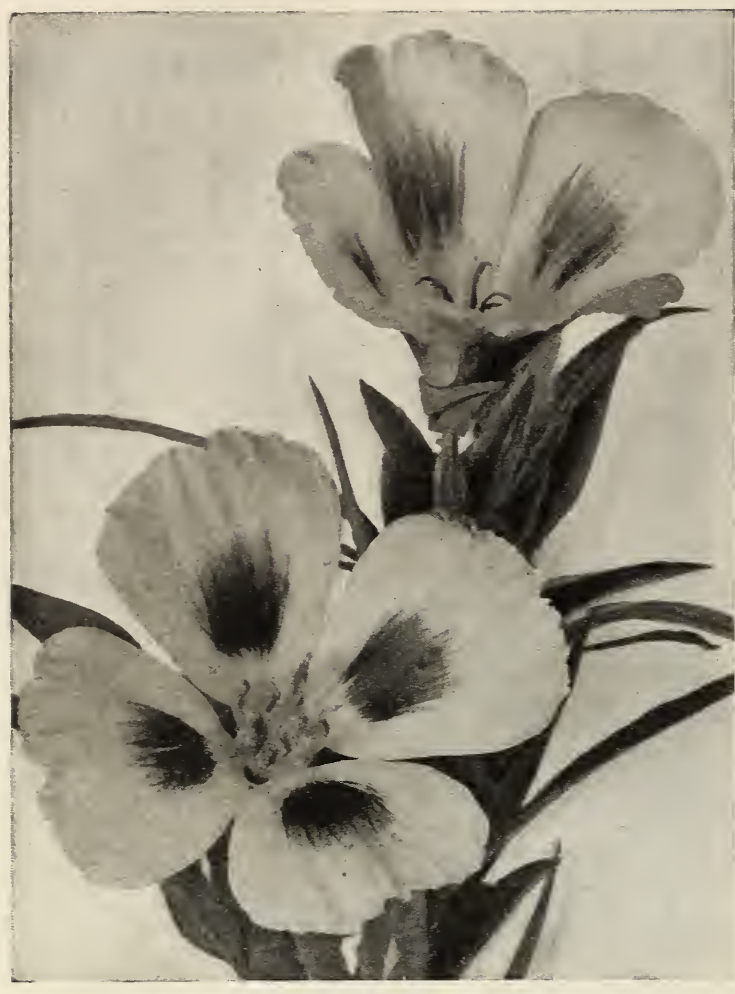

Godetia grandilloro- "Farewell to Spring"

Gilla achillaefolla. "Blue Gilla." Annual, 1 to $1 \frac{1}{2}$ feet high. Small violet-blue flowers in dense heads on graceful, slender stems. Pkt., 10c; oz., 35c; lb. $\$ 4.00$.

Cilla aurea. "Tellow Gilia." Annual, 4 to 10 inches high. A pretty little plant with thread-like stems and yellow flowers. Found in sandy washes Pkt., 15c.

Gilia capitata. "Large Blue Gilia." Annual, 1 1/ to $21 / 2$ feet high. A slender, somewhat branched plant, with finely cut follage and light blue flowers. Rlooms later than Gilia achillaefolia. Pkt., 10c; oz., 40c; lb., $\$ 5.00$.

Gilla callfornica. "Prickly Phlox." Shrub, 2 to 4 feet high. Prickly needle-like leaves. Fragrant phloxlike flowers of a delicate rose pink color. Pkt.. $25 \mathrm{c}$.
Gilia dianthoides, "Fringed Gilia," or "Ground Pink." Annual, 2 to 6 inches high. An exquisite little plant with minute leaves and phlox-like flowers, rose colored or lilac with yellowish throat. Pkt., $15 \mathrm{c}$.

Gilia tricolor. "Birds' Eyes." Annual, 9 to 12 inches. Flowers pale lilac, yellow toward the center, with flve purple spots. Pkt., 10c; 0z., 40c; 1b., \$5.00.

Godetia amoena. "Farewell to Spring." Annual, 1 to 2 feet high. A slender growing plant, usually found on shady banks. Flowers lilac-crimson or red-pink, often with a dark center. Pkt., $10 \mathrm{c} ; 0 \mathrm{z} ., 60 \mathrm{c} ; 1 \mathrm{~b} ., \$ 7.00$.

Godetia bottae. "Farewell to Spring." Annual, 2 to 3 feet high. Flowers pale rose or lilac. Prefers a partially shady place. Pkt., 10c; oz., 70c; lb., \$8.00.

Godetia grandiflora. "Farewell to Spring." Annual, 1 to 2 feet high. Flowers large, delicate nink, marked with rich crimson. A beautiful flower. Pkt., 10c; oz. $60 \mathrm{c} ; 1 \mathrm{~b} ., \$ 7.00$.

Godetia viminea. "Farewell to Spring." Annual, 1 to 2 feet high. Upper half of petals lilac with darker blotch; lower half white often with lilac ring at base very attractive. Pkt., $10 \mathrm{c}$; oz., $80 \mathrm{c}$; $1 \mathrm{~b} ., \$ 9.00$.

Hellanthus annuus. "Sunflower." Annual, 5 to 8 teet high. Flowers yellow with dark brown centers. Pkt., 10c; oz., 60c.

Lasthenia glabrata. “Lasthenia" Annual, of spreading habit; golden yellow daisy-like flowers. Grows in moist places. Pkt., $15 \mathrm{c}$; oz., $\$ 1.50$.

Lathyrus laetiflorus. "Wild Pea." Perennial climber. Flowers in loose clusters, white or flesh-color veined with purple. Pkt., $10 \mathrm{c}$; oz., $60 \mathrm{c}$.

Lathyrus splendens. "Pride of Callfornia." A perennial climbing pea. Flowers large, deep, rich crimson. Pkt., 15c.

Layia elegans. "Tidy Tips." Annual, 1 to 2 feet. A yellow daisy, edged with white or cream color. Pkt. $10 \mathrm{c} .$, oz. $\$ 1.00$.

Layia glandulosa. "White Daisy." Annual, 9 to 15 inches high. Flowers, clear glistening white, with yellow centers. Grows in sandy soil. Pkt., 15c; oz. $\$ 2.00$.

Linanthus densiflorus. "Callfornia Phlox." Annual, 1 to 2 feet high. Flowers in crowded clusters; rink and purple with yellow throat. Pkt., 10c; oz., 60c; Ib., $\$ 7.00$.

Linnm lewisl. "Tlue Flax." Perennial, 1 to 2 feet high from a woody base. Flowers large sky blue. Pkt., $15 \mathrm{c}$.

Lupinus affinis "Blue Lnine" Annual 1 to 2 reet. Flowers blue and purple. Pkt., 10c; oz., 35c; lb., \$4.00.

Lupinus arboreus. "Yellow Tree Lupine." ..Shrubby perennial 4 to 10 feet high. Flowers rich sulphur yellow. Pkt., 15c; oz., $75 \mathrm{c}$.

Lopinus brittoni. "Britton's Bush Lupine." Shrubby perennial 4 to 5 feet high Flowers in long racemes, rich blue. Pkt., 25c; oz., \$1.50.

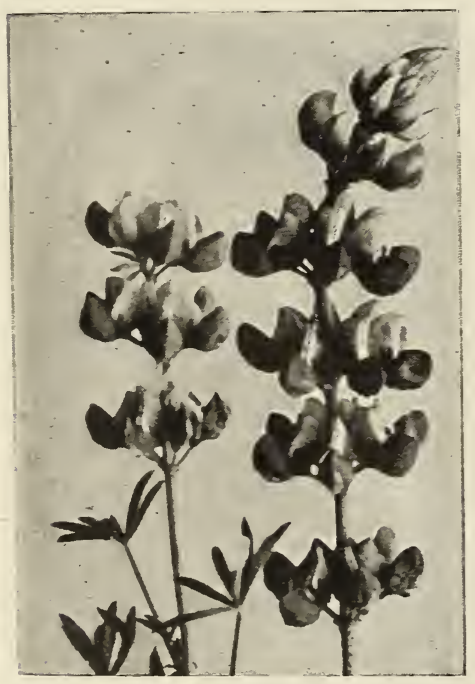

Lupinus nanus "Dwarf Blue Lupine"

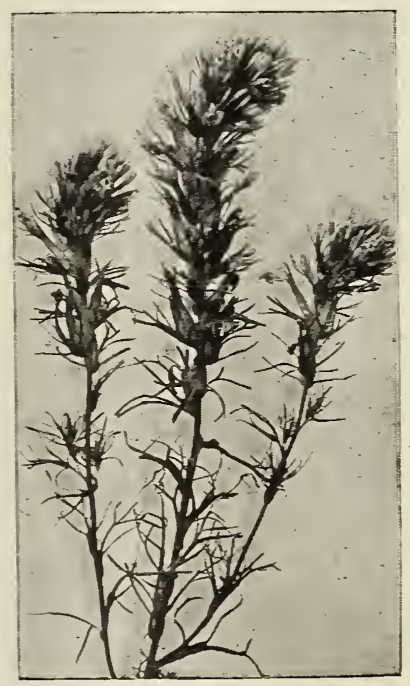

Orthocarpus purpurescens "Owl's Clover"

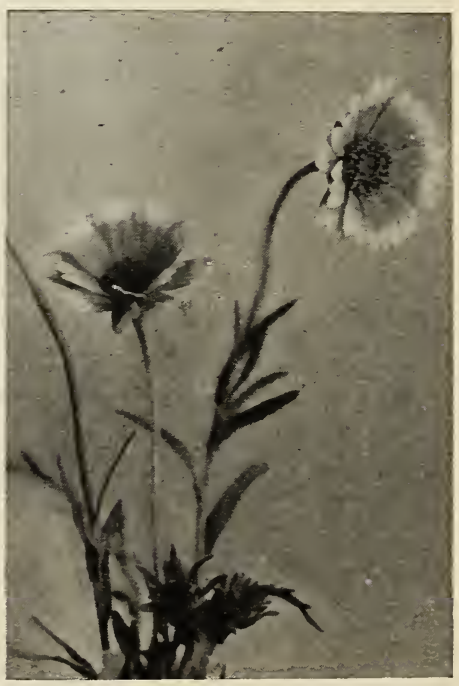

Layia elegans 


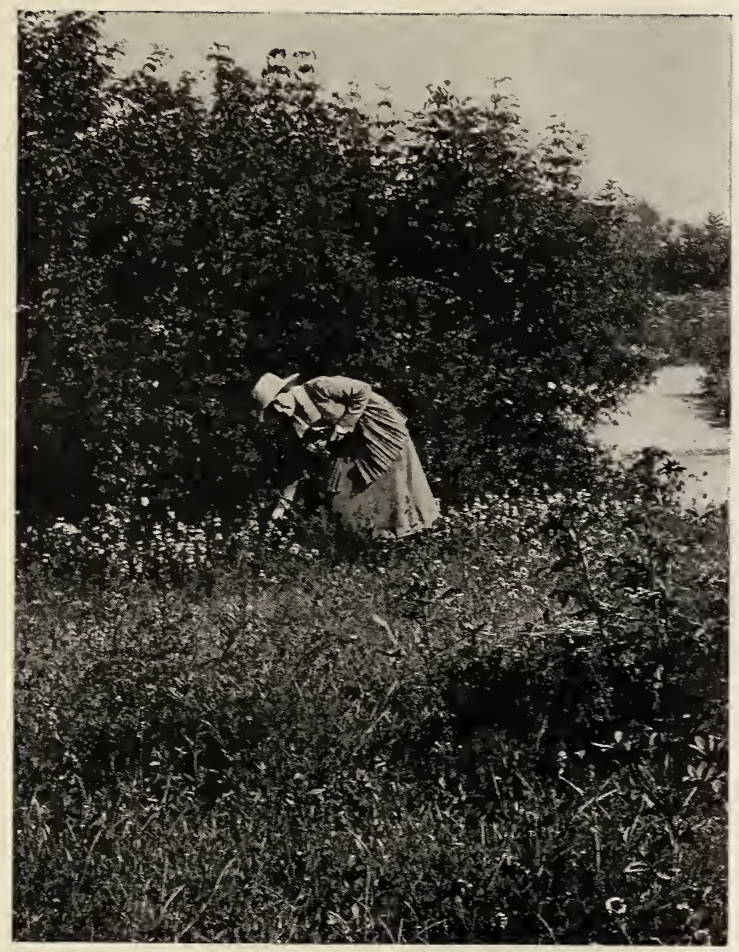

A result from our No. 1 Mixture

Lupinus eytisoides. "Canyon Lupine." Perennial, to 6 feet high. Flowers in long racemes, deep pink or rose purple and very showy. Pkt., 15c, oz. $\$ 1.00$

Lupinus densinorus. "White Lupine." Annual, 1 to $11 / 2$ feet high. A stout, branching plant with rich green follage and white flowers in dense whorls. Pkt., $15 \mathrm{c}$ oz., $70 \mathrm{c}$.

Lupinus densiflorus. (Purple-flowered form.) A form Lupinus densiforus. (Purple-flowered form.) A form
of the preceding with purple flowers. Pkt., 15c; oz., 70c.

Lupinas formosus. "Beautiful Lupine." Perennial, of spreading habit, 1 to 2 feet high. Flowers purple, blue or lilac. Pkt., $15 \mathrm{c}$.

Lupinus hirsutissimus. .."Hairy Lupine." Annual, 1 1/2 to $2 \frac{1}{2}$ feet high. Flowers large, deep reddish purple Pkt., 15c; oz., \$1.00.

Lupinus longifolins. "Blue Bush Lupine." Shrubby perennial, 3 to 4 feet high. Long splkes of light blue
flowers. Very valuable for covering dry slopes. Pkt., finwers. Very

Lupinus menziesii. "Yellow Lupine." Annual, 1 to feet high. Flowers rich yellow. Pkt., 15c; oz., 70c.

Lupinus nanus. "Dwarf Blue Lupine." Annual, 10 to 15 inches high. A very showy plant: flowers rich blue and white, fragrant. Pkt., 10c; oz., 40c; lb., $\$ 5.00$.

Lupinus paynei. "Payne's Tree Lupine," Shrubby perennial, 4 to 8 feet high. Flowers fragrant, in long perennial, 4 to 8 feet high. Flowers fragrant, in long purple and white, all with a beautiful yellow blotch purple and white, all with a beautiful yellow b
on the standard. Foliage silvery grey. Pkt., 25c.

Malacothrix californica. "Wild Marigold." Annual, 6 to 12 inches high. Flowers large, resembling a calendula or marigold, cream and yellow, beautifully
blended. The blossoms are on single stems and open blended. The blossoms are on single stems and open at daylight but close later in the day. They are produced in great numbers and present a wonderful sight in the early morning sunlight. A pretty little plant doing especially well in sandy soll. Pkt., 15c; 1/4 oz.
$\$ 1.00$.

Malacothrix glabrata. "Desert Marigold." Annual 6 to 12 inches high. Flowers large, creamy yellow. Pkt., 15c; $1 / 4$ oz., $\$ 1.00$.

Meconopis heterophylla. "Flaming Poppy." Annual, 1 to 2 feet high. Flowers salmon-colored or brick red. Pkt.. $15 \mathrm{c}$.

Mentrelia laevicaulis. "Blazing Star." Biennial, 3 to 4 feet high. Flowers 3 to 4 inches in diameter, opening in the late afternoon, pale yellow. Grows in gravelly soil. Pkt., 15c; oz., $\$ 1.50$.
Mentralin lindleyi "Blazing Star," Annual, 2 to 3 feet. Showy yellow flowers. Pkt., 10c; oz., 40c; lb. $\$ 5.00$.

Mimulus brevipes. "Yellow Monkey Flower." Annual, 1 to $1 \frac{112}{2}$ feet high. Flowers large, clear canary yellow. Pkt., $15 \mathrm{c}$

Mimulus cardinalis. "Scarlet Monkey Flower." Perennial, 1 to 3 feet. Flowers bright scarlet; grows in wet places. Pkt., $15 \mathrm{c}$.

Mimulus fremonti. "Pink Monkey Flower." Annual, 4 to 6 inches high. Flowers large, deep rose pink. Grows in sandy places. Pkt., $15 \mathrm{c}$.

Mimulus lewisil. "Large Pink Monkey Flower." Perennial, 1 to 2 feet. Large rose pink flowers. Grows in wet places. Pkt., 15c.

Nemophila aurita. "Trailing Nemophila." Annual, stems 1 to 3 feet long generally trailing over underbrush on shady banks. Flowers purplish violet. Pkt., $15 \mathrm{c}$.

Nemophila insignis. "Baby-Blue-Eyes." Annual, 4 to 8 inches high. A charming little plant of spreading habit, with clear, azure blue flowers. Prefers shade or partial shade. Pkt., $10 \mathrm{c}$; oz., $35 \mathrm{c}$; 1b., $\$ 4.00$.

Nemophila maculata. "Spotted Nemophila." Annual, 4 to 8 inches. White with large deep purple blotch on each petal. Does well in shady places. Pkt., 10c; oz. $35 \mathrm{c}$; $1 \mathrm{~b} ., \$ 4.00$.

Oenothera bistorta vietchiana. "Sun Cups." Annual, of low trailing habit. Flowers large, bright yellow. Grows in sandy places. Pkt., $15 \mathrm{c}, \mathrm{oz}$. $\$ 1.50$.

Oenothera hookeri. "Yellow Evening Primrose." Biennial, 3 to 6 feet. Flowers large, light yellow. Pkt., 10c; oz., 60c.

Oenothera trichocalyx. "White Evening Primrose." Riennial 1 to 1 1/ fept high Grows in sandy soil. Pkt., 15c; $1 / 4$ oz., $\$ 1.00$.

Orthocarpus purpurascens. "Owl's Clover" or "Pink Paint Brush." Annual, 4 to 10 inches high. Rose, pink nr purnlish lilar shading to cream-color at center. Pkt., 10c; oz., $\$ 1.50$.

Papaver californicum. "Western Poppy." Annual, 1 to 2 feet. Flowers orange-scarlet with pale yellow center. Pkt., $25 \mathrm{c}$

Pentstemon antirrhinoides. "Yellow Pentstemon." Perennial shrub, 3 to 4 feet high. Flowers large, bright yellow. Pkt., 15c.

Pentstemon centranthifolius. "Scarlet Bugler." Perennial, 2 to 4 feet hlgh. Rich vermilion colored flowers. Pkt., $15 \mathrm{c}$.

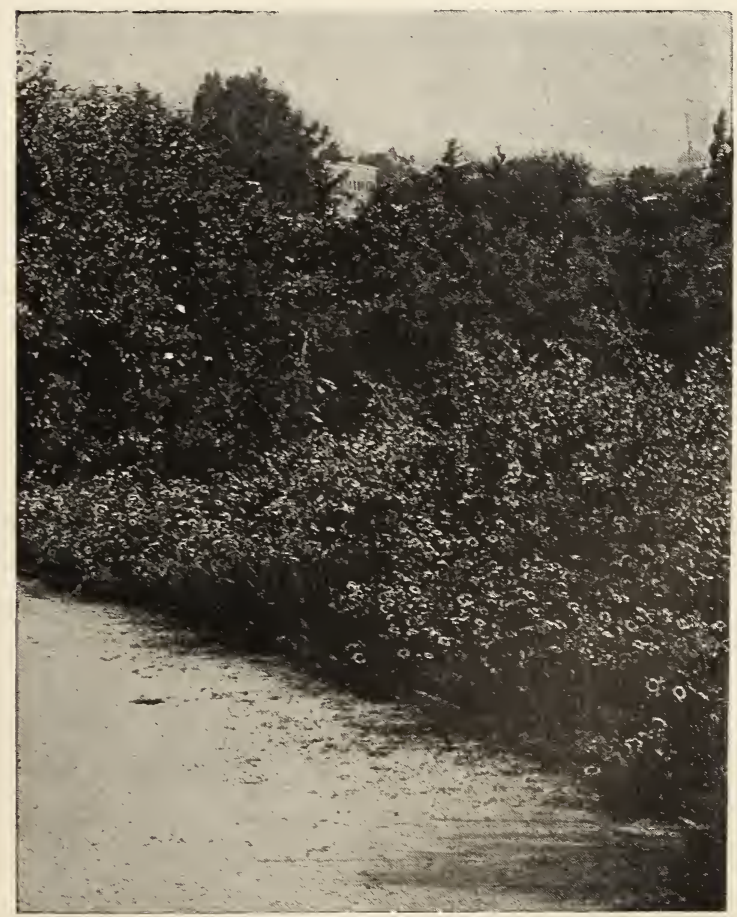

An ideal setting for Wild Flowers 


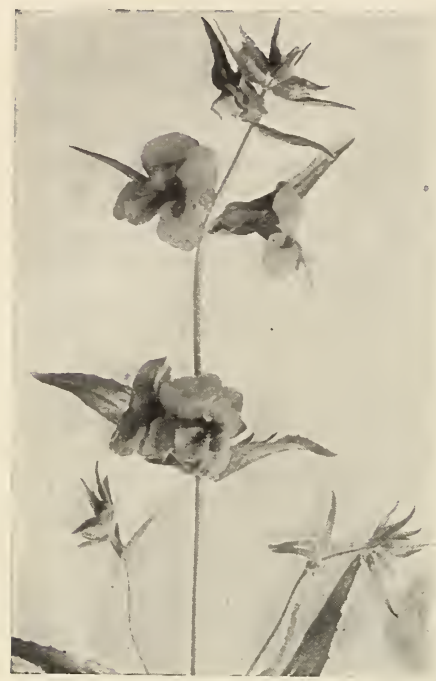

Mimulus brevipes

"Yellow Monkey Flower"

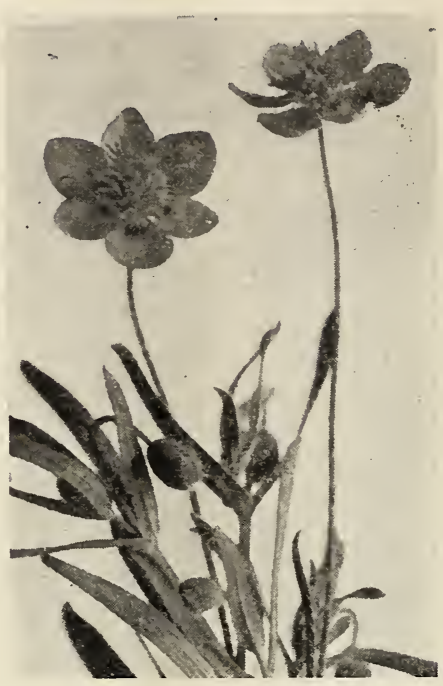

Platystemon californicus "Cream Cups"

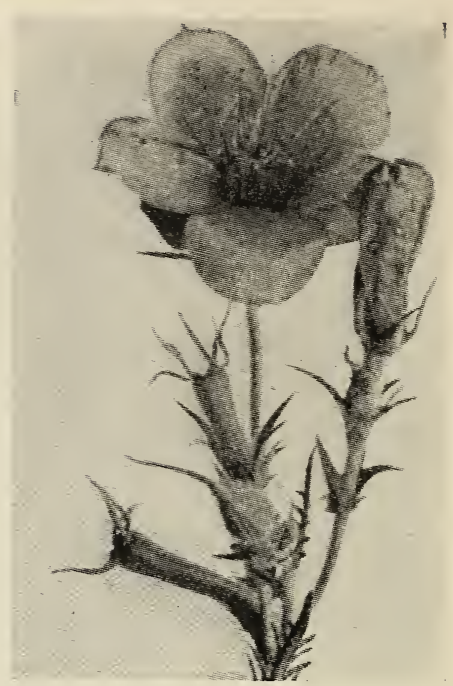

Mentzelia lindleyi "Blazing Star"
Pentstemon heterophyllus. "Violet Beard Tongue." Perennial, $1 \frac{1}{2}$ to 2 feet high. Flowers trumpet shaped. royal purple marked with pink. Pkt., $15 \mathrm{c}$.

Pentstemon palmeri. "White Pentstemon." Perennial, $1 \frac{1 / 2}{2}$ to $2 \frac{1}{2} \mathrm{ft}$. high. Flowers large, creamy white shaded with pink. Pkt., $15 \mathrm{c}$

Pentstemon spectabilis. "Biae Pentstemon." Perennial, 4 to 7 feet high. Flowers in long spikes, and the richest combination of blue and royal purple. Pkt., 10c; oz., $\$ 1.00$.

Phacelia campanularia. "Bell-flowered Phacelia." Annual 1 to $1 \frac{1}{3}$ feet high. Flowers intense bright blue. Pkt., 15c; oz., $\$ 1.00$.

Phacelia grandiflora. "Large Flowered Phacelia." Annual, 1 to 3 feet high. Large saucer-shaped flowers. lavender, beautifully veined with violet. Pkt., 10c; oz., $70 \mathrm{c}$.

Phacelia parryi. "Parry's Phacelia." Annual, 1 to $11 / 2$ feet high. Flowers saucer-shaped, deep violet, generally with five yellow spots. Pkt., 10c; oz., 70c; lb. $\$ 8.00$.

Phacelia tanacetifolia. "Wild Hellotrope." Annual, $1 \frac{1 / 2}{20} 21 / 2$ feet high. Flowers lavender blue. Pkt., 10c; oz., $35 \mathrm{c}$; lb., $\$ 4.00$.

Phacelia visida. .-.Sticky Phacelia." Annual 1 to 2 feet high. Flowers saucer-shaped, rich salvia blue. Pkt., 10c; oz., 70c; 1b. $\$ 8.00$.

Phacelia whitlavia. "Wild Canterbury Bell." Annual, 1 to $11 / 2$ feet high. Large bell-shaped flowers hanging in open, airy clusters; color violet purple. Pkt., 10c; oz., 60c; 1b., \$7.00.

Platystemon callernicus. "Cream Cups." Annual, 6 to 10 inches high. Cream colored flowers. Pkt., 10c; oz., $\$ 1.50$.

Ranunculus callernicus. "California Buttercup." Perennial, 1 to $11 / 2$ feet high. Flowers golden yellow. Generally found on grassy slopes on the north side of the foothills. Pkt., 15c.

Romneya coulteri. "Matilija Poppy." Perennial, 6 to $10 \mathrm{feet}$ high. Blossoms often 6 or 7 inches in diameter, pure glistening white with bright yellow centers. Pkt., 15c.

Salvia carduacea. "Thistle Sage." Annual, 1 to 2 feet high. Pale lavender flowers. Pkt., 10c; oz., 50c; lb., $\$ 6.00$.

Salvia columbariae. "Chia." Annual, 9 to 15 inches high. Flowers in whorls, deep purple. Pkt., $15 \mathrm{c}$.

Silene laciniata. "Indian Pink." Perennial, 1 to 3 feet. Flowers bright scarlet. Pkt., 15c.

Sisyrinchium bellum. "Blue Eyed Grass." Perennial, 8 to 15 inches high. Flowers bright blue with yellow centers. Pkt., 15c; oz., $\$ 1.50$.

Sphaeralcea ambigua. "Desert Mallow." Shrubby perennial from Mojave Desert. Grayish green foliage; fowers salmon buff, very howy. Pkt., 15c.
Trichostema lanatum. "Romero" or "Woolly Blnecurls." Shrubby perennial 4 to 6 feet high. Flowers curls." Shrubby perennial, 4 to
rich blue. Pkt., 15c; oz., $\$ 2.00$.

Verbascum virgatum. "Mullein." Biennial, 5 to 6 feet high. Flowers in long spikes, rich yellow. Plet., 10c.

Verbesina encelloides. "Crownbeard." Annual, of branching habit, 2 to 5 feet high. Flowers large, resembling a coreopsis, orange yellow, very showy. Pkt., 15c.

Viola pedunculata. "Yellow Violet," Perennial, 4 to 8 inches high. Flowers yellow, the two upper petals blotched with brown on the outside. Pkt., 15c.

Zauschneria microphylla. “California Fuchsia." Perennial, 1 to $1 \frac{1}{2}$ feet high. Scarlet trumpet-shaped flowers. Useful for covering dry banks. Pkt., $15 \mathrm{c}$.

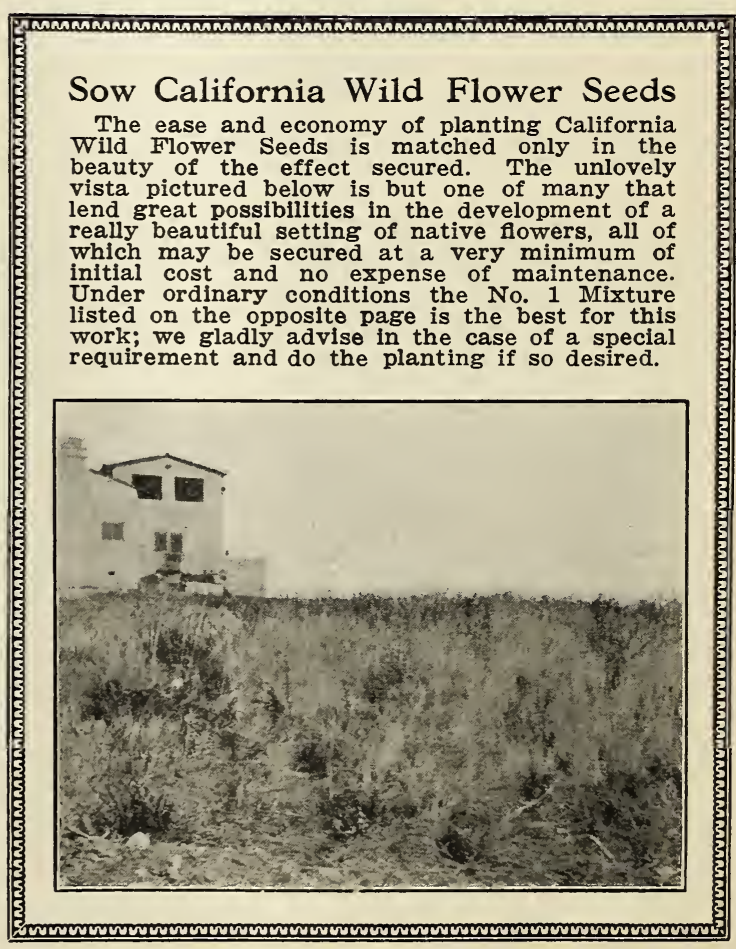




\section{CaliforniaWildFlowerSeed Mixtures}

The mixtures numerically listed below are a result of twenty-five years of observation and intensive study of the native flora of California, both from scientific and practical standpoints. They contain only the true wild species, and are mixed in the right proportions to produce a succession of flowers over a long period. All are annual varieties, very hardy and require nothing beyond natural conditions to produce their maximum.

\section{General Mixtures}

We particularly recommend these mixtures for sowing on unused pieces of ground, parkings, racant lots, etc. The No. I Mixture has an established reputation, as the many letters of praise we have received will prove. It contains twenty distinct species mixed in their right proportions and will produce a succession of bloom for a long period. Many odd corners and unsightly pieces of unused ground can be transformed into beauty spots by sowing some of these seeds broadcast in the Fall about the time the rainy season commences.

In ordering it is only necessary to mention the number of the mixture desired.

Payne's Mixture. No. 1. General mixture of annual wild flower seeds. This mixture is made up of those kinds which vill give a succession of flowers for a long period and will will give a succession of flowers for a long period and Will succeed under or

Payne's Mixture. No. 2. Mixture of annual wild flower seeds for sowing in shady places. Pkt., $10 \mathrm{c} ; 02 ., 50 \mathrm{c} ; 1 / 4 \mathrm{lb}$., $\$ 1.75$; for $\$ 6.00$.

Payne's Mixture. No. 3. Mixture of annual wild flower seeds in orange, yellow and cream shades. Plt., $10 \mathrm{c} 0 \mathrm{z} ., 60 \mathrm{c}$ $1 / 4$ lb., $\$ 2.00 ; 1 b ., \$ 7.00$.

Payne's Mixture. No. 4. Mixture of annual wild flower seeds in blue, purple and larender shades. Pkt., 10c; oz., 50c; $1 / 4$ lb., $\$ 1.75 ; 1 \mathrm{~b} ., \$ 6.00$.

\section{Caution}

As a result of our twenty-four years of effort in bringing before the public the beauty of California Wild Flowers there is now a considerable demand for these seeds. It is a regretable fact that some seed stores have resorted to the practice of sell. ing garden varieties of flowers as wild species. Some of theere are cultivated forms of wild flowers, greatly changed, and in many cases much inferior to the original types and others are not native species at all. The No. 1 Mixture has been imitated rith in inferior mirture of such flowers and sold at a price at rith an inferior mixture of ing your seeds, be sure of getting the true wild species.

\section{How to Sow Wild Flowers}

Cultural Notes. In sowing California wild flower seeds follow nature as closely as possible, scatter the seeds broadcast over the ground and let them come up after the rains commence. Wherever practicable it is best to work up the surface of the ground and pulverize with a fine rake; afterwards the seed can be scattered broadcast over the ground. A very good time is just before a rain, or even while it is raining, if it can te so a rranged. They require practically no further attention, and will succeed with an average amount of rainfall withou artificial irrigation. In dry years, of course, watering would be beneficial, and in cases where very quick results are desired, frequent waterings will produce a quicker growth. The seeds can also be sown later on in the season up to about February, and if sprinkled frequently many species will flower quite profusely.

In the eastern states the seed should be sown in spring after danger of frost is over. Most species will prove successful there, and be highly prized.

\section{Surprise Garden Mixture}

For those who wish quantities of flower seeds for sowing on racant ground and desire a less expensive mixture than the pared a Surprise Garden Mixture which we are confident will be ound superior to any such mixture offered by other firms. It is not a mixture of wild flowers, but of garden annuals, with few wild species added. It contains a large number of different kinds, all of them quite hardy and rarieties that will grow the least amount of care and produce quantities of flowers for a long period. Indeed, there are so many kinds appearing in endless succession that it is a continual surprise from the time the first plant begins to blossom. We recommend it for tacan lots and unused pieces of ground. Pkt., 10c; oz., 35c; $3 / 4 \mathrm{lb}$. $\$ 1.20$; lb., $\$ 4.00$.

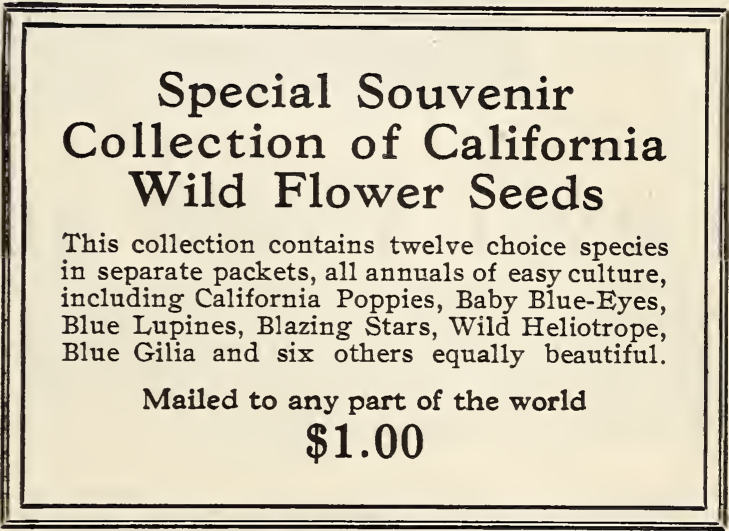

New Wild Flower Booklet

A new and enlarged edition of "California Wild Flowers Their Culture and Care," will be ready for distribution in February. Many new species and illustrations, together with detailed information on their culture and adaptability to given locations, will be the feature of this new booklet and it will prove an inwill be the feature of this new booklet and it will prove an invarnia. Price $25 \mathrm{c}$, postpaid.
for

\section{Naturalistic Gardens}

The charm of a California landscape is measured by the number of natural flowers and shrubbery that abound upon it. Barren slopes or open areas can be treated economically and attractively slopes or open areas can be treated economically and attractively with the native vegetation where an alternative would be fill cult a planting of wild flowers will stimulate interest in their holdings, a planting of wild flowers will stimulate interest in their holdings, siderably less than a mediocre campaign of advertising. Estimates furnished and correspondence invited. 


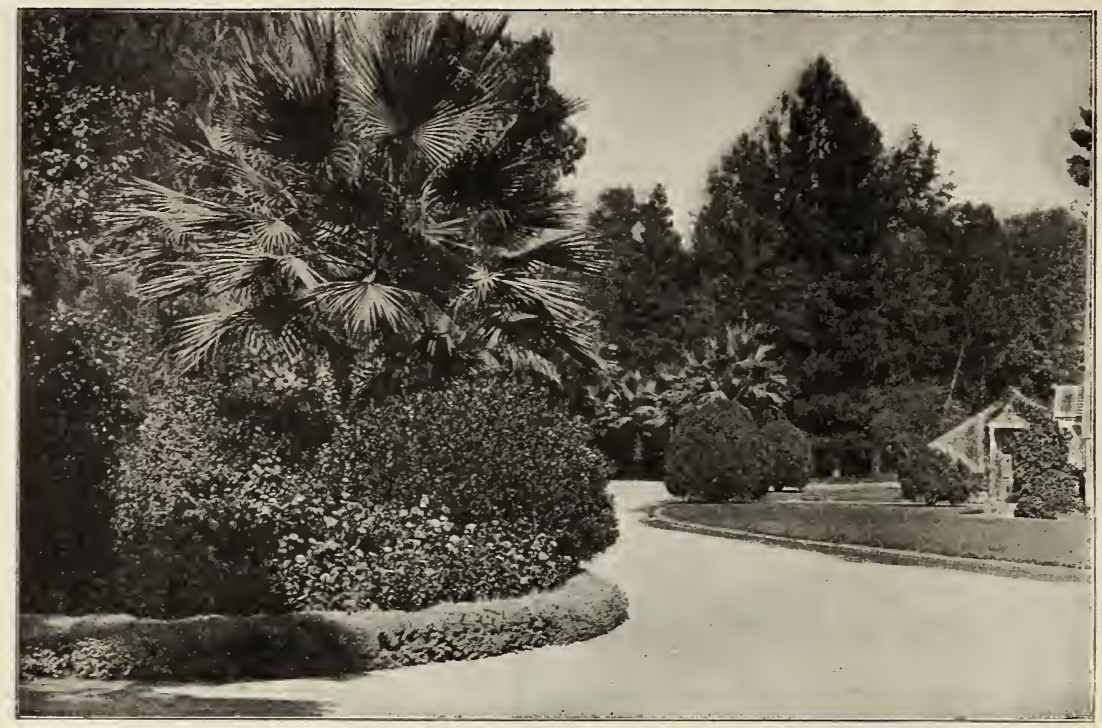

\section{Lawn Grass and Clover Seeds}

In the making of a successful lawn the first requirement is good seed. The many so-called "grades" of Blue Grass and Clover seeds with their corresponding prices often tempt the unsuspecting lawn maker into purchasing seeds that will prove very expensive in the long run. So much labor and time is necessary in the preparation of the soil that it is poor economy to try and save a few cents in buying seed of unknown quality. We carry in stock only the very best grade, and offer it to the public only after a thorough test on our own premises.

KENTUCKY BLUE GRASS. This is the grass generally used for lawns in Southern California. I handle only the best grade of seed. Lb. 60c, 10 lbs. $\$ 5.50$.

WHITE DUTCH CLOVER. Largely used for mixing with Kentucky Blue Grass, making an excellent lawn. Seed of the best quality. Lb. $80 \mathrm{c}, 10 \mathrm{lbs}$. $\$ 7.50$.

AUSTRALIAN RYE GRASS, Often used for making a quick lawn. It requires less molsture than Blue Grass, and will grow on soils where the latter will not thrive. Lb. $35 \mathrm{c}, 10$ lbs. $\$ 3.20$, postpaid.

PACIFIC RYE GRASS. Similar to the Australian Rye Grass, but finer. Recommended for lawns. Lb. $40 \mathrm{c}, 10 \mathrm{lbs}$. $\$ 3.30$, postpaid.

SHADY LAWN GRASS. This is used for sowing under trees. It makes a rich, velvety lawn, and will grow in dense shade where nther grasses will not thrive. Imported seed, lb. $\$ 1.25$.

\section{DIRECTIONS FOR MAKING A NEW LAWN}

The ground should first be spaded over, or plowed to - depth of 8 or 10 inches, and should then be leveled to the proper grade. A good plan is to let it lay for cereral weeks and water thoroughly. This will give a chance for many of the weed seeds in the ground to uprout, and these can be hoed off as they come up After the weeds have been removed, rake the surface With a ine rake, and sow the seed broadcast: Blue Grass seed at the rate of $1 \mathrm{lb}$. to $200 \mathrm{sq}$. $\mathrm{ft}$., or White Clover seed at the rate of 1 lb. to 300 sq. $f t$. When both grass and clover are used, they are generally own one-third clover to two-thirds Blue Grass. It is better to sow them separately, however, going over the ground first with one and then with the other: as in this way they can be sown more evenly than if the seeds are mixed together. After the seed has been sown, it should be covered with about half an inch of cown, it should be covered with about half an inch of good mulch. This is very essential, especially during kept continually moist, giving the seed an opportunity to germinate. The best thing to use for a mulch is thoroughly rotted manure, which has been passed through a fine screen. Great care should be taken in selecting this, and it should be taken from a pile that has been thoroughly heated, so that all the weed seeds are killed. When any other kind of manure is used, it will only bring weed seeds into the lawn. For small lawns, burlap is of ten used in place of a mulch. This is spread out over the surface of the ground, the watering being done over the burlap, which can be removed after the seed has germinated. Burlap is especially valuable on steep banks or slopes, as it both keeps the surface molst, and also prevents the seed from washing out. Watering a newly sown lawn should be done very carefully, and with a fine spray. should be done very carefully, and with a fine spray, and as often as is necessary, to keep the surface perrectly molst at all times of the day, until the seed has germinated. After the lawn is ive or six weeks best of care there are bound to be some weeds produced from seeds which have been lying dormant in the ground or blown in from vacant lots, etc. This should be done carefully, pulling out all weeds by the ronts.

To keep a lawn in good condition it should be fertilized at least once a year with a dressing of a good commercial lawn fertilizer.

\section{HOW TO RENOVATE AN OLD LAWN}

An old lawn infested, with Bermuda Grass, better known as "Devil Grass," can be restored to its earlier green and velvety appearance by the following method.

Stop watering the lawn about August 1st and allow it to remain dry about a month. Then rake out the Bermuda Grass with a special Bermuda Grass Rake which is made especially for that purpose, raking first in one direction and, after the grass has been closely clipped with a mower, rake it in an opposite direction and then mow a second time. Mix equal parts of Blue Grass and White Clover and sow broadcast over the lawn, covering about one-eighth inch of soll over the entire surface. Water several times a day during the first few days, then once a day until a good growth is started. In four to six weeks mow the lawn again and apply a light dressing of Commercial Lawn Fertilizer to insure a luxuriant growth through the winter.

\section{LAWN FERTULIZERS}

NO. 1 GRADE, COMMERCIAL LA WN FERTILIZER. Apply at the rate of 4 lbs. to 100 sq. $\mathrm{ft}$; $40 \mathrm{lbs}$. to 1000 sq. Pt. of lawn. First mix the fertilizer with about the same quantity of finely sifted soil, then scatter broad. cast over the lawn and water thoroughly. 1n lbe 60 c, 25 lbs. $\$ 1.25,50$ lbs. $\$ 2.00,100$ lbs. $\$ 3.75$, by express or freight. 


\section{Vegetable Seeds for the Home Garden}

In every home there is some decided preference for certain varieties of vegetables. Why not use that piece of ground along the back fence for growing your own? You know there is nothing so appetizing as fresh vegetables, right out of the ground, and it furnishes a real interest and healthful recreation for at least one member of the family. Select your favorite sorts from the following pages and plant a vegetable garden this year.

NOTE-All prices are postpaid anywhere in the United States; add 14c per pound on foreign orders. Write for attractive prices on large quantities.

\section{ARTICHOKE}

\section{Aleachofa-A rtischoke-Artichaut}

Culture.-Sow early in spring in beds or drills and the following season transplant 4 leet apart each way. LARGE GREEN GIOBE. The standard variety. Pkt. 10c; oz. 90c; 1/4 lb. $\$ 3.00$.

\section{ASPARAGUS}

\section{Esparago-Spargel-Asperge.}

Culture.-Soak the seed in warm water for 24 hour and sow in drills 14 inches apart; keep well watered and cultivated. The following winter transplant to rows 8 leet apart, placing the plants 18 inches apar in the row. The ground must be well manured and trenched 2 leet deep or more and the plants should be set so that when established the crowns will be 8 Inehes under the surface.

GIANT ARGENTEUIL. A lavorite varlety in the Paris markets and now in great demand in this country. Of enormous size, tender and of delicious Pkt. $10 \mathrm{c} ;$ oz. $20 \mathrm{c} ; 1 / 4$ lb. $50 \mathrm{c} ; 1 \mathrm{~b} . \$ 1.50$.

PALMETTO. The standard market variety, bright green color. Pkt. $10 \mathrm{c} ;$ oz. $20 \mathrm{c} ; 1 / 4$ lb. $45 \mathrm{c} ; 1 \mathrm{~b} . \$ 1.25$.

\section{BEANS \\ Frijoles-Bohne-Haricots Nainn \\ DWARF OR BUSH}

Culture.-After danger of frost is over plant in good mellow soll in drills 2 Inches deep and 2 feet between the rows, placing the beans 3 or 4 inches apart. One pound will sow 100 feet of row.

\section{WAX OR YELLOW PODDED}

GOLDEN WAX. Pods rather flattened, light yellow, brittle and with few strings. A standard sort and a good producer. Pkt. $10 \mathrm{c}$; $1 / 2$ lb. $20 \mathrm{c}$; $1 \mathrm{~b} .35 \mathrm{c}$.

PRULIFIC BLACK WAX. Pods bright yellow, nearly round; very early and productive. Pkt. 10c; $1 / 2$ lb. $20 \mathrm{c} ; 1 \mathrm{~b}$. $35 \mathrm{c}$

VENTURA WONDER WAX. Pods often 9 inches long, straight, oval, entirely stringless, transparently white, and of finest flavor. Hardy and productive. Pkt. 10c; $1 / 2$ lb. 20c; lb. $35 \mathrm{c}$.

\section{GREEN PODDED}

BURPEE'S STRINGLESS GREEN POD. Pods long straight, entirely stringless. brittle and of good flavor early. Pkt. 10c; $1 / 2$ lb. $20 \mathrm{c}$; 1b. $35 \mathrm{c}$.

CANADIAN WONDER, Long, flat pods, very tender prolific, and in flavor and appearance unsurpassed. prolific, $10 \mathrm{c} ; 1 / 2$ 1b. $20 \mathrm{c}$; $1 \mathrm{~b} .35 \mathrm{c}$.

LONG YELLOW SIX WEEKS. A favorite market variety. Pods green, long and tender; very early. Pkt. $10 \mathrm{c}$; $1 / 2$ 1b. $20 \mathrm{c}$; 1b. $35 \mathrm{c}$.

\section{POLE OR RUNNING BEANS}

Culture.-Plant in rich soil in hills 3 feet apart each way. Place an $8 \mathrm{ft}$. stake to each hill around which plant 5 or 6 beans and afterwards thin out to the 4 strongest plants. They are also grown in hills the apart, without poles, allowing the vines to run.

ASPARAGUS OR YARD LONG. A curious variety, Produces pods 15 to 30 inches long; excellent for the home garden. Pkt. 10c; oz. 20c.

KENTUCKY WONDER OR OLD HOMESTEAD. The most productive and best pole bean for this climate. Pods hang in large clusters, long. brittle and of fin quality. Pkt. 10c; 1/2 1b. 20c; 1b. $35 \mathrm{c}$

WHITE SEEDED KENTUCKY WONDER. A variety of recent introduction possessing all the good qualities of the old variety of that name, but having white seed. Pkt. 10c; $1 / 2$ lb. 20c; lb. 35c.

KENTUCKY WONDER WAX. The best Pole Wax bean. having all the good qualities of the green variety that name. Pkt. 10c; $1 / 2$ lb. $20 \mathrm{c} ; 1 \mathrm{~b} .35 \mathrm{c}$

SCA RLET RUNNER. A favorite variety in English gardens. Prolific and of rich flavor. Also useful as an ornamental vine: flowers are bright scarlet and very showy. Pkt. 10c; $1 / 2$ 1b. 20c; 1b. $35 \mathrm{c}$

\section{LLMA BEANS}

Culture.-Lima Beans should not be sown until after the ground is well warmed up in spring. Sow the bush varieties in rows 2 feet apart and the pole kinds in hllls 4 feet apart each way.

BURPEE'S IMPROVED BUSH. Earlier and more productive than the Burpee's Bush. Both the pods and beans are of enormous size. One of the most valuable of late introduction. Pkt. $10 \mathrm{c} ; 1 / 2 \mathrm{lb} .20 \mathrm{c} ; 1 \mathrm{~b} .35 \mathrm{c}$.

FURDHUOK BUSH LIMA. This is a variety of recent introduction, and is the most prolific lima bean ever grown. It usually grows from 20 to 24 inch high, and bears in clusters of 2 to 5 pods are round and thick averaging 4 beans to the beans a mild but delicious flavor. Pkt. $10 \mathrm{c} ; 1 / 2,1 \mathrm{~b}, 20 \mathrm{c} ; 1 \mathrm{~b} .35 \mathrm{c}$.

KING OF THE GARDEN-POLE LIMA. Produces pods 5 to 7 inches long, well filled with good-slzed beans of rich flavor. It bears heavily and is one of the best for general use. Pkt. $10 \mathrm{c} ; 1 / 21 \mathrm{~b} .20 \mathrm{c} ; 1 \mathrm{~b}$. $35 \mathrm{c}$.

MONSTROUS BUSH LIMA. The largest of all the limas and exceedingly prolific. By pruning the bushes at the right seascn, they can be made to bear at least two crops a year for several years. The beans are exceptionally fine flavored and considered by many to be the best lima bean. Pkt. $10 \mathrm{c} ; 1 / 21 \mathrm{~b}$. $35 \mathrm{c} ; 1 \mathrm{~b}$. $60 \mathrm{c}$.

\section{ENGLISH OR BROAD BEANS}

Culture.-Plant in fall or early winter in drills inches deep and 2 to 3 feet between the rows, placing the beans 6 inches apart. When in full bloom nip a few inches off the top of each stem. The plants are quite hardy and bear in winter or early spring. The beans are shelled green and cooked llke lima beans and can be had at a time of year when green lima beans are not obtalnable.

BROAD WINDSOR. An old favorite variety. Pkt. $10 \mathrm{c} ; 1 / 2$ 1b. $20 \mathrm{c} ; 1 \mathrm{~b} .30 \mathrm{c}$

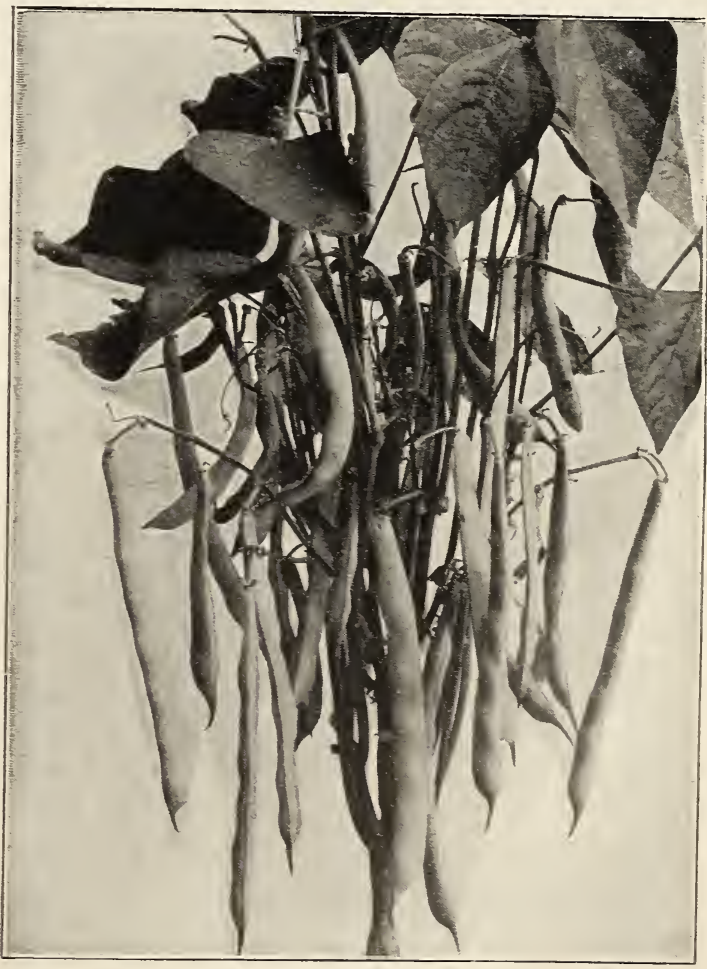

Ventura Wonder Wax Bean's 


\section{BEETS}

Remolacha-Rothe Ruebe-Betterave

Culture.-Sow in drills 18 inches apart and cover 1 inch deep. When the plants are large enough thin out to 6 inches apart. Beets can be planted in South50 feet of row.

CROSBY'S EGYPTIAN. A selection from the Extra Early Egyptian. Slightly more globe shaped than the parent. Flesh deep red and of the finest quality. Considered by many the best beet on the market. Pkt. $10 \mathrm{c} ;$ oz. $15 \mathrm{c}$; $1 / 4$ lb. $40 \mathrm{c}$; 1b. $\$ 1.25$.

DETROIT DARK RED. One of the very best for either market or home use. Tops very small; roots globe shaped, dark blood red, tender and sweet. Pkt. $10 \mathrm{c}$; oz. $15 \mathrm{c}$; $1 / 4$ lb. $40 \mathrm{c}$; $1 \mathrm{~b}$. $\$ 1.25$.

ECLIPSE. Extremely early, round, blood red, small tops. Pkt. $10 \mathrm{c}$; 0z. $15 \mathrm{c} ; 1 / 4 \mathrm{lb} .35 \mathrm{c} ; 1 \mathrm{~b} . \$ 1.00$

EDMAND'S EARLY BLOOD TURNIP, Of finest quality, extra early. Pkt. $10 \mathrm{c}$; oz. $15 \mathrm{c} ; 1 / 4$ ib. $35 \mathrm{c} ; 1 \mathrm{~b} . \$ 1.00$.

SWISS CHARD, LUCULLUS. A superior variety with large, crumpled leaves, very tender and of fine flavor. The stalks are very heavy, $11 / 2$ inches in diameter, and 10 to 12 inches are of delicious flavor. Pkt. 10c; oz. 15c; $1 / 4$ lb. $35 \mathrm{c}$; lb. $\$ 1.00$.

\section{BRUSSELS SPROUTS}

Berza de Bruselas-Rosenkohl-Chou de Bruxellew. Culture.-Sow in spring or summer in seed beds, sow a bed of 40 square feet and produce 2000 plants.

DWARF IMPROVED. The standard sort. Pkt. 10c. oz. $30 \mathrm{c}$; $1 / 4$ lb. $90 \mathrm{c}$; $1 \mathrm{~b}$. $\$ 2.75$.

\section{CABBAGE}

\section{Repollo-Koprkohl-Chon Pomme}

Culture.-Sow in seed beds at intervals for succession. The early varieties in August and each month following until April. The Drumhead varieties sow in spring for late crop. Transplant when large enough to rows $21 / 2$ feet apart and $1 \frac{1}{2}$ feet in the rows for the early sorts, and 3 feet apart each way for the late varieties. Take care to set the stems in the ground up to the first leaf. Cabbage requires a rich, well-manured soil and should be hoed or cultivated frequently, drawIng the soil slightly up around the stems. One ounce plants.

DANISH BALL HEAD. Of medium size, heads round, very solid and a good shipper. One of the best winter 1b. $\$ 1.35$; $1 \mathrm{~b}$. $\$ 4.00$.

EARLY WINNIGSTADT. The favorite market variety, both for shipping and local sale. Heads cone shaped, solid, of good size and for quality unsurpassed. Pkt. 10c; oz. 25c; $1 / 4$ lb. 80c; lb. $\$ 2.50$.

LARGE LATE DRUMHEAD. A well known late sort producing immense compact heads. Pkt. 10c, oz. $30 \mathrm{c} ; 1 / 4 \mathrm{lb}$. $\$ 1.00 ; 1 \mathrm{~b}$. $\$ 3.00$.

PREMIUM FLAT DUTCH. A favorite variety for winter, large and of excellent quality. Every stock produces a head. Pkt. $10 \mathrm{c}$; oz. 30c; $1 / 4 \mathrm{lb}$. $\$ 1.00$; lb. $\$ 3.00$.

RED DRUMHEAD. For pickling; large, deep red color and fine flavor. Pkt. $10 \mathrm{c} ; 0 z$. $35 \mathrm{c} ; 1 / 4 \mathrm{lb}$. $\$ 1.20 ; 1 \mathrm{~b}$. $\$ 3.50$.

\section{CARROT}

Zanahoria-Moehre-Carotte

Culture.-The soll best suited for this crop is a light, rich loam. Sow any time from September to end of May in drills 15 inches apart, covering the seed lightly.

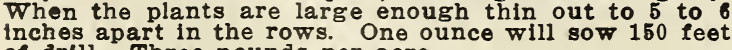
of drill. Three pounds per acre.

DANVER'S HALF LONG. A standard variety. Roots about 6 inches long. rich orange color, very symmetrical and handsome. Pkt. $10 \mathrm{c}$; oz. $20 \mathrm{c} ; 1 / \mathrm{h} 1 \mathrm{~b} .45 \mathrm{c} ; 1 \mathrm{~b} . \$ 1.25$.

EARLY FRENCH FORCING HORN. The smallest and earliest variety grown; much used for forcing. Roots nearly round. Pkt. 10c; oz. $20 \mathrm{c}$; 1/ 1b. $50 \mathrm{c} ; 1 \mathrm{~b}$. $\$ 1.50$.

IMPROVED LONG ORANGE. Very long, handsome roots, of good quality. Valuable for the table and also for stock feeding. Pkt. $10 \mathrm{c}$; oz. $20 \mathrm{c} ; 1 / 4 \mathrm{lb}$. $45 \mathrm{c} ; 1 \mathrm{~b} . \$ 1.25$.

OXHEART OR GUERANDE. The favorite table sort, often called "French Carrots." Roots about 5 inches long and 4 or 5 in diameter at the top, stump rooted. easily pulled and best for heavy soils. Pkt. 10c; oz. $20 \mathrm{c} ; 1 / 1 \mathrm{~b} .45 \mathrm{c} ; 1 \mathrm{~b}$. $\$ 1.25$.

\section{CAULIFLOWER}

Coliflor-Blumenkohl-Choufleur

Culture.-To be successfully grown this crop require very rich soil and careful cultivation. Sow in seed beds, the early varieties in August and September, and the late ones in spring; transplant and cultivate same as Cabbage. One ounce will sow a bed of 40 square feet and produce 2000 plants.

EARLY DWARF ERFURT. Of dwarf, compact habit early, a sure header. Pkt. $25 \mathrm{c}, 1 / 4$ oz. $\$ 1.00$, oz. $\$ 3.50$ $1 / 4$ lb. $\$ 10.00$, 1b. $\$ 35.00$

HENDERSON'S EARLY SNOWBALL. The most popular variety, very early and reliable header. Pkt. 25c $1 / 4$ oz. $90 \mathrm{c} ;$ oz. $\$ 2.50 ; 1 / 4 \mathrm{lb}$. $\$ 7.50 ; \mathrm{lb}$. $\$ 30.00$.

VEITCH'S AUTUMN GIANT. A large, late variety which thrives well in this section. The heads are solid, compact and well protected by the foliage. Pkt. 10c. oz. $\$ 1.35,1 / 4$ lb. $\$ 4.00$.

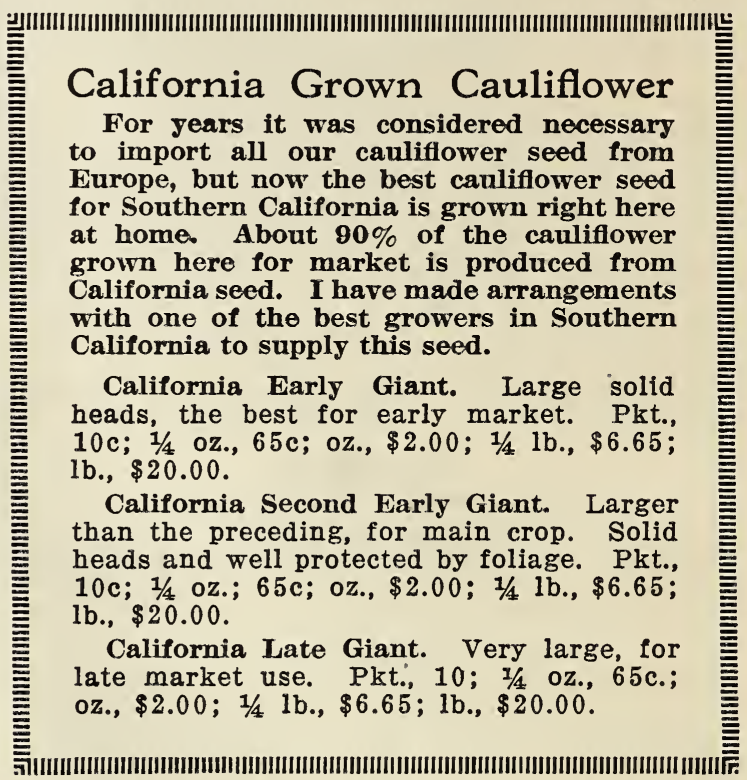

\section{CELERY}

\section{Apio-Sellerie-Celeri}

Culture.-Sow early in spring in beds of rich, mellow oil covering the seed very lightly. When 3 inches igh, prick out 4 inches apart, and when large enough transplant in well manured furrows, 4 feet apart, and about 8 inches deep. Place the plants 8 inches apart in the rows, and as the plans grow gradually flll up the currows with earth to bleach the stalks.

GOLDEN SELF-BLANCHING. (Californla-grown seed.) Pkt. 10c, oz. $80 \mathrm{c}, 1 / 4$ 1b. $\$ 2.65$, 1b. $\$ 8.00$.

WHITE PLUME. A well known sort, early, and of rich flavor. Blanches with very little earthing up oz. $40 \mathrm{c} ; 1 / 4$ lb. $\$ 1.35$; lb. $\$ 3.50$

CELERIAC OR TURNIP-ROOTED CELERY. FOTMS turnip-shaped roots, having a celery-like flavor, and is used for soups and salads; also bolled like parsnips or turnips. Pkt. $10 \mathrm{c}$, oz. $35 \mathrm{c}, 1 / 4 \mathrm{lb}$. $\$ 1.20,1 \mathrm{~b} . \$ 3.50$

\section{CHICORY}

\section{Achicoria-Cichorie-Chicoree}

Culture. Sow in spring in deep, rich soll, in drills 18 inches apart, covering the seed lightly. When the plants are large enough thin out to 8 inches apart in the rows. One ounce will sow 100 feet of drill. Much used by the French as a salad.

COMMON OR WILD. "Chicoree Amere." The roots may be transplanted in the fall into sand in a cellar. The young shoots which soon come up form the "Barbe de Capucin." a salad much used in France. Pkt. 10c. oz. $40 \mathrm{c}, 1 / 4$ lb. $\$ 1.35$, lb. $\$ 4.00$.

LARGE-ROOTED MAGDEBURG, The roots of this variety are often dried, cut into slices, roasted, ground and used for mixing with or as a sub 


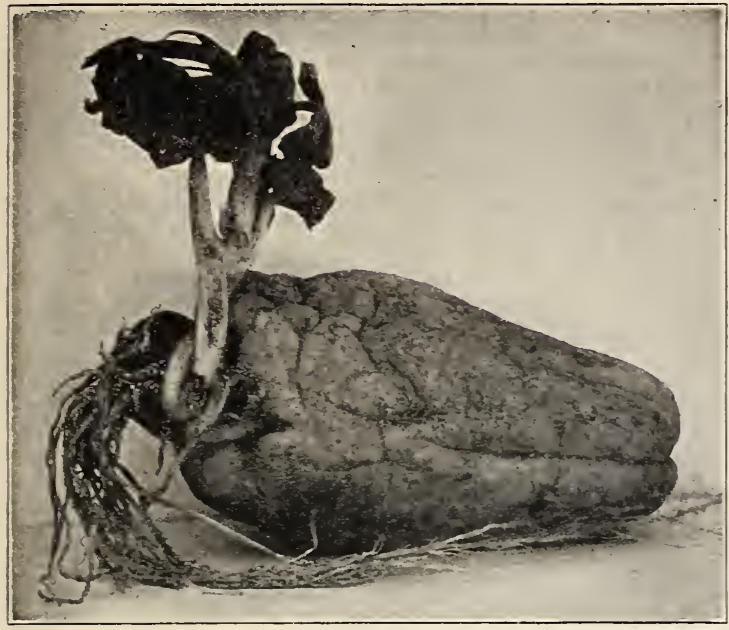

Chayote

\section{CHAYOTE}

Culture. A rapid growing perennial vine, valuable for covering fences, sheds, etc., growing thirty feet or for covering fences, sheds, etc., growing thirty feet or more in one season. It produces large quantities of fruit, which are cooked like summer squash, or fried like eggplant Each fruit contains one seed, which sprouts right out of the fruit, and the vine is propaplied from December to March. Sprouted, each, 35c.

\section{CHERVIL}

Culture. Sow early in spring in beds or drills, and Cuiture. Sow early in spring in for flavoring soups and stews and also for garnishing.

CURLED. The standard variety. Pt. $10 \mathrm{c}, 0 \mathrm{z} .40 \mathrm{c}$, $1 / 4$ lb. $\$ 1.35,1 b . \$ 3.50$.

\section{CRESS OR PEPPER GRASS}

Culture. Sow thickly, broadcast in small beds or in drills 1 foot apart, at frequent intervals for a succession. It will be ready to cut in about three weeks. grown in summer if sown in a cool, shady place. EXTRA CURLED. Leaves curled, crisp and pun-
gent. Pkt. 10c; oz. 20c; 1/4 lb. 50c; 1b. $\$ 1.50$.

\section{CUCUMBER}

\section{Pepino-Gurke-Concombre}

Cultare. As soon as the weather becomes warm and settled commence sowing for the early crop; later plantings may be made up until August. Select good rich, mellow soil, and sow in hills 4 feet apart each way, 8 to 10 seeds in a hill, covering 1 inch deep with well pulverized soil. After danger from insects is over, thin out to the four strongest plants. One ounce will plant 50 hills, or 2 pounds to one acre.

BOSTON PICKLING. A favorite for pickling, also good for slicing. Dark green, straight and well formed. kt. $10 \mathrm{c}$; 0z. $20 \mathrm{c} ; 1 / 4 \mathrm{lb}$. $50 \mathrm{c}$; ib. $\$ 1.50$.

DAVIS PERFECT. This splendid variety, introduced a few years ago, has now become very popular. The fruits are very symmetrical, 8 to 10 inches in length, dark glossy green, tender and of exceptionally fin flavor. Pkt. 10c; oz. 20c; 1/ 1b. 60c; 1b. \$1.75.

IMPROVED LONG GREEN. A standard sort. 12 to 16 inches long, dark green, firm and crisp. Pkt. $10 \mathrm{c}$ oz. $20 \mathrm{c} ; 1 / 4 \mathrm{lb}$. $60 \mathrm{c} ; \mathrm{lb}$. $\$ 1.75$.

IMPROVED WHITE SPINE. A vigorous grower early and productive. Fruit straight, light green with a few white spines: one of the best for table use. a few white spines: one of the b
Pht. 10c; oz. 20c; $1 / 4$ lb. $50 \mathrm{c} ; \mathrm{lb}$. $\$ 1.50$.

JAPANESE CLIMBING. One hill will cover a trellis 10 feet square. The fruits are dark green. excellent for table use or pickling. Pkt. 10c; oz. $20 \mathrm{c} ; 1 / 4 \mathrm{lb}$. $65 \mathrm{c}$.

LEMON CDCUMBER. Quite distinct from other cucumbers, and in shape much resembling a lemon. It a fine flavor. It is a good shipper, and also one of the best for the home garden. Pkt. 10c; oz. 25c; $1 / 4$ 1b. $85 \mathrm{c}$; best for
lb. $\$ 2.50$.

\section{CORN}

\section{Maiz-Welsckorn-Mais}

Culture. Sow any time from March to end of June, In drills or hills. The smaller varieties may be planted in drills 3 feet apart and 1 loot apart in the rows, or in hills 3 leet apart each way, covering the seed about 2 inches. The taller varieties, 4 feet by 15 inches, or in hills 4 feet apart each way. Corn thrives best in a tivate well so as to keep the ground loose, and draw it up slightly around the roots.

BLACK MEXICAN. The kernels are white when young or at the age when sultable for cooking, but when ripe and dry turn to a bluish black color. Thrives well in this climate; is very productive and the sweetest corn grown. Pkt. $10 \mathrm{c} ; 1 / 2$ lb. $20 \mathrm{c}$; 1b. $35 \mathrm{c}$

COUNTRY GENTLEMAN. A favorite for home use. It is a very small cob, closely covered with deep, narrow kernels, which are extremely tender and sweet. Ears average 8 to 9 inches in length and from 3 to 4 on
a stalk. Pkt. $10 \mathrm{c} ; 1 / 2 \mathrm{lb}$. 20c; 1b. $35 \mathrm{c}$.

EXTRA EARLY ADAMS. Not a true sweet corn, but planted for table use. Pkt. 10c; 1/ 1b. 20c; 1b. 35c.

GOLDEN BANTAM. An extra early dwarf variety. Ears of medium size, thickly set with rich yellow kernels of a most delicious flavor. This variety has become a general favorite on account of its earliness,

OREGON EVERGREEN. This is without doubt the best sweet corn ever grown, and is a great favorite among market growers in this section. It is very productive, bearing long, well-filled ears, and is of a particularly fine flavor. Many varieties of sweet corn do not thrive as well in California as in the East, and it not thrive as well in California as in the East, and it has sometimes been said that good sweet corn is not to be had here. This variety, however, seems particularly adapted to our local conditions, and produces lb. $35 \mathrm{c}$.

\section{CORN SALAD}

Macha o Valerianilla-Lammer Salat-Mache

Culture. Commonly called Lamb's Lettuce. Can b. sown nearly all the year round in California. Sow in shallow drills 1 foot apart.

LARGE ROUND LEAVED. Pkt. $10 \mathrm{c}, 0 \mathrm{z}, 30 \mathrm{c} .1 / \mathrm{l}$ lb. $\$ 1.00$, lb. $\$ 3.00$.

\section{DANDELION}

\section{A margon-Kuhblume-Pissenlit}

Culture. May be grown any time, in drills 12 inches apert, covering the seed very lightly. Much esteemed as a salad. LARGE LEAVED. Pkt. $10 \mathrm{c}$, oz. $\$ 1.50$.

\section{EGG PLANT}

\section{Berengena-Eierpflanze-Aubergine}

Culture. Sow from February to June in rich soll composed of leaf mold and sandy loam. The earlier sowings should be in a hot bed; the seed germinates very slowly, and should be kept in a warm, even temperature. When 2 or 3 inches high, transplant into small pots and place in a frame, gradually harden off. and when the weather is warm and settled transplant to the open ground. Select light, rich soil, and plant 4 feet apart each way: when about 1 foot high draw the earth up slightly around the roots.

BLACK BEAUTY. Large, rich, dark purple, very early. Pkt. $10 \mathrm{c}, 0 \mathrm{z}, 75 \mathrm{c}, 1 / 4$ lb. $\$ 2.50,1 \mathrm{~b} . \$ 7.50$

NEW YORK IMPROVED PURPLE. The leading variety both for market and home use. Pkt. $10 \mathrm{c}, 0 \mathrm{z} .75 \mathrm{c}$, $1 / 6$ lb. $\$ 2.50,1 \mathrm{~b}$. $\$ 7.50$.

\section{ENDIVE}

Escarola o Endibia-Endivien-Chicoree

Culture. May be sown in drills 15 inches apart any time during the year. When a few inches high, thin out the plants to 10 inches apart, or transplant to other rows. As soon as the plants have reached a good size. gather the ends of the outer leaves together and tie at the top so as to blanch the inside leaves. One ounce will sow 150 feet of drill.

BROAD LEAVED BATAVIAN. (Scarolle.) Leaves light green. broad and nearly plain. When blanched. makes an excellent salad. It is also used for flavoring soul and stews, and is sometimes cooked as greens. Pkt. 10c: oz. 20c; 1/ 1b. 70c; 1b. $\$ 2.00$.

FRENCH MOSS CURLED. (Chicoree Frisee.) Leaves deeply cut and curled, giving it a moss-11ke appear-
ance. Pkt. 10c; oz. $20 \mathrm{c} ; 1 / 4$ b. $70 \mathrm{c} ; 1 \mathrm{~b}$. $\$ 2.00$. 


\section{KALE OR BORECOLE}

\section{Col-Blaetterkohl-Chou Vert}

Culture. Sow the seed in beds from July to March; when large enough, transplant to rich, mellow ground and cultivate same as Cabbage. One ounce of seed will produce 2000 plants.

TALL GREEN CURLED SCOTCH. Grows from $1 \frac{1}{2}$ to 2 feet high; the variety most generally used. Pkt. $10 \mathrm{c}$ : oz. 25c; $1 / 4$ lb. $65 \mathrm{c} ; 1 \mathrm{~b}$. $\$ 2.00$.

THOUSAD HEADED. A heavy bearing variety with sunoth leaves. Used for pultry and stock food. Pkt. 10c; oz. 20c; 1/4 1b. $45 \mathrm{c}$; 1b. $\$ 1.25$.

\section{KOHL RABI}

Colinabo-Kohlrabl-Chou-rave

Culture. Sow in drills 2 feet apart any time from July to April. When large enough, thin out to 1 foot apart in the rows. One ounce will sow 150 leet of drill. EARLY WHITE VIENNA. Greenish white outside, flesh white and tender. Pkt. $10 \mathrm{c} ; 0 \mathrm{z} .30 \mathrm{c} ; 1 / 4 \mathrm{lb} . \$ 1.00$; lb. $\$ 3.00$.

EA IILY PURPLE VIENNA. Similar to the above, but of purple color. Pkt. $10 \mathrm{c}, 0 z .30 \mathrm{c}, 1 / 41 \mathrm{~b} . \$ 1.00,1 \mathrm{~b}$. $\$ 3.00$.

\section{LEEK}

Puerro-Lauch-Polreau

Culture. Sow in good rich soil any time from September to April in drills 15 inches apart and $1 / 2$ inch deep, and thin out to 10 inches apart. One ounce will sow 100 feet of drill.

LON DON FLAG. Large and uniform in shape A lb. $\$ 3.50$.

\section{LETTUCE}

\section{Lechuga-Salat-Laltue}

Culture. Can be sown at any time in California, in drills 15 inches apart, covering the seed very lightly; when large enough, thin out to 1 foot apart in the
rows. Or the seeil may be sown in beds and transplanted. The latter is preferable for summer planting. as the seed requires a great deal of moisture to germinate, and when sown in a bed it can bo kept moist by spreading burlap or sacks over the surface of the ground ard sprinkling well twice a day; after the seed is germinated the sacks may be removed, but care must be taken to keep the plants well watered. One ounce will produce about 3000 plants.

BIG BUSTON. One of the best for California; succeeds well under great variations of temperature. Heads large, solid, crisp and tender. Pkt. 10c; 0z. 25c; $1 / 1 \mathrm{~b}, 85 \mathrm{c} ; 1 \mathrm{~b} . \$ 2.50$.

EARLY CURLED SIMPSON. Large, curly leaves, forms large, loose heads; a favorite early sort. Pkt. $10 \mathrm{c}$; 0z. $20 \mathrm{c} ; 1 / 4$ lb. 50c; lb. $\$ 1.50$.

ICEBERG. A popular summer variety; heads well, even in the hottest weather; large, crisp and remarkably solid. Pkt. $10 \mathrm{c}$; oz. $20 \mathrm{c} ; 1 / 4$ lb. $65 \mathrm{c} ; 1 \mathrm{~b} . \$ 2.00$.

LUS ANGELES MARKET, OR NEW YORK SPECIAL. This lettuce is largely grown by market gardeners, and is the best selling lettuce in the Los Angeles market, while large quantities are shipped to other points as ar north as Portland and east to Salt Lake Clty and Denver. It forms a very large, perfectly solid head. Tho outer leaves are green, but after stripping these off there remains a large, white, solif head, which is very crisp and tender. Pkt. 10c; oz. 25c; 1/4 lb. 85c; lb.

PARIS WHITE Cos. (Romaine.) Long, mooth leaves, remarkably crisp and tender. The outer leaves should be drawn together and tied at the tips about 10 days before cutting, in order to blanch the inside leaves. Pkt. $10 \mathrm{c}$; 0z. $20 \mathrm{c} ; 1 / 4 \mathrm{lb} .65 \mathrm{c}$; 1b. $\$ 2.00$.

\section{MUSHROOM SPAWN}

Seta-Schwamm-Champlgnon

CuIture. Mushrooms can be grown in cellars or sheds, where a temperature of 60 to 70 degrees can be maintained. Procure some good rich loam and some fresh horse manure, and mix thoroughly together, using twothirds of the horse manure and one-third of the loam. Make a bed of this mixture about 18 inches deep, which should be pressed down firmly. As soon as the temperature of this bed falls to about 70 degrees the spawn may be inserted in pleces about one inch spawn may be inserted in pleces about one inch square. Cover the spawn with good loam about two with a layer of loose straw. If the conditions are right with a layer of loose straw. If the conditions are right the mush

ENGLISF MUSFROOM SPAWN. In bricks of about

\section{MUSKMELON}

Melon Almircleno-Cantalupen-Muscade

Culture. May be planted from March to end of June. Select light, warm soil and plant in hills 6 feet apart each way, from 6 to 8 seeds in a hill and 1 inch deep. When large enough, thin out to the three strongest plants. One ounce will sow about 100 hills.

BURRELL'S GEM. Oval, of medium size and deeply netted. The flesh is salmon-colored and of the finest flavor. Pkt. $10 \mathrm{c}$; oz. $20 \mathrm{c}$; $1 / 4$ lb. $50 \mathrm{c} ; 1 \mathrm{~b}$. $\$ 1.50$.

GA UTIER'S PINEAPPLE. This is the favorite melon on the Los Angeles market. Oval, skin thickly netted: flesh green and of delicious flavor. Pkt. $10 \mathrm{c} ; 0 \mathrm{z} .20 \mathrm{c}$; lb. $60 \mathrm{c} ; 1 \mathrm{~b}$. $\$ 1.75$.

HONEY DEW. This new melon is the latest and best development in melon culture. Outer skin smooth hard and creamy white, flesh light green, very solid and of rich honey flavor. Pkt. 10c; oz. 25c; $1 / 4$ 1b. $75 \mathrm{c}$; lb. $\$ 2.25$.

PERSIAN. New yellow-fleshed variety, sweet distinct flavor. Heavily netted but smooth rind. Good keeper and a money maker. Pkt. 10c; 0z. 50c; $1 / 41 \mathrm{~b}$. $\$ 1.65 ; 1 \mathrm{~b}$. $\$ 5.00$.

TIP TOP. Almost round, of medium size. Flesh yollow, firm and of delicious flavor, edible almost to the rind. A melon of attractive appearance, selling quickly in all the markets. Pkt. 10c; oz. 20c; $1 / 41 \mathrm{~b} .60 \mathrm{c}$; lb. $\$ 1.75$.

KUCKY FORD. Slightly oval in shape, finely netted, very regular and even in size, weighing about $1 \frac{1}{2}$ pounds; flesh light green in color and of delicious Colorado, but now grown in immense quantities in the Coachella and Thermal districts, producing the eanliest melons in the United States and shipped east by the melons in the United States and shipped east
carload. Pkt. 10c; oz. 20c; 1/4 lb. 50c; 1b. $\$ 1.50$.

\section{CASABAS}

CASABA, OR WINTER PINEA PPLE. Large, oval, kin corrugated, grayish green color; flesh firm, light green and of a delicious pineapple flavor. A very late variety: the melons do not usually ripen on the vines, but should be picked and stored in a cool, dry place, and if carefully handled may he kept till late in place, and if carefully handled may he kept till lat
the winter. Pkt. 10c; oz. 20c; $1 / 4$ lb. 70c; lb. $\$ 2.00$.

GUlukn hea UTY. Similar to the Winter Pineapple, but of a beautiful golden-yellow color. It is a good keeper, and on account of its handsome appearance it is one of the best of the winter melnne market purposes. Pkt. 10c; oz. 20c; 1/4 1b. 65c; lb. $\$ 2.00$.

IMPROVED HYBHID CASABA. Deep green and heavily ribbed, of medium size; flesh thick and of a fine quality. Pkt. $10 \mathrm{c}, 0 \mathrm{z}, 25 \mathrm{c}, 1 / 4 \mathrm{lb}$. 85c, lb. $\$ 2.50$.

SANTA CLA US. A very late variety. Oblong, mot. tled yellow and green, flesh light green and of rich fla vor. Pkt. $10 \mathrm{c}, 02.25 \mathrm{c}, 1 / 4 \mathrm{lb}$. $85 \mathrm{c}, 1 \mathrm{~b}$. $\$ 2.50$

MARKET GARUENERS - Write for attractive prices on large quantities. Use the order sheet for your want llst and we will gladiy quote the latest market prices.

\section{WATERMELON}

\section{Sandia-Wawernelone-Melon d'Eau}

Culture, Plant from March to July, in good, light sandy loam, in hills 8 to 10 feet apart each way and from 10 to 12 seods in a hill; cover the seed from 1 to inches deep, but not more. When large enough, thin out to the three strongest plants.

CHILIAN. Of medium size, almost round, dark green, slightly mottled with blackish green, rind thin, not over a quarter of an inch thick, but very hard and never cracks in shipping. Flesh solld, crisp and deep crimson clear through. This is the favorite Los Angeles
$\$ 1.50$.

BLACK SEEDED CHILIAN. This is preferred by some to the preceding variety and is consldered little earlier. Pkt. $10 \mathrm{c}$; oz. $20 \mathrm{c} ; \mathrm{i} / 4 \mathrm{lb}$. $50 \mathrm{c}$; $1 \mathrm{~b}$. $\$ 1.50$.

KLECKLEY sWEET. One of the finest melons for home use. Oblong in form, 18 to 20 inches long and 10 to 12 inches in diameter. Skin dark, rich green z. $20 c$

KLONDYKE, OR PASA DENA. Of recent introduction and a great favorite in the Pasadena market. Oblong. dark rich green, flesh bright red, very crisp and sweet. Pkt. $10 \mathrm{c}, 0 \mathrm{z}, 25 \mathrm{c}, 1 / 4$ lb. $85 \mathrm{c}$, lb. $\$ 2.50$ 


\section{MUSTARD}

\section{Mostaza-Senf-Moutarde}

Culture. Sow in drills 1 foot apart at frequent intervals for succession. Used for greens and cooked like Spinach, sometimes cut when about 2 inches high and used as a salad, generally with Cress.

SOUTHERN CURLED. Very large leaves, often 15 inches in length; the best sort for greens. Pkt. 10c oz. $20 \mathrm{c} ; 1 / 4$ 1b. $40 \mathrm{c}$; $1 \mathrm{~b}$. $\$ 1.25$.

\section{OKRA}

\section{Qnimbombo-Essbarer-Gombo}

Cultare. Sow from March to July, in drills 3 fee apart, covering the seed 2 inches deep; thin out the plants to 10 inches apart in the rows, cultivate well, and draw the earth up slightly around the stems. One ounce of seed will sow 50 feet of row.

EARLY DWARF. Of dwarl, stocky growth, very prolific, producing pods 10 days earlier than the tal varieties. Pods long and smooth. Pkt. 10c; oz. 20c $1 / 4$ lb. $45 \mathrm{c}$; lb. $\$ 1.25$.

WHITE VELVET. Of tall growth; long, round smooth pods with a whitish, velvety covering. Th 1b. $45 \mathrm{c} ; 1 \mathrm{~b}$. $\$ 1.25$.

\section{ONION}

\section{Cebolla-Zwiebel-ognon}

Culture. Onlons require a rich, molst soil; rich, low land is best. It may be either sandy loam or black soll but should have plenty of natural molsture. Land which has been planted to vegetables-peas or beans wreferred-for a few seasons is the best land for preferred-for a few seasons is the best land for onions. They may also be grown on higher lands with not be allowed to get dry, as this will check the growth not be allowed to get dry, as this will check the growth "stin necks." For the home garden the seed may be planted the year round in Californla. but for main crop from November to end of January is best. In naturally moist solls the seed may be sown in drills 15 Inches apart, covering the seed very lightly. When large enough, the plants may be thinned out to 5 or 6 inches apart in the rows. For Irrigated lands sow the seed thickly in beds or drills and keep well watered; when the plants are large enough-about half the size of a lead pencil-transplant to rows 15 inches apart and 6 inches in the rows. Trim off about a third of the tops and half the roots before planting. as this helps the plants to bulb out. When sown in drills, and the plants to bulb out. When sown in drills, and thinned out, it requires trom to 5 pounds of seed to in bed and transplanted, from 1 to 1 is pound 80 will In beds and transplanted, from 1 to $1 \frac{1}{12}$ pounds will ralse enough plants for an acre. For the home garden, Onion sets are often planted. These will produce large "Spring" Onlons, sow the seed of the White Queen or some other white variety.

AUSTRA IIAN BROWN. A favorite market sort of good size and shape: very hardy, early. productive, and the best keeper. The skin is thlek and of a rich hrown color; flesh solid and of mild flavor. Pkt. 10c; oz. 20c; $1 / 4 \mathrm{lb}$. $70 \mathrm{c} ; \mathrm{lb}$. $\$ 2.00$.

CRYSTAL WAX. A pure white varlety of the Bermuda type, very flat and extremely early. On account of its handsome appearance, earliness and mild flavor it is in great demand hy market growers. Pkt. 10c. oz. $60 \mathrm{c} ; 1 / 4 \mathrm{lb} . \$ 2.00 ; 1 \mathrm{~b} . \$ 6.00$.

LARGE RED WETHEKSFIELD. Large, slghtly flattened, deep purplish red, flesh firm and thick. This is the best known of the red varietles and largely planted. It is a heavy cronper and an excellent keeper. Pkt. 10c; oz. 25c; $1 / 4$ lb. $85 \mathrm{c} ; 1 \mathrm{~b}$. $\$ 2.50$

PRIZETAKER. A globe-shaped onton, with light yellow skin and white flesh of a mild flavor. It is popular as a market variety, a falrly good keeper, and an Immense yielder: onlons often weigh two or three pounds. and have heen knnwn tn weigh as misch as four pounds. Pkt. $10 \mathrm{c}$; oz. $25 \mathrm{c}$; $1 / 4$ lb. $85 \mathrm{c} ; 1 \mathrm{~b}$. $\$ 2.50$.

WHITE PORTUGAL, OR SILVER SKIN. A very popular varlety, both for market and home use. It is of attractive appearance. flattened but quite thick; skin sllvery white and very thin: fiesh firm snowy white and mild. A good keeper and heavy yielder; onlons of large size Also nne of the hest ylelder; onlons of $10 \mathrm{c} ;$ oz. $40 \mathrm{c}$; $1 / 4 \mathrm{lb}$. $\$ 1.35 ; 1 \mathrm{~b}$. $\$ 4.00$.

YELLOW BERMUDA. Very similar to Crystal Wax in size and flavor. Color is a light straw yellow. A heavy producer of uniform quality onions at a time when prices are good. Pkt. 10c; oz. 40c; $1 / 4$ lb. $\$ 1.35$; lb. $\$ 4.00$.

\section{ONTON SETS}

Australian Brown, White and Yellnw Sets. Per lb. 40c. Price on large quantities on application.

\section{PARSLEY}

\section{Perijil-Peterwille-Perwi}

Culture. May be sown the year round in Callfornis. Sow in good, rich soil, in drills 15 inches apart, covering the seed about half an inch deep. When the plants are 2 or 3 inches high, thin out to 4 inches apart. One ounce will sow 100 feet of drill.

CHAMPION MOSS CURLED. Beautifully curled leaves, deep, rich green. Pkt. $10 \mathrm{c}$; oz. $20 \mathrm{c}$; $1 / 4 \mathrm{lb} .60 \mathrm{c}$; lb. $\$ 1.75$.

\section{PARSNIP}

\section{Chirivia-Pantinake-Panais}

Culture. Sow from September to May, in deep, rick soll, in drills 15 inches apart, and cover the seed about half an Inch deep. When the plants are 2 or 3 inches hIgh, thin out to about 5 inches a part in the rows. One ounce of seed will sow 100 feet of row, or 5 pounds to one acre.

HOLLOW CROWN. The standard sort. Pkt. 10c; oz. $20 \mathrm{c} ; 1 / 4$ lb. $60 \mathrm{c} ; 1 \mathrm{~b} . \$ 1.75$.

\section{PEAS}

\section{Chlcharo: o Gutganter-Erbsen-Pols}

Culture. May be sown the year round in Callfornia. They will grow in almost any soil. but a deep, rich loam is best for main crop; the early varletles for winter will do best on a light, warm soil. deep plowing of the ground is essential. They are sown in single or double rows trum elghteen inches to 1 feet apart, according to the helght of the variety The tall sorts shnuld have sticks to climb over. For the feld crnp it garden, plant one pound to 50 feet of row.

\section{FIRST EARIY VARIETTES}

AMERICAN WUNDER, Extra early, dwarl, compact grower, wrinkled peas of the finest quality. Helght 1 foot. Pkt. $10 \mathrm{c} ; 1 / 2$ lb. 20c; 1b. 35c.

PREMIUM GEM. A popular early dware wrinkled variety. It grows about 18 Inches high and bears a heavy crop of good-sized pods filled with 6 to 8 peas of the finest quality. Pkt. 10c; $1 / 21 \mathrm{~b}, 20 \mathrm{c} ; 1 \mathrm{~b}$. $35 \mathrm{c}$.

GRADUS, OR PROSPERITY. The finest early pea yet introduced. Almost as early as American Wonder but grows about $2 \%$ feet hlgh and produces very long $10 \mathrm{c} ; 1 / 2 \mathrm{lb} .20 \mathrm{c} ; 1 \mathrm{~b}$. $35 \mathrm{c}$.

\section{SECOND EARLY VARIETIES}

ADMIRAL OR SENATOL. A new sort Introduced on our local market about three years ago. It is a good second early pea. has thick green foliage, and ears abundantly. Pkt. 10c; $1 / 2$ lb. 20c; 1b. $35 \mathrm{c}$.

STRATAGEM. One of the best peas in cultivation;

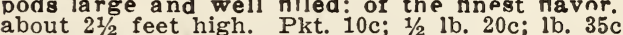

YORKSHIRE HERO. The popular market varlety in this locality. Grows about $2 \% / 2$ feet high. is ne fine quality and a good bearer. Pkt. $10 \mathrm{c} ; 1 / 2 \mathrm{lb}$. 20c; $1 \mathrm{~b}$. $35 \mathrm{c}$.

\section{LATE VARIETIES}

ALDERMAN. Of recent introduction; grows about 5 feet high: pods dark green always well flled with large peas of the finest quality. Pkt. 10c; 1. 1b. 20c; lb. $35 \mathrm{c}$.

TELEPHONE. A late variety; grows 5 leet hlgh,

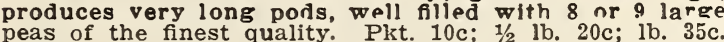

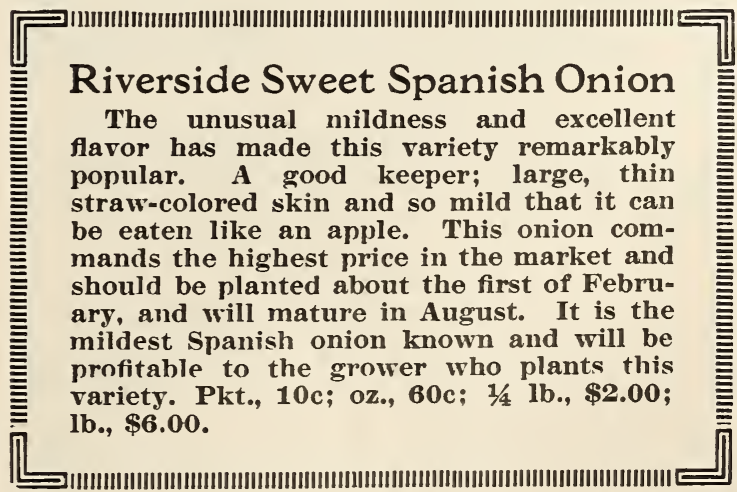




\section{PEPPER}

\section{Pimiento-Prefier-Piment}

Culture. Can be sown from the middle of January to the end of June. Sow the seed in boxes of light, rich soll, and keep in a frame or on a hot bed. When the plants are large enough, gradually harden off, and the plants are large enough, gradually harden off, and plant out in the open ground as soon as the weather has become warm and settled, placing the plants in rows 2 feet apart and $11 / 2$ leet apart in the row.

ANAHEIM CHILI. In great demand locally; similar to the Iexi chili, but larger. Pkt. 10c, oz. $50 \mathrm{c}, 1 / \mathrm{s}$. $\$ 1.65,1 \mathrm{~b}$. $\$ 5.00$.

CHINESE GIANT. Of very large size, averaging 10 to 15 inches in circumference. One of the best for stuffing; flesh thick, tender and mild. Pkt. 10c, oz. $\$ 1.20$; $1 / 4$ lb. $\$ 4.00$; lb. $\$ 12.00$

LARGE BELL, OR BULL NOSE. Large, early and Very productive Flesh thick and mild much used for stuffing. Pkt. $10 \mathrm{c}, 0 \mathrm{z} .80 \mathrm{c}, 1 / 4 \mathrm{lb}$. $\$ 2.65,1 \mathrm{~b} . \$ 8.00$.

PIMIENTO. One of the finest peppers of mild flavor that has yet been grown. It lends itself to a variety of uses, on account of its beauty, flrmness and attractive shape. It makes an unusually pretty salad, being smooth and bright in color, and it can be either canned or stuffed most satisfactorily, as it is flrm and fleshy. Plo $10 \mathrm{c}, 0 \mathrm{z}, 60 \mathrm{c}, 1 / 4 \mathrm{lb} . \$ 2.00,1 \mathrm{~b} . \$ 6.00$

\section{POTATOES}

Patatas-Kartofieln-Ponme de Terre

Culture. Potatoes succeed best in a good, rich, welldrained, sandy loam, and may be planted any time irom August to May. It requires about 400 pounds of seed potatoes to the acre.

EARLY ROSE, WHITE ROSE, TRIUMPH OR SIX WEEKS AND BURBANK. Prices on application.

\section{PUMPKIN}

\section{Calabaza-Kuerbis-Courge}

Calture. Sow from April to July in hills 8 feet apart each way and 3 or 4 seeds to a hill. One ounce will sow about $20 \mathrm{~h} 11 \mathrm{ls}$, or 2 pounds to one acre.

CHEEsE. Large, reddish orange flesh thick and sweet; good keeper. Pkt. $10 \mathrm{c}, 0 \mathrm{z}, 20 \mathrm{c}, 1 / 4 \mathrm{lb} .35 \mathrm{c}, 1 \mathrm{~b} . \$ 1.00$.

MAMMOTH TOURS, OR JUMBO. (King of Mammoths.) Grows to an immense size, often welghing 150 pounds or more. Skin orange-salmon, flesh bright yellow, fine grained, tender and sweet. Valuable for pies, also for

QUAKER PIE. Of medium size, slightly oval, skin rich creamy buff, flesh fine grained and of rich flavor.
A good keeper. Pkt. $10 \mathrm{c}, 0 \mathrm{z} .20 \mathrm{c}, 1 / 4 \mathrm{lb} 50 \mathrm{c}, 1 \mathrm{~b}$. $\$ 1.50$.

\section{FIELD PUMPKIN}

CALIFORNIA FIELD. The well-known Field Pumpkin so largely grown for stock. Varies in color from yellow, orange. red to drab. Very large and a heavy bearer. Pkt $10 \mathrm{c}, 0 z, 20 \mathrm{c}, 1 / 41 \mathrm{~b}, 45 \mathrm{c}, 1 \mathrm{~b} . \$ 1.25$.

LARGE SWEET FIELD. Very large, a favorite variety in this section, heavy yielder and good for stock feeding or for pies. Pkt. $10 \mathrm{c}, 0 \mathrm{z} .20 \mathrm{c}, 1 / 4 \mathrm{bb} .4 \mathrm{c}$ lb. $\$ 1.25$.

\section{RHUBARB_PIE PLANT \\ Ruibarbo-Rhabarber-Rhubarbe}

Culture. Sow from February to end of April in drills 18 inches apart, covering the seed about 1 inch deep. When large enough, thin out to 6 inches apart in the rows. Transplant the roots the following winter or rows. Transplant the roots the following winter or spring to deep, rich, well mart

WAGNER'S GIANT CRIMSON WINTER. A superior variety, producing stems twice as large as those of the ordinary Crimson Winter, and has been known to yield as high as 20 tons to the acre. It is unsurpassed in flavor, and is now in great demand on the local market. Pkt. $10 \mathrm{c}, 0 \mathrm{z} . \$ 1.60$, 1/4 1b. $\$ 5.00$

\section{SALSIFY}

Ontion Vegetal-Haferwurzel-Salsifis

Culture. Sow irom February to May, in deep, rich soll, in drills 15 inches apart. When large enough, thin out to 5 inches apart in the rows. One ounce of seed sow 50 feet of row.

MAMMOTH SANDWICH ISLAND. Verv large roots, tender and of rich flavor. Pkt. $10 \mathrm{c} ; 0 \mathrm{z} .25 \mathrm{c} ; 1 / 41 \mathrm{~b} .85 \mathrm{c}$;

\section{RADISH}

\section{Rabano-Rettig-Radis}

Culture. May be sown the year round in California. They can be grown in any good garden soll, but thrive best in a light loam enriched with plenty of good rotten manure. Sow in drills 12 inches apart. One ounce of seed will sow 100 feet of drill.

CALIFORNIA MAMMOTH WHITE. A large, pure white radish, often 9 to 10 inches long and $11 / 2$ to inches in diameter: flesh sweet, solid and crisp. Pkt. $10 \mathrm{c} ;$ oz. $20 \mathrm{c} ; 1 / 4$ lb. $50 \mathrm{c} ; 1 \mathrm{~b} . \$ 1.50$.

CHARTIER. A long variety and very attractive. The color is a rosy scarlet, shading to white at the tip. It is larger than the Long Scarlet, and keeps hard and crisp for a long time. Pkt. $10 \mathrm{c} ; 0 \mathrm{oz} 20 \mathrm{c}$; $1 / 4 \mathrm{lb} .50 \mathrm{c}$; 1b. $\$ 1.50$.

CRIMSON GIANT TURNIP. A new variety, more than twice the size of the Scarlet Turnip. It matures early, flesh white, crisp and solid. Pkt. 10c; oz. 20c; 1/4 1b. $50 \mathrm{c}, 1 \mathrm{~b} . \$ 1.50$.

EARLY LONG SCARLET SHORT TOP. An Old standard variety; grows to about 6 inches long; color bright carmine; flesh firm and brittle: ha very gmall top. Pkt. $10 \mathrm{c}$; oz. 20c; $1 / 4$ lb. $50 \mathrm{c} ; 1 \mathrm{~b}$. $\$ 1.50$.

FRENCH BREAKFAST. A popular early variety and one of the best for forcing. Grows about 2 inches long and stump rooted. The top part of the root is bright rose and the lower part white Pkt. 10c: $0 \mathrm{z}$. $1 / 4$ 1b. $50 \mathrm{c}, 1 \mathrm{~b} . \$ 1.50$.

ICICLE. A white variety; grows about 5 inches long, very brittle and of mild flavor. Pkt. 10c; oz. 20c; $1 / 4$ 1b. $50 \mathrm{c}, 1 \mathrm{~b} . \$ 1.50$.

LONG BLACK SPANISH. A large winter radigh, skin almost black; flesh white and solid. Pkt. $10 \mathrm{c}$, 20c; $1 / 4$ lb. $50 \mathrm{c}$; $1 \mathrm{~b}$. $\$ 1.50$.

ROUND BLACK SPANISH. Similar to the preceding, except in shape. Pkt. 10c; oz. 20c; 1/4 lb. 50c; lb. $\$ 1.50$.

SCARLET TURNIP. A very popular early sort. Roots scarlet, turnip-shaped, crisp and of good flavor. Pkt. 10c; oz. 20c; $1 / 4$ lb. 50c; ib. $\$ 1.50$.

SCARLET TURNIP WHITE TIPPED. Bright rosy carmine with lower part of root white: very attraccarmine, with lower part of root white; a very attr.
tive variety. Pkt. 10c; oz. 20c; $1 / 4$ lb. 50c; lb. $\$ 1.50$.

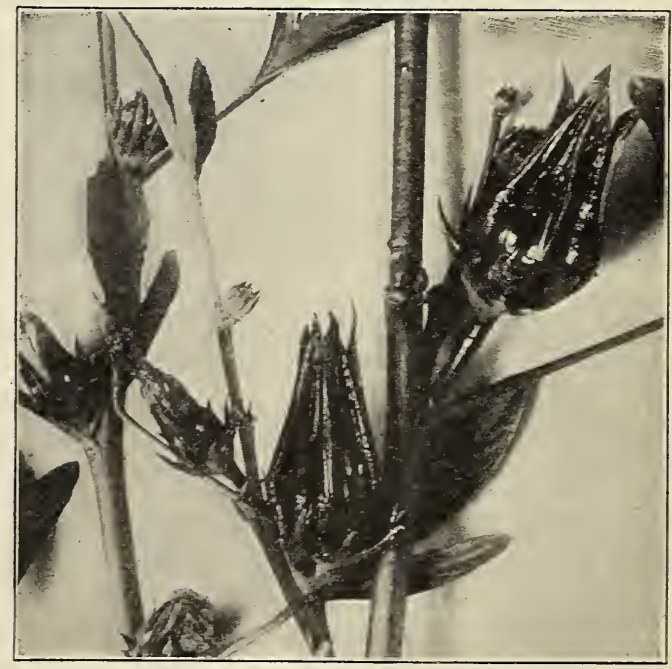

Roselle

\section{ROSELLE}

(Hibigcus subdorifa)

Culture. An annual plant, native of India, but introduced here from Queensland, Australia, where it is largely grown for making jelly. The plants grow from 3 to 6 feet high, and bear quantities of fruit, each enclosed in a thick, fleshy calyx, from which the jelly is made, which is considered by many superior to guava jelly. The seed should be sown in boxes or seed pans in February or March, and placed on a hot bed. The young plants can be potted up as soon as large enough. and when the weather is warm and settled they should be planted out in the open ground about 3 feet apart each way. Pkt. $10 \mathrm{c}, 0 \mathrm{z} .75 \mathrm{c}, 1 / \mathrm{k}$ lb. $\$ 2.50$. 


\section{SORREL}

Acedara-Sauerampfer-Osellle

Culture. Sow in spring, in drills 15 inhees apart, in any good garden soll. The plant is perennial, and can ae taken up every few years and divided. The flower bems should be kept cut off as they appear. The leaves are cooked like spinach, and are also used in soups.

LARGE LEAVED FRENCH. Pkt. 10c, oz. 25c, 1/4 lb. $85 \mathrm{c}, 1 \mathrm{~b}, \$ 2.50$.

\section{SPINACH}

Espinaca-Spinat-Epinard

Culture. Can be sown the year round in Callfornia, in drills 15 inches apart. One ounce of seed will sow 50 feet of row, or 12 pounds to one acre.

NEW ZEALAND. Produces large leaves. of thick, fleshy texture. Pkt. 10c; oz. 20c; 1/4 lb. 50c; 1b. $\$ 1.50$.

PRICKLY OR WINTER. The hardiest variety and the one generally grown for market. Large, smootb leaves shaped like

$1 / 4$ 1b. 20c, 1b. 60c. VIROFLAY. Exceedingly tender and delicious
lavor. Large smooth leaves. One of the best for commercial or home use. Pkt. 10c, 1/4 lb. 20, lb. 60c.

\section{SQUASH}

\section{Calabacera-Kuerbis-Courge}

Culture. As soon as the weather has become warm and settled, commence sowing for the early crop. The summer varieties mature much quicker than the winter varleties, and sowing for late crop may be continued until the first of August. Sow in hills 4 to deet rees plants. One ounce of thin out to the thre 40 hills, or 3 pounds to 1 acre. seed will The winter varietlout the later plantings should 8 to 10 feet apart, using 3 seed of July. Sow in hills 8 to 10 feet apart, using 3 seeds to a hill. One ou

\section{SUMMER VARIETIES}

BANANA. Grows from one to two feet long. Skin varies from bright yellow to olive green. Excellen quality, very sweet. Pkt. 10c; oz. $20 \mathrm{c} ; 1 / 4 \mathrm{lb}$. 50c; lb. $\$ 1.50$

GARLY WHITE BUSH SCALLOPED. Very early, creamy white, flat and scalloped; 4 to 6 inches in diameter exceedingly prolific. Pkt. $10 \mathrm{c}$, oz, $20 \mathrm{c}, 1 / 4 \mathrm{lb} .45 \mathrm{c}$ Ib. $\$ 1.25$.

ENGLISH VEGETABLE MARROW. Large, oblong, palom 12 to 18 inches long. Makes pale green, grows from 12 to 18 inches long. Pkt. $10 \mathrm{c}, 0 \mathrm{z}$. $20 \mathrm{c}, 1 / 4 \mathrm{~b}$. $60 \mathrm{c}, 1 \mathrm{~b}$. $\$ 1.75$.

ITALIAN OR ZUCCHINI. A bush squash of great merit; rich creamy flavor, and high in vitamines: bears heavily. Pkt. $10 \mathrm{c}$; 0z. $20 \mathrm{c}$; $1 / 4 \mathrm{lb}$. $65 \mathrm{c}$; $1 \mathrm{~b}$. $\$ 2.00$.

SUMMER CROOK-NECK. Long, with crooked neck right golden yellow thickly warted; very rich flavor. Pkt. 10c, oz. 20c, 1/4 lb. 50c, lb. $\$ 1.50$.

\section{WINTER VARIETIES}

HUBBARD. The popular winter squash. Oblong and pointed, dark green, heavily warted. Flesh orangecolored; a splendid keeper. Pkt. 10c, oz. 20c, 1/4 lb. 50c lb. $\$ 1.50$.

\section{TURNIP}

\section{Yabo-Rnebe-Naret}

Culture. Sow from October to May, in drills 16 inches apart, covering the seed lightly. When the plants are large enough, thin out to 5 or 6 inches apart in the rows. To grow good turnips it requires rich soll and plenty of moisture; this insures a quick, uninterrupted growth, and the turnips will be tender, and not woody as when slowly grown on poor soil. One ounce of seed will sow 100 feet of drill, or 2 pounds to one acre.

EARLY SNOWBALL. A pure white, globe-shaped varlety of extra fine quallty. One of the best for shipping. Pkt. $10 \mathrm{c}$, oz. $20 \mathrm{c}, 1 / 4$ lb. $40 \mathrm{c}, \mathrm{lb}, \$ 1.25$.

PURPLE-TOP STRAP-LEAF. The standard varlety for market or the home garden. Of medium size, flat, white, purple above ground, fine-grained and sweet. Pkt. 10c, oz. 20c, $1 / 4$ lb. 40c, 1b. $\$ 1.25$.

PURPLE-TOP WHITE GLOBE. Large, globe shaped. flesh white and sweet. An excellent variety and the best summer sort. Pkt. $10 \mathrm{c}, 0 z .20 \mathrm{c}, 1 / 4 \mathrm{lb}, 40 \mathrm{c}, 1 \mathrm{~b}$. $\$ 1.25$. IMPROVED PURPLE-TOP SWEDE OR RUTA BAGA. Very hardy, large, flesh yellow and solid. Üsed for cooking, also for feeding stock. Pkt. 10c, oz. 20c, 1/4 lb. $40 \mathrm{c}, 1 \mathrm{~b}$. $\$ 1.25$.

\section{TOMATO}

Gitomate-Liebemapfel-Tomate

Calture. Seed can be sown from January to May. The early sowing should be in seed boxes in frames or on a hot bed. When the plants are about 2 inches high they should be transplanted to shallow boxes, placing them should be transplanted to shallow boxes, placing them about 1 inch apart each way. Protect rrom cold, and Wanger from frost is over transplant to the open danger lrom trost is over, transplant to the open ground, placing them from Later sowings can be made in the open ground, in seed beds or drills, after danger from cold is past. In frostess localities where winter tomatoes are grown, the seed can be sown from the middle of August to the end of September. One ounce of seed should produce about 2000 plants.

PONDEROSA, OR BEEFSTEAK. A favorite sort for the home garden; of immense size, sometimes welgh. ing from two to three pounds each; very few seeds. Pkt. $10 \mathrm{c}$, oz. $70 \mathrm{c}$; $1 / 4$ 1b. $\$ 2.35$, 1b. $\$ 7.00$.

SAN JOSE CANNER. A fine smooth tomato for main crop, largely used for canning by reason of its tremendous yield of large tomatoes of irregular size. Pkt. $10 \mathrm{c}$; oz. $75 \mathrm{c}$; $1 / 4$ lb. $\$ 2.50$; $1 \mathrm{~b}$. $\$ 7.50$.

SPARK'S EARLIANA. Extra early, deep scarlet, large, smooth, solid and of the finest quality. The earliest large tomato grown. Fruit in clusters of flve to eight; average size $21 / 2$ inches in diameter. Pkt. $10 \mathrm{c}$ : oz. $50 \mathrm{c} ; 1 / 4 \mathrm{lb}$. $\$ 1.65$; lb. $\$ 5.00$.

STONE. A favorite sort for general crop, shipping and canning. Large, smooth, bright scarlet. very solid and a good bearer. Pkt. 10c, oz. 50c, $1 / 4 \mathrm{lb}$. $\$ 1.75, \mathrm{lb}$. $\$ 5.00$.

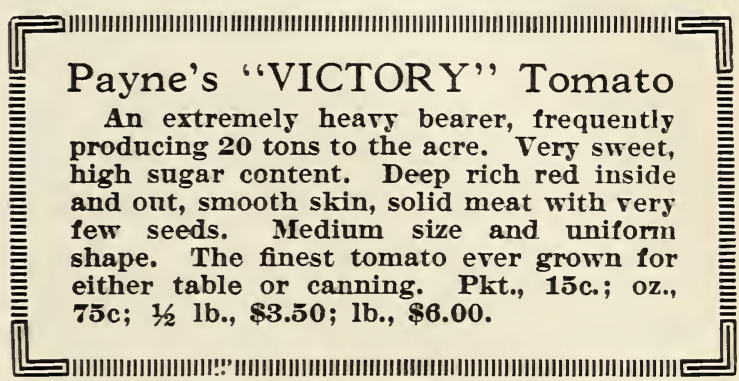

\section{WATER CRESS}

Berro-Brunnenkresse-Cresson de fontaine

Culture, Sow the seed by the side of running water or in a damp place. Pkt. $10 \mathrm{c}, 0 \mathrm{z} .60 \mathrm{c}, 1 / 4 \mathrm{lb} . \$ 2.00$.

\section{HERBS}

Per pkt. $10 c$

$\begin{array}{lll}\text { Anise } & \text { Coriander } & \text { Fennel, Sweet } \\ \text { Basil, Sweet } & \text { Cumin } & \text { Marjoram, Sweet } \\ \text { Borage } & \text { Dill } & \text { Rosemary } \\ \text { Caraway } & \text { Lavender } & \text { Savory, Summer } \\ \text { Catnip } & \text { Sage } & \text { Savory, Winter } \\ & \text { Thyme, Broad Leaved }\end{array}$

\section{Vegetable Plants and Roots}

We can supply plants or roots of Artichoke, Cabbage, Cauliflower, Chives, Egg Plant, Horseradish, Peppers, Rhubarb, Sweet Potatoes and Tomatoes at either of our stores during their seasons but do not advise nor guarantee satisfaction when sent by mail Prices upon application.

\section{Field and Fodder Crops}

ALFALFA, HAIRY PERUVIAN. This is considered to be a superior variety to the one generally grown here. It withstands more drought and cold weather, and in addition to this yields a larger amount of
foliage of a finer texture. Lb. $40 \mathrm{c}, 10 \mathrm{lbs}$. $\$ 3.50$, postpaid. Larger quantities, price on application.

ALFILERILLA OR FILAREE. (Erodium moschatum.) A native fodder plant, very nutritious and preferred by cattle, sheep and horses to any other of the fer ing on stock ranges where the natural pasture has ing on stock ranges where the natural pasture has $10 \mathrm{bs}$.

We have in stock a full line of Farm and Cover Crop seeds. Write for information and prices. 


\section{Tree and Shrub Seeds}

Where not otherwise stated all trees and shrubs described in this list are evergreen. Where a neight is mentioned it is understood that it is the ultimate height they attain. Space will not permit giving full instructions for sowing seed of each kind of tree but a few general remarks may not be out of place. Most tree seeds are better sown in the latter part of winter or spring, though there are many that can be sown at any time, and some which must be sown while the seeds are quite fresh. Most kinds are best sown in boxes, of light, well-drained soil, covering the seed about its own depth or some of the larger ones a little deeper, press the soll down slightly with the hands. Keep in a lath house, trame, or some sheltered place and water carefully. As soon as large enough to handle, pot and grow on until large enough to plant in the open ground, where they are to remain. Pines and other Conifer seeds are best sown in March and April; use a soll containing plenty of decomposed granite and always water in the morning and not at night, as the young seedings "damp off" very easily. Acacia seeds should be soaked in hot water for twelve hours or more before sowing. Some seeds are good only for a short time and in these cases I have stated the time at which fresb seeds can be had.

ACACIA ARMATA. "Kangaroo Thorn." 10 feet. A spreading shrub, with small yellow flowers, excellent for grouping and also for hedges. Pkt., 15c; oz., 75c; lb., $\$ 7.50$.

A. BAILEYANA. 30 feet. A strikingly beautiful tree with glaucous pinnate follage and covered late in winter with canary-yellow flowers which completely winter with canary-yellow flowers which compl
envelop the tree. Pkt., 15c; oz., 50c; 1b., $\$ 5.00$.

A. CULTriformis. "Knife-leaved Acacia." $8 \mathrm{feet.} \mathrm{A}$ pretty shrub, with triangular shaped leaves of a racemes. Pkt., 15c; oz., 50c; lb., $\$ 5.00$.

A. CYANOPHYLLA. "Blue-leaved Wattle." 25 feet. Leaves very large, often one foot long, glaucous green, branches drooping, flowers yellow. A beauthe sea coast. Pkt., 15c; oz., 50c; 1b., $\$ 5.00$.

A. CYCLOPS. 15 feet. A rather thick growing shrub of spreading habit, bearing quantities of rich, yellow flowers. It thrives particularly well near the coast, and on account of 1 ts dense habit, bright green foliage and yellow flowers, it is extremely ornamental, especially for planting in groups. Pkt., 15c; oz., $60 \mathrm{c}$; lb., $\$ 6.00$.

A. DEA LBATA. "Silver Wattle." 60 leet. A magnificent, rapld-growing tree with glaucous, finely cut follage and covered late in winter with golden. vollow flowers. One of the best for street planting. vellow flowers. One of the
Pkt., 15c; oz., 50c; 1b., $\$ 5.00$.

A. DECURRENS. "Green Wattle." 75 feet. A rapidgrowing tree and one of the best for avenues. Finely cut, feathery, light green follage. Flowers bright the bark is rich in tannin. Pkt., 15c; oz., 50c; lb., $\$ 5.00$.

A. ElATA. (A procera.) 60 leet. A very ornamental, rapid-growing tree, with large, handsome, pinnate ers. Pkt., 15c; oz., $\$ 1.00$.

A. Floribunda. (A. nerifolla.) 30 feet. A very quick growing species of pendulous habit, long narrow leaves; flowers light yellow. Pkt., 15c; oz., 50c; lb., $\$ 5.00$

A. JULibrissin. (Albizzia julibrissin.) 40 feet. A beautiful deciduous tree of widely spreading habit produced in large clusters, very showy. Pkt., 10c; prod, $50 \mathrm{c}$.

A. LATIFolia. See A. longifolla.

A. LIN IF OLIA. "Flax-leaved." 12 feet. A tall-growIng shrub, with long, narrow leaves; yellow fiowers in axillary racemes; very pretty for planting in groups. Pkt., 15c; oz., 60c; $1 \mathrm{~b} ., \$ 6.00$.

A. LONGIFOLIA. "Sydney Golden Wattle." 30 reet. Generally known in California, though wrongly, under the name of A. latifolia. Of rather slender habit. If properly trimmed it makes a fine street tree; also does well near the ocean; leaves long, lanceolate, glossy green. Very free fiowering. Catkins of light $0 \mathrm{z}$. 50c: $1 \mathrm{~b} ., \$ 5.00$.

A. Lophantha. (Alblzzia lophantha.) 30 feet. Of rapid growth and useful for temporary shelter; valuable for planting on sand dunes along the sea coast. Pkt., 10c; oz., 20c; 1b., $\$ 2.00$.

1. MELANoXYLON. "Blackwood." 75 feet. Of compact, pyramidal growth. The favorite tree for street pact, pyramial growth. The favorite tree for street planting in Los Angeles. The wood takes a beautiful polish and is considered almost equal to walnut. It is used in Australla for pi
Pkt., 15c; oz. 50c; 1b., $\$ 5.00$.

A. MOLLISSIMA. "Black Wattle." 50 feet. A rapid growing tree of erect and upright growth, with dark late spring. Pkt., $15 \mathrm{c}$; oz., $60 \mathrm{c} ; 1 \mathrm{~b}$., $\$ 6.00$.
A. PENDULA. "Weeping Myall." A rare and beautiful tree, with weeping branches, narrow, silvery oz., $\$ 1.50$.

A. PODALYRIAEF OLIA. A very rare and beautiful shrub, somewhat siimlar to A. cultriformis, but with larger leaves and larger flowers, which are produced in immense quantities early in winter and for this reason it is especially recommended for cutting. reason it is especially recommended for cutting.
Flowers rich canary yellow. Pkt., 25c; oz., $\$ 1.50$.

A. PRA VISSIMA. 20 feet. Large shrub of upright growth, but with very long, drooping branches. green. Flowers soft yellow, appearing in February and March. Pkt., 25c; oz.. \$1.50.

A. Prominens. 40 feet. One of the most beautiful of Acacias; of somewhat pendulous habit with small narrow foliage and great profusion of golden yellow flowers. Pkt., 25c; oz., $\$ 1.50$.

A. PRUIN OSA. 25 feet. A very beautiful tree with large, handsome, finely-cut foliage, which is of 8 ing of a soft rose color; flowers pale yellow. Pkt. $15 \mathrm{c}$; oz., $75 \mathrm{c} ; 1 \mathrm{~b} ., \$ 7.50$.

A. PYCNANTHA. "Golden Wattle." 30 feet. Of quick growth; leaves long and very broad; flowers in pendulous clusters, bright golden yellow and fragrant. Pkt., 15c; oz., 50c; 1b., \$5.00.

A. SAI.IGNA. 25 feet. Of drooping habit; leaves long, flowers rich yellow. Pkt., 15c; oz., 50c; 1b., $\$ 5.00$.

A. VERTICLLAATA. 12 feet. A shrub of rather spreading habit, with small linear leaves and with deep yellow and extending the entire length of the young branches; one of the best for planting in young branches; one of the
groups. Pkt., 15c; oz., $\$ 1.50$.

ACER MACROPHYLLUM. "Callfornia Maple." A declduous tree of great beauty, attaining a height of about 100 feet. Leaves large, deep, five-lobed, rich green, pale beneath. A native tree found growing along the sides of creeks in many of our canyons, but thriving under cultivation in the valleys. Pkt., $10 \mathrm{c}$; oz., $25 \mathrm{c}$; $1 \mathrm{~b}$., $\$ 2.50$.

ALBIZzIA. See Acacla.

AMPELOPSIS VEITCHII. "Boston Ivy." " Japan IVy." $A$ handsome deciduous creeper much used for covering stone, brick and wooden walls, to which it clings tightly. The leaves are shining, glossy green, turning red and yellow in the fall. Pkt., 10c; oz., $40 \mathrm{c}$; lib., $\$ 4.0$ r

ANGOPHORA LANCEOLATA. A tall spreading tree with clean, smooth bark, much resembling a eucalyptus, to which it is closely related. It is valuable for planting for ornamental purposes as single specimen trees. Pkt., 15c; oz. \$1.50.

ANONA CHERIM OLIA. "Cherimoyer." Peru. A small bushy tree with broad aromatic leaves. The fruits are produced in great abundance of a grayish-brown color, 3 to 5 inches in diameter, heart-shaped and
of a delicious flavor. Pkt. 15c; oz., 50c; lb., $\$ 5.00$.

ARBUTUS MENZIESII. "Madrone." 75 feet. A native tree found in the coast range. The foliage is thick, bright green and leathery; bark smooth, by red berries. Pkt., $15 \mathrm{c}$; oz., $50 \mathrm{c}$; lb., $\$ 5.00$.

A. UNEDO. "Strawberry Tree." South of Europe. 10 feet. Beautiful dark green follage. In the fall the trees are covered with both blossoms and fruit; the latter in appearance like strawberries. Pkt.o 15c; oz., $50 \mathrm{c} ; 1 \mathrm{~b} ., \$ 5.00$

ASH, ARIZONA. See Fraxinus.

BA UHINIA PURPUREA. 10 feet. A valuable shrub with dark-green, curiously bilobed leaves, and large. showy flowers. which are reddish-purple and white. Pkt. $15 \mathrm{c}$; oz. $\$ 1.50$. 
BERBERIS AQUIFOLIUM. "Oregon Grape." \& feet. A handsome shrub, with shining, purplish, prickly or nearly black berries. Pkt., 15c; 0z., 50c.

B. DARWINI. 3 feet A beautiful shrub with many slender branches, drooping towards the ends. The holly, and often turns a bright red in fall, which holly, and often turns a bright red in fall, which color it holds through the winter. In early spring the plants are covered with
yellow flowers. Pkt., $25 \mathrm{c}$.

B. JAPONICUM. 3 feet. Leaves about one foot long, bright yellow flowers, produced in terminal clusters. In hot, dry climates it should be planted in a shady situation. Pkt., $15 \mathrm{c}$; oz., 50c.

B. STENOPHYLLA. 4 feet. A very desirable shrub with long, slender, arching branches and small, long, narrow, dark green leaves, which are silvery on the underside. The flowers are golden yellow and produced in great profusion. Pkt. $25 \mathrm{c}$.

BROOM. See Spartium.

CALlistemoN RigidUs. "Bottle Brush." A beautiful shrub, with large red, brush-11ke flowers. Es. pecially valuable for dry places. Pkt., 15c; oz., \$1.50.

CALLITRIS ROBUSTA. "Cypress Pine." In Australia it grows to a Pair-sized tree, sometimes exceeding 90 feet in height, but the specimens in Southerm Callfornia have only attained the size of large shrubs. The branchlets are short, crowded and erect, giving the follage the appearance of growing
in tufts. It is very ornamental for planting in in tufts. It is very ornamental for planting in ance. Pkt., $25 \mathrm{c}$; oz., $\$ 1.50$.

CAMPHORA OFFICINALIS. "Camphor Tree." China and Japan. 40 feet. A very ornamental, symmetrical growing tree, with bright green, glossy follage, the young follage being of a pleasing delicate rose the young follage being of pleas for street plantcolor. Well adapted ror ing. The tree from which the camphor of commerce Pkt., 10c; oz., 30c; 1b., $\$ 3.00$.

CARPENTERIA CALIFOKNICA. A rare native shrub, with handsome, glossy follage, and fragrant, pure white flowers with yellow stamens. Pkt., 25c.

CASSIA ARTEMISIOIDES. Central Australia. A pret ty shrub, with finely cut sllvery gray follage and clear yellow, sweet-scented flowers; will stand any amount of drought. Pkt., $15 \mathrm{c} ;$ oz., $\$ 1.00$.

C. FLORIBUNDA GRANDIFLORA. 10 leet. Free blooming shrub, of rather loose, spreading habit. Leaves and stems smooth, deep green: flowers large, Leaves and stems smooth, deep green: flowers large,
yellow with brown anthers. Pkt.. 15c; oz.. $\$ 1.00$.

C. NAIROBENSIS. A handsome shrub of recent introduction. Of low spreading habit, large, rich green, pinnate leaves and immense trusses of large orangeyellow flowers. Pkt., $15 \mathrm{c}$; oz., $75 \mathrm{c}$.

C. TOMENTOSA. Mexico. A quick growing shrub with bright yellow flowers, blooming all through the winter. Very effective
$15 \mathrm{c} ;$ oz., $50 \mathrm{c} ; 1 \mathrm{~b} ., \$ 5.00$.

CASUARINA EQUISETIFoliA. "Beefwood." Southeast Australia. 50 feet. A striking tree of rapid growth, with drooping branches, dark green, needlelike leaves. Pkt. $15 \mathrm{c}$, oz. $\$ 1.00$.

C. QUADRIVALVIS. "Coast She Oak." Southeast Australia. 60 feet. Valuable for planting on the sea coast for holding the sand. Pkt. $15 \mathrm{c}$, oz $\$ 1.00$.

C. STRICTA. "She Oak." Attaining a height of about 75 feet. It forms a very handsome tree, is particularly valuable for planting along roadsides. It progh wood Pkt, 15c; 0z. $\$ 1.00$

CATALPA SPECIOSA. "Hardy Catalpa" 50 leet. A well known declduous tree of rapid growth, much in large panicles. Pkt., 10c; oz. $40 \mathrm{c}$; $1 \mathrm{~b}$. $\$ 4.00$.

CEDR US ATLANTICA. "Mt. Atlas Cedar." 100 feet. A splendid tree of upright, pyramidal growth with silvery green foliage. Pkt. 15c; oz. 60c, 1b. $\$ 6.00$.

C. DEODARA. "Himalayan Cedar."120 feet. One of the most handsome trees in cultivation, succeeding well in California Pkt. $15 \mathrm{c}$, oz $60 \mathrm{c}, 1 \mathrm{~b}$. $\$ 6.00$.

C. LIBANI. "Cedar of Lebanon." Of spreading habit, the whole top seeming to grow in "shelves," the branches growing horizontally; of darker green than
the preceding. Pkt. 15; oz., 60c, $1 \mathrm{~b}, \$ 6.00$.

CERATONIA SILIQUA. "St. John's Bread," or "Carob Tree." 40 feet. A thick-growing tree with masses of dark green follage: will grow in any soll and with scarcely any water. Pkt. 10c, oz, $25 \mathrm{c}, 1 \mathrm{~b}, \$ 2.50$.

CHAMAECYPARIS LAWSONIANA. "Lawson's Cy press." Callfornia and Oregon. 200 feet. One of the most striking and graceful of all evergreen trees. With horizontally spreading pendulous branches and flat. compressed follage: unsurpassed for specimens on lawns. Pkt. 15c, oz. 50c, 1b. \$\$5.00.
CHORIZEMA IWICWOLIUM. A spreading shrub or half-climber from Australia. The leaves are long With wavy margins and spine-like teeth, somewhat like holly. The flowers are small, pea-shaped; red, purple and yellow. It blossoms in winter and early liant colors. Pkt. $25 \mathrm{c}$.

COPROSMA BAUERI. A very handsome low growing shrub. The leaves are almost round, of a clean, glossy green color and have the appearance of having been varnished. It is especially valuable for planting in small beds, around a porch or against a
wall. Pkt. 15c, oz. $\$ 1.00$.

CORNUS CAPITATA. (Benthamia fragifera.) "Evergreen Dogwood." 15 feet. Large shrub with flowers resembling those of the Eastern Dogwood, creamcolored, changing to a reddish shade before falling. This shrub is better suited to Callornia conditions than the eastern species and has the advantage of being an evergreen. Pkt. $15 \mathrm{c}, 0 \mathrm{z} .50 \mathrm{c}, \mathrm{lb}$. $\$ 5.00$.

CORONILLA GLAUCA. A small shrub with glaucous foliage and quantities of bright yellow pea-shaped Pkt. $15 \mathrm{c}, 0 \mathrm{z}, 75 \mathrm{c}$

COTONEASTER PANOSA. A very desirable shrub, of spreading habit, with many gracefully drooping and winter with quantities of bright red berries. Pkt., 10c: oz., 40c; 1b., $\$ 4.00$.

C. FRATCheTI. A handsome shrub with many gracefully arching branches. Foliage of medium size, dislow berries. Pkt., 10c; oz., 40c; lb., $\$ 4.00$.

CRYPTOMERIA JAPONICA. “Japan Cedar." 120 feet. The largest tree of Japan, attaining 35 feet in circumference and ylelding a valuable timber. Very oz., $40 \mathrm{c}$; $1 \mathrm{~b}$., $\$ 4.00$.

O. ELEGANS. "Fine-leaved Japan Cedar." Very ornamental, fine feathery foliage, which in winter turns to a reddish brown. A splendid tree for planting on lawns. Pkt. 15c, oz. 50c.

CUPRESS US ARIzONICA. "Arizona Blue Cypress." 70 feet. A tree of great scenic value, and without doubt the most silvery of all the Cypresses. It grows quite rapidly, and forms a perfect tree, thriving in almost any soll, standing intense heat, and much frost. Pkt., 15c; oz., 50c; lb., $\$ 5.00$.

C. BENTHA Mi KNIGHTIANA. "Knight's Cypress." 70 leet. A remarkably handsome tree with drooping, feathery branchlets and glaucous follage. Pkt. 15c, oz., $60 \mathrm{c}$; $1 \mathrm{~b}$., $\$ 6.00$.

C. FUNEBRIS. "Weeping or Funeral Cypress." 60 leet. A tree with wide spreading, pendulous
branches and rich, green, graceful foliage. Pkt. 15c. oz., 60c: lb., $\$ 6.00$.

C. GOVEniAnA. "Govens Dwart Cypress." A native species of erect growth, forming a handsome crown: dark green foliage. Pkt., 15c; oz., $60 \mathrm{c}$; 1b., $\$ 6.00$.

C. MACROCARPA. "Monterey Cypress." 70 feet. A native tree, extensively planted for hedges and equally valuable for single speciments. The ree becomes very pict

C. LUSitANiCA. (C. glauca) "Blue Cypress." A rapld growing tree of rather spreading habit with glaucous follage. Pkt. $15 \mathrm{c}, 0 z .50 \mathrm{c}, 1 \mathrm{~b}$. $\$ 5.00$.

C. SEMPER VIRENS VAR, FASTIGIATA. "Itallan Cypress." 75 feet. A tall, tapering tree with erect branches, growing close an

CYDONIA JAPONICUM. "Flowering Quince." China and Japan. A beautiful declduous shrub, bearing early in the pring. Pkt. 15c, oz. \$1.00.

CYPHOMANDRA BETACEA. (Sola num betaceum.) "Tree Tomato" Grows to a helght of about 8 foet. with large, handsome follage. It produces quantities of egg-shaped fruits, which are of a bright orange color, and are sometimes used for preserves $P k t$. $25 \mathrm{c}$.

CYTISUS LABURNUM. "Golden Chain." A beautiful declduous tree, with pretty follage and long, pendulous panficles of pea-shaped flowers, of a rich yellow; appearing early in spring. Pkt. $15 \mathrm{c}$, oz. $50 \mathrm{c}$.

CYTIS US PROLIFER US. "Tagasaste." A shrub grow: ing to a height of about 12 feet. It produces large appearing early in spring. Pkt. $15 \mathrm{c}$ 0z., $75 \mathrm{c}$.

DENDROMECON RIGIDUM. "Tree Poppy." A native Derennial shrub 4 to 8 feet. Graceful, willow-like folle and bright-yellow flowers, 3 inches or more in diameter; blooms nearly all the year. Seed is hard to germinate. Pkt. $15 \mathrm{c}$.

ER YTHRINA CRISTA GALLI. “Coral Tree." Brazll. 30 feet. A beautiful deciduous tree, with large, deep flowers. Pkt., 15c; oz., $\$ 1.00$. 


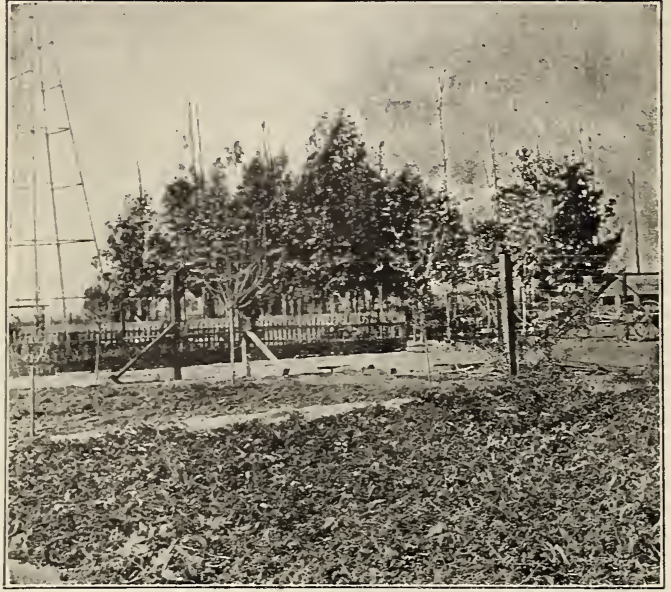

Eucalyptus seed vessels, spread out on canvas to dry

\section{Eucalyptus Seeds}

NOTE. We have for many years specialized in Eucalyptus seeds and carry the most complete stock on the Pacific Coast. Anyone interested in this type of trees will do well to send for our special pamphlet which gives detailed information on proper methods of propagation, adaptability to climatic conditions and the many uses to which this tree is ideally suited. Sent free upon request.

EUCALYPTUS AMYGDALINA. "Peppermint Gum." An exceedingly tall growing tree; in fact, to this species belong probably the tallest trees in the world. Baron Von Mueller having recorded trees over 400
feet high and with diameters of 18 to 35 feet. The feet high and with diameters of 18 to 35 feet. The heights mentioned being attained in moist ravines under less favorable conditions it forms a much smaller tree, and in some cases is comparatively dwarf. The timber is useful for shingles, flooring, etc., but does not usually last well under ground. One of the most valuable for oil, producing more volatile oil than any other species yet tested. Recommended for planting in swampy places as a preventative for yellow fever, etc. Pkt. 15c, oz. 75c ventative
lb. $\$ 7.50$.

E. AMYGDALINA, VAR, ANGUSTIFOLIA. See E. linearis.

E. BOSISTOANA. "Bairnsdale Grey Box." A tree of medium size, most suited to the coast sections, but has not yet been thoroughly tested in California. ough, Victoria, Australia, speaks of this tree as follows: "It produces a clean, sound wood, much esteemed for the construction of wharves, jetties and bridges. It grows to large dimensions. Trees are to be found in South Victoria containing 20,000 feet super of timber. It furnishes also good rallway sleepers and street paving blocks. grows naturally near the coast and is never found grows naturally near the coast
far inland." Pkt. 15c, oz. $\$ 1.50$.

F. Botr y OIDES. "Bastard Mahogany, or Bangalay." Grows to a fairly large size, reaching 75 to 150 feet when fully grown. Of stately appearance with large, leathery green follage; succeeds well near the coast and is of very rapid growth; one of the best for shade purposes and wind-breaks. The wood is very durable, adapted for wagon building, knees of boats, etc. Pkt. $15 \mathrm{c}, 0 z$. $75 \mathrm{c}, 1 \mathrm{~b}$. $\$ 7.50$.

G. CA LOPHYLLA. A moderate sized tree, thriving in warm, moist situations near the coast, but not enof the genus, has very large, glossy leaves and large of the genus, has very large, glossy leaves and large clusters of white flowers which are valuable for
bees. The wood is useful for rafters, spokes, fence rails, handles of agricultural implements, etc.; on of the very best for planting as a street tree. Pkt. $15 \mathrm{c}, 0 \mathrm{z} . \$ 1.00$.

F. CAPITELLATA. "Mountain Stringy-bark." A large tree with rough, stringy bark, and thick, leathery
leaves. It is best adapted to cool, moist land near the coast. It is said to furnish a valuable lumber. but in California it has only been grown as an ornamental species. Pkt. 15c, oz. \$1.00.
E. CITRIODORA. "Lemon-scented Gum." A fastgrowing species soon becoming tall and slender. In favorable situations it has attained $a$ height of 60 to 100 feet in 10 or 15 years. It thrives best near the coast, but will not endure much frost and is not adapted to the warm, interior valleys. The wood is strong and durable, useful for fencing, implement handles, shipbuilding, paving, railway ties, of houses, carriage bulldings and rallway cars. Pkt. $15 \mathrm{c}, 0 \mathrm{z}$. $\$ 1.50$.

E. CORNUTA. "Yate Tree." A medium size tree of fairly rapid growth. It endures high temperatures, but not heavy frosts; thrives well near the coast and will endure the hot summers of the interior valleys. Grows remarkably well in alkali land. One of the best for shade trees. The wood is very hard of the best for shade trees. The wood is very hard and heavy and according to tests of the Australian Government is the strongest wood in the world. It is used for various artisans' work and is prelerred for the strongest parts of carts, wagons and other work requiring hard
ticity. Pkt. $15 \mathrm{c}$, oz. $\$ 1.00$.

E. CORNUTA, VAR. LEHMANNI. A rather small tree with thick spreading branches and of great value for ornamental purposes. Pkt. 15c, oz. $\$ 1.00$.

E. CoRYNOCALYX. "Sugar Gum." 120 feet. This tree succeeds in a great variety of climates; thrives near the coast and does equally well in the interior and in the hot valleys of Arizona, but will not stand much frost. It is considered the most droughtresisting of all and is one of the best for planting on dry hillsides. The wood is one of the strongest and is very durable, useful for railway ties and underground work. Pkt. 15c, oz. $\$ 1.00$, 1b. $\$ 9.00$.

E. CREBRA. "Narrow-leaved Ironbark." 100 feet. It succeeds under a great variety of climatic conditions, withstanding great extremes of heat and cold. The wood is hard, elastic and of a reddish color; very durable under ground and used for railway ties, poles, piles, etc. Pkt. $15 \mathrm{c}, 0 \mathrm{z}$. $\$ 1.00$.

E. FICnFOLIA. "Scarlet-flowering Gum." 30 feet. A very ornamental specles with large, leathery leaves and immense clusters of large, bright crimson flowers. 25 seeds $25 \mathrm{c}, 100$ seeds $85 \mathrm{c}$.

E. GLOBULUS. "Blue Gum." The best known species and one of the most important of the genus, also the fastest growing of all. The usual height in Australia is 200 to 300 feet. In California trees 30 years old have attained the height of 150 feet and a diameter of 3 to 6 feet. It is usually of erect growth. succeeds best near the coast and on account of 1 ts rapid growth is probably the most profitable tree to plant. The wood is durable above ground; large to plant. The wood is durable above ground; large for felloes, poles, reaches and singletrees of wagons, for felloes, poles, reaches and singletrees of wagons, flooring, insular pins and anything requiring furniture and interior finishing. Pkt. $15 \mathrm{c}, \mathrm{oz} .75 \mathrm{c}$. Ib. $\$ 7.50$.

E. GONIOCALYX. "New South Wales Blue Gum." A large tree, reaching a height in Australia in favored situations of 300 feet. It succeeds well in Callfornia in the coast regions. The timber is hard and tough, used for wheelwrights' work and shipbuilding. Pkt. $15 \mathrm{c}$, oz. $\$ 1.00$.

E. GUNNI. "Tasmanian Cider Tree." This is one of the hardiest of the genus. In its native habitats it grows in low lands where it forms a fair sized tree and sometimes reaches 150 feet or more. It also ascends the mountains to an elevation of 5000 feet, but here becomes a dwarf tree or mere shrub. It is extremely hardy, growing where there is snow for several months in the year. Should prove one of the best for planting in our mountalns for forest cover. The wood is used for various artisans' work. Pkt. 15c, oz. $\$ 1.00$, 1b. $\$ 10.00$.

E. HeMiphlota. "Common Box." 100 to 150 feet. It thrives in California near the coast and also in the hot interior valleys, standing extremes of heat and cold. One of the best for shade purposes. The timber is strong, close grained and used for wheeltimber is strong, close grained and used for wheel-
wrights' work, piles, railway ties, posts, etc. Pkt. $15 \mathrm{c}, 0 \mathrm{z}$. $75 \mathrm{c}, \mathrm{lb}$. $\$ 7.50$.

E. LEUCOXYLON. "Victorian Ironbark." 100 feet. The trees are apt to grow crooked, but by giving them some attention when young they may be made them some attention when young they may be made grow straight. This species will grow in a greater variety of climates than most eucalyptus, thriving near the coast or in the hot desert valleys of the interior and will endure minimum temperatures of 15 degrees to 20 degrees $F$. It is one of durable, excelling hickory in strength; used for railway ties, mining purposes, wagon building, shlpbuilding, etc. Pkt. 15c, oz. $\$ 1.00$, lb. $\$ 10.00$. 
E. LEUCOXYLON, VAR. ROSEA. A variety of the preceding, having beautiful pink flowers, and of great value as an ornamental tree, and can be grown
in localities where $E$. ficifolia will not thrive. Pkt. $15 \mathrm{c}, 0 z$. $\$ 1.50$.

E. LINEARIS. An ornamental species of somewhat weeping habit, with small, very narrow leaves. It has been known in California, though wrongly, under the name of
Pkt. $15 \mathrm{c}, 0 z . \$ 2.00$.

E. LONGIFOLIA. "Woolly Butt." A moderate sized tree, but in Australia under favorable conditions has sometimes reached a height of 200 feet. In California it thrives best near the coast. The timber
is useful for posts, ties, street paving, etc. Pkt. $15 \mathrm{c}, 0 \mathrm{z} .75 \mathrm{c}$.

E. MACULATA. "Spotted Gum." Attains a height of 150 feet, growing remarkably straight. The wood is used for shipbuilding, wheelwrights' and coopers work. It is closely allied to E. citriodora and suc-
ceeds under the same conditions. Pkt, 15c, oz. $\$ 1.00$.

E. MELLIODORA. "Yellow Box." A fair sized tree, reaching a height of 120 to 150 feet. In California it thrives near the coast, on the sides of low mountains and in warm, dry interior valleys. The wood is hard and durable, used for wheelwrights' work, shipbuilding and supplies one of the best fuels. The shipbuilding and supplies one of the best fuels. The young trees have been used for telegraph poles. of the best as a source of honey for bees. Pkt. 15c, oz. $\$ 1.25$.

E. MUELLERIANA. "Yellow Stringy-bark." A tree of medium size, best suited to the coast region, but it has not been thoroughly tested in Callfornia. The wood is remarkably durable. Mr. J. Black"A fence erected of this timber at Greemount, near Yarram, in Gippsland, sixty years ago, is at the present time sound and in use. The posts of another one on the old Cascade run (Gippsland) are still in good order after being in the ground for seventy years." Pkt. $15 \mathrm{c}, 0 z . \$ 1.50$.

E. OBLIQUA. "Stringy-bark." A tall, straight-growing tree, sometimes attaining a height of 300 feet in Australia. In California it grows fairly well near the coast, but does better some distance inland; will not succeed, however, in the hot, dry interior will not succeed, however, in the hot, dry interior
valleys. The timber is straight and easily split, valleys. The timber is straight and easily split, ukt. $15 \mathrm{c}$, oz. $75 \mathrm{c}$.

E. PILULARIS. "Black Butt." In Australia under favorable conditions it has attained a helght of 300 feet, but the average height is 100 to 150 feet. In California it succeeds well near the coast, but will is strong and durable, useful for house bullding. shipbuilding, bridges, telegraph poles and railway ties. Pkt. $15 \mathrm{c}$, oz. $\$ 1.00,1 \mathrm{~b} . \$ 10.00$.

E. PIPERITA. "White Stringy-bark." A fair sized tree. It succeeds well near the coast and in cool inland situations. The timber is easily split and used for fencing and general bullding purposes. Pkt. $15 \mathrm{c}$, oz. $\$ 1.00$.

E. Polyanthema. "Red Box." In Australia this tree attains a height of 150 feet or more. In California it thrives under a great variety of climatic hills and mountains and in the hot, dry valleys of the interior. It is one of the most ornamental species; the leaves are nearly round and with a silvery lustre; the flowers are small, white, in large clusters and are a great source of honey. The wood is extremely hard and lasting, used for rallway ties. mining purposes and wheelwrights work. It is of a light color and takes a good polish. Pkt, 15c, oz. $75 \mathrm{c}, 1 \mathrm{~b} . \$ 8.00$

E. PUNCTAtA. "Leather-jacket." A medium sized tree attaining a height of 100 feet in Australia. In some fine specimens best near the coast, though The young trees at the to be seen in Riverside. The young trees at the Forestry Station at Santa Monica have made a rapid growth and grown remarkably straight. The wood is one of the strongest, of a light brown color, very hard and durable, poses. This species promises to be one of the best for planting commercially in situations near the coast. Pkt. $15 \mathrm{c}, 0 \mathrm{z} . \$ 1.00$, lb. $\$ 10.00$

E. RESINIFERA. "Red Mahogany." 100 feet or more This tree thrives in the coast regions and is sulted to moist, semi-tropical climates, but will not thrive in the hot interior valleys and will not resist severe
It has been said that this tree is of slow growth, but trees on the dry mesa near Santa Monica have made a growth that compares favorably with many of the foremost species. The wood is of a rich, red color, resembling true Mahogany; it takes a fine polish and makes the most beautiful furniture. and is used in Australia for piles, posts, paving and general building purposes. Pkt. 15c, oz. $\$ 1.00,1 \mathrm{~b}$. 0.00 .

E. ROBUSTA. "Swamp Mahogany." 100 feet. This tree thrives best in low, moist land, but has been grown under many varying conditions. It is symmetrical in growth when young and has been largely planted as a street tree and for wind-breaks. It has large, glossy foliage and white flowers which are valuable for bees. The wood is brittle and not very valuable, but is durable under ground. Pkt. $15 \mathrm{c}$, oz. $60 \mathrm{c}$, lb. $\$ 6.00$.

E. Rostrata. "Red Gum." In Australia it is said to attain a height of 200 feet under favorable conditions. It succeeds under a greater variety of conditions and soils than probably any other species, growing well on moist land near the coast and in the hot interior valleys, standing extremes of heat and cold. It has done remarkably well at Imperial and all other irrigated sections on the desert. When grown near the coast it is not of rapid growth, but in the hot interior sections it grows quickly, making about the same growth as the "Blue Gum" Will in the coast regions. This tree has been planted very extensively and is recognized as one of the best commercial species for the hot interior sections. The wood is strong and durable, useful for railway ties, piles, street paving, for cabinet work. Pkt. $15 \mathrm{c}$, oz. $50 \mathrm{c}, 1 \mathrm{~b} . \$ 5.00$.

E. RUDIS. 75 to 100 feet. One of the best for street planting. It stands extremes of heat and cold; thrives near the coast and has grown so well in irrigated sections on the desert that it has been termed by some "The Desert Gum." Pkt. 15c, oz.

E. SIDEROPHLOIA

"Broad-leaved Ironbark." 100 feet. This tree thrives in California, in the coast regions, but is not suited to the dry, hot interior valleys. The wood is very strong and durable, useful for wagon building, rallway ties, etc. Pkt. $15 \mathrm{c}$,
oz. $\$ 1.00$.

E. SIDEROXYLON. "Red Ironbark." A medium sized tree. In Californla it succeeds on dry soils near the coast and on plains and hillsides farther inland and will endure minimum temperatures of 16 degrees to 20 degrees $F$. The wood is of a dark red color, hard and heavy, useful for railway ties, bridges, wagon work, etc. Pkt. $15 \mathrm{c}$, oz. $\$ 1.00$.

E. SIDEROXYLON, VAR. ROSEA. A variety of the preceding, with deep pink flowers, which contrast well with the dense silvery gray foliage. By many eucalyptus. Pkt. $15 \mathrm{c}, 0 \mathrm{z}$. $\$ 1.50$.

E. STUARTIANA. "Apple-scented Gum." A medium sized tree. It thrives near the coast and will endure minimum temperatures of 10 degrees to 18 degrees F.; and can be planted at higher elevations than most species. The wood is mostly used for fence posts and for fuel; it is also useful for furing a good polish. Pkt. $15 \mathrm{c}, 0 z$. $\$ 1.00$.

E. TERETICORNIS. "Forest Red Gum." 150 feet. One of the very best for commercial use, closely allied to E. rostrata, but forming a straighter tree. For general timber purposes I belleve this is the best of the whole genus, taking all conditions and uses into consideration. It stands considerable heat and cold, thrives in sections near the coast, further inland in the hot interior valleys and in irrigated sections of the desert. Under the latter conditions it makes a remarkably rapid growth. This tree has been planted on a very la
nia. Pkt. $15 \mathrm{c}$, oz. $75 \mathrm{c}, 1 \mathrm{~b}, \$ 7.50$.

E. VIMINALIS. "Manna Gum." In Australia this tree has attained to a height of 300 feet with a diameter of 15 feet. It is an exceedingly handsome tree with long pendulous branches, and is one of the most with long pendulous branches, and is one of the will picturesque for avenue planting. This tree will thrive under a great variety of conditions, grow the near the coast, also in irrigated. It stands condeserts of California and Arizona. It stands considerable heat and cold and will thrive at a higher altitude than most of the other species. In the coastal regions it is of very rapid growth, being only rivaled in this respect by the "Blue Gum, by any other species. Pkt. $15 \mathrm{c}, \mathrm{oz}$. $75 \mathrm{c}$. 1b. $\$ 7.50$. 
FRAXIN US VELUTINA. "Arizona Agh." A dectduous tree, largely planted in Arizona and New Mexico for shade purposes, and is of great value, being of quick growth, and standing both heat and drought remarkably well. Pkt., 15c; oz., 50c.

TREMONTIA CALIFORNICA. "California Slippery Elm." A heautiful native shrub, growing from 5 to 20 feet high. It reaches its greatest perfection on the desert side of our mountains. The flowers are the dares seed is hard to germinate. Pkt. $15 \mathrm{c}$; oz., $\$ 2.00$.

GENISTA ANDREANA. A free flowering shrub. Flowers bright yellow, marked with crimson. Pkt. $15 \mathrm{c}$, oz. $\$ 1.00$

a. CANARIENSIS. A pretty shrub, very effective for planting in groups, being covered in spring with bright yellow flowers. Pkt. 15c, oz. 75c.

G. FRAGRANS. (G. ramosissima.) of rather compect growth, covered with bright yellow fragrant flowers. Often grown as a pot plant. Pkt. 15c, oz. $\$ 1.25$.

A. HONOSPERMA PENDULA. "Bridal Veil." 10 feet. $\triangle$ rare and handsome shrub with fine, drooping, silverv hranchlets. The flowers are white and produced in immense numbers. Pkt., $25 \mathrm{c}$; oz., $\$ 1.25$.

G. STENOPETALA. (G. maderensis.) A magnificent shrub with handsome trifoliate foliage and very long spikes of large, bright yellow flowers. Very ornamental and useful for cutting. Pkt. 15c, oz.
$\$ 1.25$.

GREVILLEA ROBUSTA. "Silky Oak." 150 feet. A large tree with pretty fern-like follage. covered late in spring with orange-colored flowers which are a great source of honey for bees; does well in all parts of Calfernia and is one of the most stately trees for avenue planting; thriving with scarcely any water. Pkt. $15 \mathrm{c}, 0 \mathrm{z}, 60 \mathrm{c}, 1 \mathrm{~b}, \$ 6.00$.

QUAva. See Psidium.

HAKEA LAURINA. ( $H$. eucalyptoides.) 10 feet. A winter blooming shrub, with foliage similar to the red flowers with white stigmas. Pkt., 25c.

E. PUGIONIFORMIS. Much branched shrub of spreadIng habit, having short, needle-like leaves and large numbers of white flowers. From a short distance it has the appearance of a dwart pine. It is of rapid growth and especially valuable for dry solls. This is the true $H$. pugioniformis and must not be confused with $H$. pectinata, a very different plant, but which has been known by many nurserymen under the former name. Plat. 25c.

E. SALIGNA. Of similar habit to H, laurina, but has narrower leaves and white flowers. Pkt. 25c.

B. SUAVEOLENS. (H. pectinata) A dense shrub attaining a height of 8 to 10 feet, with deeply cut charp-pointed leaves and white flowers. Pkt. 25c.

HETEROMFLES ARBUTIFOLIA. "Callfornia Holly" or "Christmas Berry." 10 teet. A native Californle shrub; found plentifully in all our foothllls. Very desirahle on account of its handsome toliage and also for its bright colored berries. Pkt., 10c; oz. $40 \mathrm{c}$; 1b., $\$ 4.00$.

JACARA NDA MIMOSAEFOLIA. (J. ovalifolla) Brazil. 30 feet. One of the finest of our flowering trees, literally covered in early summer with large blue bignonia-like flowers. The tollage is finely cut like a lern and very pretty. In pods containing from 30 to 40 seeds. Pod $5 \mathrm{c}$, doz. pods $50 \mathrm{c}$.

JUNIPER US CA LIFORNICA. "California Juniper." A native shrub or small tree of spreading hablt, found in dry washes. The follage is of a beautiful, derp, rich green. Pkt. $10 \mathrm{c}, 0 \mathrm{z}, 40 \mathrm{c}$. 1b. $\$ 4.00$.

J. BER Y UDIANA. "Bermuda Juniper." 40 feet. A beautiful tree of densely branched pyramidal form foliage of a pale bluish-green color. Pkt. 15c. oz.
$50 \mathrm{c}$.

J. COMMUNIS. "Common Juniper." 40 feet. A tree of upright, rather compact growth; beautiful grey green follage. Pkt. 10c, oz. $40 \mathrm{c}$.

J. SABINA VAR PROSTRATA "Dware Tralling Jun. Iper" A dwarf tralling variety. with handanmo glaucous foliage. Very valuable for rock garden. etc. Pkt. $15 \mathrm{c}, 0 \mathrm{z}$. $50 \mathrm{c}$.

J. VIRGINIANA. "Red Cedar." U. S. 100 feet. A well known tree with green or bronze green follage.
Pkt. $10 \mathrm{c}$. oz. $35 \mathrm{c}$, lb. $\$ 3.50$.
LAGUNARIA PATERSONI, 20 leet. A small pyramidal tree with ovate leaves, whitish underneath; flowers something like Hibiscus, pale rose color. Pkt. $15 \mathrm{c}, 0 \mathrm{z}$. $75 \mathrm{c}$.

\section{LAURESTINUS. See Viburnum.}

LAVATERA ASSURGENTIFLORA. Native of San Clemente Island. It forms a spreading shrub and is especially valuable for planting on sand dunes and banks to hold the soll, also used for planting ind banks to hold the soll, also used for planting in chicken yards for temporary

LEPTOSPERMUN LAEVIGATUM. This beautiful shrub does particularly well in California, and is very valuable for planting in masses and for flling up odd corners. It grows rapidly and in the spring is laden with a profusion of white blossoms. Pkt. $25 \mathrm{c}$, oz. $\$ 2.00$.

L. SCOPARIUM VAR. NICHOLLII. A rapid growing shrub with small purplish green foliage and quantities of carmine red flowers. Pkt., 25c.

CEUCA DEN DRON ARGENTEUM. "SHlver Tree." Cape of Good Hope. 30 feet. A rare tree, some fine specimens of which are to be seen in Santa Barbara. It has lanceolate, silvery leaves, densely covered with silky halrs. Great care must be taken to have good drainage in the seed pans or boxes as the young seedlings "damp" off very easily. 10 seeds 25c, 100 seeds $\$ 2.00$.

WBOCEDRUS DECURRENS. "Incense Cedar." 100 feet. A native California tree, thriving well under cultivation. It forms a very handsome, compact growing tree, with cinnamon red bark and bright green foliage, glaucous underneath. Pkt. 15c, oz. $60 \mathrm{c}, 1 \mathrm{~b} . \$ 6.00$.

MIGUSTR UM NEPALENSE. "Small-leaved Privet." 10 feet. Much used for hedges in Southern Call. fornia. It grows quickly and can be trimmed in any way desired. making a dense, thick hedge. Leaves Pkt. 10c, oz, 25c, 1b. $\$ 2.50$.

LIGUSTRUM JAPONICUM. "Japanese Privet." 20 leet. A large shrub or small tree, with glossy, dark green, leathery leaves; often used for hedges and stands trimming well. Pkt. $10 \mathrm{c}, 0 z$. $25 \mathrm{c}, 1 \mathrm{~b}$. $\$ 2.50$.

MAGNOLIA GRANDIFLORA. 80 peet. One of the finest of American evergreen trees; the leaves are thick, bright green and rusty on the under side; flowers large, waxy-white and pragrant. Fresh seed frowers large, waxy-white and Pragrant. Fresh seed Irom

MELALEUCA ERICTFOTIA. "Bottle Brush." A large shrub with small, narrow leaves and spikes of yellowish-white. brush-like flowers. Pkt. $15 \mathrm{c}$.

M. ARMII.IARIS. "Bottle Brush." 15 feet. Of spreading growth with slender drooping branches covered with small soft green leaves. Flowers creamy white. Pkt. $15 \mathrm{c}$.

M. DECUssaTA. "Bottle Brush" 15 feet Large shrub with arching branches; leaves, small, otpos-
ite, gray green. Short spikes of lilac flowers. Pkt. 15c M. NESOPHILA. "Bottle Brush." A handsome shrub of spreading habit with gray green foliage and rosy lilac blossoms. Pkt. 15c.

4. HYPERICIFnIIA. "Bottle Brush." A tall shrub with pretty, bright green, opposite leaves, and producing large splkes of rich red flowers. Pkt. $15 \mathrm{c}$.

MELIA ATEDARACH UMBRACULIFORMIS. "TEXa: Umbrella Tree." A well known deciduous tree. The branches are erect and in a manner radiating from the trunk and with drooping foliage, give it the appearance of a gigantic umbrella. It is a handsome shade tree and will stand a great amount of some shade tree and will stand a
heat. Pkt. 10c, oz. 20c, lb. $\$ 2.00$.

METROSIDFROS TOMENTOSA. A beautiful shrub from New Zealand. Leaves thick and leathery, green on the upper slde but whitish beneath. The howers apear in rounded terminal clusters, and are renappear in rounded terminal clusters, and are rendered particularly showy by their profusion of long
crimson stamens. It forms a partlcularly handsome crimson stamens. It lorms a partlcularly handsome shrub at any time, but when in flower w
attention from quite a distance. Pkt. 25c.

MYRTUS CoMMUNIS. "Common Myrtle." Handsome shrub of rather compact growth, with small, glossy green, aromatic leaves. Bears quantities of small, white, fragrant flowers. Valuable either for single plants or for a hedge. Pkt., 15c; oz., 50c.

PARKINSONIA ACUIEATA. Shrub or small tree. 15 to 25 feet. It has thorny, drooping branches, with lnng, feathery foliage, and showy yellow flowers. Pkt., 15c: oz.. $75 \mathrm{c}$. 
PEPPER TREE. See Schinus.

PICEA EXCELSA. 'Norway Spruce." 150 feet. A magnificent tree; the branches assume a very gracePkt. $15 \mathrm{c}, 0 \mathrm{z}$. $50 \mathrm{c}$, 1b. $\$ 5.00$.

PINUS AUSTRIACA. "Austrian or Black Pine." 100 feet. A spreading tree; leaves in pairs about inches long, rigld, very dark green. Pkt. 15c, oz. 50c, 1 b. $\$ 5.00$.

P. Canariensis. "Blue Pine." 80 feet. A beautiful tree with long pendant needles of a glaucous blue color. It is of rapld growth, stands drought well and is one of the best pines for Southern Callfornia. It has the peculiarity of sprouting from the stump when cut down or even burnt off, which is a valuable feature in the reforesting of our mountains. Pkt. 15c, oz. 50c, 1b. $\$ 5.00$.

P. Coulteri. "Big Cone Pine." 80 feet. A native specles from the San Bernardino and San Jacinto Mountains at an elevation of 4500 to 7000 feet, but, unlike most of our native pines from high altitudes, it succeeds well under cultivation in the valley. It has rough bark, the needles are in clusters of three, stiff and erect and of a dark blue green color. Pkt., 15c; oz. 60c; 1b., $\$ 6.00$.

P. Halepensis. "Aleppo Pine." Western Asia, 60 feet. A tree of rapld growth and spreading habit. with light yellowish-green follage. It thrives well in Callfornia, and is a valuable ornamental tree. Pkt. $15 \mathrm{c}, 0 \mathrm{z}$. 50, 1b. \$5.00.

P. INSIGNIS, (P. radiata.) "Monterey Pine." 100 feet. A well known native species of rapid growth. succeeding best near the coast. Pkt., 15c; oz., 50c; lb., $\$ 5.00$

P. MARItima. (P. pinaster.) "Seaside Pine." Southern Europe. 60 feet. A beautiful tree with deep furrowed bark, needles a bright glossy green, 6 to 9 inches in length; valuable for planting along the coast. Pkt. $10 \mathrm{c}, 0 \mathrm{z}, 30 \mathrm{c}, 1 \mathrm{~b}$. $\$ 3.00$.

P. MURICATA. "Bishop Pine." A native Callfornia specles, found growing on swampy flats and low hills from San Luis Obispo northward, always near the coast. It forms a tree 40 to 80 feet high, with roundish or flat top, and is valuable for wind break roundish or flat top, and is valuable for wind breaks produced in circles around the maln t-ink from near the ground to its summit, and also on the main branches. These cones are persistent for an indefinite time, often 15 to 25 years, and give the tree a most unique appearance. Pkt., 15c; 0z., 90c; Ib., $\$ 9.00$

P. PARRyana. (P. quadrifolla.) "Parry's Nut Pine." A small tree from 15 to 30 feet high, with rounded top and short needles from 1 to $1 \frac{1}{2}$ inches long of a glaucous color. Found in the dry mountains of Diego County. Pkt., 10c; oz., 50c; 1b., \$5.00.

P. PINEA. "Italian Stone Pine." 60 feet. A very picturesque tree; branches spreading and usually confined to the top of the tree. Pkt. 10c, oz. 30c, lb. $\$ 3.00$

P. SABINIANA. "Sabin's Nut Pine." A native treo found in Antelope Valley and from there northward; needles light green or glaucous, three in a cluster and drooping. It succeeds well under culti vation and forms a handsome tree. Pkt. 10c, oz rac. Ib. $\$ 3.00$.

P. TORREYANA. "Torrey PIne." A native pine found on the bluffs at Del Mar, in San Diego County; rather small tree of spreading habit, needles long and five in a cluster: succeeds well under cultivation Pkt., 15c; oz., 60c; ib., $\$ 6.00$.

P. TUBERCULATA. (P. attenuata.) "Knob Cone Pine." A native species especially valuable for dry hillsine. Handsome light green follage. Pkt., 15c; oz., 90c: Ib., $\$ 9.00$.

PITTOSPORUM EUGENIOIDES. 20 feet. A handsome shrub of upright growth, with light green leaves and dark stems. Very pretty for hedges and also as sin. gle specimen plants. Pkt., $15 \mathrm{c} ;$ oz., $\$ 1.00$.

P. PHILlyaneides. A rare and graceful tree attaining a height of 20 to 25 feet. In habit and general appearance it resembles the Weeping Willow. having drooping branches and narrow green leaves. but it has the advantage of being an evergreen tree. Put. $25 \mathrm{c}$.

P. CRASSIFOLIUM. A tall growing shrub, with grey green, downy follage and small deep red flowers. Thrives especially well near the coast. Pkt. 15c. oz. $75 \mathrm{c}$.
P. NIGRICANS. Shrub of upright growth; small shing green leaves and dark, almost black stems. Pkt. $15 \mathrm{c}, 0 z$. $\$ 1.00$.

P. TOBIRA. A handsome shrub, with dark green, shiny leaves and numerous white, fragrant flowers. Pkt. $15 \mathrm{c}$, oz. $60 \mathrm{c}$.

P. RHOMBIFOLIUM. A beautiful tree and highly recommended for street planting. It is of compact growth and the follage is of $a$ bright, rich green. It bears large umbels of white, fragrant flowers, followed by orange-cnlored berries in the fall of the year. Pkt., 25c; oz., $\$ 1.00$.

P. UNDULATUM. A shrub or small tree, with large lance-shaped, deep green, glossy leaves and white fragrant fowers. It makes a splendid hedge and is very handsome as single speclmen plants; also suitable for street trees. Pkt. $15 \mathrm{c}, 0 \mathrm{z}$. $60 \mathrm{c}$.

PRIVET. See Ligustrum.

PRUNUS CAROLINIANA. "Carolina Cherry." A large shrub or small tree of pyramidal growth; pretty, glossy green leaves and white flowers. Makes a April. Pkt., 10c; oz., 25c; 1b., \$2.50.

P. ILICIFOLIA. "Callfornis Cherry." A beautlful na. tive shrub found in most of our foothills. It has pretty, holly-like follage and small white flowers; very fine for single specimens and also makes a splendid hedge. Fresh seed from November to April. Oz. $15 \mathrm{c}, 1 \mathrm{~b}$. $\$ 1.50$.

P. INTEGRIFOLIA. "Catalina Cherry." From Catalina Island. A tree of great beauty, leaves large, oval, rich, glossy green; very pretty as single speclmens or as a street tree. Fresh seed from Novem. ber to April. Pkt. 10c, oz. 15c, Ib. $\$ 1.50$.

PSIDIUM CATTLEYANUM. "Strawberry Guava." A small shrub grown for the fruit, which is round, deep claret color, of strawberry fiavor. Much used for Jellies and preserves, also for eating fresh. Pkt. $15 \mathrm{c}, 0 \mathrm{z}$. $60 \mathrm{c}$. $1 \mathrm{~b}$. $\$ 6.00$.

PYRACANTHA ANGUSTIFOLIA. A shrub of upright spreading habit, with small narrow foliage and covered during winter with bright orange red berries. 10c; oz., 40c; 1b., \$4.00.

P. CRENULATA. Much branched shrub of rather dense growth; narrow dark green foliage, small deep red berries. Makes a splendid hedge plant. Pkt., $10 \mathrm{c} ; \mathrm{oz}$. c; lb., $\$ 4.00$

P. LALANDI. "Burning Bush." A thorny, thick-growing shrub with small dark green leaves and white flowers, followed by masses of orange colored berries which are particularly attractive, remaining on the plant all winter. Pkt., 10c; oz., 40c; lb., \$4.00.

P. YUNNANENSIs. A very desirable shrub lately introduced from Yunnan, China. It is of low spreading habit, many of the branches being perfectly prostrate. The foliage is rich dark green, and in fall and winter the foliage is rich dark green, and in fall and winter the plants are literally covered with brilliant scarlet
berries. For covering banks this shrub probably has berries. For covering banks this shru
no equal. Pkt., $10 \mathrm{c} ;$ oz., $40 \mathrm{c}$; lb., $\$ 4.00$.

RAPHTOLEPIS JAPONICA. ( $R$, ovata) Japan. 12 feet. A beautiful compact shrub of rather slow growth. The leaves are oval, thick and leathery, and of a dark, rich green In spring the plants are covered with white, fragrant flowers. Pkt. 10c, oz. 30c. Ib. $\$ 3.00$

R. INDICA HYBRIDA. A cross between $R$. indica and R. japonica. A very handsome shrub of rather compact growth with rich green foliage and many large oz. 40c; lb., \$4.00.

ROBINIA PSEUDACACIA. "Tellow or Black Locust" 60 feet. A deciduous tree of rapid growth, largely used for planting on timber claims. Handsome plnnate follage: flowers pea-shaped, white, fragrant, in slender drooping racemes. Pkt. $10 \mathrm{c}, 0 \mathrm{z} .25 \mathrm{c}$, 1b. $\$ 2.50$.

RHUS LAURINA. "Sumach." A native shrub, of compact form with smooth green follage and small white flowers. Pkt. 15c; oz., 50c.

gChINUS MoLLE. "Pepper Tree." Peru. 50 feet. The most graceful of all our cultivated trees; with its long branches of finely cut, dellcate green leaves and coral red berrles. It is the admiration of pvery tourist who visits our state. Oz., 10c; 1b., \$1.25.

๑. TER EBinthif OLIUS. "Brazillan Pepper." 40 feet. Of upright spreading growth, leaflets larger than in the preceding. Large, erect clusters of coral red berries appearing in winter. Pkt. $15 \mathrm{c}$, oz. $50 \mathrm{c}$. 
oCIADOPytis VERTiCillata. "Umbrella Pine." Japan. 100 feet A remarkably handsome tree of slow growth, doing well in California near the coast; well suited for planting on lawns. Branches in regwell suited for planting on lawns. Branches in reg-
ular whorls, covered with deep green, narrow leaves 3 to 5 inches long. Pkt. $15 \mathrm{c}$, oz. $75 \mathrm{c}, 1 \mathrm{~b}$. $\$ 7.50$.

sequora Gigantea. "California Big Tree." 300 feet. A magnificent tree of perfect pyramidal form. Foliage bluish green. Pkt., 25c; oz., \$2.50.

s. SEMPEir VIrens. "California Redwood." 300 feet. Of rapid growth; a splendid ornamental tree, sucgreen, paler underneath. Pkt. 15c, oz. $50 \mathrm{c}, 1 \mathrm{~b}$. $\$ 5.00$.

SPARTIUM JUNCEUM. "Spanish Broom." 10 feet. A quick growing shrub of upright habit. Large, yellow, pea-shaped flowers in great prof
round leafless branches. Pkt. 15c, oz. $50 \mathrm{c}$.

S. MULTiflon UM ALBUM. "White Portugal Broom." 8 feet. A pretty shrub with large, white, pea-shaped flowers. Pkt. 15c, oz. $75 \mathrm{c}$

S. SCOPAIRIUM. "Scotch Broom." 6 feet. A rather thick growing shrub; bright green stems and yellow pea-shaped flowers Pkt. $15 \mathrm{c}$, oz. $50 \mathrm{c}$.

STERCUIIA ACERIFOLIA. (Brachychiton acerifolium.) "Flame Tree." 50 feet. A tree of rather sturdy habit, with deeply-lobed, maple-like leaves; produces scarlet flowers in clusters which stand wel up above the foliage. Pkt. $15 \mathrm{c}$, oz. $60 \mathrm{c}, 1 \mathrm{~b}$. $\$ 6.00$.

S. DIVERSIF OLIA. "Victorian Bottle Tree." 60 feet. Of compact pyramidal growth; leaves bright, glossy green and of many different shapes. Thrives with small amount of water and has been largely planted as a street tree. Pkt. $10 \mathrm{c}, 0 z$. 50c, 1b. $\$ 5.00$.

THUJA OCCIDENTALIS. "American Arborvitae." "White Cedar." 60 feet. A handsome tree for single specimens and also for high hedges or screens. The foliage is bright green, lighter underneath and as. sumes brown or bronze tones in the winter. Pkt. $15 \mathrm{c}, 0 \mathrm{z}$. $75 \mathrm{c}, 1 \mathrm{~b}$. $\$ 7.50$.

T. ORIENTA LIS. (Biota orientalis.) "Chinese Arborvitae." 25 feet. A small thick growing pyramidal tree. Bright green foliage turning bronze or brown in the winter. Desirable as single specimen trees or for hedges. Pkt. 10c; oz. $40 \mathrm{c}$, 1b. $\$ 4.00$.
T. ORIENTALIS AUREA. “Golden Arborvitae." 10 feet. A form of the preceding; the follage assumes a golden tint in spring: very regular and compact in growth. Pkt. $15 \mathrm{c}, 0 \mathrm{z}$. 50c, $1 \mathrm{~b} . \$ 5.00$.

T. ORIENTALIS COMPACTA. 8 feet. A dwarf, very compact form of the Chinese Arborvitae. Pkt. 10c. oz. $40 \mathrm{c}, 1 \mathrm{~b} . \$ 4.00$.

TORREYA CALIFORNICA. "California Nutmeg." 75 feet. A beautiful native tree, somewhat resembling the English $Y$ ew in appearance. Forms large, compact head; leaves 1 to 3 inches long, dark, shining green. Pkt. $10 \mathrm{c}, \mathrm{oz} 20 \mathrm{c}, \mathrm{lb} . \$ 2.00$.

TRISTANIA CONFERTA. "Brisbane Box." A particularly beautiful tree, with large, handsome foliage and white flowers. It forms a dense compact head and is very ornamental for single specimen trees. and also for street planting. Pkt. 25c.

ULEX EUROPAEUS. "Gorse" or "Furze." 4 feet. A low growing, prickly shrub, with yellow, pea-sliaped flowers. Pretty for grouping; also makes a gond hedge. Pkt. $15 \mathrm{c}$, oz. $50 \mathrm{c}$.

UMBELLULARIA CALIFORNICA. (Oreodaphne callfornica.) "California Laurel" or "Bay" 80 feet Found growing near streams in many of our canyons, where it forms a large shrub or small treo. Farther north, however, it reaches a height of 80 feet or more. Under cultivation it grows rapldly and forms a well shaped, compact tree suitable for green foliage. Oz. 15c, lb. $\$ 1.50$.

UMBRELLA TREE. See Melia.

VIBURNUM TINUS. "Laurestinus." 12 feet. A well known shrub with showy umbels of white flower blooming profusely in the winter. Makes a splendid hedge. Pkt., 10c; oz., 40c; lb., $\$ 4.00$.

WIGANDIA MACROPHYLLA. ( $W$. caracasana.) A shrub attaining a height of from 15 to 20 feet, re markable for its leaves of immense size and large trussez of violet-blue flowers. Pkt. 25c.

Wistaria ChINensis. "Chinese Wistaria." A splendid, rapid growing, deciduous climber, producing long pendulous clusters of pale blue, pea-shaned flowers. Pkt. 15, oz. $50 \mathrm{c}$.

\section{Palm and Decorative Plant Seeds}

The seeds of all the species offered here, except the Cocos, can be germinated without artificial heat. Sow the seeds thickly in shallow boxes of light soil mixed with about the same quantity of leaf-mold. When a few inches high pot up into small pots. Some species are very slow to germinate, while others will come up in 5 or 6 weeks. Washingtonia filifera and W. robusta, Phoenix canariensis and P. reclinata can be sown in the open ground in spring after the weather has become warm and will germinate easily.

CHAMAEROPS EXCELSA. (Trachycarpus excelsus.) "Wind-mill Palm." China Japan and India. 30 feet. One of the hardiest palms known, standing heavy winds without injury to the leaves and also several degrees of frost. The leaves are fan-shaped finely and deeply cut. One of the best palms for street planting. Oz. $20 \mathrm{c}, 1 \mathrm{~b}$. $\$ 2.00$.

C. HUMILIS. The Mediterranean region. 20 feet. A dwarf growing hardy species, with fan-shaped leaves, especially desirable for lawns, also for growing in tubs for porch plants. Oz. 20c, 1b. $\$ 2.00$.

D. HUMILIS ARGENTEA. Similar to the last, but with more silvery foliage. 10 seeds $15 \mathrm{c}, 100$ seeds $\$ 1.00$.

cocos. A large genus of very beautiful pinnateleaved palms from tropical and semi-tropical South America. Many of the species are quite hardy in California and are especially desirable for planting California and are especially desirable for planting pans as mentioned for other palms, but require botpans as mentioned for other palm

Cocos ALPHONSEI. Stocky habit; rather quick growth for this group of palms. The leaves are blue-green, beautifully arched. The seeds are covered with edible pulp of rich apricot flavor. One of the hardiest of all palms, having stood in Northern the hardiest of all palms, having stood in Northern 8 degrees Fahr. 10 seeds $20 \mathrm{c}, 100$ seeds $\$ 1.50$.

C. AUSTRALIS. "Pindo Palm." 15 feet. A rather slow growing but very ornamental palm with glaucous green recurved leaves. One of the hardiest of the genus and the one best known in California. 10 seeds $15 \mathrm{c}$, 100 seeds $\$ 1.00$
C. BONNETTI. A very graceful palm. Leaves graygreen in color when in full sunshine, but when grown in houses, of a darker green. One of the best for house culture and also quite hardy out of doors in California. 10 seeds $20 \mathrm{c}, 100$ seeds $\$ 1.50$.

C. BOTRYOPHORA. A very handsome palm similar to C. plumosa, but of more rapid growth and the best of the tall growing class. 10 seeds, 20c; 100 seeds, $\$ 1.50$.

C. CAMPESTRIS. 10 to 15 feet. Leaves spreading and recurved, but slightly rigid. 10 seeds $20 \mathrm{c}, 100$ seeds $\$ 1.50$

C. DATIL. Similar to C. plumosa, but much hardier thriving in sections where the latter will not survive. 10 seeds, 20 c; 100 seeds, $\$ 1.50$.

C. ERIOSPATHA. 10 to 15 feet. Leaves blue-green in color. The seeds are covered with edible pulp of a rich flavor. One of the best of the hardy Cocos. 10 seeds $20 \mathrm{c}, 100$ seeds $\$ 1.50$.

Cocos PLUyosa. Brazil. 50 feet. The best for street planting and largely planted in Santa Barbara. It is a rapid growing palm with slender trunk, crowned with graceful pinnate leaves. 10 seeds $20 \mathrm{c}, 100$ seeds $\$ 1.50$.

C. YATAX. 12 to 15 feet. Leaves recurved, spreading 6 to 9 feet long similar to C. australis in genera appearance. 10 seeds $20 \mathrm{c}, 100$ seeds $\$ 1.50$.

ER YTHEA ARMATA. "Blue Palm." Lower California. 40 feet. A rather slow growing Fan Palm. Leaves of a fine glaucous blue. Very hardy and 8
pretty palm for lawns. 10 seeds $20 \mathrm{c}, 100$ seeds $\$ 1.50$. 
E. EDULIS. "Guadalupe Palm." Guadalupe Island. 30 feet. A rapid growing Fan Palm of great beauty. Leaves deep green and without any threads. 10 seeds $15 \mathrm{c}, 100$ seeds $\$ 1.00$.

PHOENIX CANARIENSIS. "Canary Island Palm." Without doubt the most popular in California and one of the most graceful of our hardy palms. Leaves pinnate and of a deep dark green color. Very effective for lawns and large grounds. 10 seods 10c, 100 seeds $50 \mathrm{c}$.

P. DACTYLIFERA. "Fruiting Date Palm." Arabia and North Africa. 100 feet. Produces the dates of commerce. Of rather stiff growth when young and not very ornamental, but when fully developed it is hard to be surpassed for scenic effect. Oz. 20c, lb. $\$ 2.00$.

P. LEONENSIS. ( $P$. spinosa.) Africa. 40 feet. A large palm of strong growth, attaining about the same proportions as P. canariensis. Fronds with a slightly glaucous tinge, armed at the base with formidable spines. 10 seeds $15 \mathrm{c}, 100$ seeds $\$ 1.00$.

P. RECLINATA. South Africa. 12 to 20 feet. Of slender, graceful habit. Pinnate leaves beautifully arched, usually hanging edgeways. A fine palm for avenue planting or for single specimens on lawns. 10 seeds $15 \mathrm{c}, 100$ seeds $\$ 1.00$.
P. ROEBELENI. Siam. A beautiful little specie growing only a few feet high, with finely cut leaves, especially valuable for growing as a pot plant. 10 seeds $25 \mathrm{c}, 100$ seeds $\$ 2.00$.

PHOENIX RUPICOLA. India, 20 to 30 feet. A palm of slender, graceful habit, suitable for single specimens or avenue planting. Very desirable in the young state as a pot plant. 10 seeds, $20 \mathrm{c} ; 100$ seeds, $\$ 1.50$.

WASHINGTONIA FILIFERA. "California Fan Palm." 30 reet. The common Fan Palm of California. Trunk attains a diameter of 4 feet. Leaves fan-shaped with numerous divisions and whitish flaments. Oz. With numero $15 \mathrm{c}, 1 \mathrm{~b}$. $\$ 1.50$.

W. ROBUSTA. (W. gracllis.) 100 feet. Of more slender growth than the preceding and more graceful in general appearance. The leaves are brighter green and with less fllaments. This is the palm largely used for street planting. Oz. 25c, 1b. \$2.50.

W. SONORAE. Lower California. 25 feet. A beautiful palm resembling the well-known California Fan Palm, but more symmetrical in growth and more dwarf in habit. The leaves are of medium size with lew or no filaments and retain their dark green color during the winter months. Leaf stem ghort and thorny of unifht sheaths. Oz. 35c, lb $\$ 3.50$. growth with dark lear-

\section{DECORATIVE PLANT SEEDS}

Sow the seed in pots or boxes of light, well-drained soil; when plants are large enough to handle pot up into small pots and transfer to larger pots or plant out in the open ground, as desired.

ASPARAGUS PLUMOSUS. “Asparagus Fern." A favorite climbing vine, suitable for shady locations. Also grown as a pot plant. Soak the seed in hot water 12 hours before sowing. Pkt. 10c. 100 seeds $50 \mathrm{c}$

A. SPRENGERI. A favorite plant for hanging baskets. Treat the seed the same as the preceding variety. Pkt. 10c, 100 seeds $30 \mathrm{c}$

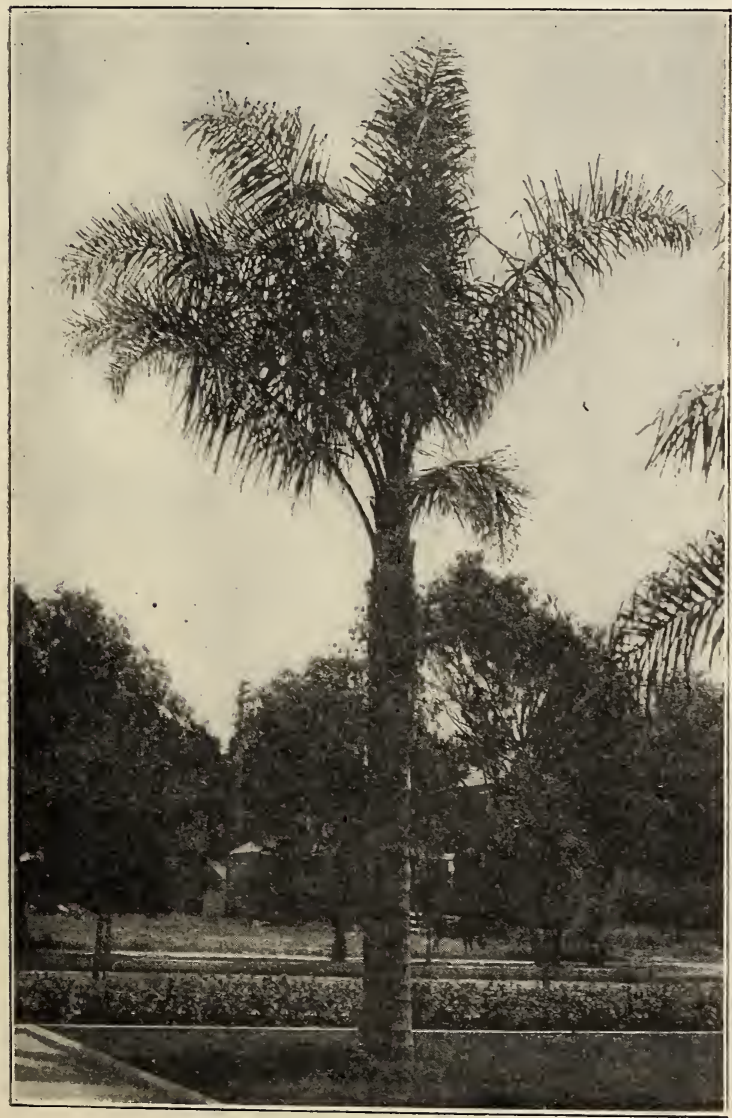

Cocos plumosa- "Queen Palm"
DORYANTHES PALMERI. A valuable decorative plant from Australia. The plants throw up numerous leaves 5 to 7 feet long, and flower stems 8 to 10 feet high, each bearing a large thyrsus of deep scarlet flowers. It takes the plants several years to reach the blooming stage, but the young plants are very valuable for decorative pot plants. 25 seeds $25 \mathrm{c}, 100$ seeds $75 \mathrm{c}$.

DRACAENA AUSTRALIS. (Cordyline australis.) New Zealand. 20 feet. A popular plant for pot culture also for lawns and street planting. Forms a stout branched stem with broad leaves 2 to 3 feet long. Pkt. $15 \mathrm{c}$, oz. $60 \mathrm{c}$.

D. DRACO. "Dragon Tree." Canary Islands. 50 feet. Forms a stout stem crowned with numerous swordshaped leaves. 10 seeds $10 \mathrm{c}, 100$ seeds $75 \mathrm{c}$.

D. INDIVISA. (Cordyline indivisa.) New Zealand. 30 feet. Grows much more rapidly than either of the preceding, with long narrow leaves and slender stems. Pkt. $15 \mathrm{c}, \mathrm{oz}$. $50 \mathrm{c}$.

MUSA ENSETE. "Abyssinian Banana." A splendid decorative species forming a single stout trunk and immense broad leaves 10 to 15 feet long. 10 seeds $25 \mathrm{c} .100$ seeds $\$ 2.00$.

PHORMIUM TENAX. "New Zealand Flax", 6 feet. A fine plant for sub-tropical beds. Large, erectgrowing, dark green leaves. Pkt. $15 \mathrm{c}$, oz. $75 \mathrm{c}$.

STRELITZIA NICOLAI. South Africa. 15 to 20 feet. A rare species with large flowers of grotesque form, white and blue. Forms a heavy stem and large, broad leaves. Soak the seed in hot water for 24 hroad leaves. Soak the seed in hot water for 24 heat in germinating this seed, though it has boen grown fairly well without. 10 seeds $25 \mathrm{c}, 100$ seeds grow

TUCCA BACCATA A rizona, of low, compact growth leaves rigid, with thick margined threads. Flower spikes 5 to 6 feet long. Pkt. $15 \mathrm{c}, 0 z$. $\$ 1.00$.

YUCCA BREVIFOLIA. "Joshua Tree." California, Nevada and Utah. 20 to 30 feet. A peculiar plant with stout trunk and open crown of arm-like branches. Leaves bluish green $1 \frac{1}{2}$ inches wide at the base tapering toward the apex, the edge furnished with mipering toward the apex, the edge furnished with minute teeth; flowers greenish white. Growing in impart a singularly weird appearance to the landscape. Pkt., 15c; oz., $\$ 1.00$.

YUCCA WHIPPLEI. "Spanish Bayonet." California. A magnificent plant with narrow glaucous green leaves. Flower stems 8 to 15 feet high with often two, three and even six thousand waxen, pendulous two, three and even six thou

We carry a complete stock of tree and palm seeds, including many rare and valuable species. All stock is of uniform high vitality; write us on varieties not listed. 


\section{The Rose Garden}

The rose has been aptly called the "Queen of Flowers" and it would be hard to picture a garden being complete without them. Considered either from points of sheer beauty in the garden or cut flower value they are equally appealing; their colors, fragrance and universal hardiness in any locality make them what might be termed a garden staple, yet the romance and sentiment that is so firmly attached to them removes any possible suggestion of commonness. No garden could possibly have too many roses, and the following list, while not extensive, includes the best varieties in their classes for fill. ing any requirement in color or type. Please read instructions on second page of cover before ordering.

COLUMBLA. Hybrid Tea. A charming shade of rose pink tinted silver at the outer edges. Free flowering and fragrant, the flowers lasting well in favored locations and when cut. A vigorous grower and one of the best pinks. Each, 60c.

CONSTANCE. Pernetiana. Shapely orange yellow buds streaked with crimson, opening to a full round flower in various shedes of yellow. Quite distinct in shape and color and a profuse bloomer. Each, $75 \mathrm{c}$.

FRAU KARL DRUSCHKI. Hybrid Perpetual. Pure snow white, large perfect flowers on long stems; free flowering; rich handsome foliage. One of the best whites. Each, 60c.

GENERAL McARTHUR. Hybrid Tea. Considered by many as the best of the red roses. Bright red or scarlet, fragrant, with flat open flowers on strong rigid stems. Each, $60 \mathrm{c}$.

GOLDEN EMBLEM. Hybrid Tea. One of the very best of the new roses. Long pointed buds, golden yellow beautifully shaded with crimson on the outer petals, opening to a clear golden yellow flower. Free and constant bloomer, vigorous grower with rich, deep, glossy green foliage. Each, $75 \mathrm{c}$.

GORGEOUS. Hybrid Tea. All the name implies in size and color. Deep orange yellow, veined with reddish copper. Flowers are double from a perfect oval bud, borne on erect strong stems. Each, $75 c$

HADI.EY. Hybrid Tea. Deep velvety crimson; flowers carried on long stiff stems. Flowers full and richly fragrant; foliage mildew proof. The best of the deep red hybrid tea roses. Each, 60c.
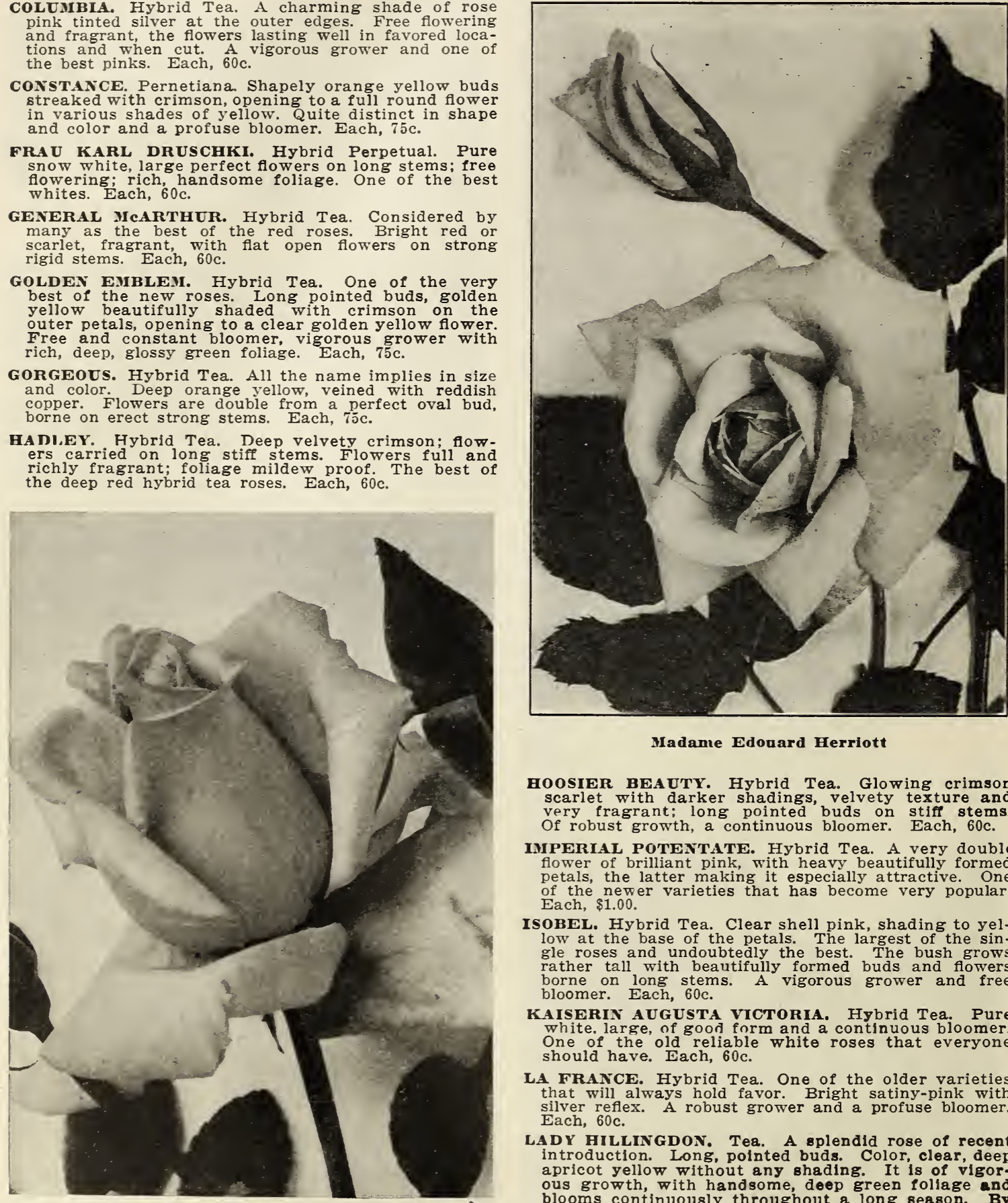

Madane Edouard Herriot

HoOsier BEAUTY. Hybrid Tea. Glowing crimson scarlet with darker shadings, velvety texture and very fragrant; long pointed buds on stiff stems.

IMPERIAL POTENTATE. Hybrid Tea. A very double flower of brilliant pink, with heavy beautifully formed petals, the latter making it especially attractive. One of the newer varieties that has become very popular. Each, $\$ 1.00$

ISOBEL. Hybrid Tea. Clear shell pink, shading to yellow at the base of the petals. The largest of the single roses and undoubtedly the best. The bush grows rather tall with beautifully formed buds and flowers borne on long stems. A vigorous grower and free bloomer. Each, 60c.

KAISERIN AUGUSTA VICTORIA. Hybrid Tea Pure white. large, of goor form and a continuous bloomer. One of the old reliable white roses that everyone should have. Each, $60 \mathrm{c}$.

LA FRANCE. Hybrid Tea. One of the older varieties that will always hold favor. Bright satiny-pink with silver reflex. A robust grower and a profuse bloomer. Each, $60 \mathrm{c}$.

LADY HILLINGDON. Tea. A splendid rose of recent introduction. Long, pointed buds. Color, clear, deep apricot yellow without any shading. It is of vigor. ous growth, with handsome, deep eren follage and blooms continuously throughout s long season. By many this is considered the best yellow rose yet in. troduced. Each, $75 \mathrm{c}$. 


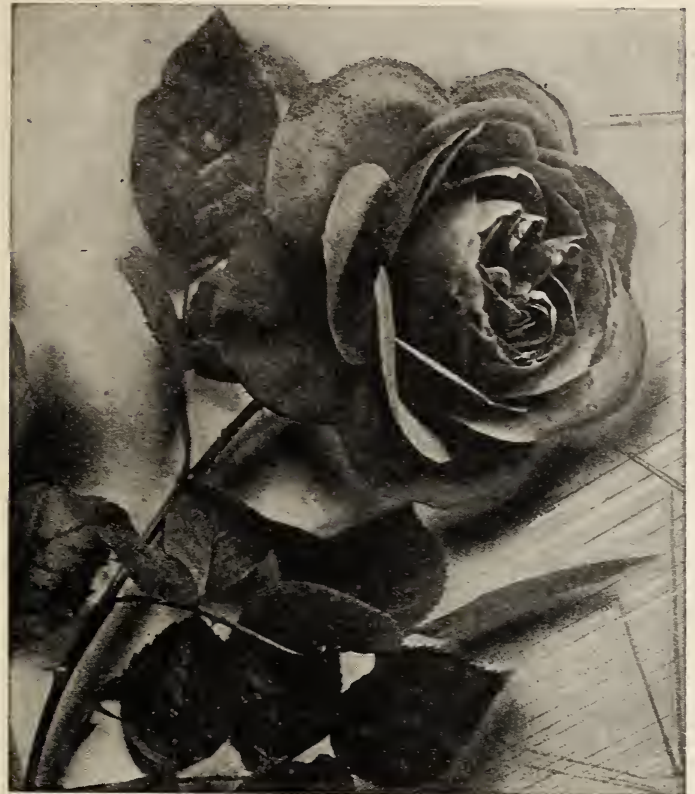

Hadley

LOS ANGELES. Hybrid Tea. A glorious rose of Southern California origin. In color it is distinct from any other rose grown, being a rich flame pink shaded with golden yellow. It proiuces nerfect buds and is a strong, vigorous grower. Each, 60c.

LOUISE CATHERINE BRESLAU. Pernetiana. Beauti ful coral red shaded chrome yellow changing to shrimp pink and coppery orange as the blossoms open. Quite distinct; of good habit. Each, $75 \mathrm{c}$.

MADAME CAROLINE TESTUUT. Hybrid Tea. Clear pink, large full flowers, very sweet. a strong grnwer and good bloomer. A favorite for many years. Each, $60 \mathrm{c}$.

MADAME CECIL BRUNNER. Polyantha. "The Baby Rose." Color salmon-rnse the finest of the minlature roses. Flowers exquisitely fragrant and beautifully formed. No rose garden is complete without it Each, 60c.

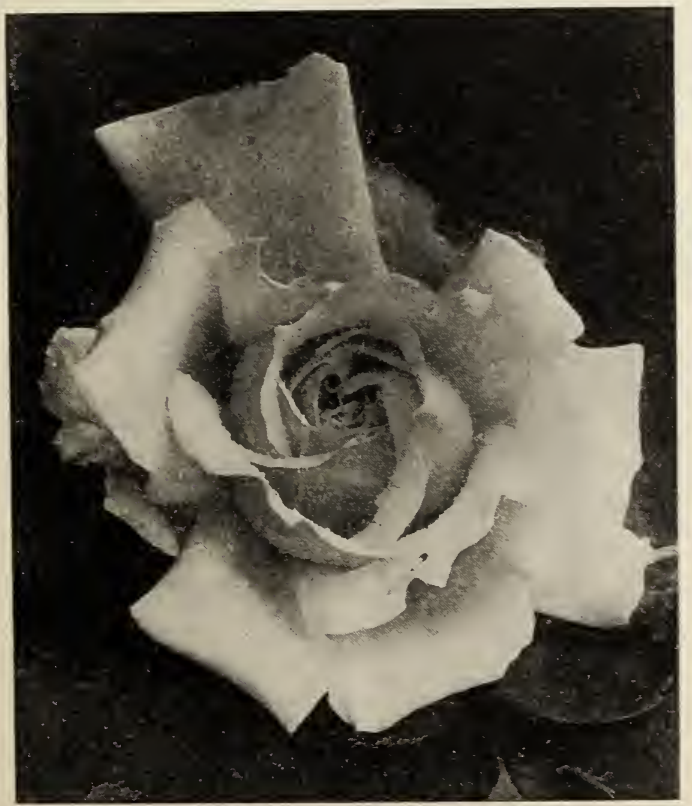

Los Angeles
MADAME EDOUARD HERRIOTT. Coral red shaded with yellow at the base, passing to shrimp red. One with yellow at the base, passing to shrimp red. One of the greatest rose novelties ever in troduced. Winthe Gold Medal of the National Rose Society of Ensthe Gold Medal

MRS. AARON IVARD. Hybrid Tea. Deep orange yellow shading to creamy yellow at the ends of the petals. The buds are cupped and very deep, showing the glowing heart to the best advantage. Each, $75 \mathrm{c}$.

OPHELIA. Hybrid Tea. Shell pink with darker shadings of pink and salmon. Exquisitely formed buds and flower, delightfully fragrant; not a profuse bloomer but exceedingly worth while when it does flower. Its fragrance alone would recommend it to every rose lover. Each, $75 \mathrm{c}$.

PADRE. Hybrid Tea. A most unusual and effective shade of intense coppery-scarlet. Semi-double flowers borne profusely on long straight stems. Habit exceptionally fine, making a tall erect bush of handsome appearance. The best of the newer red roses. Each, $\$ 1.00$.

PAUL NEYRON. Hybrid Perpetual. Deep rose; the largest of all roses, strong, erect grower. inrge.
handsome foliage. Flowers measuring six inches across are not unusual. Lasts well when cut. Each, $60 \mathrm{c}$.

RADIANCE. Hybrid Tea. A lovely rose pink with opal shadings. Very sweet scented: a strong grower and one of the most profuse bloomers of all roses. Very hardy and disease resistant. Each, 60c.

RED RADIANCE. Hybrid Tea. A glowing crimson sport of Radiance, with all the magnificent qualities of the parent. One of the best reds for general planting. Each, 60c.

ROSE MARIE. Hybrid Tea. Exquisitely formed flowers of rich deep pink, delicately veined and richly fragrant. Very free bloomer and one of the best deep pinks: foliage does not mildew. Each, 75c.

SENSATION. Especially desirable for its very large buds of crimson scarlet, shading to darker red as the flower opens. Flowers are very double and profusely borne on vigorous, free branching bushes. Good lasting qualities when cut. Each, $75 \mathrm{c}$.

SOUVENIR DE CLAUDIUS PERNE'T. Conceded to be the finest of all yellow roses. Vigorous grower, handsome bright green foliage with few thorns. Exquisite buds on long straight stems; flowers large and full, the color being purest yellow with no intervening shades. Each, $\$ 1.00$.

SUNBURST. Hybrid Tea. A grand new rose, very large and perfectly formed flowers and long, pointed buds, yellow shaded with orange, the outer petals of a lighter shade. Of strong, vigorous growth, sending up stout stems heavily clothed with handsome foliage. One of the very best roses of late introduction. Each, 75c.

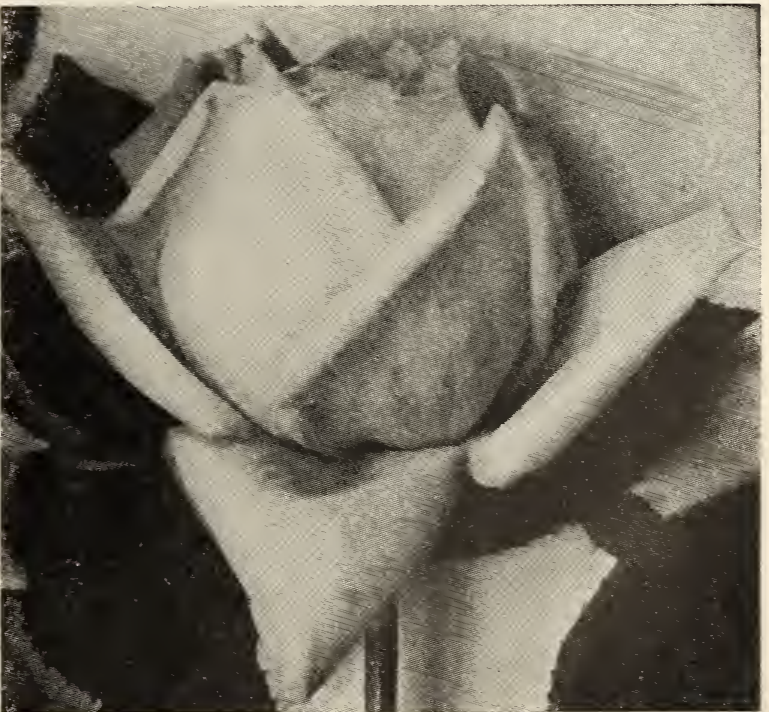

Rose Marie 


\section{Climbing Roses}

The climbing roses fill a very important position in the making of a colorful garden. For starting on trellises alongside the house or for covering pergolas, outhouses or for lining along a fence they lend charm, color and fragrance in a measure that would be difficult to equal and they have the added advantage of being very hardy. The following list offers a wide range of selection in color and type of flower, all plants being of vigorous two-year-old budded stock.

CLIMBING YELLOW BANKSIA. Flowers small, clear yellow, borne in great profusion. A vigorous grower

CLIMING BeLLE OF PORTUGAL. Hybrid Tea. Delightful shade of shell pink shaded with salmon. Very large flowers opening from long pointed buds. Fast and vigorous grower; one of the most attractive of all climbing roses. Each, $75 \mathrm{c}$.

CLIMBING CAROLINE TESTOUT. Hybrid Tea. Clear bright pink; large, well-formed flowers. Blooms in greater profusion than the bush variety. Each, 60c.

CHEROKEE WHITE. Single white, large yellow stamens, a lovely contrast against rich, glossy foliage, a rapid grower; valuable covering for fences, etc. Blooms in spring. Each, 60c.

CHEROKEE PINK. A climbing rose of rare beauty and without doubt one of the finest varieties ever introduced. The beautiful single flowers are produced in great profusion, in color a most charming duced in great profusion, in color a most charming plants are of rampant growth with bright, shining plants are of rampant growth with bright, shining green follage, and present
in full bloom. Each, $60 \mathrm{c}$.

CHEROKEE RED. Identical in habit and type with the pink form, only the flowers are deep red shading
to lighter red at the outside of the petals. Each, 60c.

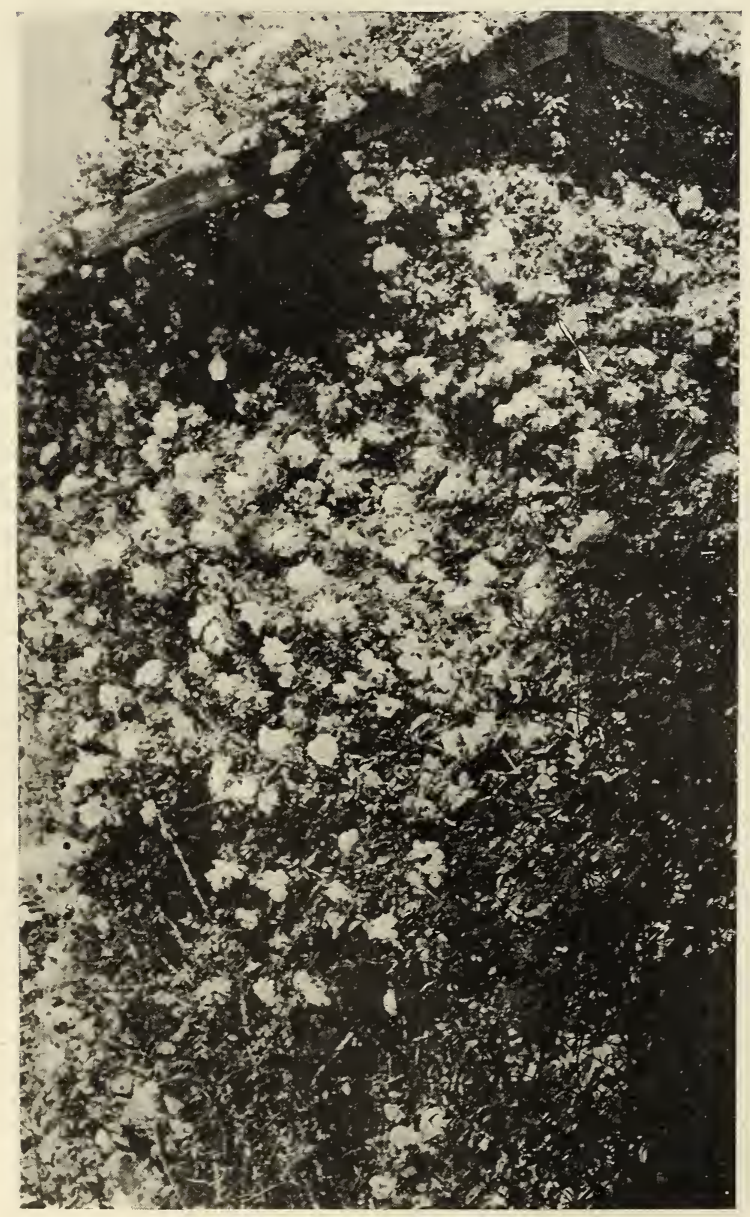

Climbing Lady Hillingdon
CLIMBING GENERAL MeARTHUR. Hybrid Tea. A vigorous climber, producing many bright red flowers practically the year around. Has all the fine points of the bush variety and is all that could be desired in a climber. Each, 60c.

CLIMBING HADLEY. Hybrid Tea. Fragrant, deep velvety crimson flowers in great quantities all during summer. A vigorous climber and a universal favorite. Each, 60c.

CLIMBING Hoosier BEAUTY. Hybrid Tea. Flowers of rich scarlet, the petals being of soft velvety texture and finely formed. Very hardy. Each, 60c.

CLIMBING KAISERIN. Hybrid Tea. Considered the best pure white climbing rose, continuous bloomer. Each $60 \mathrm{c}$.

CLIMIBING LADX HILLINGDON. Tea. Deep apricot yellow. One of the few fine yellow climbing roses. Blooms over a long period, the flowers being identical with those of the bush form. Each, 60c.

CLIMBING LOS ANGELES. Hybrid Tea. Equally free blooming as the bush variety and equally attractive. A vigorous climber, the whole plant being literally covered with flame pink flowers during the blooming period. Each, $75 \mathrm{c}$.

Chmibing Louise C. BReslad. Pernetiana. A worthy companion to the bush form. Coral red shading to pink and coppery orange as the flower opens. Each, 75c.

CLIMBING MADAME CECIL BRUNNER. Polyantha. Rosy pink, salmon center, free bloomer. One of the strongest of the climbing roses. Each, 60c.

CLMMBING SUNBURST. Hybrid Tea. The climbing form of this beautiful yellow rose. Exquisite golden yellow buds borne almost continuously. Each, 60c.

PAUL'S SCARLET CLIMBER. Flowers of an intense vivid scarlet borne in clusters of from three to twenty blooms on a single cane. A very striking rose in any situation. Each, 60c.

CLIMBING WHITE MAMAN COCHET. Tea. One of the best whites, having all the attributes of the bush form with the addition of its climbing habit. Each, $60 \mathrm{c}$.

\section{CARE AND PRUNing of roses}

In planting roses, first spade the ground to a depth of at least 18 inches, mixing in a small amount of well rotted dairy fertilizer. To prevent suckering they should be planted deep, about 3 inches of the budding mark being covered with earth, allowing a small mark being covered with earth, allowing a small basin at the base of the plant to retain moisture; a mulch of well rotted dairy fertilizer in this basin will

Roses should be pruned back during their dormant season, any time from late November to early February. Remove the small scraggly growth, leaving only the larger stocky canes that will preserve the symmetry of the bush. Suckers should be removed as symmetry of the bush. Suckers should be removed as retard the proper growth of the plant and reduce its flowering capacity.

\section{TREATMENT OF INSECTS}

For scale, red spider, aphis or thrips, spray with Destruxol Emulsion, mixing one pint of emulsion to each ten gallons of water, or in smaller quantities, three tablespoons to each gallon of water. Shake the can thoroughly before mixing and add the water very slowly, stirring vigorously until ready to spray. A thorough spraying with Destruxol not only removes the insects spraying with Destruxol not only removes the insects but acts as a stimulant to the plant, hence
valuable. Cannot be sent through the mails.

For mildew or curly leaf on roses a thorough spraying with soluble sulphur (Qua-Sul) will be found the easiest and best remedy; powdered sulphur can be used if more easily available, spreading it on the foliage in the early morning while the dew is on the plant or immediately after watering.

Roses will respond in just the measure of the care that is given them and the above directions, if followed carefully, will insure a robust growth and plenty of fine flowers.

Trench watering will greatly reduce mildew on roses; it is never advisable to top-water more than is necessary to keep the foliage bright and clean. Use plenty of plants start to go dormant in the Fall. 


\section{California Native Trees and Shrubs}

In making an attractive garden a very desirable combination of beauty and economy is obtained by using native trees and shrubs of California. They are very hardy, requiring water and care only until well established and their many types of growth and foliage can easily be made to create any desired effect. Their ornamental value is equal and in many cases superior to the exotic or imported group of trees and shrubs and, being native, their adaptability to climate and soil conditions gives them a decided advantage. Aside from the saving in maintenance at no loss in appearance, they lend a charm and interest to a garden that is obtainable in no other way. Many types of foliage and color combinations will be found in the following list. All are evergreen unless otherwise noted.

Acer macrophyllum. "California Maple." A deciduous tree of great beauty. Leaves large, deeply fine-lobed, rich green, paler beneath. Found growing along the sides of creeks in many of our canyons, but thriving under cultivation in the valleys. In gal. thriving under cultivation in the valleys. In gal.

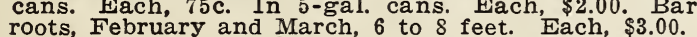

Acer negundo var. californicum. “California Box Elder." A beautiful deciduous tree of very rapid growth forming a dense, symmetrical, spreading crown. Desirable for shade in the garden and one of the very best trees for street and highway planting in localibest trees for street and highway planting in localities where a deciduous tree is desired.
Each, 75c. In 5-gal. cans. Each, $\$ 2.00$.

Adenostoma fasciculatum. "Greasewood." Evergreen shrub, 3 to $10 \mathrm{ft} .$. Small clustered needle-like leaves,
flowers white. A splendid shrub for hot dry places. In gal. cans. Each, 75 c. In 5-gal. cans. Each, $\$ 2.00$.

Aesculus calffornica. "California Buckeye." Deciduous tree with broad rounded top. Leaves large.
palmate, divided in from 5 to 7 leaflets. Flowers palmate, divided in from 5 to 7 leaflets. Flowers times pale pink. In gal. cans. Each, $75 \mathrm{c}$. In 5-gal. cans. Each, $\$ 2.00$.

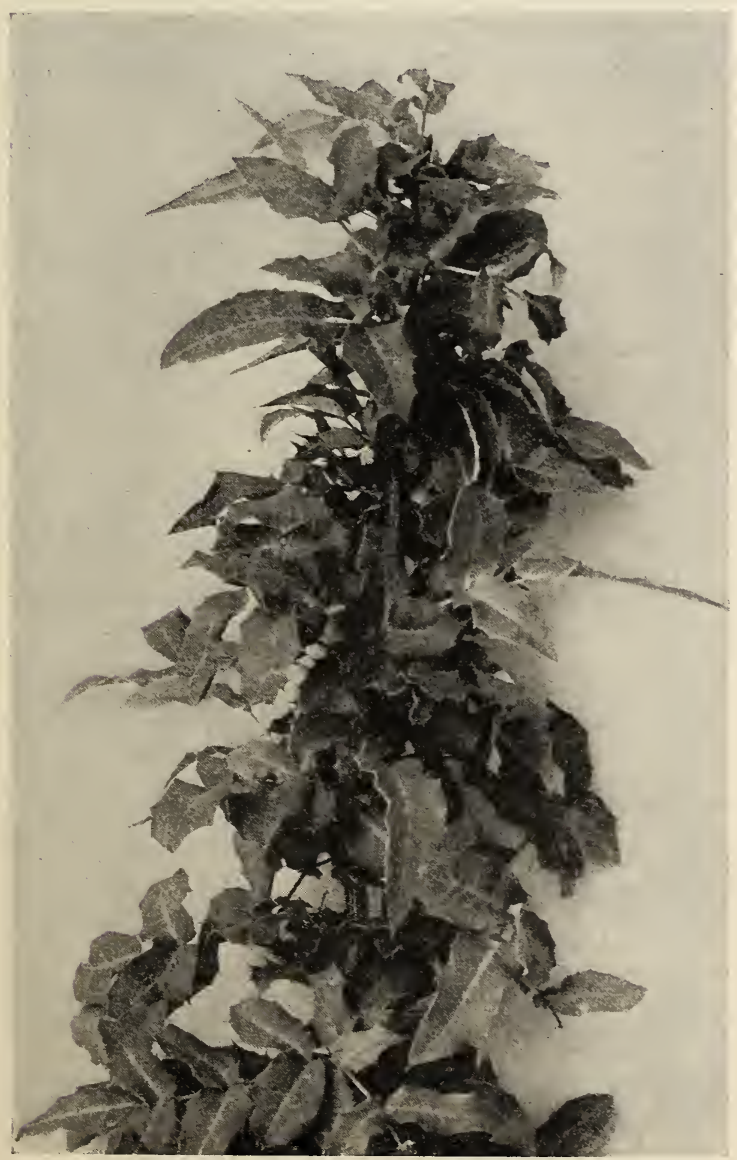

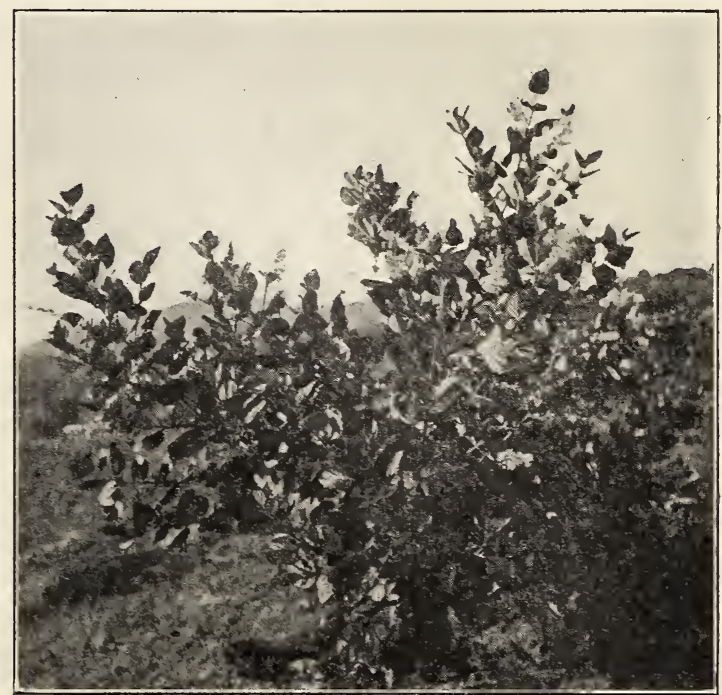

Ceanothus arboreus 10 months from gallon container

Alnus rhombifolia. "White Alder." A rapid growing deciduous tree found along creek beds but thriving perfectly well in any location if supplied with a fair amount of moisture. In the wild state the trees are found crowded together and are tall and slender. When planted out singly the trees make a thick, spreading, symmetrical growth. In 5-gal. cans. Each, $\$ 2.00$.

Antirrhinum speciosum. "Bush Snapdragon." A rare shrub from Catalina Island forming a much branched bush 4 to 8 feet high, producing quantities of scarlet flowers. In gal. cans. Each, $\$ 1.50$.

Arbutus menziesil. "Madrone." A beautiful tree with smooth red bark, handsome foliage and white fragrant flowers. In gal. cans. Each, \$1.50. In 5-gal. cans. Each, $\$ 3.00$.

Aretostaphylos glauca. "Giant-Berried Manzanita." An interesting shrub with crooked red-barked branches, handsome glaucous foliage and white urn-shaped flowers. Especially desirable for dry places. In gal. cans. Each, $\$ 1.50$

Audibertia nivea. "Button Sage." Small shrub especially valuable for dry places. Pretty silvery grey foliage and lilac blossoms, very beautiful when in bloom on the hillsides. In gallon cans, each $50 \mathrm{c}$.

A. polystachya. "White Sage." Valuable for dry places. Very beautiful grey foliage and tall spikes of white flowers. In gallon cans, each $50 \mathrm{c}$

A. stachyoides. "Black Sage." Valuable for dry places. Deep green foliage and purple flowers. In gallon cans, each $50 \mathrm{c}$.

Berberis Nevinii. "Nevin's Barberry", A very rare and beautiful shrub. Foliage silvery gray with bright canary yellow flowers borne in clusters, later turning into deep red berries. Very hardy, thrives in any soil with very little water, in sun or shade. Most attractively used either as a single specimen or as a hedge. In gal. cans. Each $75 \mathrm{c}$. In 5 -gal. cans. Each, $\$ 2.00$.

Berberis pinnata. "California Barberry." Small shrub of upright growth. Foliage rich green, deeply toothed and prickly. Flowers yellow, borne in racemes, followed by deep blue berries. Succeeds well
in either shade or sun. In gal. cans. Each, $\$ 1.00$. 
Calycanthus occidentalis. "Western Sweet-Scented shrul." Deciduous shrub with handsome foliage and chocolate brown flowers. In gal. cans. Each.75c. In 5-gal. cans. Each, \$2.00. Balled, 2 feet. Each, \$2.50.

Carpenteria callfornica, "Tree Anemone." A rare and beautiful shrub Flowers in clusters, usually of 5 to 7 , and occasionally 12 or more; large, pure white with yellow stamens and with a fragrance like the Mock Orange. In gal. cans. Each, 75c. In tubs, 2 to $3 \mathrm{ft}$., each, $\$ 2.50$.

Ceanothus. "California Wild Lilac." The Ceanothus is one of the most desirable of the native shrubs, having the combined advantages of evergreen foliage, beautiful and fragrant flowers and absolute hardiness. The group contains many habits of growth, types of foliage and color of flowers which can be made to fill attractively any location or soil. White, light blue, medium blue and dark blue flowered species will be found in the following list, any or all of which make a very desirable addition in a shrubbery group.

C. arboreus. From the islands off the coast of Southern California. A large shrub or small tree of rapid growth Flowers in large trusses, bright hlue: large.
handsome foliage. In gal. cans. Each, $75 \mathrm{c}$. In 5-gal. cans. Each, \$2.00.

Ceanothus arboreus hybridus. Hybrid of C. arboreus dild C. Spinusus. UI very rapid growth with large glossy green follage and immense trusses of bright hlue flowers. Very free flowering and one of the
best of the Ceanothl. In gal. cans. Each, 75c. In 5-gal. cans. Each, $\$ 2.00$.

C. cyaneus. A rare species from San Diego county and now offered for the first time. A sulendid shrub with dark green follage and large trusses of dark blue flowers, which appear late in spring after other kinds are over. In gal. cans. Each, 75c. In 5-gal. cans. Each, $\$ 2.00$

Ceanothus divaricatus. A shrub of spreading habit with somewhat arching branches, glaucous foliage and sky blue flowers. Found in the foothills and mountains up to 5000 feet elevation. In gal. cans. Each, tains up to 5000 feet elevation.
$75 \mathrm{c}$. In 5-gal. cans. Each, $\$ 2.00$.

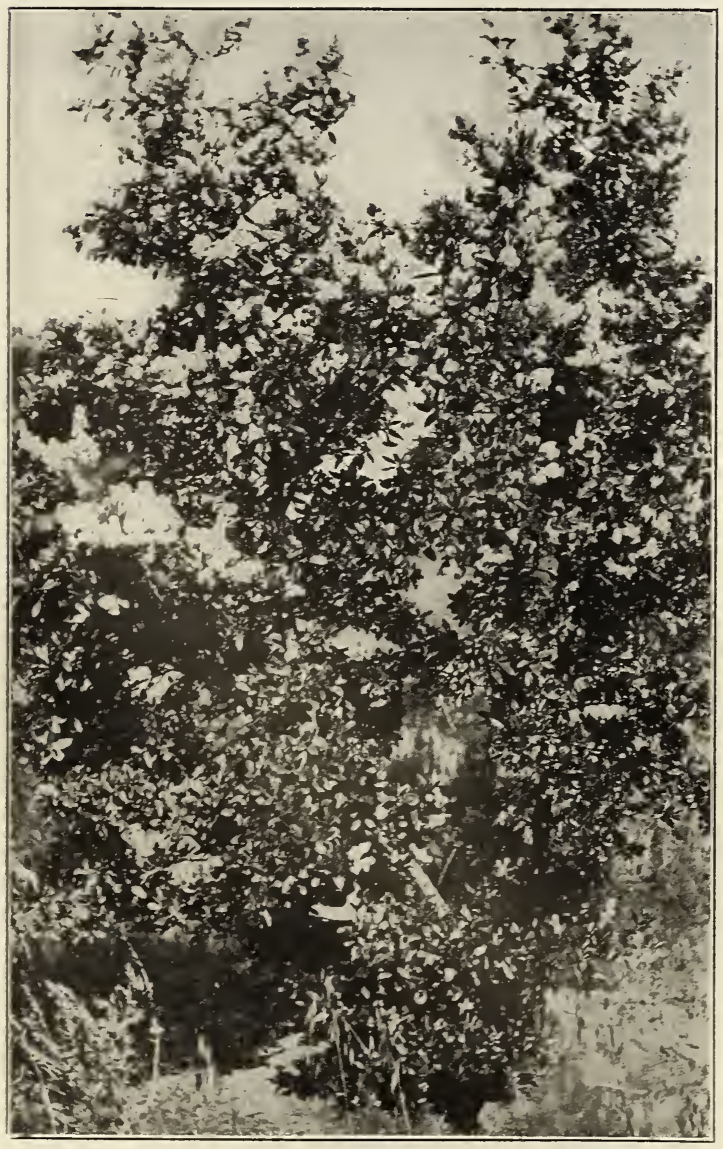

Ceanothus arboreus hybridus- "Callornia Wild Lilac"
Ceanothus integerrimus. "Deer Brush." A loosely branching shrub with greenish brown branches. Flowers in large trusses, white or sometimes pale blue. Found in the pine belt of our mountains. In gal. cans.

C. megacarpus. Of thick branching habit; small dark green follage, white flowers. In gal. cans. Each, 75 c. In 5-gal. can. Each, $\$ 2.00$.

C. spinosus. One of the most rapid in growth. Bright green stems and foliage. Flowers in large trusses, pale blue. In gal. cans. Each, $75 \mathrm{c}$. In 5-gal. cans. Each, \$2.00.

C. thyrsifiorus. One of the best of the Ceanothus for all-around use. Dark green shiny foliage with deep blue flowers, richly fragrant. Dense, compact growth; very graceful. In gal. cans. Each $75 \mathrm{c}$. In 5-gal. cans. Each $\$ 2.00$.

C. verucosus. A much branched shrub, becoming very dense. Small dark green foliage, long sprays of white flowers. In gal. cans. Each, 75c. In 5-gal. cans. Each, $\$ 2.00$.

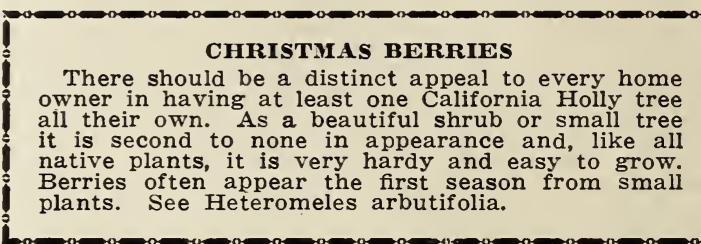

Cephalanthus occidentalis. "Button Bush." "Button Willow." A deciduous shrub found growing along creeks or in wet places. Handsome bright green foliage. Flowers white, fragrant, in spherical heads resembling small pin cushions. In gal. cans. Each, 75c.

Cercis occidentalis. "WVestern Red-bud." Deciduous ghrub, 8 to 12 feet high. Leaves roundish, light green; flowers pea-
cans. Each, $\$ 1.00$.

Cercocarpus betulaefolius. "Mountain Mahogany," A very graceful shrub. Small wrinkled leaves of rich dark green on long reddish colored stems. Does well in either sun or shade and is a fast grower. One of the most valuable of all evergreen shrubs. In gal. cans. Each 75c. In 5-gal. cans. Each $\$ 2.00$.

Chamaecyparis lawsoniana. "Lawson's Cypress." 200 feet. One of the most striking and graceful of all evergreen trees, with horizontally spreading pendulous branches, and flat, compressed foliage: unsurpassed for specimens on lawns. In gal. cans. Each, $75 \mathrm{c}$. In 5-gal. cans. Each, $\$ 2.00$. In tubs, 3 to $4 \mathrm{ft}$., $\$ 3.00 ; 4$ to $5 \mathrm{ft}$., $\$ 4.00 ; 5$ to $6 \mathrm{ft} ., \$ 5.00$.

Clematis ligusticifolia. "Wild Clematis." A deciduous vine with deeply cut foliage and large panicles of small, creamy white flowers, produced in great abundance. The plant is also very attractive later in the season when covered with its large plume-like seed heads. In gal. cans. Each, 50c.

Coreopsis gigantea. "Tree Coreopsis." A peculiar plant with stout trunk 3 to 6 feet high and a few arm-like branches, rich green feathery foliage and yellow daisy-like flowers. In gal. cans. Each, 75c. In 5-gal. cans. Each, $\$ 2.00$.

Cupressus goveniana. "Goven's Dware Cypress." of erect growth forming a handsome crown; rich, dark green foliage. In gal. cans. Each, $50 \mathrm{c}$.

Cupressus macrocarpa. "Monterey Cypress." 70 feet. A splendid tree, extensively planted for hedges and equally valuable for single specimens. The tree equally valuable for single specimens. The tree plants, per flat, $\$ 2.50$. In gal. cans. Each, $50 \mathrm{c}$. In plants, per flat, $\$ 2.50$. In
5-gal. cans. Each, $\$ 2.00$.

Dendromecon rigidum. "Tree Poppy." Graceful willow-like foliage and bright yellow flowers, three inches or more in diameter. Blooms nearly all the inches or more in diameter.

Encelia californica. "Bush Sunflower." Low shrub, valuable for dry banks. Flowers bright vellow with dark brown centers. In gal. cans. Each, 50c.

Eriogonum fasciculatum, "Wild Buckwheat." Low shrub with short needle-like leaves. It is especially valuable for dry banks and flowers in middle of summer. The blossnms are in large heads, white, tinged with pink. In gal. cans. Each $50 \mathrm{c}$.

E. giganteum. "Giant Buckwheat." Native of Catalina Island, grows 3 to 5 feet high. Large silvery gray foliage and large heads of pale pink flowers. In gal. cans. Each, $50 \mathrm{c}$.

Fraxinus dipetala. "Flowering Ash." A deciduous cles. In gal. cans. Each, 75c. 


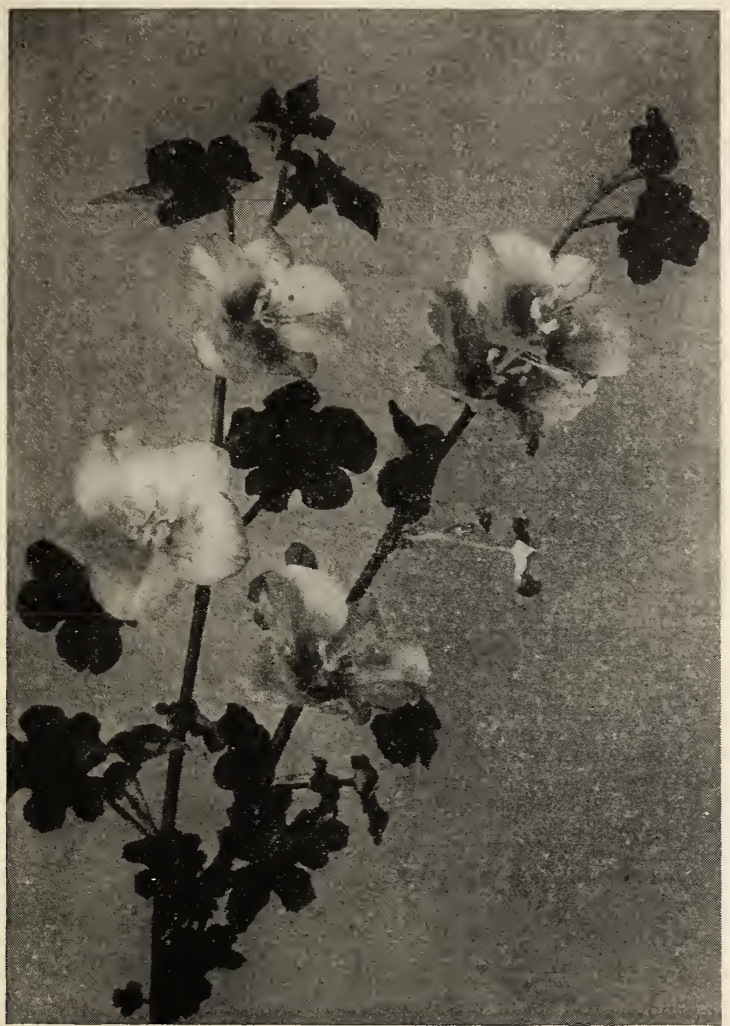

Fremontia mexicana

Fremontia mexicana. Both the flowers and foliage are larger than those of Fremontia californica. The flowers are also a much darker color, being almost orange yellow and are a rich reddish brown on the under side. The seeds are about half the size and jet black. Much more desirable from an ornamental jet black. Much more desirable from an ornamental standpoint. A splendid shrub for a dry hot place.

Garrya elliptica. "Silk Tassel Tree." A handsome shrub; dark leathery leaves. Flowers in long cat-
kins, often a foot long. In gal. cans. Each, 75c.

Gilia californica. "Prickly Phlox." Prickly needlelike leaves, fragrant flowers of delicate rose pink. A handsome shrub. In gal. cans. Each, 75c.

Heteromeles arbutifolia. "California Holly." The well known and much sought for shrub or small tree that produces the beautiful clusters of rich red berries for Christmastime. Equally attractive in foliage it makes an ideal single specimen among
other shrubbery. In gal. cans. Each 75c. In 5-gal. cans. Each, $\$ 2.00$.

Isomeris arborea. "Bladder-pod." Shrub 4 to 8 feet high. Gray-green foliage and yellow flowers. In gal. cans. Each, $75 \mathrm{c}$.

Juglans californica. "California wild Walnut." A beautiful deciduous tree. Small edible nuts. In gal. cans. Each, 75c

Juniperus californica. "California Juniper." A shrub or small tree fof spreading habit, found in dry washes. In the young plants the follage is glaucous but later changes to deep rich green. In gal. cans. Each, 75c. In 5-gal. cans. Each, \$2.00.

Lbocedrus decurrens. "Incense Cedar." Very symmetrical in growth; compact bright green foliage, glaucous underneath, with a pungent yet very pleasing odor. Bark is cinnamon red, forming a very attractive contrast to the foliage. A handsome tree. In gal. cans. Each 75c. In 5-gai. cans. Each \$2.00. Balled, 2 to $3 \mathrm{ft}$, each $\$ 3.00$. Specimens in boxes, $\$ 15.00$ to $\$ 35.00$.

Lonicera subspicata. "Wild Honeysuckle." An evergreen sprawling shrub with rich green foliage and small yellowish-white flowers. Very desirable. In gal. cans. Each, 75c. In 5-gal. cans. Each, \$2.00.
Lavatera assurgentifiora. "Tree Mallow." Shrub, 5 to 12 feet high; flowers deep rose-color with veinings of a darker shade. Of very rapid growth and especially useful for planting on beach sands. In gal. cans. Each, 50c

Lupinus arboreus. "Yellow Tree Luplne." A shrubby species especially valuable for covering dry sandy slopes. It produces great quantities of rich sulphur yellow, fragrant flowers. In gal. cans. Each, 50c.

Lupinus brittoni. "Britton's Bush Lupine." A shrubby species, 4 to 6 feet high. Flowers in long racemes,
rich blue. Very showy and desirable for dry slopes. In gal. cans. Each, 50c.

Lupinus longifolius. .. "Blue Bush Lupine." Very desirable for covering dry, sandy slopes. Flowers abundantly all through the winter and early spring producing a very pretty effect. In gal cans. Each, 50c.

Lupinus Paynei. "Payne's Tree Lupine." It forms large round topped shrubs 4 to 8 feet high from a trunk-like base 3 to 4 inches and sometimes 8 inches in diameter. One large specimen had over 500 flower spikes in bloom at one time. Very handsome silvery green foliage; flowers are produced in racemes 8 to 15 inches long. They remind one of wistaria blossoms and appear in many beautiful shades, some are pale blue, others lavender, pale lilac, dark blue, purple, rose pink, flesh pink or white: all wellow blotch on the standard. blossoms simultaneously. They grow in a heavy blossoms simultaneously. They grow
reddish clay soil. In gal. cans. Each, 50c.

Lyeium richii. "Catalina Box-thorn." A very hand. some shrub with small bright green leaves. Thrives especially. well near the ocean and is useful for covering banks, also makes a good hedge. In gal. cans. Each, 75c. In 5-gal. cans. Each, $\$ 2.00$.

Lyonothamnus floribundus var. asplenifolius. "Catalina Ironwood." A very rare and beautiful tree from the islands off the coast of California. It has beautiful foliage like a fern and large trusses of white blossoms. In gal. cans. Each, $\$ 1.50$. In 5 gal. cans.

Malvastrum fasciculatum. "False Mallow"" Shrub of upright growth, with grey-green foliage and producing in spring immense quantities of small, pale pink blossoms, resembling a single hollyhock. Grows in dry sandy washes. In gal. cans. Each, $75 \mathrm{c}$

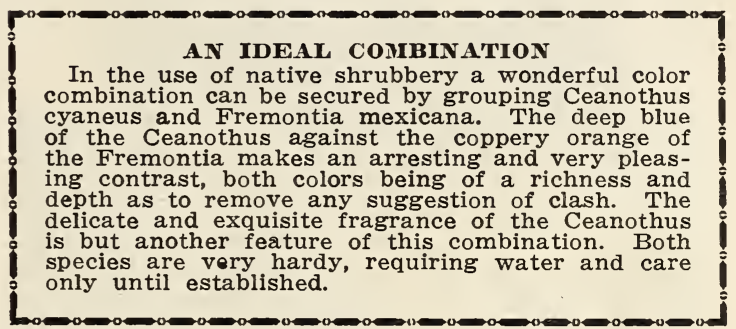

Mimulus glutinosus, "Sticky Monkey Flower." Small shrub 2 to 5 feet high. Flowers buff or salmon-colored resembling an azalea in shape. In gal. cans. Each 50c. Doz. $\$ 5.00$.

Mimulus glutinosus. Brown flowered form. A form nf the preceding. differing only in the color of the flowers, which are mahogany brown. In gal. cans. Each, 50c; doz., $\$ 5.00$.

Mimulus glutinosus. Cream-colored form. Another form of the preceding having cream-colored flowers. In gal. cans. Each, 50c; doz., $\$ 5.00$.

Mimulus puniceus. "Red Sticky Monkey Flower." A species from San Diego county; flowers bright red. In gal. cans. Each, 50c; doz., \$5.00.

Nicotiana glauca. "Tree Tobaceo." Shrub or small tree with handsome glaucous leaves and greenish yellow, tubular flowers. One of the best shrubs for planting in dry places. In gal. cans. Each, $50 \mathrm{c}$.

osmaronia cerasiformis. "Oso Berry." A deciduous shrub with broadly oblong, glabrous leaves. Flowers north slopes; succeeds best in partial shade. In gal. cans. Each, $50 \mathrm{c}$

Pasania densiflora. "Tanbark Oak." A very ornamental tree. In gal. cans. Each, 75c.

Pentstemon antirrhinoides, "Yellow Bush Pentstemon." Very handsome, flowers large, bright jellow. In gal. cans. Each, 50c.

Pentstemon cordifolins, "Scarlet Honejwukle." A woody plant, 6 to 8 leet high, flowers orange scarlet. In gal. cans. Each, 50c. 
Pinus insignis. "Monterey Pine." The fastest growing of all the pines. Foliage a rich vivid green; very symmetrical in growth, pyramid shaped; very hardy. An ideal tree where a quick effect is desired. In gal. cans. Each, 50c. In 5-gal. cans. Each. \$2.00. Very fine specimens in boxes. 5 to $6 \mathrm{ft}$., $\$ 7.50 ; 7$ to $\mathrm{s} \mathrm{ft}$., $\$ 10.00$

Pinus coulteri. "Big Cone Pine." A beautiful tree of perfect symmetry. Foliage full, dark green; growth roundish with a pointed head. One of the best pines for specimen planting. In gal. cans. Each, 75c. In 5 -gal. cans. Each. $\$ 2.00$. Very fine specimens in boxes, 3 to $4 \mathrm{ft}$., $\$ 5.00$.

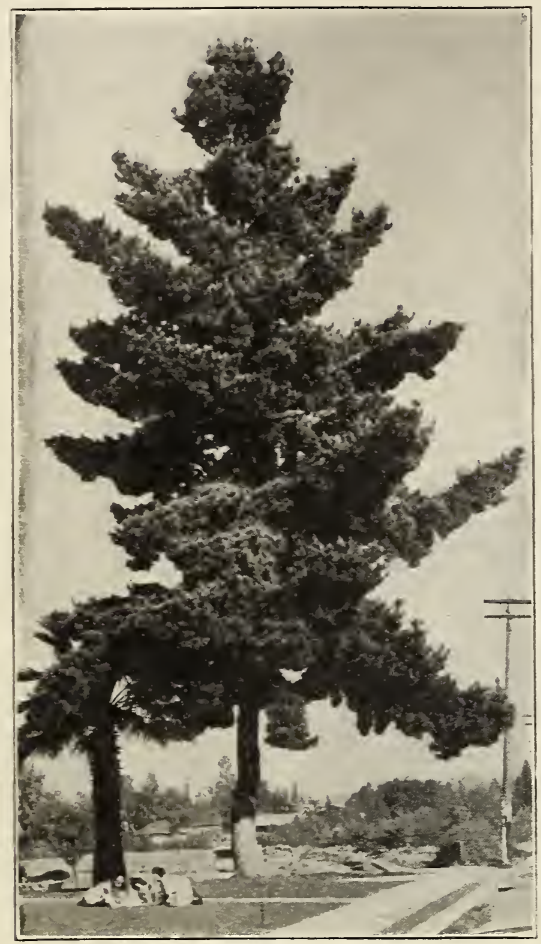

Pinus insignis. "Monterey Pine"

P. muricata. "Bishop Pine." Forms a roundish or flat topped tree from 40 to 80 feet high. Grows best near the coast. In gal. cans. Each, 75c. In 5-gal. cans. Each, $\$ 2.00$. Specimens, boxed, 4 to $5 \mathrm{ft} ., \$ 6.00$ 5 to $7 \mathrm{ft} ., \$ 7.50 ; \mathrm{S}$ to $10 \mathrm{ft} ., \$ 10.00$

P. parryana. "Parry's Nut Pine." A very handsome species from San Diego county. It forms a small tree with rounded top and short needles of a glaucous color. In 5-gal. cans. Each, $\$ 2.50$

Pinus sabiniana. "Sabin's Nut Pine." A handsome tree with gray green or glaucous drooping foliage tree with gray green or glaucous drooping foliage. Of rapid growth and one of the best trees for dry hillsides. In gal. cans. Each. $75 \mathrm{c}$. In $5-\mathrm{gal}$. $\mathrm{cans}$.
Each, $\$ 2.00$. Boxed, 3 to $4 \mathrm{ft.,} \$ 5.00$; 5 to $6 \mathrm{ft}, \$ 7.50$.

P. torreyana, "Torrey Pine." Found on the bluffs at Del Mar, in San Diego County; a rather small tree of spreading habit, needles long and five in a clus-

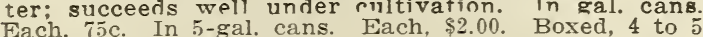
Each, $75 \mathrm{c}$. In 5 -gal. cans.

Pinus tuberculata. (P. attenuata.) "Knob Cone Pine." Very similar to Pinus muricata in growth but a much better tree for a dry location. Foliage formed in tufts; cones oblong. In gal cans. Each, $75 \mathrm{c}$ Boxed, 3 to $4 \mathrm{ft}$., $\$ 5.00 ; 5$ to $6 \mathrm{ft}$. $\$ 7.50$.

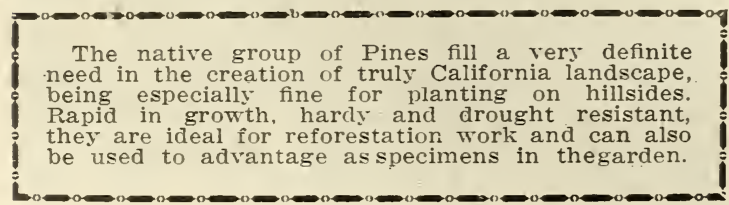

Platanus racemosa. "California sycamore," The most beautiful of all ornamental deciduous trees. Cannot be compared to the European Sycamore. Large leaves; bark becomes white as the tree ages. Equally attractive singly or in groups. In gal. cans. Each ‘c. In 5-gal. cans. Each, $\$ 2.00$. Tubs, 6 to $\mathrm{s} \mathrm{ft}$. each, \$5.00. Bare roots, February and March, 5 to 6 ft., fine specimens, each, $\$ 3.00$.

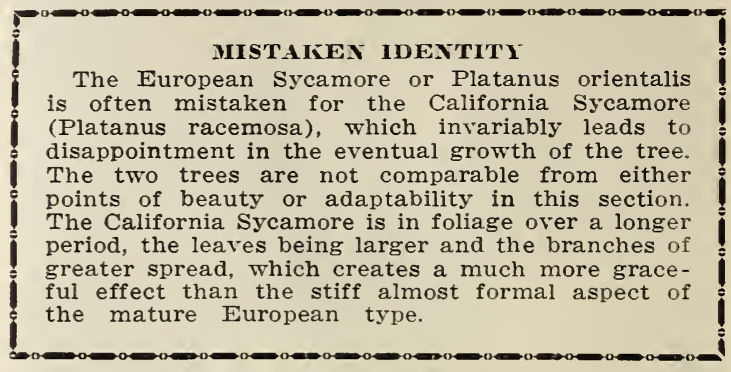

Populus fremonti. "Fremont's Cottonwood." A beautiful deciduous tree with silvery bark. Leaves large, light green. A fine hot weather tree. In gal cans. Each $75 \mathrm{c}$. In 5-gal. cans. Each \$2.00. Bare roots. February and March, 7 to 8 feet. Each, $\$ 2.50$

P. trichocarpa. "Black Cottonwood." Deciduous tree found in many canyons. In gal. cans. Each, $75 \mathrm{c}$ Bare roots, February and March, 7 to 8 feet. Each, $\$ 2.50$.

Potentilla fruticosa. "Shrubby Cinquefoil." A low, much branched shrub with small pinnate leares anu yellow flowers. In gal. cans. Each, $50 \mathrm{c}$.

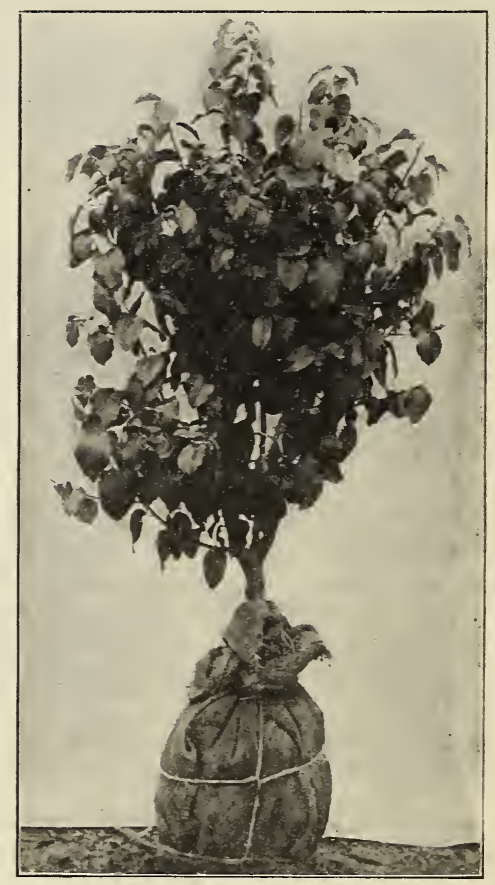

Prunus integrifolia-"Catalina Cherry"

Prunus ilicifolia. "California Wild Cherry." A very attractive shrub or small tree Crinkly dark green leaves, resembling English Holly only smaller, with myriads of cream colored flowers literally covering the plant during spring. Tery striking when planted singly and can be used very attractively as
a hedge. In gal. cans. Each 50c. In 5 gal. cans. Each. $\$ 2.00$.

Prunus integrifolia. "Catalina Cherry." Larger leaves of a lighter green than the California Wild Cherry. Foliage is very glossy, oval in shape and very dense. Particularly attractive when grouped. In gal. cans. Each. 75c. In 5-gal. cans. Each, \$2.00. Boxed, 5 to 6 ft.. fine specimens, $\$ 5.00$. 


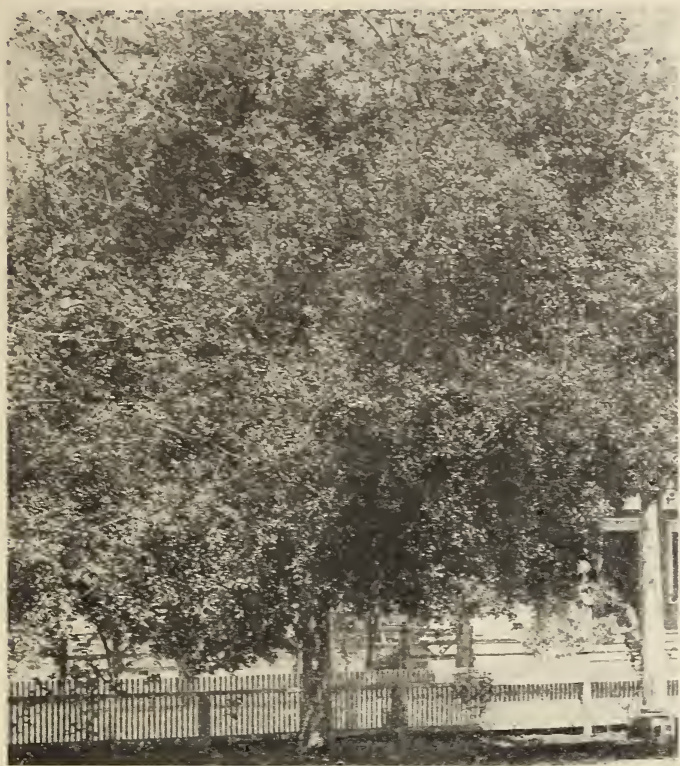

Quercus agrifolia-"Live Oak"

Qnercus agrifolia. "California Live oak." The best known and most admired of all the oaks. Contrary to general belief it is not a slow grower under cultivation. A majestic tree in all stages of its growth and very enduring. In gal. cans. Each 50c. In 5 -gal. cans, $3 \mathrm{ft}$. Each, $\$ 2.00 ; 4$ to 5 feet. Each, $\$ 3.50$. In boxes, 6 to $\delta \mathrm{ft}$, each $\$ 7.50$ to $\$ 12.50$.

Quercus lobata. "Valley Oak," "White Oak," "Roble," Beautiful deciduous tree. with wide spreading and drooping branches. In gal. cans. Each, 50c. Bare

Q. chrysolepis. Golden Cup oak. A very handsome tree with rich green foliage, lighter on the underside. In gal cans. Each, 75c. In 5 gal. cans. Each, $\$ 2.00$.

Q. douglasii. "Blue Oak." A deciduous tree forming a dense rounded crown. Broad, shallow lobed or sometimes deeply lobed leaves: blue green above, paler beneath. In gal. cans. Each, 50c

Q. dumosa. "Scrub Oak." Shrub or small tree, very desirable for dry places. In gal. cans. Each, 50c. In 5-gal. cans. Each, $\$ 1.50$.

Rhamnus californica. "Wild Coffee." A beautiful shrub with rich green foliage. One of the best shrubs for a shady place, also does well in the full sunlight. In gal. cans. Each $75 \mathrm{c}$. In 5 gal. cans.

R. ilicifolla. A handsome shrub, with bright green holly-like foliage, and covered in fall with rich red berries. In gal. cans. Each, 75 . In 5 -gal cans.

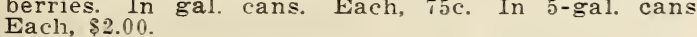

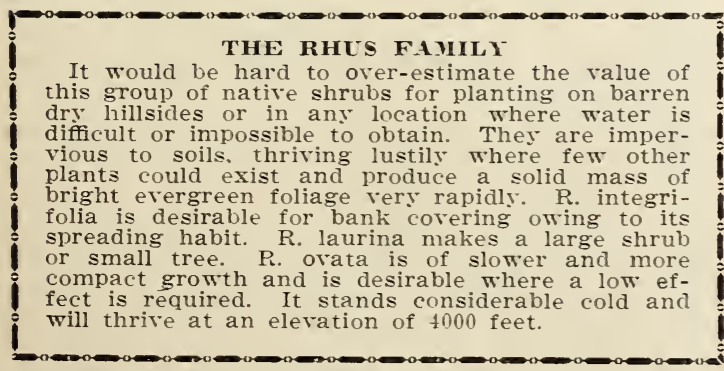

Rhus integrifolia. Cannot be equaled as a permanent bank covering. Leaves thick, slatish green tinged with red, leathery in appearance. A handsome shrub of quick spreading growth; very hardy, requiring water only until established. In gal. cans Each 75c. In 5-gal. cans. Each, $\$ 2.00$

K. laurina. "Sumach." ()f compact form with smooth green foliage and small white flowers Esreciallv valuable for dry places. In gal. cans. Each, 75 c.
In 5 -gal. cans. Each, $\$ 2.00$.
R. ovata. Has large, rich green, leathery follage and forms a oompact growing shrub of great beauty. One of the very best shrubs for a dry place. In ga.

cans. Each. $75 \mathrm{c}$. In 5 -gal. cans. Each, \$2.00.

Rhus trilobata. "Squaw Bush." Deciduous shrub of red in the fall. In gal. cans. Each.

Ribes malvaceum, "Pink Flowering Currant." A very pretty shrub, with pale pink flowers appearing from late fall to spring. In gal. cans. Each, $75 \mathrm{c}$. In gal. cans. Each, \$2.00.

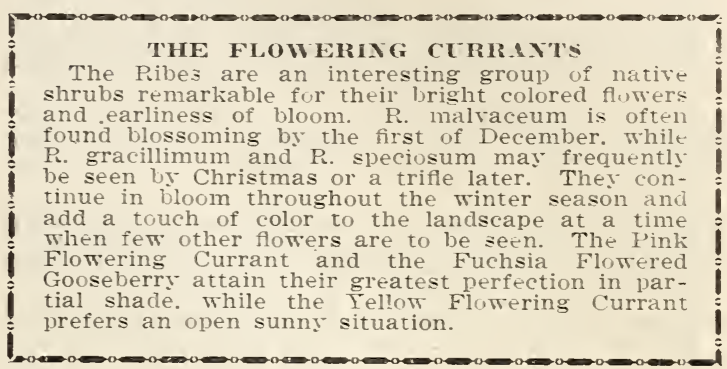

Ribes gracillinum. "Yellow Flowering Currant."

small shrub which sends up root making quite a large clump. root, making quite a large clump. From midwinter to spring it is covered with a perfect shower fruit which make excellent jelly. In gal. cans. Each $50 \mathrm{c}$ In 5 -gal. cans, each $\$ 2.00$. Balled, fin specimens. 2 to $3 \mathrm{ft}$. each, $\$ 2.50$.

Ribes nevadense. "Wild Black Currant." Shrub with small, deep pink flowers followed by black edible
fruits. In gal. cans. Each, $75 \mathrm{c}$. In 5 -gal. cans. Each, $\$ 2.00$.

H. speciosum, "Fuchsia-flowered Gooseberry." Large cardinal red flowers resembling a fuschia In gal. cans. Each, 75c. Balled. 2 to $3 \mathrm{ft}$.. each. \$2.50.

Romneya coulteri, "Yatilija Poppy." White, crepe-like flowers with yellow centers. Strong plants in gal. cans. Each, \$1.00. In j-gal. cans. Each, \$2.5

Rosa ealiforniea. "California Wild Rose." Pink, fragrant flowers appearing until past midsummer. Thrives especially well in heavy soil and will grow in the full sun or in shade. In gal. cans. Each, 50c.

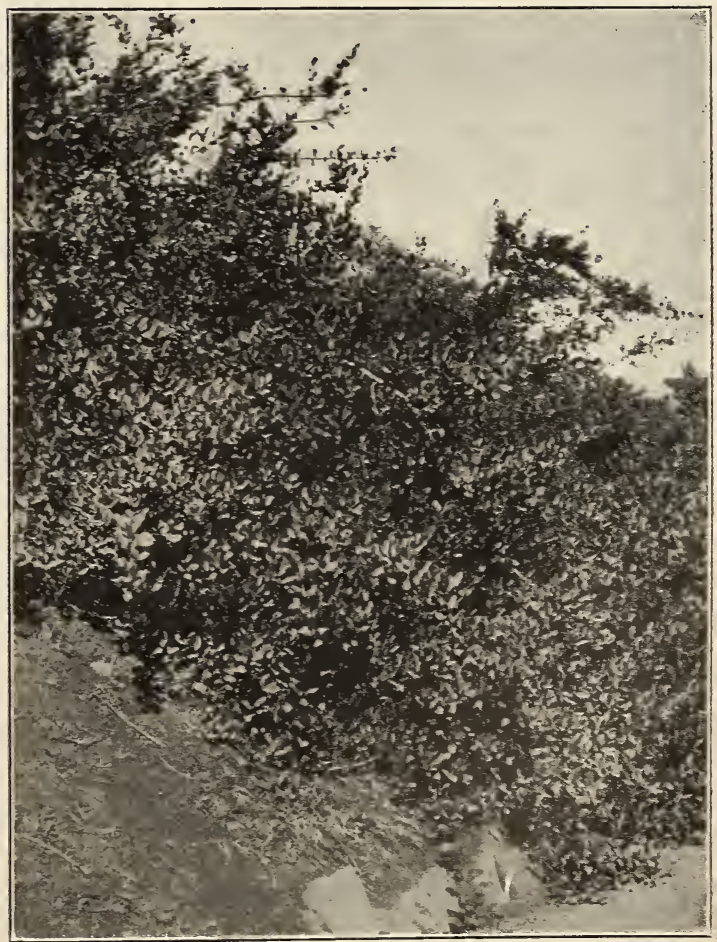

Bank covered with Rhus integrifolia 
Sambucu glauca. "California Elder." A declduous tree but coming out into leaf very early in sprins. Beautiful light green foliage and clusters of creamy Beautiful light green foliage and clusters of creamy
white flowers. In gal. cans. Each, 75c. In 5-gal. cans. white flower
Each, $\$ 2.00$.

Sequola gigantea. "California Big Tree." The monarch of them all. A magnificent tree of perfect arch of them all. A magnificent tree of perfect pyramidal growth. Foliage bluish green; very attractive. In gal. cans. Each 75c. Balled, 118 to 2 attractive. In gal. cans. Each, $75 \mathrm{c}$. Boxed, 2 to 3
perfect specimens, each, $\$ 6.00 ; 3$ to $4 \mathrm{ft}$., each, $\$ 7.50$.

Sequoia sempervirens. "California Redwood." A very ornamental tree of fairly rapid growth. Foliage rich dark green, fern-like and graceful. Very symmetrical; ideal for specimen planting. In gal. cans. Each $75 \mathrm{c}$. In 5 -gal. cans. Each $\$ 2.00$. Specimens in boxes, 5 to $6 \mathrm{ft}$., $\$ 1.00$ per foot.

Solanum xanti. "Violet Nightshade." Flowers deep violet. Very attractive in masses. In gal. cans. Each, 50c.

Sphaeralcea ambigua. "Desert Mallow." A shrubby plant from the Mojave Desert. Grayish-green foliage; flowers salmon buff, very showy and free nowering. In gal. cans. Each, 50c.

Symphoricarpos mollis. "Dwarf Snowberry." A low growing deciduous shrub which likes a shady place In gal. cans. Each, $50 \mathrm{c}$.
Symphoricarpos racemosus. "Snowberry." Similar to the preceding but taller. In gal. cans. Each, 50c

Trichostenia lanatum. "Romero" or "Woolly Bluecurls." Shrub 4 to 6 feet high. Flowers blue, in spikes often a foot long and the whole inflorescence clothed with a dense violet colored wool. Grows in dry places. In gal. cans. Each, 75c.

Torreya californica. "California Nutmeg." A beautiful tree, somewhat resembling the English Yew in to 3 inches long, dark shining green. In gal. cans. to 3 inches long, dark shining green.
Each, $\$ 1.50$. In 5-gal. cans. Each, $\$ 5.00$.

Umbellu laria californica. "California Laurel" or "Bay." A handsome tree with shining dark green foliage. In gal. cans. Each, 75c. In 5-gal. cans. Each, $\$ 3.00$. Boxed, 4 to 5 feet, $\$ 5.00$; 5 to 7 feet, $\$ 7.50$

Vitis girdiana. "California Wild Grape." A beautiful vine of rapid growth, large handsome foliage. Deciduous. In gal. cans. Each, 75c.

Yucea brevifolia. "Joshua Tree." A peculiar plant with stout trunk and open crown of arm-like branches; greenish white flowers. Adapted to hot, dry locations. In gal. cans. Each $75 \mathrm{c}$.

Yucea Whipplei. "Spanish Bayonet." Leaves narrow, glaucous green. Flowers borne on stalk 8 to 15 feet high with as many as six thousand flowers on a single stalk. Flowers pendulous, creamy white and of waxy app

\section{California Native Perennial Plants}

In carrying out a naturalistic effect or for filling in odd corners the following list of native perennials and ferns form a very necessary and interesting addition to an otherwise commonplace treatment. They are free flowering, hardy and require a minimum of care after their establishment. The ferns are particularly attractive when planted under trees or when used in rockeries.

Aquilegia pubescens. "Alpine Columbine." Found in rocky places above 9000 feet elevation. Flowers creamy yellow. In 3 -inch pots. Each, $35 \mathrm{c}$.

Aquilegia truncata, "Columbine." Flowers deep scarlet tipped with yellow. In $21 / 2-i n c h$ pots, each, 20c; doz., $\$ 2.00$.

Aspidium rigidum var. argatum. "Callfornia Wood Fern." Beautiful fern of easy culture, fronds light green 10 to 18 inches long. In gal. cans. Each, 50c.

Avter hesperius. "Wild Aster." Flowers pale lavender. Prefers a moist place. In pots, each 15c; doz., $\$ 1.50$

Audibertia grandifiora. "Humming Bird Sage." A stout growing plant with large leaves and spikes of red flowers. Prefers a shaăy situation. In gal. cans. Each, 50c; doz., $\$ 5.00$.

Cirsium coulteri. "Scarlet Thistle." Biennial, 5 to 8 feet high. Flowers crimson-scarlet. In gal. cans. Each, 50c.

Coreopsis maritima, "Sea Dahlia." Large flowers, 3 to 4 inches in diameter, light canary yellow. In 3 inch pots. Each 20c; doz. \$2.00.

Dicentra formosa, "Pink Bleeding Heart." A graceful plant with finely cut foliage and pink flowers. Very desirable for shady places. In gal. cans. Each, 50c; doz., $\$ 5.00$.

Erysimum suffrutescens. "Beach Wallfower." A much branched woody plant 1 to 2 feet high, found on the sand dunes along the coast. Flowers cream-colored or light yellow. In 2-inch pots. Each, 20c; doz., \$2.00.

Fragaria californica, "Callfornia Wild Strawberry." Valuable as a ground cover, especially under trees. In $2 \frac{1}{2}$ inch pots. Per doz. $75 \mathrm{c} ; 100, \$ 5.00$.

Fragaria chlloensis. "Sand Strawberry." Glossy green leaves and white flowers. Valuable as a ground cover. In $21 / 2$ inch pots. Per doz., $75 \mathrm{c} ; 100, \$ 5.00$

Iris missouriensis. "Western Blue Flag." Grows 10 to 20 inches high; flowers pale blue and white. Prefers a moist situation. Clumps. Each, $50 \mathrm{c}$.

Lathyrus splendens. "Pride of California." A climbing pea; flowers large, deep rich crimson. In gal. cans. Each. $50 \mathrm{c}$.

Linum lewisil. "Blue Flax." Grows 1 to 2 feet high from a woody base. Flowers large, sky blue. In 3 inch pots. Each, 25c; doz., \$2.50.

Lupinus cytisoides, "Canyon Lupine." A magnificent species, often growing 6 feet high or more. It has large, handsome follage and very long racemes of deep pink or rose-purple flowers. Grows in molst places. In gal. cans. Each, $50 \mathrm{c}$.
Micromeria chamissonis. "Yerba Buena." A pretty little trailing plant much prized for its fragrance. Very useful as a ground cover under trees. In 3-inch pots. Each, 25c.

Oenothera hookeri. "Yellow Evening Primrose." Biennial, 3 to 6 feet. Flowers large light yellow. Prefers a moist place. In gal. cans. Each, 50c; doz., $\$ 5.00$.

Oenothera trichocalyx. "White Evening Primrose." Biennial, 1 to $1 \frac{1 / 2}{2}$ leet high. Large white flowers, grows in sandy soil. In gal. cans. Each, $50 \mathrm{c}$; doz., $\$ 5.00$.

Palmerella debilis serrata. "Blue Lobelia." Pale blue flowers. Grows in moist places. Each, 20c; doz., \$2.00.

Pentstemon centranthifolius, "Scarlet Bucler." Glaucous foliage, rich vermilion flowers. In gal. cans. Each, 50c; doz., $\$ 5.00$.

Pentstemon heterophyllus, "Violet Beard Tongue." A bushy plant, $1 \frac{1 / 2}{20} 2$ feet high. Flowers trumpetshaped, royal purple. In gal. cans. Each, 50c; doz., $\$ 5.00$.

Pentstemon palmeri, "White Pentstemon." A spreading plant with thick glaucous foliage and larg, flowers, creamy white shaded with pink. In gal. cans. Each, 50c; doz., $\$ 5.00$.

Pentstemon spectabllis, "Blue Pentstemon." A magnificent plant; grows 4 to 7 feet high: flowers large, blue and royal purple. In gal. cans. Each, 50c; doz., $\$ 5.00$.

Pteris aquilina var. lanuginosa. "Bracken" or "Brake Fern." Well known fern of easy culture. In gal. cans. Each, 50c.

Sidalcea malvaeflora. "Wild Hollyhock." "Checker Bloom." The plant throws up several stems from a woody crown. Flowers large, rose pink. In 3-inch pots. Each, 20c; doz., $\$ 2.00$.

Sisyrinchinm bellum. "Blue Eyed Grass." Grows 8 to 15 inches high. Flowers blue with yellow centers. In 3 inch pots. Each, $20 \mathrm{c} ;$ doz., $\$ 2.00$.

Solldago occidentalis. "Western Golden Rod." Large yellow flowers. Thrives best in a wet place. In pots. Each 20c; doz. $\$ 2.00$

Thalictrum polycarpum, "Meadow Rue." Beautiful foliage resembling Maidenhair fern; panicles of yellow green flowers. Prefers a moist, shady place. In 3 inch pots. Each 20c; doz. $\$ 2.00$.

Woodwardia chamissol. "Chain Fern." (W. radicans.) A very beautiful fern of easy culture with graceful fronds 3 to 5 feet long. In 5-gal. cans. Each, $\$ 1.50$.

Zauschneria microphylla. "California Fuchsia." Vivid scarlet, trumpet-shaped flowers. Especially valua. 


\section{Exotic Ornamental Trees and Shrubs}

Varieties in the following list are evergreen unless otherwise noted. All prices are f.o.b. Los Angeles, plus $15 \%$ of the total amount of the order for packing. We do not ship plant orders of less than one dollar.

ABELIA RUPESTRIS. A pretty shrub with spreading drooping branches, small, glossy green leaves and numerous tube-like flowers, pink shaded with white. In favorable locations this shrub will bloom almost the year round, In gal cans, Each, 50c. In 5-gal. cans. Each, $\$ 2.00$. Boxed, fine specimens, each $\$ 2.50$.

ACACIA BAILEYANA. 30 feet. A strikingly beaut1ful tree with glaucous pinnate foliage and covered late in winter with canary-yellow flowers which completely envelop the tree. In gal. cans, 2 to $3 \mathrm{ft}$ Each, 50c. In 5-gal. cans. Each, \$2.00.

A. ARMATA. "Kangaroo Thorn." 10 feet. A spreading shrub, with small yellow flowers, excellent for grouping, also for hedges. In gal. cans. Each, 50c. In 5-gal. cans. Each, \$2.00.

A. CULTRIFORMIS. "Knife-leaved Acacia." 8 feet A pretty shrub, with triangular shaped leaves of a glaucous green color and vellow flowers in g.xillary racemes. In gal. cans. Each, 50c. In 5-gal. cans. Each, $\$ 2.00$

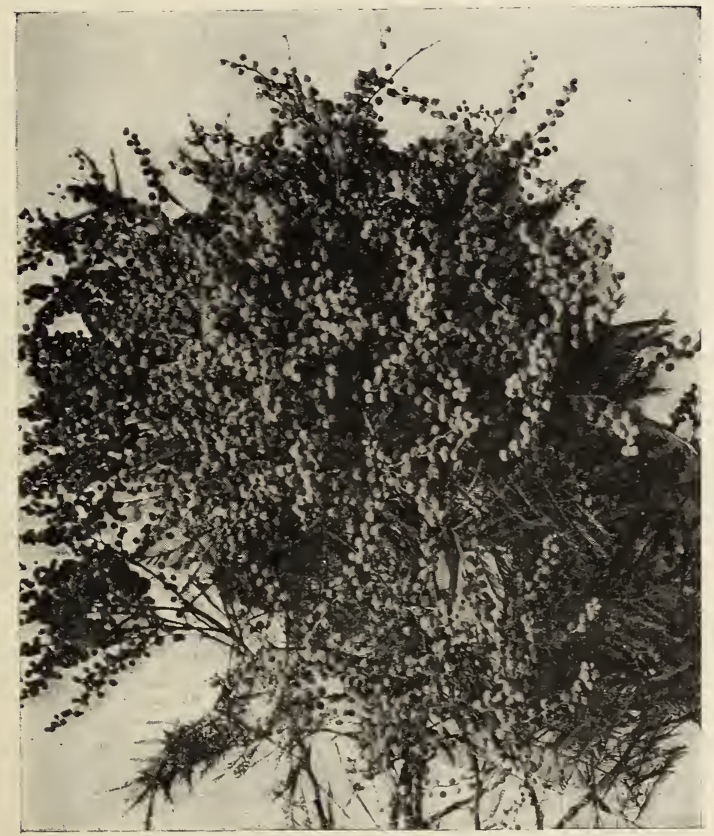

Bloom of Acacia dealbata-"Silver Wattle"

A. DEALBATA. "Silver Wattle." 60 feet. A magniti cent rapid growing tree with glaucous, finely cut cent rapidgrowing tree with glaucous, finely cut follage and covered late in winter with goldenvellow flowers. One of the best for street planting
In gal. cans. Each, 50c. In 5-gal. cans. Each, $\$ 2.00$. A. DECURRENS. "Green Wattle." 75 feet. Finely cut, feathery light green foliage with bright yellow flowers. One of the best for street planting. In gal. cans. Each, 50c. In 5-gal. cans. Each, \$2.00.

A. FLORIBUNDA. (A. nerifolia.) 30 feet. A very quick growing species of pendulous habit, long.
narrow leaves: flowers light vellow. In gal. cans. Each, 50c. In 5-gal. cans. Each, \$2.00.

A. MELANOXYLON. "Blackwood." 75 feet. of compact, pyramidal growth. The favorite tree for street planting Los Angeles. In gal. cans. Each, 50c. In 5-gal. cans. Each, $\$ 2.00$.

A. PENDULA. "Weeping Myall." A rare and beautiful tree, with weeping branches, narrow silvery gray Each, 75c. In 5-gal. cans. Each, \$2.00.

A. PODALYRIAEFOLIA. A very rare and beautiful shrub, somewhat similar to $A$ cultriformis, but with larger leaves and larger fiovers whlch are produced in immense quantities. In gal cans.
ACACIA LONGIFOLIA. "Sydney Golden Wattle." 30 feet. Generally known in California, though wrongIf properly trimmed it makes a fine street tree: also does well near the ocean; leaves long, lanceolate, slussy green. Very free flowering. Catkins of light vellow flowers at the axil of every leaf. In gal. cans. Each, 50c. In 5-gal. cans. Each, $\$ 2.00$.

A. PRUINosa. 25 feet. A very beautiful tree with large, handsome, finely-cut foliage, which is of a rich light green. The young foliage and shoots being of a soft rose color: flowers pale yellow.

A. VERTICILLATA. 12 feet. A shrub of rather spreading habit, with small linear leaves and with flower spikes one inch or less in length: flowers deep yellow and extending the entire length of the youn hranches: on of the best In gal. cans. Each, 50c; 5-gal. cans. Each, \$2.00.

ANGOPHORA LANCEOLATA. A tall spreading tree with clean, smooth bark, much resembling a eucalyptus, to which it is closely related. It is valuable for planting for ornamental purposes as single specimen trees. In gal. cans. Each, 50c.

ARALIA SIEBOLDI. An ideal shade plant. Tery large lobed leaves, usually on grotesque yet artistically formed branches. Creamy white flowers during midwinter. A valuable plant where a tropical effect is RBUTUS UNEDo. "Strawberry Tree." A very desirable shrub with beautiful dark green foliage. In the fall the plants are covered with both blossoms and fruit; the latter in appearance like strawberries. In gal. cans. Each, 75c. In 5-gal. cans. Each, $\$ 2.00$

ARUNDO DONAX. "Giant Reed." Similar in many respects to Bamboo in habit. Rapid grower and fine for a low wind break, thriving with little care or water. Gallon cans, 50c; 5-gallon cans, $\$ 2.00$.

IUCUBA JAPONICA. An ideal evergreen shrub for a shady place. Leaves rather large, bright green with faint markings of yellow, borne on graceful erect shaded corner. Gallon cans, each 75c; 5-gallon cans, $\$ 2.50$.

BAUHinia PURPUREA. 10 feet. Dark green, curiously bilobed leaves. Large reddish-purple and

BERBERIS AQUIFOLIUM. "Oregon Grape." \& leet. A handsome shrub, with shinlng, purplish, prickl leaves and hright yellow flowers, followed by blie or nearly black berries. In gal. cans. Each, $75 \mathrm{c}$ Balled. Each, \$2.50.

B. DARWINI. 3 feet. A beautiful shrub with man slender branches, drooping towards the ends. The follage is dark green and prickly, somewhat like holly, and often turng a bright red in fall, which color it holds through the winter. In early sprin the plants are covered with $q$ profusion of golden yellow flowers. In gal. cans. Each, $50 \mathrm{c}$.

B. WILSONAE. A valuable shrub of late introduction. The plants form low, dense, spreading shrubs, often only a foot or so high, but with several feet of spread, completely covering the ground with a dense mass of small, bright green foliage, which turns to a reddish brown in fall. The flowers are in clusters, reddish brown in fall. The flowers are in cluster", ries. In gal. cans. Each, 50c.

BUDDLEYA ASIATICA. A tall shrub with spreading and slightly drooping branches, producing large terminal spikes of small, white, deliciously fragrant minal spikes of small, white, dellciously fragrant flowers. A splendid shrub for planting as a background for smaller shrubs and flowers.
cans. Each, 50c. In 5-gal. cans. Each, $\$ 2.00$.

BUDDLEYA MAGNIFICA. Similar to B. asiatica, only larger foliage and large spikes of purple flowers. In
gal. cans. Each, $50 \mathrm{c}$. In 5 -gal. cans. Each, $\$ 2.00$.

CALLISTEMON LANCEOLATUS. A very pretty shrub, lanceolate leaves $1 \frac{1 / 2}{\text { to } 21 / 2}$ inches long, reddish when young. Bright red flowers born on spikes. when young. Bright

CALLISTEMON RIGIDUS. "Bottle Brush." A beautiful shrub, with large red, brush-like flowers. Very hardy and especially valuable for dry places. Gal. cans. Each, 50c. 


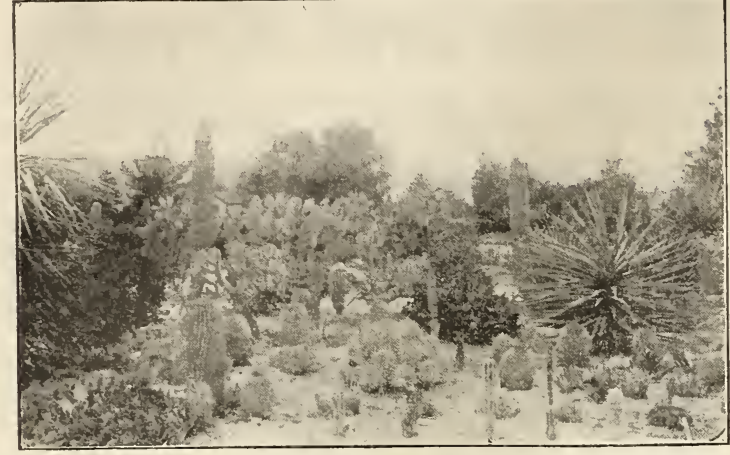

Cactus Garden

C.TCLS. For making a cactus garden or for creating an atmospheric effect in the spanish type of home, varieties, in pots, each $50 \mathrm{c}$; in gallon cans, each $75 \mathrm{c}$ in tubs, each $\$ 2.50$ to $\$ 5.00$. Large specimens of spineless cactus, balled $11 / 2$ to 2 feet, each $\$ 2.50 ; 2$ to 3 feet,

CAMPHORA OFFICINALIS. "Camphor Tree." Chin: and Japan. 40 feet. A very ornamental, symmetri cal growing tree, with bright green, glossy leaves the young foliage being of a pleasing delicate rose Well adapted for lawns or for street plan+ color. Well adapted for lawns or for street plant cans. Each, $\$ 2.00$.

CARISSA GRANDIFLORA. A very handsome shruk w1th glossy green follage and fragrant blossoms followed by large, red, edible fruits. In gal. cans. Each, 75c.

CASSIA ARTEMisioides. Central Australia. A pretty shrub, with finely cut sllvery gray follage and amount of drought. In gal. cans. Each, $75 \mathrm{c}$.

CASSIA MAGNIFICA. A summer blooming shrub. Pinnate leaves: showy flowers of bright yellow very large. Does best in a sunny exposure. In gal. very large.

CASSIA NAIROBENSIS. A handsome shrub of recent introduction. Of low spreading habit, large, rich green, pinnate leaves and immense trusses of large orange-yellow flowers. In gal. cans. Each, $50 \mathrm{c}$. In 5 gal. cans. Each, $\$ 2.00$.

C. TOMENTOSA. Mezico. A quick growing shrui with bright yellow flowers, blooming all through the winter. Very effective. In gal. cans. Each, $50 \mathrm{c}$.

CASUARINA STRICTA. "She Oak." Attaining helght of about 75 feet. Of rapld growth, forming a handsome tree, and particularly valuable for plant ing along roadsides. In cans, $3 \mathrm{ft}$. Each, $50 \mathrm{c}$.

CEDRUS DEODARA. "Himalayan Cedar." 120 feet. One of the most handsome trees in cultivation, succeeding most remarkably.well in California. DroopIng branches and silvery green foliage. In gal. cans. Ing 2 to 3 ft. $\$ 3.00 ; 4$ to 5 ft., $\$ 3.50 ; 5$ to $6 \mathrm{ft}$., $\$ 4.00$. Large specimens in boxes, write for prices.

CERATONIA SILIQUA. "St. John's Bread," or “Caro। Tree." 40 feet. A thick-growing tree with masse: of dark green follage. Will grow in any soll an thrives with scarcely any water. In gal. cans, 2 to

CHAMAEROPS EXCELSA. "Windmill Palm." Finely cut fan-shaped leaves, making a very artistic head on a shapely rather small trunk. One of the best palms for parkway planting; very hardy and imper-

CHAMAECYPARIS LAWSONIANA. See California Native Trees and Shrubs, page 48.

CHOISYA TERNATA. A pretty shrub with brigh1 green, deeply cut foliage and clusters of white, fra grant flowers. In gal. cans. Each, 75c.

CHORIZEMA ILICIFOLIA. A spreading shrub with long wavy-margined leaves somewhat like holly.
Myriads of small pea-shaped flowers of reddish purple and yellow cover the whole plant in winter and early spring. Unequaled for a low shrubbery effect. Gallon cans. Each, $75 \mathrm{c}$.

CISTUS LADANIFERUS MACUIATUS. "Spotted Rock Rose." A Iree flowering shrub of low spreading hablt. Flowers 3 to 4 inches in diameter, pure white with crimson spot at base of petals. In gal. cans. Each, 50c.
Cocos I'LUMOSA. "Queen Palm." The most popular of all the palms for specimen planting and also for parkways in Southern California A very handsome tree in any locity where severe frosts requires good soil and plenty of water. Gallon cans, each 50c; large specimens, price on application.

COPROSMA BAUEKL. A very handsome low growil, shrub. The leaves are almost round, of a clean, glossy green color and have the appearance of having been varnished. It is especially valuable for ing been varnished. It is especially valuable

CORYNOCARPUS LAEVIGATA. Large shrub or small tree, with large, handsome, glossy green, leathery foliage. In gal. cans. Each, $75 \mathrm{c}$.

CORONILLA GLAUCA. A small shrub with glaucous foliage and quantities of bright yellow pea-shaped flowers. In gal. cans. Each, $50 \mathrm{c}$

COTONEASTER FRANCHETI. A handsome shru with many gracefully arching branches. Foliage medium size, distinctly.downy. Flowers pink, fn! lowed by reddish yellow berries. In gal. cans Each, 50c. In 5-gal. cans. Each, \$2.00.

C. BUXIFOLIA. Much branched and almost prostrate Small, dark green, glossy leaves, large red berries. Very handsome for rock work. In gal. cans. Each, $50 \mathrm{c}$. In 5-gal. cans. Each, $\$ 2.00$

C. HORIZONTALIS. Of low, almost prostrate growth Follage small, turning red in winter. Berries rich red, produced in great quantities. In gal. cans

c. PANosa. Of spreading habit, with many gracefully drooping branches, grey green downy foliage nopred in fall and winter with quantities of bright red berries. In gal. cans. Each, 50c. In 5-gal. cans. Each, $\$ 2.00$.

C. THYMIFOLIA. Dwarf Cotoneaster. Compact growth with small leaves. Berries and flowers small but very attractive. In gal. cans. Each, $75 \mathrm{c}$.

CRAPE MYRTLE. See Lagerstroemia.

CUPRESSUS ARIzONICA. "Arizona Blue Cypress." 70 feet. A tree of great scentc value, and without doubt the most sllvery of all cypresses. It grow quite rapidly and forms a perfect tree, thriving in almost any soll, standing intense heat and much frost. In gal. cans. Each, 50c. In 5-gal. cans. Each, $\$ 200$

C. MACROCARPA. See California Native Trees and Shrubs, page 48 .

C. SEMPERVIRENS, VAR. FASTIGIATA. "Itallan Cypress." 75 feet. A tall, tapering tree with erect branches, growing close and parallel with the trunk. Largely used in formal gardens. In gal. cans. Each, $50 \mathrm{c}$. Balled, 4 to $5 \mathrm{ft}$, each, $\$ 1.50 ; 6$ to $7 \mathrm{ft}$., $\$ 2.50$.

DAPHNE ODORA VARIEGATA. A wonderfully attractive evergreen shrub with variegated foliage and exquisitely fragrant light pink flowers. Very rare but hardy under any normal condition. In tubs, 2 to 3 feet, each $\$ 6.00$.

DIOSMA ALBA. "Breath of Heaven." A favorite shrub of small size, with fine, heath-like, fragrant foliage and small white flowers. In gal. cans. Each, $50 \mathrm{c}$.

DORYANTHES PALMERI. Large leaves 5 to 7 feet long with flower stems 8 to 10 feet high bearing a large thyrsus of deep scarlet flowers. It takes the plants several years to reach the blooming period, but the young plants are very valuable for decnrative pot plants. In 5 -inch pots. Each, $75 \mathrm{c}$.

DRA CAENA DRACO. "Dragon Tree." 50 feet. Form 3 a stout stem crowned with numerous sword-shaped leaves. In gal. cans. Each, $75 \mathrm{c}$.

D. INDIVISA. 30 feet. A decorative plant with long narrow leaves and slender stems. In gal. cans.
Each, 50c. Balled, 4 to $5 \mathrm{ft}$., $\$ 3.00 ; 5$ to $6 \mathrm{ft}$., $\$ 4.00$; Each, 50c. Ball
6 to $7 \mathrm{ft}, \$ 5.00$.

DURANTA PLUMIERI. "Golden Dew Drop." A beautiful shrub with light green follage and large clus. ters of pale blue flowers, followed by bright yellow berries. In gal. cans. Each, $50 \mathrm{c}$.

ERICA MELAN'THERA. 4 feet. A very desirable shrub. In late winter and spring the whole plant is shrub. In late winter and spring the whole plant is literally Each, 50c.

BSCALLONIA ALBA. 10 feet. A beautiful shrub of upright growth; leaves deep, glossy green; flowers upright growth; leaves deep, glossy green; flowers bure white. in large terminal cymes. appearing abun-
dantly in fall and early winter. Gal. 'cans. Each 50c.

c. ROSLA. 10 feet. A very desirable kind. with cunspicuous pink blossoms. In gal. cans. Each, 50c.

6. RUBRA. 6 feet. Of rather compact, fense growth: fiowers dark red. In gal. cans. Each, 50c. 
FURCRAEA GIGANTEA. A beautiful succulent plant, ideally suited for rock gardens or cactus gardens and creates a fine tropical effect. Gallon cans, each $75 \mathrm{c}$

EUCALYPTUS BOTRYOIDES. "Bastard Mahogany or Bangalay." Stately in appearance, leathery green leaves. Rapid growth; fine for shade or windbreak. Gallon cans, 50c; 5 -gallon cans, $\$ 2.00$.

ETCA LYPTUS CITRIODORA. "Lemon Scented Gum." Largely planted for ornamental purposes. Gallon cans, Toc; 5-gallon cans, \$2.00.

E. CонлитA. "Tate Tree." A very handsome tree of spredulng habit, especially valuable for highway planting. Gallon cans, 50c; 5-gallon cans, \$2.00.

E. CORNUTA VAR. LEHMANNI. Of small compact habit, Gallon cans, 50c; 5 -gallon cans, $\$ 2.00$.

E. CORYNOCALYX. "Sugar Gum." One of the hest for planting on dry hillsides. Gallon cans, 50c; 5-gallon cans, $\$ 2.00$

E. ERYTHRONEMA. Forms a large shrub or small tree with light green foliage and large, deep red flowers. In gal. cans. Each, $75 \mathrm{c}$.

E. FICIF OLIA. "Scarlet-flowering Gum." 30 feet very ornamental species, with large leathery leaves bright crimson flowers. Gallon cans, 75c; 5-gallon cans, $\$ 2.00$

E. GLOBULUs. "Blue Gum." A well known tree. I cans, 2 to $3 \mathrm{ft}$, each $35 \mathrm{c}$. In flats of 100 plants, per that $\$ 3.50$.

E. LEUCOXYLON VAR. ROSEA. "Victoria Ironbark." A handsome tree with white bark and quantities of pink flowers. Gallon cans, 75c; 5-gallon cans, \$2.00.

E. POLYANTHEMA. "Red Box." Very ornamental; leaves nearly round with a silvery luster. Small white flowers in clusters. In gal. cans. Each, 50c.

E. PULVERULENTA. Of rather dwarf habit with opposite, glaucous leaves. In gal. cans. Each, 50c.

E. RUDIS. Une of the best for street planting. Larg. $1 \%$ planted in irrigated sections on the deserts. Gallon cans, 50c; 5-gallon cans, \$2.00.

E. SIDEROXYLON VAR. ROSHA. "Red Ironbark." A hanfsome tree with drooping hranches, silvery folf age and deep pink flowers. Gallon cans, 75c; 5-gallon cans, $\$ 2.00$

E. VIMINALIS. "Manna Gam." An exceedingly hanr some tree with long pendulous branches, one of th most picturesque for avenue planting. Gallon cans, $50 \mathrm{c} ; 5$-gallon cans, $\$ 2.00$.

See full descriptions of Eucalyptus on pages $3 \$-39$.

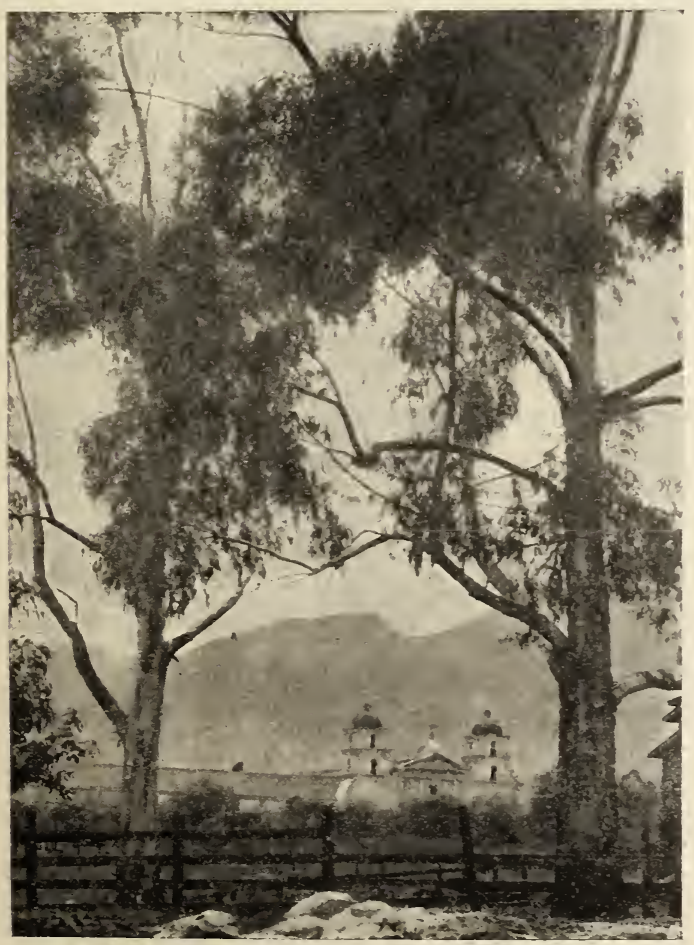

Eucalyotus slobulus-"Blue Gum"

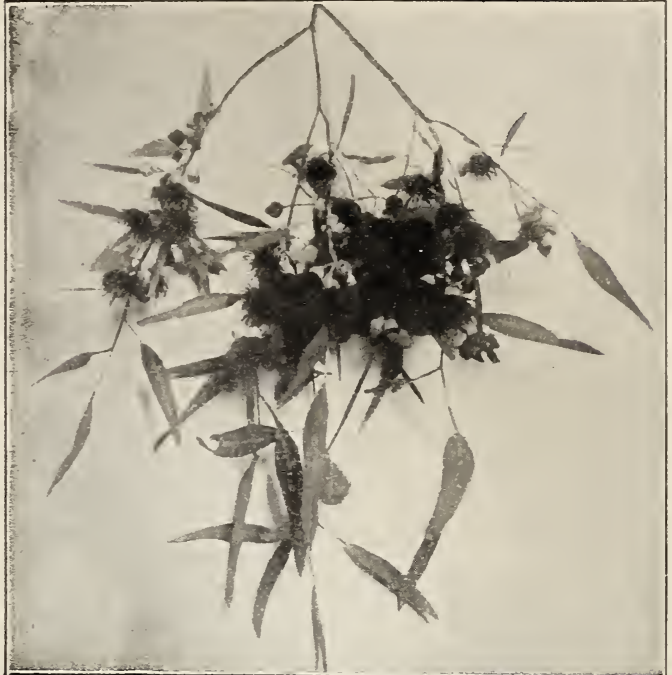

Eucalyptus sideroxylon var. rosea

EUGENIA MYRTIFOLIA. "Australian Brush Cherry." A pretty shrub or small tree. It has small, clean bright glossy-green follage, the young growth often of a reddish color. It is of compact growth, suitable for shrubberies or hedges, or can he trimmed up as a small tree. In gal. cans. Each, 50c; 5-gal. cans, as a

E. HOOKERII. A rare species lately introduced. Foliage similar to the preceding. but larger In gal. cans. Each, 75c. In 5-gal. cans. Each, $\$ 2.00$.

FCCHSIA GRACILIS. A very handsome shrub with rather small attractive foliage and immense quantities of red flowers. In gal. cans. Each, $50 \mathrm{c}$

FUCHSIA MINIMA. Of rather compact growth, leaves small; flowers rose pink produced in great profusion. In gal. cans. Each, $50 \mathrm{c}$

GENISTA CANARIENSIS. A pretty shrub, very effec tive for planting in groups, being covered in sprit with bright yellow flowers. In gal. cans, 2 to $3 \mathrm{ft}$ 5-gal cans.

G. FRAGRANS. (G. ramosissima). Of rather compact growth, covered with bright yellow fragrant flowers. Often grown as a pot plant. In gal. cans. Each, $75 \mathrm{c}$. In 5-gal. cans. Each, $\$ 2.00$

G. MONOSPERMA PENDULA. "Bridal Veil." 10 feet. A rare and handsome shrub with fine, drooping A rare and handsome shrub with fine, drooping. silvery branchlets. The flowers are white and pro-
luced in immense numbers. Gal. cans. Each, 50c.

G. STENOPETALA. Handsome trifoliate foliage; long spikes of large bright yellow flowers. Very ornamental and useful for cutting. In gal. cans. Each, n 5-gal. cans. Each, $\$ 2.00$

GREVILLEA ROBUSTA. "Silky Oak." 150 leet. large tree with pretty fern-l1ke foliage, covered late in spring with orange-colored flowers which are great source of honey for bees; does well in all part. of ralifornia and is one of the most stately trees for avenue planting, thriving with scarcely any wate In gal. cans, 2 to $3 \mathrm{ft}$. Each, 5uc. In 5-gal. cans. Each, $\$ 2.00$

(:. THELEMANNIANA. A beautiful shrub, especially valuable for planting in dry places. It has pretty eathery foliage and produces a great profusion of bright scarlet flowers. In gal. cans. Each, $75 \mathrm{c}$.

HAKEA LAURINA. ( $H$, eucalyptoides.) 10 leet. A winter blooming shrub, with follage similar to the Blackwood Acacia, bearing curious, globose heads of red flowers with white stigmas. In gal, cans. Each, $50 \mathrm{c}$

H. SALIGNA. Of similar habit to the preceding, but has narrower leaves and white finwers. In gal. cans. each, 50c. In 5-gal. cans, each, $\$ 2.00$

H. SUAVEOLENS. ( $H$. pectinata.) A dense shrub at taining a height of 8 to 10 feet, with deeply cut, sharp-pointed leaves and white flowers. In gal. cans. Each, $50 \mathrm{c}$

HELIOTROPIUM. "Heliotrope." An old time favorite. Rather dwarf in habit, with medium sized crinkly dark green foliage and dark purple flowers; rery fragrant. Gallons cans, $75 c$ 


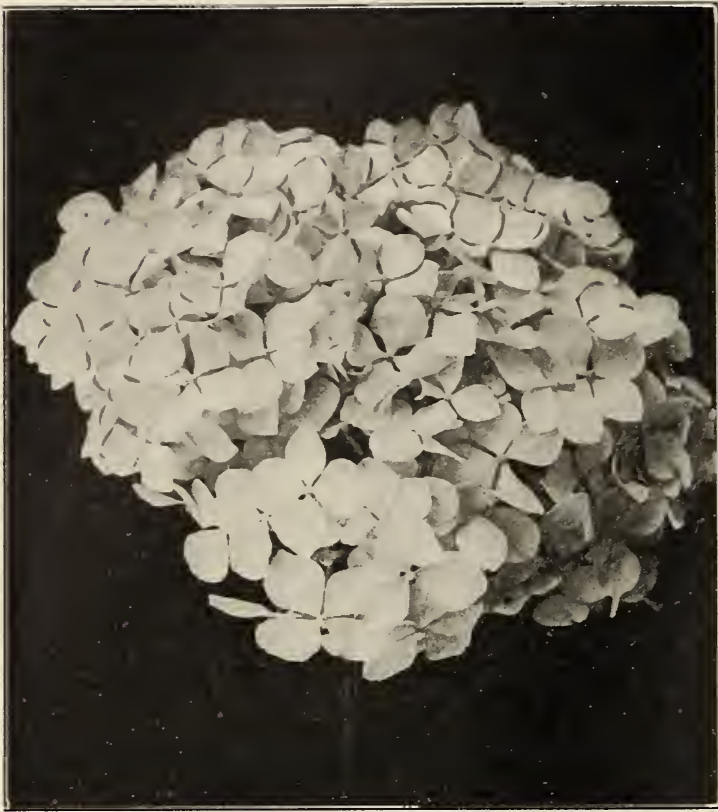

Hydrangea hortensis

HIBISCUS SINENSIS. A lavorite ghrub with brigl green foliage and large, showy flowers. Single rar HIBISCUS SYRACEUS. "Rose of Shaaron." Similar in many respects to the above, with slightly smaller leaves and single flowers. Flowers white with cerise center or lavender with cerise center. One of the cans. Each, $75 \mathrm{c}$. In 5-gal. cans. Each, $\$ 2.00$.

HYDRANGEA HORTENSIS. A well known deciduou: shrub, with large leaves and immense heads of pink flowers. Valuable for 8 mall beds around a porch ol against a wall, continuing in flower nearly all sum. mer. In gal. cans. Each $50 \mathrm{c}$.

JACARANDA MUMOSAFFOHA. (J. ovallfolla.) 30 feet. One of the flnest of our flowering trees, literally covered in early summer with large blue big nonla-like flowers. The foliage is finely cut lik a fern and very pretty. Gallon can
$75 \mathrm{c}$. In 5-gal. cans. Each, $\$ 2.00$.

JACOBINIA CARNEA. Grows 2 to 5 feet high with oblong, tapering leaves. Flowers in large heads, shade. In gal. cans. Each, $50 \mathrm{c}$.

JUNIPERUS PROSTATA. "Dwarf Trailing Juniper." A dwarf trailing variety with handsome glaucous foliage. Very desirable for rock gardens. In gal. cans. Each, $75 \mathrm{c}$.

KERRIA JAPONICA. Sharply toothed bright green leaves. Large double yellow flowers in great quanleaves. Large double yellow flow
tities. In gal. cans. Each, $75 \mathrm{c}$.

LAGERSTROEMIA INDICA ROSEA. "Pink Crape Myrtle." A well known declduous shrub, producin an abundance of showy pink flowers. Each, $\$ 1.50$.

LAGUNARIA PATERSONI, 20 leet. A small pyramidal tree with ovate leaves, whitish underneath. flowers something like Hibiscus, pale rose color. In gal. cans, each, 75c; 5-gal. cans, $\$ 2.00$.

LAURUS CERASUS. "English Laurel." Splendid specimen plants with heavy, thick, glossy foliage. Dense solid growth, creating a vivid spot of bright green wherever used; one of the finest of the evergreen
shrubs. Balled or boxed, 4 to 5 feet, each $\$ 3.50$.

LA URESTMNUS. See Vlburnum.

LEONOTIS LEONURUS. "Lion's Tall." A small shrub blooming abundantly in summer and fall. Flowers in whorls, deep ruddy orange. In gal. cans. Each, $50 \mathrm{c}$.

LEPTOSPERMUM LAEVIGATUM. Th/s beautiful shrub does particularly well in Callfornia and is very valuable for planting in masses, and for alling up odd corners. It grows rapidly and in the spring gal. cans, each 50c. In 5-gal. cans, each $\$ 2.00$.
CIGUSTR UM JAPONICUM. "Japanese Privet." 20 feet. A large shrub or small tree, with glossy, dark green, leathery leaves; often used for hedges and stands
trimming well. In flats of 100 plants, per $100, \$ 2.50$.

L. NEPALENSE. "Small Leaved Privet." 10 leet Much used for hedges in Southern Calleornia. I grows quickly, making a dense, thick hedge. Leaves small, light green, flowers white, in large sprays. In flats of 100 plants, per $100, \$ 2.50$.

MAGNOLIA GRANDIFLORA, 80 feet, One of the finest of American evergreen trees. The leaves are thick, bright green and rusty on the under side: flowers large, waxy white and fragrant. In gal. cans. Each, $75 \mathrm{c}$

MUSA ENSETE. "Abysinnian Banana." Forms a single stout trunk with immense broad leaves 10 to 15 feet long. In 5-gal. cans. Each, $\$ 2.00$.

MYRTUS COMMUNis. "Common Myrtle." Handsome shrub of rather compact growth, with small, glossy green, aromatic leaves. Bears quantitles of small, whlte, fragrant flowers. Valuable elther for single plants for a hedge. In gal cans. Each $50 \mathrm{c}$.

NANDINA DOMESTICA. "Japanese Nandina." A small shrub growing about 5 feet, but increasing by new stalks coming up from the root. The leaves are compound, divided into many small leaflets, very graceful, rich red when young, dark green at maturlty but taking on beautiful coppery tones in winter. Gallon cans, each $50 \mathrm{c}$. Tubs, 2 to $3 \mathrm{ft}$., each $\$ 2.50$. OAK. See Quercus.

OLEANDER. A well known and favorite shrub. Double pink and double white. Gallon cans, each 50c; 5 gallon cans, $\$ 2.00$.

PANICUM PALMHOLIUM. "Palm Grass." Graceful arching spears of rich dark green; very hardy and a vigorous grower. Fine for pools or rockeries, or as a single specimen. Gallon cans, each $50 \mathrm{c}$.

PAPYRUS ANTIQUORUM. "Papyrus." Very fast growing plant, much used around pools and for concealing exposed hydrants. Tall rigid stalks with feathery head. Gallon cans, each 50c; 5-gallon cans, $\$ 2.00$.

PARKINSONIA ACULEATA. Shrub or small tree. 15 to 25 feet. It has thorny, drooping branches, with long, feathery foliage, and showy yellow flowers. In gal. cans. Each, $75 \mathrm{c} ; 5$ gallon cans, $\$ 2.00$.

PEPPER TREE. See Schinus.

PHILADELPHUS MEXICANUS. "Evergteen Mock Orange." Small shrub of somewhat tralling habit. Large white fragrant flowers. In gal. cans. Each, 50c.

PHORMIUM TENAX. "New Zealand Flax." Rigid sword-like leaves from three to six feet long. Flowers yellow with reddish tinge, the whole plant giving a tropical atmosphere for which they are widely used. Gallon cans, each 75c; 5-gallon cans, $\$ 2.00$

PINUS Canariansis. "Blue Pine." 80 feet. A beautiful tree with long pendant needles of a glaucous blue color. It is of rapld growth, stands droughi well and is one of the best pines for Southern California. It has the peculiarlty of sprouting from the stump when cut down or even burned off, which is a valuable feature in the reforesting of our mountains. Gallon cans, each 50c; 5 gallon cans, $\$ 2.00$.

PISTACIA CHINENSIS. "Chinese Pistachio." Round headed symmetrical tree. Very attractive in the fall when the foliage turns a brilliant scarlet. Deciduous. In gal. cans. Each, 50c. In 5-gal. cans. ruary, 5 to 6 feet, $\$ 1.50 ; 6$ to 7 feet, $\$ 2.00$.

PITTOSPORUM EUGENIOIDES. 20 feet. A handsome shrub of upright growth, with light green leaves and dark stems. Very pretty for hedges, also as single specimen plants. Gallon cans, each 50c; 5 gallon cans, $\$ 2.00$.

P. CRASSIFOLIUM. A tall growing shrub, with grey green, downy follage and small deep red flowers. Thrives especially well near the coast. Gallon cans, each $50 \mathrm{c} ; 5$ gallon cans, $\$ 2.00$.

P. NIGRICANS. Shrub of upright growth; small shiny green leaves and dark. almost black stems. In Ral. cans. Gallon cans, each 50c; 5 gallon cans, $\$ 2.00$.

P. PHILLYRAEOIDES. A rare and graceful tree at talning a height of 20 to 25 feet. In hablt and general appearance it resembles the Weeping Willow, but it has the advantage of being an evergreen tree. Gallon cans, each $50 \mathrm{c} ; 5$ gallon cans, $\$ 2.00$.

P. TOBIRA. A handsome ahrub, with dark green shiny leaves and numerous white, fragrant flowers. Gallon cans, each $50 \mathrm{c} ; 5$ gallon cans, $\$ 2.00$

P. UNDULATUM. A shrub or small tree, with large lance-shaped, deop sreen, Eloses lesves and white. fragrant flowers. It makes a splendid hedge and is very handsome as single specimen plants: also euitable for street trees. Gallon cans, each 50c; 5 gallon cans, $\$ 2.00$. 
Platanus oRIkntalis. "European Sycamore." "Orlental Plane." A declduous tree of great beauty. Leaves bright green, deoply cut. It thrives woll in California and is valuable for park and avenue planting. In 5-gal. cans, 5 to $6 \mathrm{ft}$. Each, $\$ 2.00$.

PLUMBago CAPENSIS. Spreading shrub or half climber producing great quantities of sky blue flowers. Gallon cans, each $50 \mathrm{c}$.

podocarpus elongatus. Conlfer. Beautiful dark green foliage. A very fine specimen tree. In gal. cans. Each, $75 \mathrm{c}$.

POPULUS NigRA ITAlicA. "Lombardy Poplar." deciduous tree of tall columnar growth; widely used for sentinel planting at the entrances of drives and in the English type of garden. Rapid growth and hardy: 10 to 12 feet, each $\$ 2.00$.

PRIVET. See Ligustrum.

prunus Caroliniana. "Carollna Cherry." A large shrub or small tree of pyramldal growth, pretty glossy green leaves and white flowers. Makes splendid street tree. Gallon cans, each $50 \mathrm{c} ; 5$ gallon cans, $\$ 2.00$; tubs, 6 to $7 \mathrm{ft}$., $\$ 3.00$.

PUNiCa GRanatum NaNa. "Dware Evergreen Pomegranate." A wonderful little shrub for lining along a drive and can be used as a low hedge. Small bright green foliage with scarlet flowers, followed by brilliant red fruits. Gallon cans, each $50 \mathrm{c}$.

PYRACANTHA ANGUSTIFOLIA. A shrub of upright spreading habit, with small narrow foliage and covered during winter with bright orange colored berries. In gal. cans. Each, 50c. In 5-gal. cans. Each, $\$ 2.00$.

PYRACANTha CRENUlatA. Much branched shrub of rather dense growth; narrow dark green foliage, small deep red berries. Makes a splendid hedge plant. In gal. cans. Each, 50c. In 5-gal. cans. Each, $\$ 1.50$.

PXracantha LALANDI. "Burning Bush." 10 feet A thorny, thick-growing, evergreen shrub, with small dark green leaves and white flowers, folluwed by masses of deep orange-red berries which are particularly attractive, remaining on the plant all winter. In gal. cans. Each, 50c. In 5-gal. cans. Each,

PYRACANTHA YUNNaNeNsis. A desirable shrub lately introduced from Yunnan, China It is of low spreading habit, many of the branches being perfectly prostrate. The foliage is rich dark green, and in fall and winter the plants are literally covered this shrub probably has no equal. In gal. cans Each $_{2} 50 \mathrm{c}$. In 5-gal. cans. Each, \$1.50. Boxed, 5 to 6 feet, $\$ 2.50$.

QUERCUS AGRIFOLIA. "California Live Oak." See page 51.

RAPHIOLEPIS JAPONICA. ( $R$. ovata.) Japan. 12 feet. A beautiful compact shrub of rather slow growth. The leaves are oval, thick and leathery, and of a dark, rich green. In spring the plants are covered with white, fragrant flowers. Gallon cans, each $50 \mathrm{c} ; 5$ gallon cans, $\$ 2.00$.

R. INDICA HYBRIDA. A cross between R. indica and $R$. japonica. A very handsome shrub of rather compact growth with rich green foliage and many large cans, each $50 \mathrm{c} ; 5$ gallon cans, $\$ 2.00$.

ROSMARINUS OFFICINALIS. "Rosemary." A well known and useful shrub. In gal. cans. Each, $50 \mathrm{c}$.

RUSSELLIA ELEGANTISSIMA.... Slender, pendulous branches. Makes an excellent potted plant, being of almost continuous bloom. In gal. cans. Each, $75 \mathrm{c}$

SALIX BABYLONICA. "Weeping Willow." A very picturesque deciduous tree that is ideal for shade in the summer. Long pendulous branches fro
ing crown. 5-gallon cans, each $\$ 2.50$.

SCHINUS MOLLE. "Pepper Tree." 50 peet. The most graceful of our cultivated trees, with its lons graceful of our cultivated trees, with its long coral red berries. It is the admiration of every tour ist who visits our state. Gallon cans, each $50 \mathrm{c} ; 5$ gallon cans, $\$ 2.00$.

SOLANUM RANTONNETI. A very desirable shrub with spreading, drooping branches, small green follage and great quantities of violet-blue flowers. Blooms nearly the year round and requires very little water. Gailon cans, each $75 \mathrm{c}$.

SPARTIUM JUNCEUM. "Spanish Broom." 10 peet. A quick growing shrub, of upright habit. Large, yel low. pea-shaped flowers in great profuslon on roun leafless branches. In gal. cans. Each, 50c. In 5gal cans. Each, $\$ 1.50$.

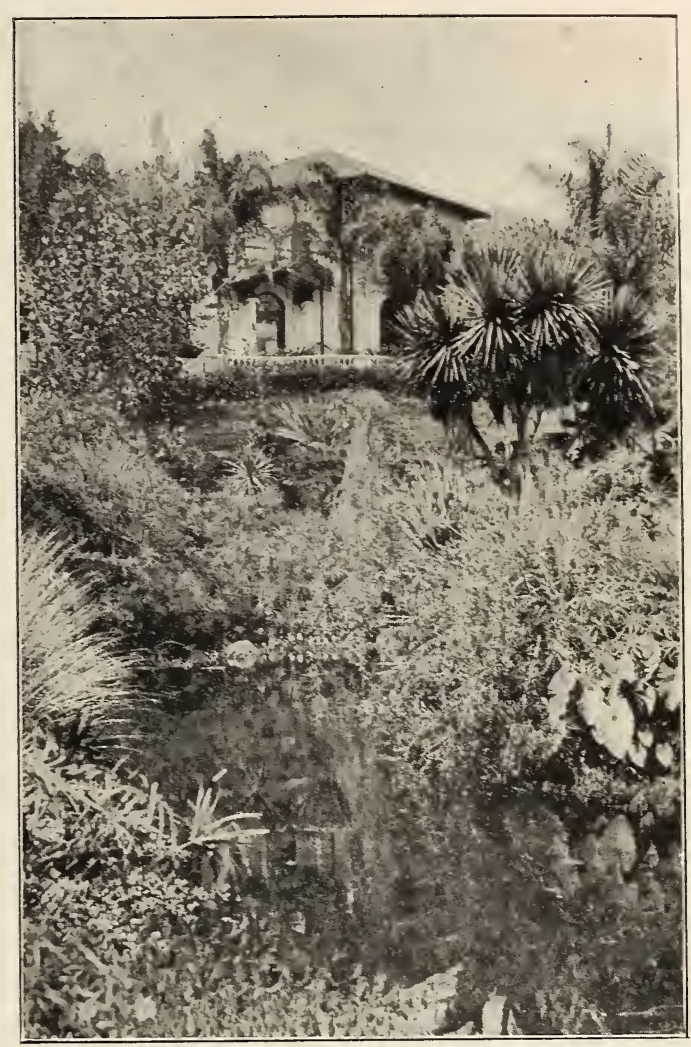

AN ATTRACTIVE GARDEN rarely happens; it is carefully planned. The difference between a well-planted garden and a poorly planted one is often a matter of garden and a poorly planted one is of en a matter of just a little time spent before putting anything in the ground. We have a free planning service that will be proper selection of plants for given effects.

SPIRAEA VAN HOUTTEI. "Bridal Wreath." White flowers borne in clusters on long arching stems. Very attractive deciduous shrub. In gal. cans. Each, $50 \mathrm{c}$.

STREPTOSOLON JAMESONI. A small shrub, particu larly valuable for planting in dry, sunny situations It blooms for a long period, and produces immonos quantities of yello
lon cans, each $50 \mathrm{c}$.

SYRINGA VULGARIS. "Common Lilac." Erect rowing deciduous shrub, bearing purple flowers in large panicles. In 5-gal. cans. Each, $\$ 2.00$.

TECOMA CAPENSIS. "Cape Honeysuckle." Heavy bright green foliage with clusters deep scarlet flowers. as a vine. Evergreen and hardy: a favorite on account of its brilliant coloring. Gallon cans, each $75 \mathrm{c}$.

THUJA ORIENTALIS. (Biota orientalis.) "Chinese Arborvitae." 25 feet. A small thick growing pyramidal tree. Bright green follage turning bronze or brown in the winter. Desirable as single specimen

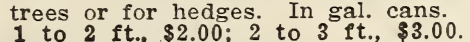

TRISTANIA CONFERTA. "Brisbane Box." A particularly beautiful tree, with large handsome follage and white flowers. It forms a dense compact head and is very ornamental for single specimen trees or for street planting. Gallon cans, each $75 \mathrm{c}$.

VERONICA DECUSSATA. A rather small shrub of foilage bright green; flowers in spikes. violet blue. In gal. cans. Each' $50 \mathrm{c}$.

VIBURNUM OPULIs. "Snowball." Hardy deciduous shrub with many pure white globular flowers in the Gallon cans, each $75 \mathrm{c}$; 5 -gallon cans, $\$ 2.00$.

VIBURN UM TINUS. "Laurestinus." 12 leet. A wellknown shrub with showy umbels of white flowers blooming profusely in the winter. Makes a snlen did hedge. Gallon cans, each $50 \mathrm{c}$ : Jallon cans, $\$ 1.50$ boxed, large specimens, $\$ 2.50$. 


\section{Vines and Trailing Plants}

AMPELOPSIS QUiNQUEFoliA. "Virginia Creeper." Deciduous vine of rapid growth. Large, five parted leaves which turn red in the fall. Gallon cans. Each, $50 \mathrm{c}$.

AMPELOPSIS SEMPERVIRENS. "Evergreen Ampelopsis." A beautiful evergreen vine of slender graceful appearance. Leaves small, divided into 5 leaflets rich dark green. Gallon cans, each $75 \mathrm{c}$.

AMPELOPSIS VEITCHI. (A tricuspidata.) "Boston Ivy. A splendid vine for covering walls, chimneys, stone wnrk or board fences. Glossv green follage, turning to rich shades of yellow and red in the fall. Gallon cans, each $50 \mathrm{c}$.

AUSTRALIAN PEA VINE. (Dolichos lignosus.) A very rapid growing vine, with pretty follage and rose and purple pea-shaped flowers. Valuable for covering up fences quickly: stands the heat well. In 3 -in. pots, each 2 sc; per doz., $\$ 2.50$.

BIGNONIA CHERERE. A magniflcent climber producing large tubular-shaped flowers, hlood red with yellow at the base. Gallon cans, each $75 \mathrm{c}$.

BIGNONIA TWEEDIANA. A very tall growing variety of clinging habit, very useful for covering walls, high plllars, etc. Blooms in snring. large canary yellow trumpet-shaped flowers. Gallon cans, each $75 \mathrm{c}$.

RIGNONIA VENUSTA. Produces large clusters of dee orange, tubular-shaped blossoms. A valuable climber. growing to a great helght: often seen coverin the roofs of houses. Each, $\$ 1.00$.

BIGNONIA VIOLACEA. One of the best evergreen climbers; dark green foliage, glaucous; flowers lavender blue, borne in clusters. Gallon cans, each

BOLGAINTLLEA CRIMSON LAKE. One of the newer introductions. Flowers rich cardinal red. Similar in other respects to the older variety. Gallon cans, each $\$ 2.50$

BUUGAINVILLEA GLABRA SANDERIANA. Blooms when quite young, and is very free flowering; color rich magenta. Gallon cans, each $75 \mathrm{c}$.

CLEMATIS yonTANA. A very desirable vine. Flowers in spring, pure white and fragrant. Gallon cans, ach $50 \mathrm{c}$.

FICUS REPENS. "Climbing Rubber." A splendid vine for covering stone or brick walls, to which it fastens itself tightly by means of aerial roots and makes a dense mat of small. dark green leaves In $2 \frac{1}{4}$-in. pots, each $20 \mathrm{c}$; dozen $\$ 2.00$.

FICUS Mrvm... Similar to the preceding but with smaller foliage. In 3 -inch pots. Each, 50e

HARDENBERGIA COMPTONIANA. (Kennedya comptoniana.) Foliage small, composed of three to five leaflets. Flowers pea-shaped in large clusters, in tense deep violet. An attractive vine flowering abundantly in winter and early spring. Gallon cans. Each, $75 \mathrm{c}$.

HEDERA HELIX. "English IVy." A well-known climber, with large, thick. shining dark green leavoo In $21 / 1$-in. pots, 20c; per doz., $\$ 2.00$. Gallon cans, each

HONEYSUCKLE. See Lonicera.

IPOMOEA LEARI. "Blue Dawnflower." A very rapi grower and a great favorite for covering fences shers. etr. Large blue flowers and rich green fol iage. In 3 -in. nots, each $25 \mathrm{c}$

IVY. See Hedera and Ampelopsis veitchi.

JISMINCY PRIMLLINY. A rapid growing evergreen vine from China, bearing immense quantities of large rich yellow flowers. It blossoms in winte and spring, when the plants are simply covered with

LONICERA HALLIANA. "Hall's Honeysuckle." F'low ers white changing to yellow. very fragrant
splendid vine of rapid growth. Gallon cans, each 50c.

MaNdeyillea SUAveolens. "Chill la $\mathrm{q}$. Large white fragrant flowers. Gallon cans, each 50c.

MUEHLENBECKIA COMPLEXA. "Wire VIne." A rapld growing evergreen vine with wiry stems an small leaves. Desirable for covering fences, trees posts, etc, Gallon cans, each 50c.

PASSIFLORA COERLLEA. "Passion Vine." A rapid growing vine with deeply cut leaves and blue flowers.
POLYGONUM AUBERTI. A very rapid growing vine covered in summer with large panicles of creamy white or flesh-colored flowers. A very spectacular vine in full bloom and one that is universally popular on its sheer merit. Gallon cans, each $75 \mathrm{c}$

SULANDKA GUTTATA. "Coya de Oro." A rare vine of rapid growth, with large, handsome foliage and immense, bowl-shaped, deep yellow flowers. Gallon cans, each $\$ 1.50$.

ULANUM JASMINOIDES. "Potato Vine." A vers rapld growing vine; flowers in clusters. Whlle with yellow centers. Gallon cans, each $50 \mathrm{c}$.

SOLANUM WENDLANDI. Immense clusters of large, light lavender blue flowers; large, glossy, dark gree, foliage. A magnificent plant. Gallon cans, each $\$ 1.00$.

SOLLYA HETEROPHYLLA. "Australian Blue bell, A thick growing vine, useful for covering banks. Dark, glossy green foliage and quantities uf uright blue flowers. Gallon cans, each $75 \mathrm{c}$.

TACSONIA MANICATA. "Scarlet Passion Vine." A splendid climber, producing an abundance of very
large, bright scarlet blossoms. Gallon cans, each $75 \mathrm{c}$.

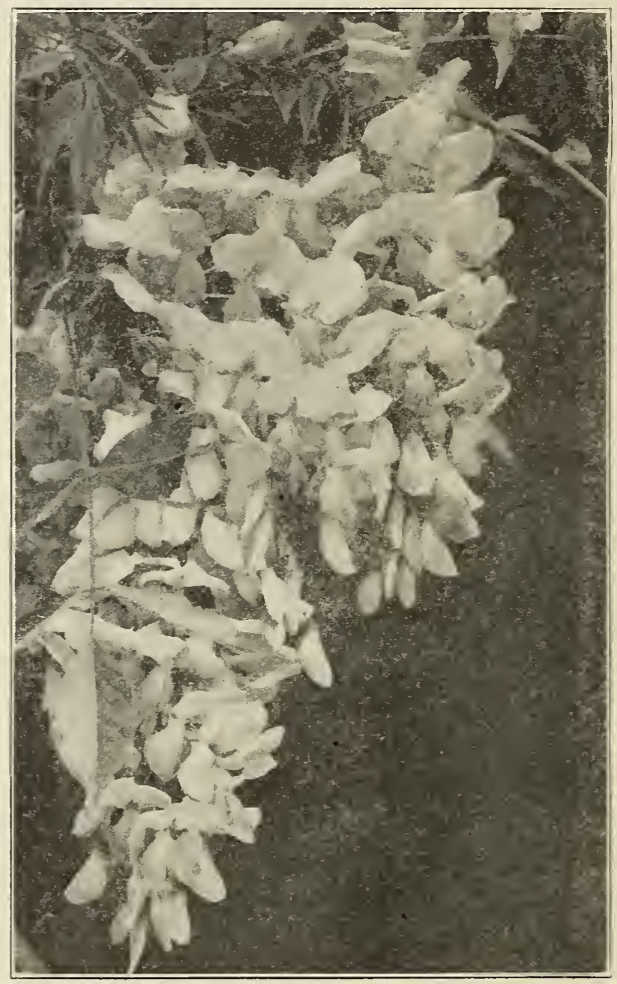

Wisteria chinencis

TECOMA JASMINOIDES. Bright glosgy green follage; flowers white, with purple throat Gallon cans, each ECOMA A USTRALIS. Thick handsume enliag.

ers creamy white, in great profusion. Makes a very attractive effect. Each, $75 \mathrm{c}$

VITIS CAPENSIS. "Evergreen Grape." A rania يrow ing vine, with large handsome foliage. Similar to the fruiting grape. Fine for covering an arbor or pergola. Gallon cans, each $75 \mathrm{c}$.

VINCA MAJOR. "Periwinkle." A fast growing trailing plant: ideal for a ground cover or for planting in window boxes. Evergreen foliage with bright blue flowers. In 21, -inch pots, each $15 \mathrm{c}$; dozen, $\$ 1.50$.

Wis'A IIA CHINENSIS. "Chinese Wistaria "

did, rapid growing climber producing long pendulous clusters of pale blue flowers. Budded, 5 gallon cans, each $\$ 2.5 n$. 


\section{Dahlias}

Dahlias are one of the most popular of the summer flowers owing to their brilliant colors, immense size and universal hardiness. They require a rich soil and plenty of water and should be planted during March and April, at which time the following list of bulbs will be available. Prices are not postpaid; add ten per cent to your order for postage and packing.

\section{Decorative Dahlias}

HALLOWEEN. Buff shading to orange. Perfect stem Fine as a cut flower. Each, $50 \mathrm{c}$.

KITTY DUNLAP. American Beauty rose shading to darker in center. Exquisitely formed flower on upright stem, very large. Each, $\$ 1.00$.

LIBERTY BOND. Flower salmon, tinted rose. Good foliage, upright grower and free bloomer. Each, 75c. IILLIONAIRE. Lavender with shadings of pink. Wonderfully deep bloom. Each, 50c.

MRS. CARL SALSBACH. Rich mauve pink. Flowers well formed on long stems. Each, $50 \mathrm{c}$.

OLD GLORY. Dark red with markings of white. Large flowers, good stem. Each, $75 \mathrm{c}$.

SNOWDRIFT. Beautifully formed flower, pure white, on good stem. One of the best whites. Each, $50 \mathrm{c}$

SOUVENIR GUSTAVE DOAZON. Flowers very large, vivid orange scarlet. Free blooming. Each, $35 \mathrm{c}$.

W. E. COOPER. An exhibition type; mammoth flowers of true pink on long, stiff stems. Each, $\$ 1.00$.

YsLETA. Very desirable shading of buff and bronze Vigorous grower and free bloomer. Each, $50 \mathrm{c}$.

\section{Pompon Dahlias}

ACE OF DIAMONDS. The best scarlet. Each, 35c. DEAREST. Bright rose, silver reverse. Each, $50 \mathrm{c}$ GLOW. Old rose. A very fine flower. Each, $50 \mathrm{c}$

HECKLA. The best white in Pompoms. Each, 35c.

SUNNY DAYBREAK. Yellow edged red. Each $35 \mathrm{c}$

\section{Cactus Dahlias}

CALIFORNA BEA UTY (Hybrid). Deep orange. Very popular for its color. Good stems. Each, 75c.

DADDY BUTLER. (Hybrid) Pink shaded to cream center. Petals twisted. Each, $\$ 1.50$.

GOLDEN WEST. (Hybrid) Chrysanthemum-flowered. Buff shaded orange. Fine for cutting. Each, $35 \mathrm{c}$.

JEAN CHAZOT. A fine French variety. Orange shaded to copper. Perfect stem and foliage. Each, 1.00.

NIBELUNGENHORT (Hybrid). Old rose blending with salmon and apricot. Very free blooming. Each, 50c.

PINK TRIUMPHANT (Hybrid). Rich pink, usually with tiny white tips. Much used in floral work. Each, $\$ 1.50$

F. W. FELLows. One of the best of all known Cactus Dahlias. Deep orange over all. Very large flowers. Each, 75c.

\section{Peony Flowered Dahlias}

CHANSoN. Exquisite shade of purple. Fine for cut flowers. Each, 75c.

MADAM VARD. Currant red shaded to yellow center Each, 50c.

PERRY WIDENER. Large flowers of striking cherry red on strong stems. Each, $75 \mathrm{c}$

VIRGINIA HARSH. One of the largest of the Peony flowered dahilas. Color an exquisite shade of pink. Each, $\$ 1.50$.

THE U. S. A. Deep orange. Long stems and fine flower. Each, $75 \mathrm{c}$

\section{Gladiolus}

Gladiolus bulbs can be planted practically any time of the year, providing an endless succession of flowers. They are very hardy and easy to grow, giving a great return in flowers for little expense and labor. The following list contains many delightful shades of color, including all the newer varieties of proven merit and the most popular of the older sorts. Prices are not postpaid; add ten per cent to your order for postage and packing.

ALICE TIPLADY. Primulinus hybria. New, one of the most beautiful Gladioli ever introduced. Color orange salmon and flame pink, a shade now in great demand in flowers. Excellent for cutting. Each, $15 \mathrm{c}$; doz., $\$ 1.50 ; ; 100, \$ 10.00$.

AMERICA. Soft pink. Each, $10 \mathrm{c} ;$ doz., $80 \mathrm{c} ; 100, \$ 5.00$.

ANNA EBERIUS. Deep velvety purple. Each, 20c; doz., $\$ 2.00 ; 100, \$ 12.00$.

ARLON. Primulinus hybrid. Yellow, shaded with pink and copper, extra fine. Each, $25 \mathrm{c}$; doz., $\$ 2.50 ; 100$, $\$ 15.00$.

BARON HULOT. Violet blue. Each, 15c; doz., $\$ 1.50$; $100, \$ 10.00$.

BYRON L. SHITH. Lavender pink on white ground; color equal to orchid, extra fine. Each, $20 \mathrm{c}$; doz. $\$ 2.00 ; 100, \$ 12.00$.

CRIMSON GLOW. Dark red. Each, 10c; doz., $\$ 1.00$; $100 . \$ 7.00$.

DAVID STARR JORDAN. Flame color overlaid with scarlet, immense flower. Each, $35 \mathrm{c}$; doz., $\$ 3.50$

E. J. SHAYLOR. Deep, rich with ruffled petals. A vigorous grower, producing a tall stem with many flowers open at one time. Each, $10 \mathrm{c}$; doz., $\$ 1.00 ; 100$, $\$ 7.00$.

EVELYN KIRTLAND. Coral pink. Each, 10c; doz., $\$ 1.00 ; 100, \$ 7.00$

GOLDEN MEASURE. Rich yellow, extra fine. Each, $15 \mathrm{c} ;$ doz., $\$ 1.50 ; 100, \$ 10.00$.

HALLEY. Salmon pink. Each, 10c; doz., \$1.00; 100 , IIERADA. Deep mauve. Each, 10c; doz., $\$ 1.00 ; 100$,
$\$ 7.00$.

JACK LONDON. Light samon with orange flame stripes; tall spikes. Each, $25 \mathrm{c}$; doz., $\$ 2.50 ; 100, \$ 15.00$.
E MARECHAL FOCH. Rich pink, very large flowers. Each, 10c; doz., $\$ 1.00 ; 100, \$ 7.00$.

LILY WHITE. Snow white. Each, 10c; doz., $\$ 1.00$; $100, \$ 7.00$.

LOS ANGELES. The most beautiful Gladiolus yet produced. Shrimp pink, tinted orange. The nearest ever-blooming. Each, 50c.

MRS. FRANIK PENDLETON. Salmon pink with blood red blotch on lower petals. Each, 10c; doz., \$1.00; $100, \$ 7.00$.

MRs. H. E. BothIN. Geranium pink with flame scarlet center, distinctly ruffled. Each, $25 \mathrm{c}$; doz., $\$ 2.50$; $100, \$ 15.00$

MARY PICKFORD. Creamy white, throat sulphur yellow. Each, 15c; doz., $\$ 1.50 ; 100, \$ 10.00$.

NORA. Light violet blue. Each, 15c; doz., \$1.50; 100, $\$ 10.00$

PRINCE OF IVALES. Salmon shaded apricot, extra fine. Each, 10c; doz., $\$ 1.00 ; 100, \$ 7.00$

ROSE A.SH. Corinthian-red shading to ashes of roses, lower petals shaded light yellow. Each, 20c; doz., $\$ 2.00 ; 100, \$ 12.00$

ROSE GLORY. Deep rose. Each, 10c; doz., \$1.00; 100, $\$ 7.00$.

VIRGINIA. Glowing scarlet. Each, 10c; doz., $\$ 1.00$; $100, \$ 7.00$.

SUPERB MIXTURE OF ALL SHADES. This mixture will be found very satisfactory where a mass of
mixed color is desired; all first grade bulbs. Each, mixed color is desired; a

PRIMUlinus hyBRIDs. A splendid mixture, mostly in tones running from pale yellow to apricot, buff, pink, and scarlet. The flowers are of good size. pink, and scarlet. The flowers are of good size, slightly hooded, and produced on tall, graceful doz., $80 \mathrm{c}: 100, \$ 5.00$. 


\section{Miscellaneous Flowering Plants and Grasses}

For those who want quick effects in annual and perennial flowering plants the following list offers a wide selection in types of growth and flower. They will produce an abundance of flowers a few short weeks after planting, thereby filling a very important position where an immediate show of color is desired. The annual sorts are seasonable, while the perennials can be supplied at any season of the year.

AGAPANTHUS UMBELLATLS. Blue African Lily." Flower stalks 2 to 3 feet high crowned with large umbels of from 30 to 90 sky blue, lily-like flowere Long glossy evergreen leaves. In gal. cans. Each,

AgATHAEA CoElestis. "Blue Daisy." Perennial. Flowers sky blue with yellow centers. Useful for beds, borders, rock gardens, and window boxes. $\$ 7.50$.

AJUGA REPTANs. Deep blue violet-like flowers on stalks similar to small Hyacinths. Fine ground doz., $\$ 1.00$; per $100, \$ 7.50$.

ALYSSUM SAXATILE. "Gold Dust" Perennial. Excellent for beds and edgings. Flat heads of bright

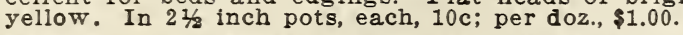

ANEMONE JAPONICA. "Japanese Wind-Flower" White. In 21/2-inch pots. Each, 25c; per doz., \$2.50.

ANTIRRHINUM. "Snapdragons." Perennial. Oldfashioned yet very popular plant. In separate
colors or mixed. In flats. Per doz., 50c; per 100, $\$ 3.00$. AQUILEGIA. "Columbine." Long spurred hybrids. In $21 / 2$-inch pots. Each, 20c; per doz., $\$ 2.00$.

ARENARIA BALEARICA. A remarkable new introduction in Southern California. As a ground cover in to the widely used Helxine and other shade plants. Forms a dense mat of bright green, the leaves being of minute size and the plant only growing an inch or so high. In 4-inch pots. Each, 50c. In flats. Each,

ASTER. Giant Crego and American Beauty Strains. Wonderful assortment of colors; large flowers on long stems. Separate colors or mixed. In flats. Per doz., $50 \mathrm{c}$; per $100, \$ 3.00$.

BEGONIA. Bedding varieties. In flats. Per doz., $75 \mathrm{c}$; per $100, \$ 5.00$

BeLlis PERENNis. "Double Daisy." Mixed colors. In flats. Per doz., 50c; per 100, $\$ 3.00$.

BILBERGLA NUTANs. Numerous slender leaves form the base. Long, drooping, tubular flowers on slender stems, green edged with blue, with bright pink bracts; a peculiar but attractive color combination A splendid subject for a moist shady situation. In 5-inch pots. Each, $75 \mathrm{c}$

CALLA. WHITE. (Richardia Aethlopica.) "Lily of (

CALLA, YELLOW. (Richardia Elliottiana.) One of the finest introductions for many years. Flowers fully as large as the ordinary white varlety, but deep, rich, golden yellow; follage dark green faintly

CALADIUM ESCULENTUM. "Elephantg' Ears." Large, handsome leaves, often 3 feet long by 3 feet wide, very effective on a lawn; requires plenty of water. In gal. cans. Each, 75 .

CALENDCLA, ORANGE KING. Deep orange. Per doz., $50 \mathrm{c} ; 100, \$ 3.00$

CANNAS. "King Humbert." Foliage of enormous size deep purplish bronze shade, with flowers of intense reddish scarlet. One of the most striking of all cannas. In gal. cans. Each, 50c.

CANNAS. "San Diego." Flowers large and of a delightful shade of burnt orange. Bronze foliage. In gal. cans. Each, 50c

CANNAs. Mixed colors. All colors, including red, pink, yellow and scarlet. Each, 20c; per doz., \$2.00.

CARNATIONS. Well known favorite flowers much used for cutting purposes. In red, white, and pink $2 \frac{1}{2}$ inch pots, each, $15 \mathrm{c}$; per doz., $\$ 1.50$.

CENTA UREA CANDIDISSIMA. "Dusty Miller." Silvery foliaged plant for beds and edgings. In $2 \frac{1 / 2}{2}$-inch pots. Each, 10c; per doz., \$1.00.

CHRYSANTHEMUM JAPONICUM. Perennial. Well known plants flowering in the fall and early winter. each, 20c: per doz., $\$ 2.00$

CINERARIA GRANDIFLORA. Large flowered type Its brilliant colors make it easily the most popular of Cinerarias. 4-inch pots, each, $35 \mathrm{c}$; per doz., $\$ 3.50$. Stellata. Very desirable for making a display in feet high with hundreds of star shaped flowers. 4 inch pots, $35 \mathrm{c}$; per doz., $\$ 3.50$.
CONVOLVULUS MAURITANICUS. Perennial trailing plant. Valuable for rock work or hanging basket. Flowers a rich shade of lavender. $2 \frac{1}{2}$ inch pots,
$20 \mathrm{c}$; per doz., $\$ 2.00$.

OREOPSIS LANCEOLATA. Large deep yellow. In CUPHEA HYSOPIFOLIA. A half-hardy perennial. Fine for making permanent border. Flowers small and tubular. 2 inch pots, each, 10c; per doz., \$1.00;

CPERTS Altervifolits. "Lmbrella Plant." Useful for planting around pools. In gal. cans. Each, $75 \mathrm{c}$ In 5-gal. cans. Each, $\$ 2.00$

CYNOGLOSSUM AMABILE. "Chinese Forget-me-not." A beautiful perennial from Southwest China which succeeds well in our climate. The plants grow $11 / 2$ to 2 feet high, producing great quantities of flowers of a true Forget-me-not blue. It makes a splendic display in the garden and is also desirable for cutting purposes. In $2 \frac{1 / 2}{2}$ inch pots. Each, $15 \mathrm{c}$; doz.

DAHLIA IMPERIALIS. "Mexican Tree Dahlia." An unusual and very effective large tree-like plant. In gal. cans, each, $75 \mathrm{c}$.

DELPHINIUM BELLADONNA. A magnificent strain of Delphinium. Flowers are large and arranged rather loosely on the spike, extending out boldly from the main stem. Presents a most graceful $35 \mathrm{c}$; per doz., \$3.50.

DELPHINIUM GOLD MEDAL HYBRIDS. Various shades of blue. Balled. Each, 35c; per doz., \$3.50.

DIANTHUS DELTOIDES. "Maiden Pink." Useful for border 3 and rock gardens, making neat little mats of fine foliage and bearing a profusion of small red flowers. In $21 / 2$-inch pots. Each, $15 \mathrm{c}$; doz., $\$ 1.50$.

DIGITALIS. "Foxglove." An old-fashioned flower with long spikes of tubular flowers; shades of purple, lavender, rose and white. In $2 \frac{1}{2}$ inch pots, each, $15 \mathrm{c}$ : per doz., $\$ 1.50$

ERIGER Ox SPECIOSUS. Free flowering perennial with lavender aster-like flowers. In 3 -inch pots. Each, 20c; doz., $\$ 2.00$.

ELLALI JAPONICA. Ornamental grass with reddish plumes. Useful for planting in the garden or around pools. In gal. cans. Each, 50c.

FESTCCA GLAUCA. A dwarf grass, growing in com pact tufts, steel gray. Useful for edgings. In $21 / 2$ inch pots. Each, $15 \mathrm{c}$; doz., $\$ 1.50$.

GANZANIA SPLENDENS. Large, showy, broadpetaled flowers furnish a constant and brilliant display throughout the summer. In orange and ERANIUMS, IVY IEA VED. All the nomilar kinds.

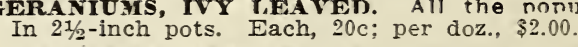

GERANIUMS, SINGLE AND DOUBLF VARIETIES. In $21 / 2$-inch pots. Each, $20 \mathrm{c}$; per doz., $\$ 2.00$.

GERBERA JAMESONI HYBRIDS. Beautifil hroride of the Transvaal Daisy. In gal. cans. Each, 50c; per doz.. $\$ 5.00$.

GEUM, LADY STRATHEDEN. New, double. deep rich yellow. In 3 -inch pots. Each, $10 \mathrm{c}$; doz., $\$ 1.00$.

GEUM, MRS. BRADSHAW. Double, bright scarlet. In 3-inch pots. Each, 10c; per doz., $\$ 1.00$.

HELXINE SOLEIROLII. A delicate little plant with tiny leaves. Grows only an inch or so high and spreads out over the ground making a perfect carpet of green. Very useful for rock work or as a ground cover in moist shady situation
pots. Each, 15c. In flats. each $\$ 3.50$.

HEMEROCALLIS. "Day Lily." Hardy plants, blooming during summer. Large orange and yellow flowers. In gal cans. Each, 50c.

HERBS. We have a fine stock of English Lavender, French Lavender, Garden Sage, Mint, Spearmint, Rosemary, Sweet Marjolam, Thyme and

HOLLYHOCKS. Perennial. A favorite old-fashioned flower blooming in the summer. In mixed colors. $21 / 2$ inch pots, each, $15 \mathrm{c}$; per doz., $\$ 1.50$.

IRIS FIMBRIATA. "Orchid Flowering Iris." A distinct species thriving well in partial shade. Flowers White, pale blue and ye 
IRIS FOETIDISSIMA. "Gladwyn Iris." Often used for planting around pools. The seed pods when ripe burst open showing the bright red seeds which remain on the plant a long time, and are sometimes cut, dried and used for winter boquets. In gal. cans. Each, 50c.

IRIS OCHROLEUCA. A tall growing species, flowers white and yellow. Each, 35c; doz., \$3.50.

LANTANA. Leading varieties. In $2 \frac{1}{2}$ inch pots. Each, $20 \mathrm{c}$; doz., $\$ 2.00$. In gal. cans. Each, $50 \mathrm{c}$.

LANTANA SELLOWIANA. "Trailing Lantana." A rapid growing plant useful as a ground cover in sunny locations. Produces great quantities of lilac colored flowers. In $21 / 2$-inch pots. Each, $20 \mathrm{c}$; doz., $\$ 2.00$.

UIPPIA REPENS. Used for lawns and for covering banks requiring very little water. In flats, \$1.50.

LOBELIA. Crystal Palace Compacta. In flats. Per doz., 50c; per 100, $\$ 3.00$.

LOPEZLA ALBIFLORA. "Mosquito Vine." A pretty little trailing plant desirable for window boxes or as a ground cover. Flowers small, pink tinged with white, produced in immense quantities completely covering the plant. In 3 inch pots. Each, $15 \mathrm{c}$; doz., $\$ 1.50$.

LOTUS PELIORHYNCHUS. A trailing plant with fine, silvery gray foliage and quantities of large, scarlet, pea-shaped flowers. Desirable for hanging baskets, window boxes and rock work. In 3 inch pots. Each, $20 \mathrm{c}$; doz., $\$ 2.00$.

MESEMBRYANTHEMUM. A low ground cover plant with small succulent leaves and deep pink flowers. In $21 / 4$-inch pots, each 15c; dozen, $\$ 1.25$.

MORAEA IRIDIOIDES. A very attractive plant belonging to the Iris family. Flowers large on long stems, white with yellow blotch. In gal. cans. Each, $50 \mathrm{c}$.

MYOSOTIS. "Forget-me-not," Perennial. Bright blue flowers. Does best in a shady, moist location. In 2 -inch pots, each, $10 \mathrm{c}$; per doz., $\$ 1.00$.

NEPETA HEDERACEA. "Ground Ivy." Useful as a ground cover in shady places and for hanging baskets. In 3-inch pots. Each, 20c; doz., \$2.00.

PAMPAS GRASS. Strong plants in gal. cans. Each, 50c. In 5-gal. cans. Each, $\$ 2.00$.

PANSY. Giant mixed. In flats. Per doz., 50c; per 100 , $\$ 3.50$.

PAPAVER NUDICAULE. "Iceland Poppy." Splendid mixture of new art shades. In $2 \frac{1}{2}$-inch pots. Each, $25 \mathrm{c}$; doz., $\$ 2.50$.

PENTSTEMON. Large flowered, mixed colors. In flats. Per doz., 50c; per 100, $\$ 3.50$.

PETUNIA. Double fringed. mixed colors. Sinele fringed, mixed colors. In flats. Per doz., 50c; per 100 , $\$ 3.50$.

PHLOX PEREN NIAL. In separate and mixed colors. In 3-inch pots. Each, 25c; per doz., $\$ 2.50$.

POINSETTIA. Strong plants in gal. cans. Each, 50c. In 5-gal. cans. Each, $\$ 2.00$.

PRIMUla MALACOIDES. One of the most freeflowering varieties of this favorite flower. Very hardy and one of the best winter flowering plants. Flowers a delicate shade of lilac. In 2 inch pots each $10 \mathrm{c}$; per doz., $\$ 1.00$.

REHMANNIA ANGULATA, Pink Perfection. Very desirable for shady places blooming almost continuously. Large trumpet shaped flowers. In 4-inch pots. Each, 35c; doz., \$3.50.

ROCHEA COCCINEA. An attractive succulent with large heads of bright scarlet flowers. In gal. cans. $\mathrm{Each}, 50 \mathrm{c}$.

RUDBECKIA. "Golden Glow." A hardy, fast growing plant with double flowers of a brilliant golden last a long time in water. Strong divisions. In gal. last a long time in water.
cans. Each, 50c; per doz., $\$ 5.00$

SAGINA SUBULATA. A very flne mossy plant ideally adapted to planting in rockeries or between tiles in walks. In flats, each, $\$ 3.50$.

SALVIA LEUCANTHA. "Mexican Bush Sage." A dwarf, shrubby plant; narrow pointed leaves ensurrounded by a brilliant purple calyx. In gal. cans. Each, 50c.

SALVIA SPLENDENS. "Scarlet Sage." Valuable for

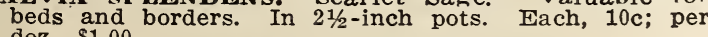
doz., $\$ 1.00$.

SAXIFRAGA CORDIFOLIA. One of the best plants for shady places. Large glossy green leaves and rose pink flowers. In gal. cans. Each, 50c.
SCABIOSA COLUMBARIA. The plants grow 1 1/2 to 2 feet forming bushes often 2 feet across. The flowers are pale lavender 2 to $21 / 2$ inches in diameter and produced in great profusion from early spring to fall. In 3 inch pots. Each, $25 \mathrm{c}$; doz., $\$ 2.50$.

SHASTA DAISY. Alaska, large white. In $2 \frac{1}{2}$ inch pots. Each, 10c; per doz., \$1.00.

STOCKS. Nice Giant. Separate colors or mixed. In flats. Per doz., 50c; per 100, \$3.00.

STATICE PEREZI. Perennial. Small lavender blue flowers produced in pannicles, which can be cut and dried and used for boquets. Deep blue flowers. In dried and used for bog
gal. cans. Each, $50 \mathrm{c}$.

THALICTRUM DIPTEROCARPUM. Beautiful follage resembling maidenhair fern; tall graceful stems with small panicles of lilac blossoms. Very desirable for cutting. In 3 -inch pots. Each, 35c; per doz., $\$ 3.50$.

THUNBERGIA GIBSONI. A trailing plant useful as a ground cover; large brilliant orange colored flowers. In 4 -inch pots. Each, 50c; doz., $\$ 5.00$.

TRITOMA, WM. F. DREER. An improved variety with immense spikes of red and yellow flowers. Clumps. Each, $\$ 1.50$.

TRITOMA GRACILIS. A dwarf growing species with yellow flowers; very free flowering. Clumps. Each, 75c.

VALERIAN. Flower heads are large and of spicy fragrance. Excellent as a border plant and suitable for cutting. Red and pink. In $2 \frac{1}{2}-$ inch pots. Each, $15 \mathrm{c}$; per doz., $\$ 1.50$

VERBENA. Mammoth, separate colors or mixed. In flats. Per doz., 50c; per 100, $\$ 3.50$.

VERBENA ERINOIDES. "Moss Verbena." Perennial of trailing habit with finely cut foliage and great quantities of purple flowers; especially useful for planting in parkings; requires very little water. In $21 / 2$ inch pots. Each, $15 \mathrm{c}$; doz., $\$ 1.50$.

VIOLA CORNUTA. PAPILLIO. Delph blue, very tree flowering, excellent for bedding. In flats. Per doz., $50 \mathrm{c}$; per $100, \$ 3.50$.

violETs. Princess of Wales. Deep blue, large flowers, very fragrant. In $2 \frac{1}{2}$-inch pots, each, 10c; per doz., $\$ 1.00$.

WINTER WALLFLOWER. The flowers are fragrant and come in a great variety of colors, ranging from cream color to primrose, sulphur yellow, golden yellow, lilac, mauve, purple and violet. In $2 \frac{1 / 2}{\mathrm{inch}}$ pots. Each, 20c; doz., $\$ 2.00$.

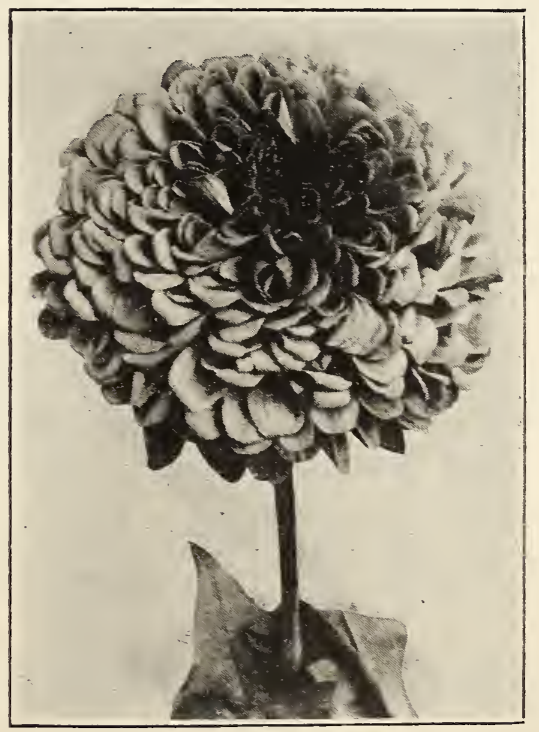

Dahlia Flowered Zinnia

ZINNIAS. Giant Double and Dahlia Flowered in mixed colors. Unequaled for a brilliant show of color during the summer months. In flats. Per doz., 50c; per 100, $\$ 3.50$. 


\section{Fruit Trees for the Home Orchard}

\section{Almonds}

NE PLUS ULTRA. A rapid grower and heavy and regular bearer The nuts are large, very long and soft shelled. Price, each, 75c.

Price, each, 75c. Apples

DELICIOUS. Large, rather conical in form; bright red, splashed lightly with yellow; flesh crisp, sweet and juicy. A good bearer. November.

JONATHAN. Yellow and red, of medium size; flesh rich, tender and juicy. Very productive and a good winter variety. November to December.

WHITE WINTER PEARMAIN. Of medium size, oblong, pale yellow, sprinkled with miniature brown spots; flesh crisp and juicy, with pleasant sub-acid favor $A$ standard market sort. Succeeds well in all parts of the state. November to February.

YELLOW BELLFLOWER. Of large size, oblong, yellow; flesh crisp and juicy, sub-acid flavor. A standard variety in Callfornia and succeeds well in the interior. October to January.

YELLOW NEWTOWN PIPPIN. Golden yellow, large: flesh firm, crisp and juiey. One of the standard varieties in California, and very largely planted. January to March.

\section{Crab Apples}

TRANSCENDENT. Large, yellow striped with red, of pleasant aromatic flavor. A vigorous grower and very productive, the best variety for general use. August.

\section{Apricots}

ROYAL. Medium size, oval, dull yellow, flushed with red. A standard variety. It is a favorite sort for canning and drying; succeeds well in all parts of the state and is more extensively planted than any other state and is more extensivel
variety. Price, each, $75 \mathrm{c}$.

\section{Avocado}

This splendid tropical fruit has attracted much attention of late in Southern California since it has been found that it can be grown successfully in sections where the orange and lemon thrive. It succeeds best in a deep loamy soil and attains a height from 20 to 40 feet. We have found the variety "Fuerte" the best all around fruit for home use.

FUERTE, Considered by many the best Avocado yet introduced. The fruit weighs a trifle under a pound and are smooth and green in color. The flavor is very rich. In the laboratories of the University of California this variety was found to contain 30.72 per cent of fat or oil which places it among the very best varieties for quality. The trees are very hardy, of vigorous growth and come into bearing much sooner than most varieties and produce a very heavy crop. Ripens from January to March. the time of year when Avocados bring the higheot price. Balled, 3 to $4 \mathrm{ft}$., each $\$ 5.00 ; 4$ to $5 \mathrm{ft} ., \$ 7.50$; 5 to $6 \mathrm{ft}$., $\$ 10.00$.

\section{Cherimoyer}

This is one of the finest fruits ever grown and succeeds well in Southern California. The fruit, which ripen in spring, are 3 to 5 inches in diameter, heart-shaped, or a grayish brown color and produced in great abundance. The flesh is a white, melting, custard-like pulp of delicious favor. Grown from seed selected from the largest, free fruiting trees. In gal. cans. Each $75 \mathrm{c}$.
fruit.

\section{Cherries}

ROYAL ANN. Large, pale yellow, richly dotted with deep red and with a bright red cheek; flesh sweet and juicy. A good bearer. Price, each, $75 \mathrm{c}$.

\section{Figs}

KADOTA. A white fig of medium size, rich flavor and one of the best for table use. It is very prolific and the trees bear when quite young.

MISSION. Large dark purple. A good grower and bearer. The large black fig so common in California Price, each $75 \mathrm{c}$.

\section{Lemons}

EUREKA. Medium size; a good keeper; the best for general use. Each, $\$ 2.50$.

\section{Loquats}

CHOICE SEEDLINGS. Grown from seed saved fror choice large fruited varieties. In gal. cans. Each, $50 \mathrm{c}$

\section{Nectarines}

STANWICK. Large, pale greenish white. shaded with rich violet; flesh white, rich and juicy. Price, $75 \mathrm{c}$.

\section{Olives}

ManzaniLLo. Large, purplish black, with light colored specks. One of the best commercial varieties, both for pickling and oil. Price, each $\$ 1.50$.

MISSION. Medium size; deslrable for pickling, either green or ripe; also a good variety for oil. An old standard variety introduced by the Spanish padres and now grown here probably more than any othor sort. Tery attractive as an ornamental tree. Established in 5 gal. cans. Each $\$ 2.00$.

\section{Oranges}

TANGERINE. (Dancy's.) Medium size; very sweet rind thin and separates easily. Each $\$ 3.00$.

VALENCIA, LATE. Large, oblong; ripens very late. Balled, 2 year old. Each, $\$ 2.50$.

WASHINGTON NA VEL. The standard variety in Caliornia. Fruit large. luscious and seenless: g gnod bearer and shipper. Balled, 2 year old. Each, $\$ 2.50$.

Price, each, $75 \mathrm{c}$.

\section{Peaches}

GARLY CRAWFORD. Large, oblong; skin yellow, with red cheek; flesh yellow and sweet. Middle or July.

ELBERTA. Very large; bright yellow, with mottled red cheek; flesh yellow, juicy and sweet. One or the best market varieties. Late in July.

J. H. HALE. Large, highly colored, flesh yellow and of rich flavor. The best peach for general use.

GEORGE THE FOURTH. Fruit large, white, with red cheek; flesh pale, rich and juicy; very popular as a table variety. End of August.

LATE CRAWFORD. Very large, yellow, with dark red cheek; flesh deep yellow, rich flavor. A popular variety for drying and canning.

PHILLIP'S CLING. Large, round, yellow, with slight blush on the sunny side. Flesh firm, clear yellow. A favorite for canning.

Price, each, $75 \mathrm{c}$.

\section{Plums}

BURBANK. Large, red with lilac bloom; flesh deep yellow, very sweet. A strong, vigorous grower; often commences bearing when 2 years old.

KELSEY JAPAN. Very large; green, changing to rich yellow, shaded with reddish purple when ripe and covered with bloom; flesh yellow, firm and sweet: a good bearer. July to October.

SANTA ROSA. Large, oval, purplish crimson with light blue bloom. Flesh pale amber near the stone, shading to deep, purplish crimson near the skin. Regular bearer; valuable for both shipping and home use. For beauty and quality of fruit it is unsurpassed. Early July.

SATSUMA. "Blood Plum." Large, globular, dark red with thin lilac bloom; flesh dark red, firm and julcy. July.

wICKSON. Very large, deep cherry red, changing to rich claret color; flesh amber, rich and juicy. This variety was originated by Mr. Luther Burbank and is a cross between Satsuma and Kelsey Japan, and is considered by him one of the best of the Japan plums.

\section{Pears}

BARTLETT. Large, clear, lemon-yellow with soft blush: flesh white, juicy and rich. The most popular variety. Each, $75 \mathrm{c}$.

\section{Persimmons}

HACHIYA. Large, conical. hright red. Flesh yellow, of highest flavor. Each, $\$ 1.50$.

\section{Pomelo or Grapefruit}

MARSH'S SEEDLESS. Medium size, practically seedess; thin, smooth skin; fine flavor. Each $\$ 2.50$. 


\section{Prunes}

FRENCh PRUNE. Medium size, violet purple: rich and sugary. A standard variety for drying. Each, $75 \mathrm{c}$.

\section{Quinces}

PINEA PPLE. Large, flavor has a suggestion of pineapple; a good bearer. Each, $\$ 75 \mathrm{c}$.

\section{Walnuts}

WUREKA. Nuts large, soft shelled, of fine quality. Blooms late and is especially desirahle for cold sections. Gratted on California Black root, 6 to $\mathrm{s}$ ft. tions. $\$ 2.00$.

- LACENTIA PERFECTION. The standard variety in Southern California. Nuts large, full, white meat. extra fine quality. Trees grafter on Callfornia Black WValnut root, 6 to $8 \mathrm{ft}$., each, $\$ 2.00$.

\section{White Sapote}

Forms a handsome spreading tree, with palmate. glossy green foliage and is extremely drought resistant. The fruit is about the size of a quince and similar in appearance, with thin skin and sweet pulp of a flavor unlike any other fruit.

SEEDLINGS. Grown from seed saved from choice fruit. In gal. cans. Each 50c.

\section{SMALL FRUITS}

An ideal combination of beauty and economy can be secured by a careful selection from the following list. Guavas and Feijoas make handsome evergreen shrubs that are admirably suited for hedges or for covering an ansightly fence; the berried fruits can be grown or ansightly fence, the verried fruits can be grum or ideal covering for pergola or outhouse. Do not overlook the possibilities in the small fruits.

\section{Blackberries}

CORY'S MAMMO'TH THORNLESS. A vigorous grower often making a growth of 20 to 25 feet in one season. The berries are very large, with few seeds, and of delicious flavor. By many considered to be the which is a great advantage. Each $20 \mathrm{c}$; per doz. $\$ 2.00$.

\section{Dewberries}

GARDFNA. Large, glussy hlack; rich flavor, good bearer. Each $15 \mathrm{c}$ : per diz. $\$ 1.50$.

\section{Feijoa or Pineapple Guava}

Fruit delicious, mingling the flavor of the pineapple them will impart a pleasing fragrance in a room. It is an ornamental, glaucous-leaved evergreen shrub and very beautiful when in flower, the blossoms having heavy, waxy petals, pure white beneath and shaded to a purplish crimson on the upper side. Well meriting place in the garden for its flowers alone. Each $50 \mathrm{c}$.

\section{Grapes}

Price, each, 15c; per doz., $\$ 1.50$, unless otherwise noted.

BLACK HAMB URG. Very large bunches; fruts roun and large; flesh sweet and juicy. A fine table grape.

CONCORD. Bunches large ard compact; truits largo round and sweet. Each, $25 \mathrm{c}$; per doz., $\$ 2.50$.

FMPEROR. Bunches very large; irults large, oblong deep rose colored. One of the best late varieties for the market. A strong grower and heavy bearer.

MALAGA. Very large bunches, often weighing 10 pounds; Iruits very large, oval, yellowish green. A good shipping variety, commanding a high price in the eastern markets. The vine is a strong growe and very productive.

MUSCAT OF ALEXANDRIA. Bunches long and loose shouldered; iruits oval, yellowish green, rich flavored. Very largely grown for ralsins.

THOMPSON'S SEEDLESS. Bunches very large; r rult greenish yellow, oval, firm and seedless. A rapid srower and enormous bearer.

\section{Guava}

STHAWBRRY. Fruit round, deep claret color of strawberry flavor. Much used for jellies and preserves; also good for eating in the presh state In gal. cans Fach 50 .

YELLOW STRAWBERRY GUAVA. Similar to the red strawberry guava, except in the color of the fruit which is a bright yellow. Generally conceded to be of finer flavor than the red variety. In $2 \frac{1}{2}-$ in. pots Each, 25c. In sal. cans. Each, $50 \mathrm{c}$

\section{Loganberry}

I,OGAN BERRY. A hybrid between the raspberry and blackberry. Fruit dark red, often $1 \frac{1 / 4}{\text { inches long }}$ and produced in immense clusters. In flavor it partakes of both the raspberry and blackberry, a mild pleasant, vinous flavor, delicious and pecullar to this corrv alone. Fxcellent for the table, fams or jellies. Each 20c; per doz. $\$ 1.50$

\section{Raspberries}

LA FRANCE. The largest fruit of any of the raspberries: fine flavor, heavy wearer. The best for home ise. Each 25c; per doz. $\$ 2.50$

ST. REGIS. The earlicst red raspberry. It begins to ripen in April and continues through the entire berry season. Prolific and of good quality Each. 15c; per doz., 1.50.

\section{Strawberries}

CAROLINA. The new strawberry for California. Very early and will bear a crop 8 to 12 weeks after trans planting. A continuous bearer of fine large red ber ries and dnes hetter in rallfornia than the sn-called everbearing varieties. Per doz. $25 \mathrm{c}$; per $100 \$ 1.75$.

KLONDYKE. Very uniform, rich blood red, juicy and of delicious flavor; medium early. This variety is of recent introduction and is hecoming very popula here. Per doz. $25 \mathrm{c}$; per $100 \$ 1.75$

Books on Gardening
For the amateur or professional gardener the following list of books on gardening will be




\section{Complete Equipment for Garden Maintenance}

We carry a complete line of garden requisites, inclusive of hose, implements, budding knives, pruning shears, sprinklers, watering cans, insecticides and fungicides, and all other equipment necessary to proper maintenance of the garden. We will gladly give information and prices upon request.

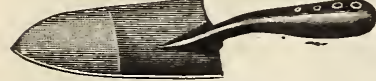

All steel garden trowe1

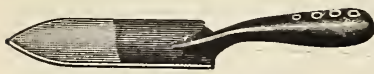

All steel transplanting trowel _... $35 \mathrm{c}$

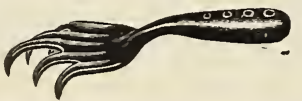

All steel claw weeder

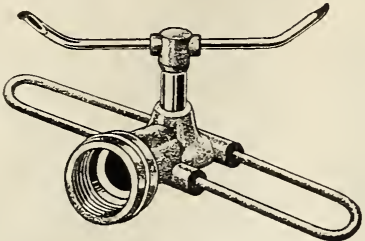

Revolvlng Sprinkler, $\$ 1.25$ each

Note. We stock many different types of sprinklers to meet all requirements. Write for prices requirements.

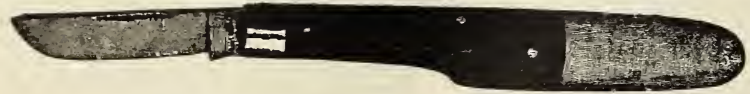

Imported best steel Budding Knives, $\$ 2.25$ each

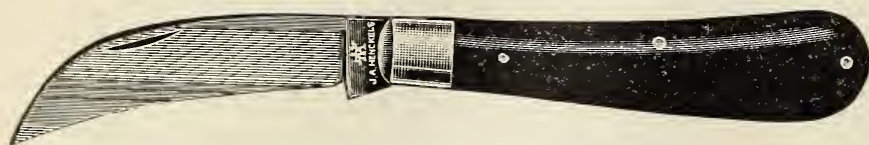

Imported best steel Garden Knives, many sizes, $75 \mathrm{c}$ to $\$ 2.50$

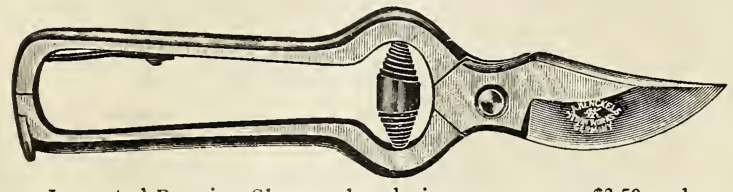

Imported Pruning Shears-handy in many ways $-\$ 2.50$ each

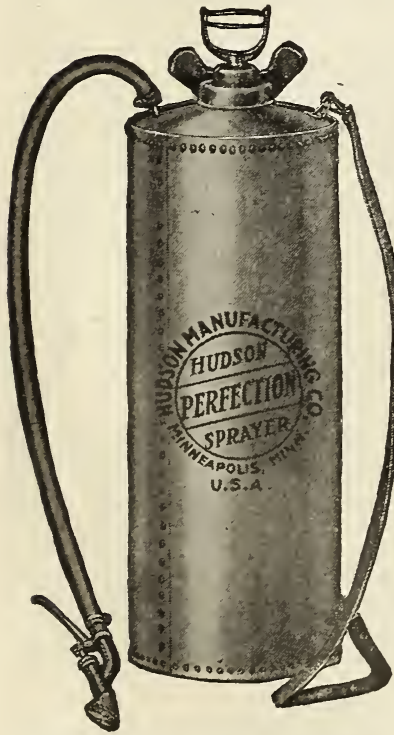

Perfection Compressed Air Sprayer Galv. $-2-3$ gal. $\$ 6.75$. Brass $\$ 875$

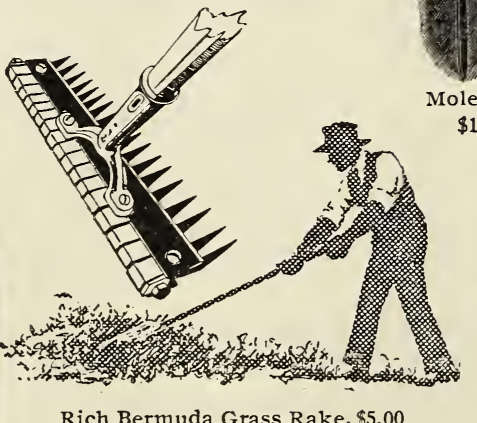

Rich Bermuda Grass Rake. $\$ 5.00$
Rich Lawn Comb..... 3.00

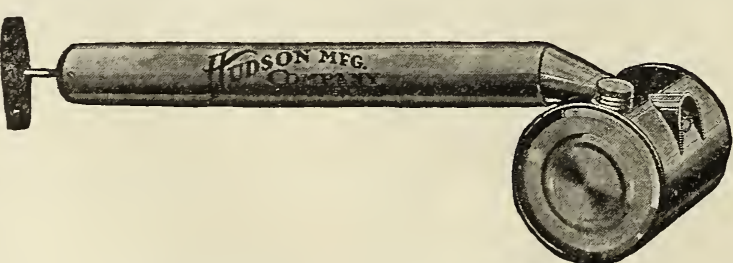

IIand Sprayers. Pint size $45 \mathrm{c}$; quart $65 \mathrm{c}$

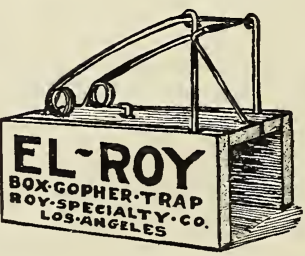

Roy Box Gopher Trap, 35c

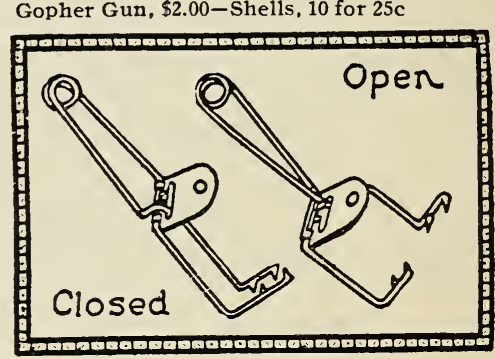

Roy Gopher Trap, 25c

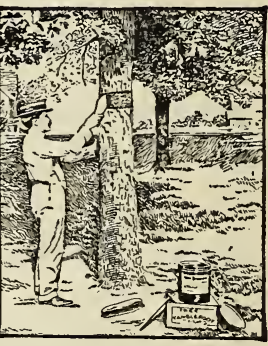

Tree Tanglefoot

Keeps the scale carrying A gentine Ant out of fruit an other trees.

11 b. 60 c; 51 bs. $\$ 2.75$

Write us regarding supplies for the garden

If you have friends whom you think would be interested in this catalog, send us their names and we will mail them a copy, gladly. Or if you are ever in need of advice or help regarding your garden problems, write us - our thirty-two years experience in Southern California is yours for the asking, anytime. 


\section{THEODORE PAYNE \\ 345 SOUTH MAIN STREET \\ LOS ANGELES. CAL.}

YOUR NAME

WRITE PLAINLY. STATE MRS. MR. OR MISS

STREET OR RURAL DELIVERY

POSTOFFICE

STATION OR EXPRESS OFFICE
COUNTY

$\begin{aligned} & \text { Check X Xow } \\ & \text { you wish this } \\ & \text { order sent }\end{aligned}$ Parcel Post
Express
Freight

AMOUNT ENCLOSED

Momey Order \$

Stamps

Check

Cash

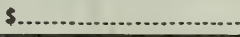

(DO NOT WRITE IN THIS SPACE)

Amt Recd

Date Reed.

Reg No

Filled by

Date Shipped.

$\mathrm{B} / \mathrm{O} \mathrm{By}$.

\section{PLEASE READ BEFORE ORDERING}

PACKING CHARGE. Add $15 \%$ of the amount of your order for actual cost of packing; minimum charge of $25 \mathrm{c}$ on all plant or tree orders.

SHIPPING.' All orders for plants or trees forwarded at purchaser's expense and risk. We do not ship orders of less than one dollar and in no instance will plants or trees be sent C. O. D. Inspection Certificate is attached to each order, Insuring the purchaser of clean, healthy stock.

NON.WARRANTY. Theodore Payne gives no warranty, express or implied, as to the purity, description, quality, productlve. ness or any other matter of any seeds, bulibs, plants or trees he sells and will not be in any way responsible for the crop.

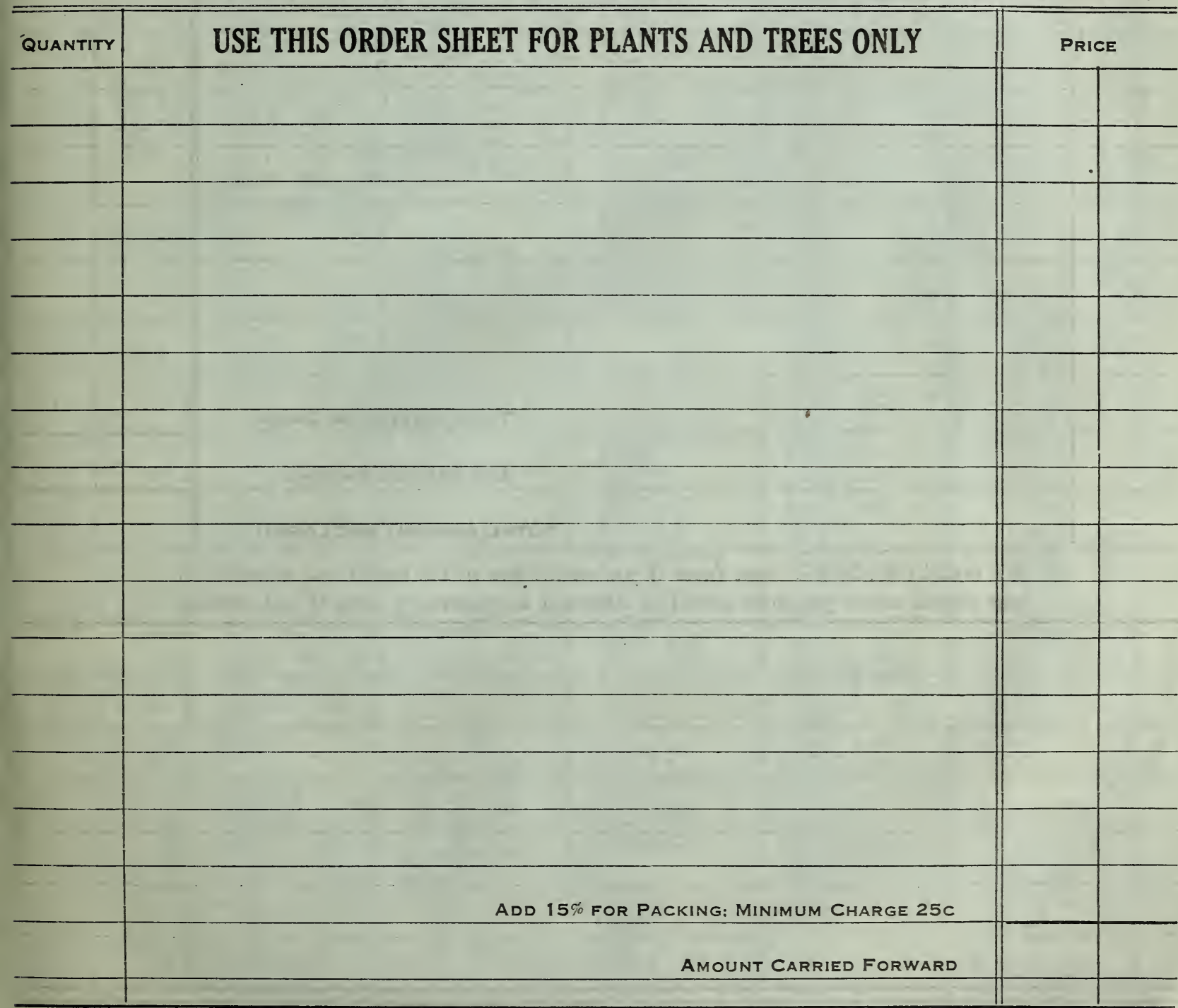




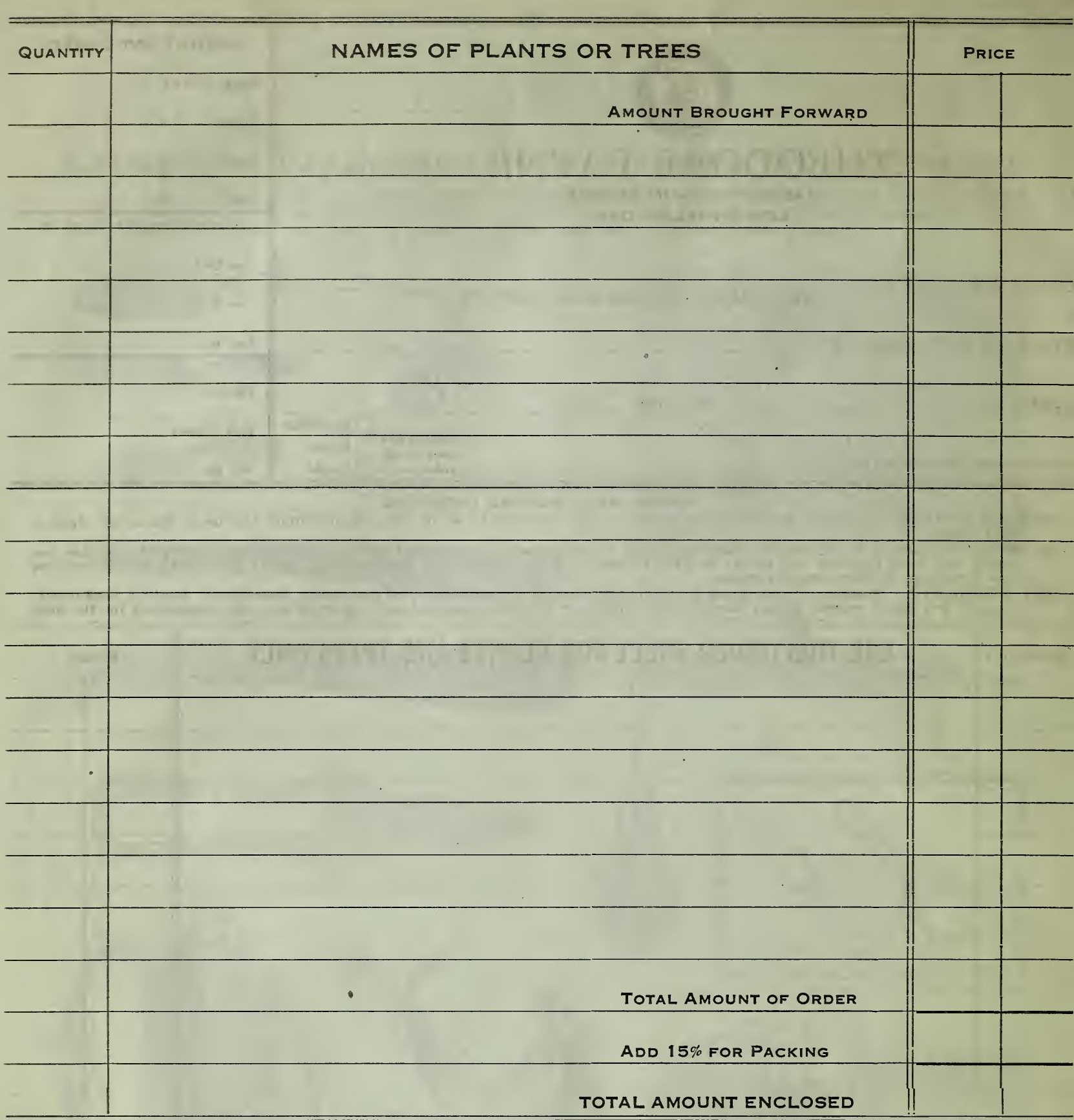

We would consider it a great favor if you would give us the names and addresses of your friends whom you think would be interested in receiving a copy of our catalog. 
INDEX TO DEPARTMENTS

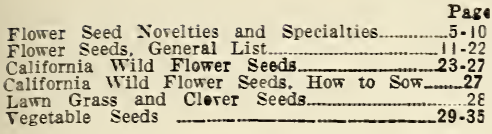

Pase

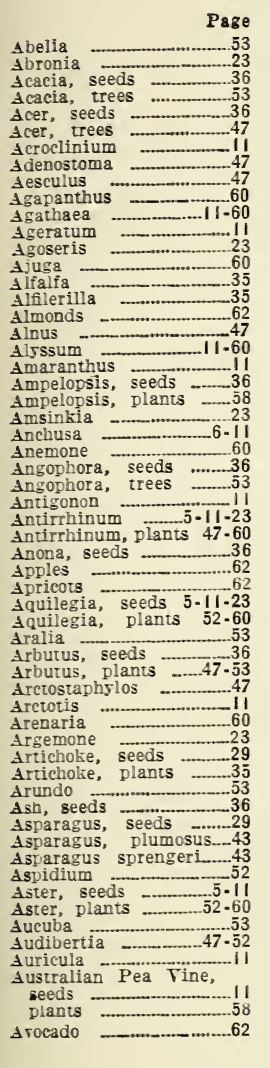

Baer1a
Balsam

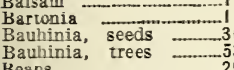

Beans

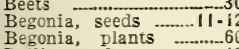

Bellis, seeds.

Bellis, plants

Berberis, seeds $-\ldots . . .37$
Berberis, plants

Berberis, plants $47-53$
Bermuda Grass Rake....6-

Bidens
Bignonia
Bilbergi

Blackberries
Blue Bonnets

Bougainrillea
Brachiscome

Brachiscome
Broom, seeds

Broom, seeds
Brom, plants
Browallia

Brussels sprouts.........

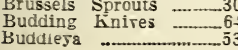

Cabbage, seeds
Cabbage, plants

Cabbage, plants
Cactus

Cactus $\quad-\quad-\quad 6$

Calendula, seeds
Calendula, plants $\ldots-. .6-12$

California Wild Flower

Seeds, Soureni
Collection

California Wild Flower

California Wild Flower

Seeds; How to Sow -27

California Wild

$-27$

California Native 4 47-52
Plants

Calandrina $\quad-\quad$
Calla $\quad-\quad 23$
C

Calla _.........

Callistemon, plants _.....
Calliopsis
Callitris ..........

Campanthu

Cassia, plants …_.
Castilleja
Casuarina, seeds …-...3

Casuarina, seeds
Casuarina, trees …....

Caulfilower, seeds
Cauliflower, plants -...
Ceanothus, plants

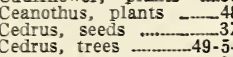

Celosia

Centaurea, seeds....
Centaurea, plants...
Cephalanthus

Chrrsanthemum,

seeds

Circium, seeds

Cistus
Clarkia obaea

Coccs, seeds

Coronilla, seeds

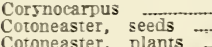

Cress Myr Cynoglossum, seeds
Cynoglossum, plants Dahlia, seeds Dandelion

Dendromecon,

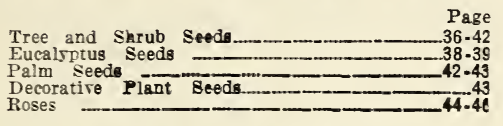

GENERAL INDEX

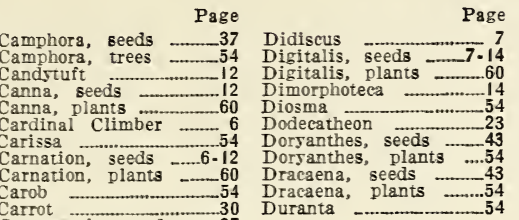

Carpenteria, seeds

Cassia, seeds ………...37

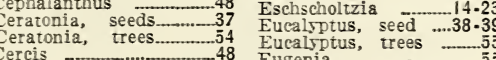

Cercocarpus $\ldots \ldots$

Chamaecyparis, trees....48

Chamaerops, seeds ....... 42 Feijos

Chayote … trees - - -34 Festuca

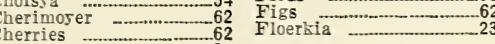

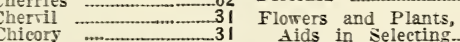

Chinese Wool Flower.. $\begin{array}{lll}\text { Chorizema, seeds } & \ldots .37 \\ \text { Chorizema, plants } \ldots . . .54\end{array}$

plants $1-60$

Cineraria, peeds $\ldots .6-13$

clematis ……………48-58

Climbing Plants $\quad-\quad-\quad 13$

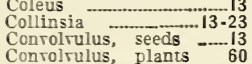

Fragaria, plants ...

Frasinus, seeds $\ldots-\ldots . \quad 23$

Frasinus, trees $\ldots . . .48$
Freesia
Fremontia, seeds …..... 40

Gaillardia

Garden Calender
Garden Tools...

Garrsa

Genista, seeds _... $\quad 40$ Lupinus, seeds $\ldots . .7 \cdot 16-2$

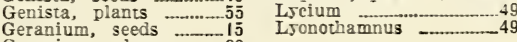

$\begin{array}{lr}\text { Conrolrulus, plants } & 60 \\ \text { Coprosma, seeds } & -37 \\ \text { Cong }\end{array}$

Gerbera, seeds

37 Geum, plants ……......60

Coreopsis, seeds $\ldots .13-23$

Gladiolus
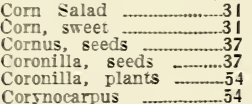

Cosmos

Crsptomeria
Cueumber

Cucumber, wild $\ldots . . .-._{14}^{3}$

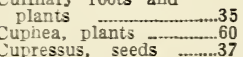
Cupressus, seeds $\ldots . . .37$
Cupressus, trees $\ldots . . .68-54$
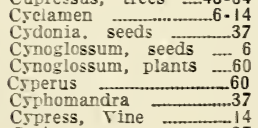
Crpress, vine $\ldots . .13$
Crstisus

aiss, seedsts .........59-60

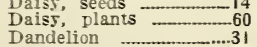

Delphinium,

seeds
Dlants $-\quad 6-7-14-23$

.23-37

seeds
plants
$-\quad-\quad . \quad 23-37$
$-\quad-18$

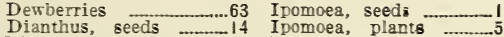

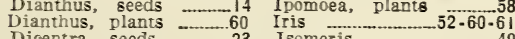

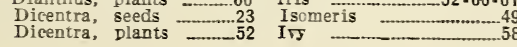

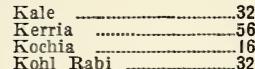

Lavin Comb a..........

Making
Lawn Fertilizers

Lawn
Lasia
Leek
Lemon

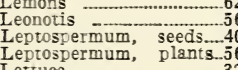

Leucadendron

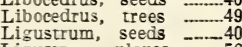

Ligustrum, plants

Linanthus $1-1-17-2$

Lobelia, seeds

Lobelia, plants $\ldots . . . . . . . . .6$
Logan Berrs

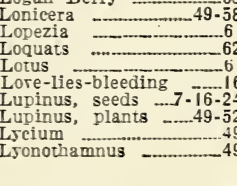

Magnolia, seeds...--40
Magnolia, trees..--56
Malacothrix

Mralrastrum -........

Manderillea, seeds
Manderillea, plants

Marticaria

Gomphrena Exterminator ...64

Gopher Traps ………....6

Grass
Grerillea, seeds
Grevillea,

Melia, seeds
Melon, Musk
Melon, Water

Melon, Water
Mentelia ...
Mesembrranthemum

seeds

Mletrosideros

Micromeria
Mignonette

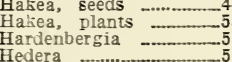

Helianthus

Heliotrope, seeds …15

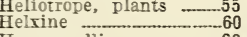

Hemerocallis

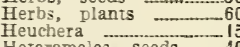

.

Hollshock, seeds _....... 15
Hoilshocks, plants .... 60

Horticultural Books ...63

Iyrtus, seeds

Nandina

Nasturtium

Ñemesia

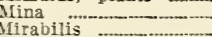

Hiscellaneous Flower-

Mromordica

Muehienbecki

Musa, seeds

Mushroom Spaw

ISosotis, seeds

Nicotiana, seeds $\ldots-17$

Nicotiana, seeds
Nicona, plants..- .49
Nierembergis $\quad-. .49$
Nigelia
Fremontia, plants.-- .5
Fuchsia
Furcraea
-

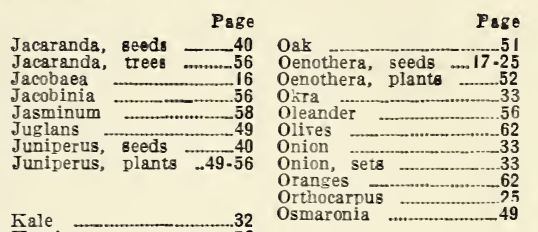

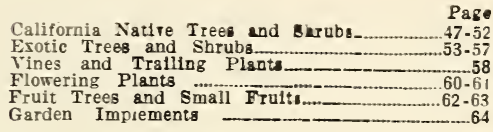

Phoormium, seed

Horseradish

Mimulus, seeds $-\ldots 17-2$

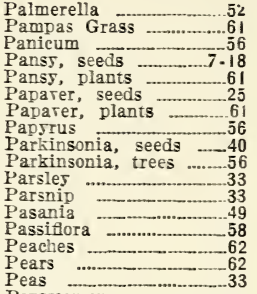

Pentstemon, $\quad 19-25.2$
seeds

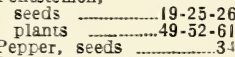

Pepper, seeds
Pepper, plants
Pepper Tree, seeds -
Pepper Tree, plants

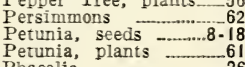

Phacelia

Phlox, seeds
Phlox, plants

Phormium, plants $-\begin{array}{r}-43 \\ -5\end{array}$

Picea
Pinus, seeds $\quad-\quad-\quad 41$
Pinus, trees $-\quad .50-56$

Pistachio
Pittosporum, seeds -5
Pittosporum, trees -5
Platanus

Platanus

Platrstemo
Plumbago

Plums
Podocarpus
Poinsettia

Poiranthus

Polsgon
Pomelo
Popps
Populus

Portulaca
Potatoes

Potentilila

Primula, seeds

Priret, seeds

Prunes $1 .-1 . .63$

Pruning shears $-. . .6-64$
Prunus, seeds
P...

Prunus, trees

Psidium, seeds …… 41
Pteris

$\begin{array}{lr}\text { Pumpkin } & -34 \\ \text { Punica } & -57 \\ \text { Pyracantha, seeds } & -54 \\ \text { Pyracantha, plants } & -5 .-57\end{array}$

Pyracantha, plants --57
Pyrethrum $-\ldots .5$

Quercus $\quad-\quad 51$

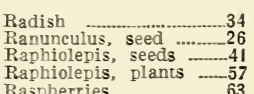

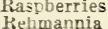

Khamnus

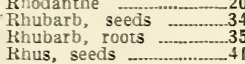

Rhus, seeds
khus, plants

Ricinus
Kobinia

Robini
Rochea

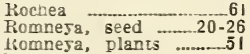

\section{Rosa}

\begin{tabular}{l} 
Roselle \\
Rosemarinus …… $\quad 34$ \\
\hline
\end{tabular}$-57$

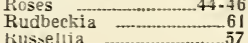

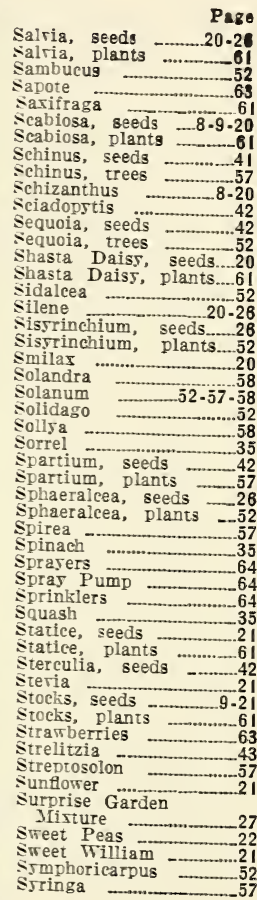

Tacsonia, seeds ….... 2

Tagetes
Tanglefoot
Teco-n...-...-. -1.64

Thalictrum, seeds
Thalictrum, plants
$52-61$

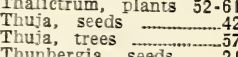

Thunbergia, seeds $-y_{2}^{57}$
Thunbergia, plants $-\sim^{6}$

Tithonia seeds ……- - 35

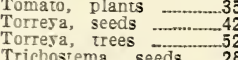

Trichostema, plants .......52

ristania, strees ……-. 57

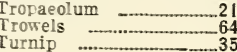

Cles, seeds $\ldots$

Tmbrella Tree, seeds_.42

Fegetable Plants $\quad-\quad 61$

Verbascum
Yerbena, seeds $\ldots \ldots-. \quad 2$

Terbesina

Tiburnum, seeds $\ldots \ldots . .4$
Tiburnum, plants $\ldots . .5$

Vinca, seeds

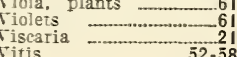

Wallfower, seeds ....9-2

Walnut -63
Washingtonia $-\quad-\quad 63$

Wigandis - $-{ }^{4}$

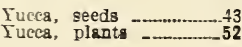

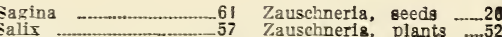

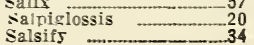

Zauschneris, plants $\ldots . .52$

Zinnia, plants …......
Wistaria, plants $-\mathbf{H}_{-58}$
Woodrardia 
